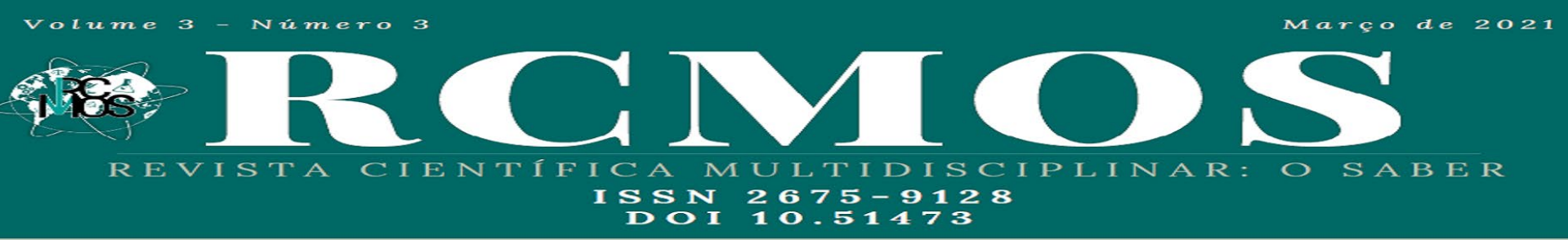

\title{
A atuação das forças armadas na segurança pública
}

The role of the armed forces in public security

\author{
PAVÉGLIO, Rafaele ${ }^{1}$
}

\section{Resumo}

O presente artigo tem como tema a atuação das Forças Armadas na Segurança Pública, com ênfase à forma como a Segurança Pública no Brasil vem sendo conduzida e delegada para as Forças Armadas, buscando responder à questão problema: as Forças Armadas possuem a finalidade de assegurar a segurança pública no Estado Democrático de Direito? Para tanto partiu-se da hipótese de que a atuação das Forças Armadas em atividade privativa das polícias militares dos estados viola a Constituição Federal de 1988. Neste contexto, a principal justificativa para o desenvolvimento da pesquisa sobre o tema proposto é o constante chamado das Forças Armadas para atuar na segurança pública, uma vez que se tem verificado que os governos estaduais, muitas vezes, omissos em relação à atuação das polícias militares e diante do crescimento desenfreado da criminalidade e da pressão da sociedade, os levam a solicitar ao Poder Executivo federal o auxílio do Exército. Em consequência se tem o enfraquecimento de ambas as instituições, e, ainda, a ocorrência de uma inversão de competências das forças amadas e das policias militares dos estados. O objetivo geral deste estudo é analisar o emprego das Forças Armadas na garantia da lei e da ordem em momentos de extrema crise na segurança pública. Para tanto desenvolveu-se uma pesquisa de metodologia bibliográfica, tendo como base a Constituição Federal Brasileira de 1988, e autores como Celso Antônio Bandeira De Mello (2009); Maria Sylvia Zanella di Pietro (2014); Emerson Garcia (2009); Helly Lopes Meirelles (2009), dentre outros que discutem o assunto.

Palavras-chave: Forças Armadas. Legitimidade. Poder de polícia. Segurança Pública.

\section{Introdução}

Este artigo foi desenvolvido sobre o tema a atuação das Forças Armadas na segurança pública. O objetivo principal é estudar sobre a atuação reiterada das Forças Armadas na segurança pública para compreender se realmente há esta possibilidade, e se a Marinha, Exército e Aeronáutica, podem atuar para a manutenção da ordem e da lei e combater à criminalidade nos Estados-membros, por exemplo.

A Segurança Pública do Estado destina-se a um serviço prestado com a finalidade de assegurar o convívio harmônico e social da sociedade. Aparentemente, as Forças Armadas ao patrulharem ruas, avenidas e bairros inverte a ordem cronológica do mandamento constitucional, atuando como poder polícia, já que o patrulhamento ostensivo é competência exclusiva das Polícias Militares. Diante disso, pergunta-se: Possuem as Forças Armadas a

1 Especialista em Gestão em Sistemas Prisionais. Instituto Brasil de Ensino - IBRA. E-mail: rafaele.paveglio@bol.com

RCMOS - Revista Científica Multidisciplinar O Saber. ISSN: 2675-9128. DOI 10.51473. São Paulo, v. 03, p. 01-14, mar. 2021. 


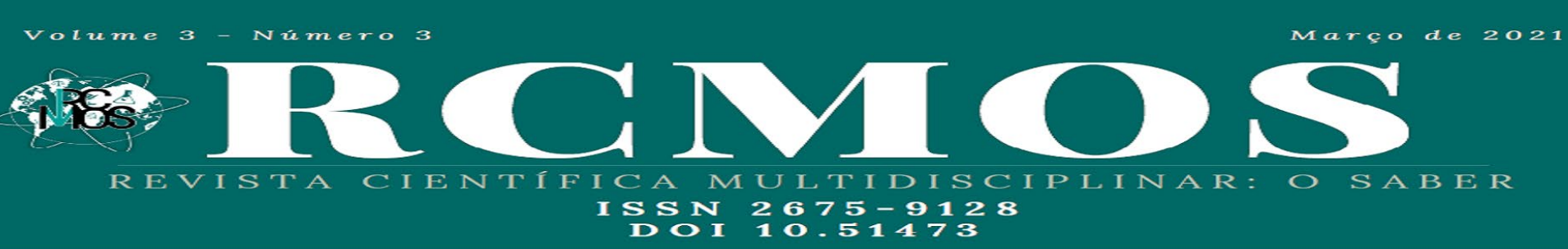

finalidade de assegurar a segurança pública no Estado Democrático de Direito? A segurança pública garantida constitucionalmente no artigo 144, caput da Constituição da República Federativa do Brasil, destina-se a um serviço prestado com a finalidade de assegurar o convívio harmônico e social da sociedade, o qual é direito de todos, e responsabilidade do Estado, devendo ser exercida a preservação da ordem pública e da incolumidade das pessoas e do patrimônio.

A própria Constituição Federal de 1988, relacionou os órgãos encarregados dessa missão: no âmbito federal, a Polícia Federal, a Polícia Rodoviária Federal e a Polícia Ferroviária Federal e no âmbito estadual, as polícias civis e militares e os corpos de bombeiros militares. Observa-se que não consta nesta enumeração as Forças Armadas. A segurança pública enquanto dever do Estado e, direito e responsabilidade de todos, vem sendo discutida incessantemente pela sociedade, principalmente, em relação à atuação dos órgãos encarregados de agir para proteger todos os cidadãos.

Neste contexto, este estudo apresenta relevância, sobretudo em função do constante chamado das Forças Armadas para atuar na segurança pública, uma vez que se tem verificado que os governos estaduais, muitas vezes, omissos em relação a atuação das polícias militares e diante do crescimento desenfreado da criminalidade e da pressão da sociedade, acabam solicitando ao Poder Executivo Federal o auxílio do Exército.

Com relação à metodologia utilizada para a realização desta pesquisa adotou-se o método de abordagem hipotético-dedutivo, com a utilização no seu delineamento da coleta de dados em fontes bibliográficas disponíveis em meios físicos e na rede de computadores, para ao final realizar a exposição dos resultados obtidos através de um texto descritivo.

\section{Fundamentação teórica}

2.1 Poder de polícia na ordem constitucional e sua organização estatal

Em um primeiro momento, há a necessidade de entender a importância de a Administração Pública agir em conformidade com a Lei, uma vez que sua atuação deve se dar como expressamente delimitados, ou seja, dentro da legalidade. Para esta abordagem utilizouse autores como Celso Antônio Bandeira de Mello (2009) e de Maria Sylvia Zanella Di Pietro (2014). Inicialmente aborda-se a questão do poder de polícia, sendo que para um melhor entendimento, citam-se conceitos, características e aspectos relevantes. No que se refere à estruturação estatal, é considerada a ordem constitucional e como ocorre sua organização.

RCMOS - Revista Científica Multidisciplinar O Saber. ISSN: 2675-9128. DOI 10.51473. São Paulo, v. 03, p. 01-14, mar. 2021. 


\section{Votume 3 - Número 3

O poder de polícia serve como meio de controle, um freio no tecido social, sustentado por um aparato regulado por Leis, Regulamentos, Códigos entre outros. Servindo para o bemestar e segurança de todos. Segundo Maria Silvia Zanela Di Pietro (2014, p. 125) afirma:

[...] o poder de polícia no Estado, poderá incidir em duas áreas de atuação estatal: (estamos referindo ao Estado, porque é o foco de nossa pesquisa quando questionamos a atuação das forças Armadas para fazer o papel de Polícia no Estado) a) na área administrativa; b) na área judiciária.

Neste sentido ela estabelece um conceito de Poder de Polícia e a diferença entre ambos:

[...] a Polícia Judiciária é privativa de corporações especializadas (polícia civil e militar), enquanto a Polícia Administrativa se reparte entre diversos órgãos da administração, incluindo, além da própria Polícia Militar, os vários órgãos de fiscalização aos quais a lei atribui esse mister, como os que atuam nas áreas da saúde, educação, trabalho, previdência e assistência social (DI PIETRO, 2014, p. 126).

Deve-se considerar que o poder de polícia exercido pela polícia judiciária refere-se aos policiais militares no momento de sua atuação. É importante destacar que o conceito legal de Poder de Polícia encontra-se no art. 78 do Código Tributário Nacional (BRASIL, 1966), pois o exercício de poder de polícia representa uma hipótese de incidência tributária, no caso, a cobrança de uma taxa, que considera este como sendo:

[...] a atividade da administração pública que, limitando ou disciplinando direito, interesse ou liberdade, regula a prática de ato ou abstenção de fato, em razão de interesse público concernente à segurança, à higiene, à ordem, aos costumes, à disciplina da produção e do mercado, ao exercício de atividades econômicas dependentes de concessão ou autorização do Poder Público, à tranquilidade pública ou ao respeito à propriedade $\mathrm{e}$ aos direitos individuais ou coletivos.

Nesta mesma linha de raciocínio Hely Lopes Meirelles, apresenta o Poder de Polícia como:

O mecanismo de frenagem de que dispõe a Administração Pública para conter os abusos do direito individual. Por esse mecanismo, que faz parte de toda a Administração. O Estado detém a atividade dos particulares que se revelar contrária, nociva ou inconveniente ao bem-estar social, ao desenvolvimento e à segurança nacional (MEIRELLES, 2000, p. 122).

Compreende-se que o poder de polícia está à disposição da Administração Pública, de modo que esta vise a consecução do interesse comum da coletividade, em prol dos administrados, conduzindo o Estado a agir em benefício da manutenção da ordem social e jurídica, para alcançar o bem estar coletivo. Com isso, constata-se que estudar as Forças Armadas é indispensável para compreender se essa instituição permanente é dotada de poder 


\section{Volume 3 - Número 3

de polícia, e se pode atuar em áreas de atribuição de outros órgãos. A violência policial, a repressão e a punição são algumas das diversas questões relacionadas à segurança pública, que tem ganhado destaque no mundo e no Brasil.

De acordo com a Constituição Federal, segurança pública é assunto de responsabilidade dos governos Federal e Estaduais, conforme refere no art.144 da Constituição Federal, caput: “Art. 144. A segurança pública, dever do Estado, direito e responsabilidade de todos, é exercida para a preservação da ordem pública e da incolumidade das pessoas e do patrimônio, através dos seguintes órgãos $[\ldots]$ "

Na sequência trata-se da formatação constitucional das Forças Armadas, destacando-se suas competências no ordenamento jurídico brasileiro e a distinção de concepção entre as polícias e as forças armadas.

\subsection{As forças armadas na Constituição da República}

A Constituição Federal de 1988 prescreve em seus arts. 142 e 143, onde está definido o tema respectivamente na sua forma literal, explicitando e limitando o poder de atuação das Forças Armadas, enquanto defensores da Pátria. Prerrogativa essa, de manter a ordem e zelar pelos ditames constitucionais em todo território nacional. É importante referir que o art. 142 da Constituição Federal, expressa os elementos constituintes das Forças Armadas, e estabelece sua função definindo que:

Art. 142. As Forças Armadas, constituídas pela Marinha, pelo Exército e pela Aeronáutica, são instituições nacionais permanentes e regulares, organizadas com base na hierarquia e na disciplina, sob a autoridade suprema do Presidente da República, e destinam-se à defesa da Pátria, à garantia dos poderes constitucionais e, por iniciativa de qualquer destes, da lei e da ordem (BRASIL, 1988).

Como se pode verificar, o artigo 142 prevê objetivamente o emprego das Forças Armadas em operações de segurança pública condicionado à requisição dos poderes constitucionais e sob a autoridade do Presidente da República.

Destacando-se que, sua participação nesse tipo de operações, somente pode ocorrer se forem requisitadas e autorizadas pelo chefe do executivo federal. Mesmo havendo a expressa possibilidade de utilização das Forças Armadas na garantia da lei e da ordem, o artigo 144 da Constituição Federal, indica que esse emprego deve se dar como último recurso de defesa dessas instituições. O já citado artigo do texto constitucional lista os órgãos que possuem a tarefa precípua de preservar a ordem pública: 


\section{Volume 3 - Número 3

Art. 144 - A segurança pública, dever do Estado, direito e responsabilidade de todos, é exercida para a preservação da ordem pública e da incolumidade das pessoas e do patrimônio, através dos seguintes órgãos:

I - Polícia federal;

II - Polícia rodoviária federal;

III - Polícia ferroviária federal;

IV - Polícias civis;

V - Polícias militares e corpos de bombeiros militares. (BRASIL, 1988).

Nesse contexto, foi editada a Lei Complementar n. 97, de 09 de junho de 1999, posteriormente alterada pela Lei Complementar n. 117, de 02 de setembro de 2004, que disciplina o emprego das tropas federais nas operações de garantia dos poderes constitucionais, da lei e da ordem, como medida excepcional.

Infere-se que o legislador, "ao atribuir às Tropas a responsabilidade pela garantia da lei e da ordem, retrata situações ímpares, evidenciadas pelo colapso no combate à criminalidade e diante do quadro de incapacidade ou de insuficiência operacional dos órgãos de segurança", destaca Andréa Costa Corrêa (2011).

As Forças Armadas garantem o desenvolvimento das atividades estatais contra as investidas de outros países, cabendo à Marinha de Guerra resguardar o espaço marítimo, à Aeronáutica zelar pela extensão aérea e ao Exército Brasileiro cuidar da dimensão terrestre (CORRÊA, 2011).

O poder de polícia conferido às Forças Armadas, segundo Corrêa (2011) “[...] não é a regra nas questões de segurança pública, revelando-se estas em situações especiais juridicamente previstas na lei." No entanto, o dispositivo é alvo de intensos debates, alguns sustentando a inconstitucionalidade do inciso IV, do artigo 17-A, incluído pela Lei Complementar n. 117, de 2004, sob o argumento de que a prevenção e a repressão de crimes de faixa de fronteira, assim como os delitos ambientais, cabem exclusivamente à Polícia Federal, por determinação expressa da Constituição (CORRÊA, 2011). Ao tratar do assunto, leciona João Rodrigues Arruda (2007, p. 104) que:

\footnotetext{
Mesmo sendo o Presidente da República a autoridade que detém o poder de polícia federal no mais alto nível e também o comandante-em-chefe das Forças Armadas, não pode ele transferir as atribuições de uma para outras das instituições. Nem o Congresso Nacional pode fazê-lo. A barreira intransponível é a Constituição, que fixou as missões que cabem a cada uma delas. As Forças Armadas no artigo 142 e a Polícia Federal no artigo 144 (ARRUDA, 2007, p. 104).
}

$\mathrm{Na}$ verdade, o que está afirmando é que o Presidente da República mesmo sendo a autoridade máxima do Estado brasileiro e sendo o Comandante das Forças Armadas deve ter 


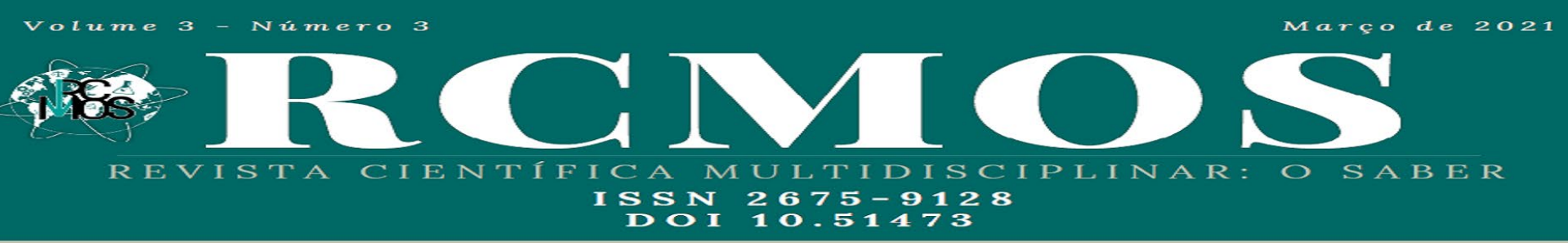

muito cuidado ao fixar missões para o Exército, marinha ou Aeronáutica, pois quem determina as competências de cada uma das instituições citadas é a própria Constituição Federal de 1998 e somente por meio de Emenda à Constituição poderá ser ampliada.

Por isso, há a necessidade de se conhecer sobre as competências das Forças Armadas e procurar entender a participação do Exército nas ações de segurança pública dos Estados federados.

\subsubsection{As competências das Forças Armadas no ordenamento jurídico brasileiro}

Há que se considerar que a existência das Forças Armadas na Constituição Federal de 1988, como uma instituição permanente e regular, tem sua razão de ser, principalmente se se souber compreender sua forma de atuação na sociedade. Neste sentido, os esclarecimentos de Emerson Garcia (2009, p.46) são fundamentais. Veja-se:

A forma de atuação das Forças Armadas está relacionada ao cumprimento de obrigações internacionais de natureza militares assumidas pelo País, que podem derivar imediatamente de tratados ou convenções internacionais de natureza bilateral ou multilateral ou decorrer de deliberações adotadas por alguma organização internacional de que faça parte. É nesse último contexto que se inserem as operações de manutenção da paz mantidas pela Organização das Nações Unidas, utilizadas com frequência apesar da ausência de qualquer referência na Carta da ONU GARCIA, 2009, p. 46).

Analisando o exposto pode-se referir que é nesse último contexto que se inserem as operações de manutenção da paz mantidas pela Organização das Nações Unidas, utilizadas com frequência, apesar da ausência de qualquer referência na Carta da ONU, sustenta Emerson Garcia (2009) ao referir-se sobre a atuação da Marinha, Exército e Aeronáutica.

O primeiro dever de qualquer governo é a defesa da paz, que deve ser compreendida em seu sentido lato, abrangendo tanto a paz interior, como a paz exterior. A análise das situações de risco e do status do opressor permite afirmar que as Forças Armadas possuem quatro objetivos fundamentais, conforme indica Emerson Garcia (2009):

1) Defender a soberania brasileira, garantindo suas fronteiras e reprimindo o inimigo externo;

2) Atuar no cumprimento das obrigações internacionais, de caráter militar, assumidas pelo País;

3) Defender a ordem interna em situações de anormalidade institucional;

4) Defender a ordem interna em situações de normalidade institucional (GARCIA, 2009, p. 51). 


\section{Volume 3 - Número 3

Partindo do que foi exposto, percebe-se que em primeiro lugar as Forças Armadas têm o dever de atuar em defesa da paz interna e externa do País, no entanto, se ocorrer situações de anormalidade que estão colocando em risco a sociedade, aí sim, poderão ser deslocados da sua função principal.

Manoel Gonçalves Ferreira Filho (2002, p. 235) conceitua as Forças Armadas como "um corpo especial da Administração Pública, oposto ao setor civil por sua militarização, pelo enquadramento hierárquico de seus membros em unidades armadas e preparadas para o combate." As Forças Armadas têm como finalidade precípua a garantia da segurança Externa do Estado, e também dos poderes constitucionais, aí compreendidos o Executivo, o Legislativo e o Judiciário, razão por que detêm a concentração do poderio bélico. Somente em situações extremas é que atuarão na segurança da lei e da ordem interna.

A Constituição estabelece que as Forças Armadas devem defender o país contra agressões estrangeiras em caso de guerra externa, e também as instituições democráticas, visando à garantia dos poderes constitucionais emanantes do povo (SILVA, 2004).

As funções precípuas dessa Instituição são a defesa da Pátria, a garantia dos poderes constitucionais, da lei e da ordem. As normas gerais a serem adotadas na organização, no preparo e no emprego das Forças Armadas são estabelecidas pelo Decreto n. 88.777, de 30 de setembro de 1983, que aprova o regulamento para as polícias militares e corpos de bombeiros militares (R-200); pela Lei Complementar n. 97, de 9 de junho de 1999, alterada pela Lei Complementar n. 117, de 02 de setembro de 2004, que dispõe sobre as normas gerais para a organização, o preparo e o emprego das Forças Armadas, e o Decreto n. 3.897, de 24 de agosto de 2001, que fixa as diretrizes para o emprego das Forças Armadas na garantia da lei e da ordem (GARCIA, 2009).

A LC n. 97/99 normatiza os requisitos e condições de atuação das Forças Armadas, cuja decisão de iniciar a execução das medidas consideradas necessárias à defesa da lei e da ordem é de competência e responsabilidade do Presidente da República. Estes preceitos se depreendem da leitura do extenso artigo 15, da LC n. 97/99 que será desmembrado para ficar mais claro sobre o tema que se está abordando, qual seja, as competências assim dispostas na referida Lei. Assim dispõe:

Art. 15. O emprego das Forças Armadas na defesa da Pátria e na garantia dos poderes constitucionais, da lei e da ordem, e na participação em operações de paz, é de responsabilidade do Presidente da República, que determinará ao Ministro de Estado da Defesa a ativação de órgãos operacionais, 


\section{Volume 3 - Número 3

\section{[...]}

$\S 1$ o Compete ao Presidente da República a decisão do emprego das Forças Armadas, por iniciativa própria ou em atendimento a pedido manifestado por quaisquer dos poderes constitucionais, por intermédio dos Presidentes do Supremo Tribunal Federal, do Senado Federal ou da Câmara dos Deputados (BRASIL, 1999, Redação dada pela Lei Complementar $n^{\circ} 136$, de 2010).

Evidencia-se nesta primeira parte que as Forças Armadas têm a competência precípua de atuação na defesa da Pátria e na garantia dos poderes constitucionais, da lei e da ordem, e na participação em operações de paz; mas que compete ao Presidente da República a decisão do emprego das Forças Armadas na garantia da lei e da ordem, principalmente, quando a preservação da ordem pública e da incolumidade das pessoas e do patrimônio está sofrendo ameaças ou tem sido atacada constantemente. Conforme o expresso no artigo 15, da LC n. 97/99, reforçado pelo seu $\S 1^{\circ}$, constata-se que cabe ao Presidente da República, na qualidade da autoridade hierárquica suprema, a responsabilidade pela decisão de empregar as tropas no combate da violência civil, mesmo nas hipóteses de atenção a pedido expresso de quaisquer dos Poderes Constituídos, seja do presidente do Supremo Tribunal Federal ou dos presidentes das casas do Congresso Nacional.

O emprego das Forças Armadas está autorizado, nos termos da legislação de regência, desde que fique caracterizado o esgotamento dos instrumentos "destinados à preservação da ordem pública" (Lei Complementar $n^{\circ}$ 97/99, art. 15, $\S 2^{\circ}$ ). Devendo, para tanto, serem considerados esgotados os instrumentos relacionados no art. 144 da Constituição Federal quando, “[...] em determinado momento, forem eles formalmente reconhecidos pelo respectivo Chefe do Poder Executivo Federal ou Estadual como indisponíveis, inexistentes ou insuficientes ao desempenho regular de sua missão constitucional" (BRASIL, 1999, Lei Complementar $n^{\circ}$ 97/99, art. 15, $\S 3^{\circ}$ ). Da mesma forma, pode-se dizer que as Forças Armadas, conforme o $\S 4^{\circ}$, do art. 13, dispõe:

Na hipótese de emprego nas condições previstas no § 3o deste artigo, após mensagem do Presidente da República, serão ativados os órgãos operacionais das Forças Armadas, que desenvolverão, de forma episódica, em área previamente estabelecida e por tempo limitado, as ações de caráter preventivo e repressivo necessárias para assegurar o resultado das operações na garantia da lei e da ordem (BRASIL, 1999, Redação dada pela Lei Complementar no 136 , de 2010).

Denota-se que está claro que o Chefe da República baixará as diretrizes mediante mensagem de ativação dos órgãos operacionais das Forças Armadas, traçando as ações de caráter preventivo e repressivo necessárias para assegurar o resultado das operações na garantida da lei e da ordem. A atuação das forças federais não será um evento autônomo, mas 


\title{
Votume 3 - Número 3

$\S 5^{\circ}$ Determinado o emprego das Forças Armadas na garantia da lei e da ordem, caberá à autoridade competente, mediante ato formal, transferir o controle operacional dos órgãos de segurança pública necessários ao desenvolvimento das ações para a autoridade encarregada das operações, a qual deverá constituir um centro de coordenação de operações, composto por representantes dos órgãos públicos sob seu controle operacional ou com interesses afins (BRASIL, 1999, Redação dada pela Lei Complementar $\mathrm{n}^{\mathrm{o}} 136$, de 2010).

O controle operacional dos órgãos de segurança pública será transferido ao Presidente da República, que constituirá um centro de coordenação das operações necessárias à execução da garantia da lei e da ordem pública, composto por representantes dos demais órgãos públicos. Sendo que o $\S 6^{\circ}$ do artigo 15 da LC 97/99, sustenta que:

Considera-se controle operacional, para fins de aplicação desta Lei Complementar, o poder conferido à autoridade encarregada das operações, para atribuir e coordenar missões ou tarefas específicas a serem desempenhadas por efetivos dos órgãos de segurança pública, obedecidas as suas competências constitucionais ou legais. $\S 7$ o A atuação do militar nos casos previstos nos arts. 13, 14, 15, 16-A, nos incisos IV e V do art. 17, no inciso III do art. 17-A, nos incisos VI e VII do art. 18, nas atividades de defesa civil a que se refere o art. 16 desta Lei Complementar e no inciso XIV do art. 23 da Lei no 4.737, de 15 de julho de 1965 (Código Eleitoral), é considerada atividade militar para os fins do art. 124 da Constituição Federal. (BRASIL, 1999, Redação dada pela Lei Complementar nº 136, de 2010).

No artigo 16, da LC n. 97/99, o legislador determina que a missão das Forças Armadas seja de natureza subsidiária, na qualidade de colaboradoras do desenvolvimento nacional e da defesa civil. Nesse sentido, José Afonso da Silva (1999, p. 746) argumenta que:

\begin{abstract}
Só subsidiariamente e eventualmente lhes incumbe a defesa da lei e da ordem, porque essa defesa é de competência primária das forças de segurança pública, que compreendem a polícia federal e as polícias civil e militar dos Estados e do Distrito Federal. Sua interferência na defesa da lei e da ordem depende, além do mais, de convocação dos legitimados representantes de qualquer dos poderes federais: Presidente da Mesa do Congresso Nacional, República da República ou Presidente do Supremo Tribunal Federal. Ministro não é poder constitucional. Juiz de Direito não é poder constitucional. Juiz Federal não é poder constitucional. Deputado não é poder constitucional. Senador não é poder constitucional. São simples membros dos poderes e não os representam. Portanto, a atuação das Forças Armadas convocada por Juiz de direito ou por Juiz Federal, ou mesmo por algum Ministro do Superior tribunal de Justiça ou até mesmo do Ministro do Supremo Tribunal Federal, é inconstitucional e arbitrária, porque estas autoridades, por mais importantes que sejam, não representam qualquer dos poderes constitucionais federais.
\end{abstract}

Pode-se verificar que as Forças Armadas estão constitucionalmente designadas para defender a lei e a ordem, o que pode ser interpretado como uma autorização legal para atuar na "defesa interna".

Quanto à atuação em situações de normalidade, os requisitos foram estabelecidos em legislação infraconstitucional e por meio de regulamentação, como já mencionado RCMOS - Revista Científica Multidisciplinar O Saber. ISSN: 2675-9128. DOI 10.51473. São Paulo, v. 03, p. 01-14, mar. 2021. 


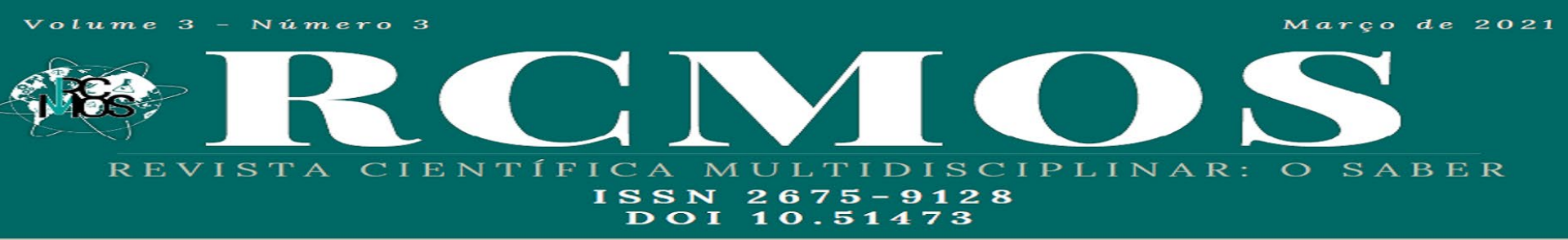

sociedade, deve sim, contribuir para que os governadores percebam que esse tipo de medida não soluciona os problemas existentes, ou seja, o combate à criminalidade violência, passa necessariamente por políticas públicas de inclusão social, nas quais se incluem a educação. Ao que se conclui que, em situações emergenciais e graves, que indiquem a necessidade de fortalecimento das instituições democráticas, é válido se recorrer ao auxílio das Forças Armadas, sem que isso consubstancie em violação dos princípios da Constituição Federal brasileira, já que a segurança pública é uma das garantias do Estado democrático de direito, que tem como sustentáculo as liberdades civis e a integridade dos cidadãos.

\section{Referências}

ARRUDA, J. R. O uso político das Forças Armadas. Rio de janeiro: Mauad X, 2007.

BRASIL. Lei 5.172, de 25 de out. de 1966. Dispõe sobre o Sistema Tributário Nacional e institui normas gerais de direito tributário aplicáveis à União, Estados e Municípios. Diário Oficial, Brasília, p. 12452, 25 out. 1966.

BRASIL. Constituição da República Federativa do Brasil. Brasília: Senado, 1988.

BRASIL. Lei Complementar n. 97/99. Brasília, DF: Senado, 1999.

BRASIL. Decreto n. 3.897, de 24 de agosto 2001. Fixa as diretrizes para o emprego das Forças Armadas na garantia da lei e da ordem, e dá outras providências. Brasília, DF, 24 ago. 2021. Disponível em: http://www.planalto.gov.br/ccivil_03/decreto/2001/D3897.htm. Acesso: 15 mar. 2021.

BRASIL. Lei Complementar n. 117, de 2 de setembro de 2004. Altera a Lei Complementar $n^{\circ}$ 9, de 9 de junho de 1999 que dispõe sobre as normas gerais para organização, 0 preparo e o emprego das Forças Armadas, para estabelecer novas atribuições subsidiárias. Diário Oficial da República Federativa do Brasil, Brasília, DF, 03 set. 2004.

BRASIL. Ministério da Defesa. Estado e Defesa. Brasília, 2021. Disponível em: http://www.defesa.gov.br/forcas-armadas. Acesso: 15 mar. 2021.

BRASIL. Polícia Militar do Paraná. Polícia: funções, atividades e características. Paraná, [2021]. Disponível em:

http://www.pmpr.pr.gov.br/modules/conteudo/conteudo.php?conteudo=665. Acesso: 15 mar. 2021.

CORRÊA, A. C. O poder de polícia das Forças Armadas no exercício da segurança pública. Revista Jus Navigandi, ISSN 1518-4862, Teresina, ano 16, n. 2771, 1 fev. 2011. Disponível em: https://jus.com.br/artigos/18396. Acesso: 15 mar. 2021.

DI PIETRO, M. S. Z. Direito administrativo. 27. ed. São Paulo: Atlas S.A, 2014. 


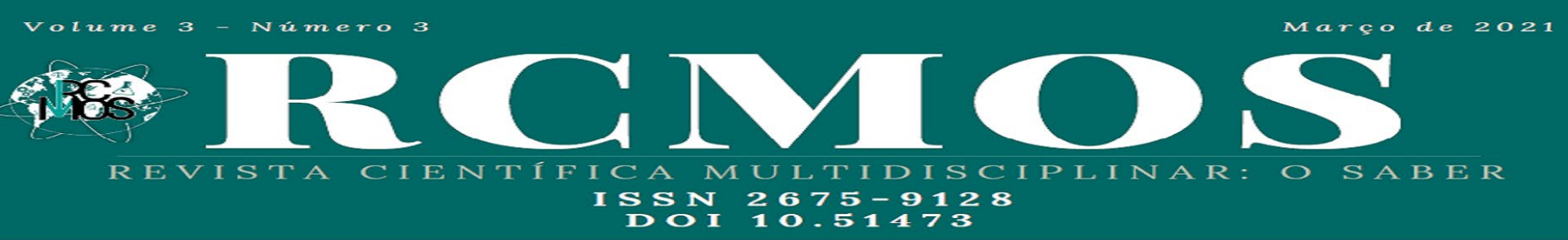

FERREIRA FILHO, M. G. Curso de Direito Administrativo. 28. ed. São Paulo: Saraiva, 2002 .

GARCIA, E. As Forças Armadas e a garantia da lei e da ordem. Revista Brasileira de Direito Constitucional - RBDC n. 13, jan./jun. 2009. Disponível em http://www.esdc.com.br/seer/index.php/rbdc/article/view/141/135. Acesso: 15 mar. 2021.

LOPES, H. R.; LEMOS, N. S. Aspectos constitucionais da segurança pública. In: Âmbito Jurídico, Rio Grande, XIV, n. 93, out. 2011. Disponível em: http://www.ambitojuridico.com.br/site/?n_link=revista_artigos_leitura\&artigo_id $=10490 \&$ revista_caderno $=9$. Acesso: 15 mar. 2021.

MELlO, C. A. B. de. Curso de Direito Administrativo. 26. ed. São Paulo: Malheiros, 2008.

MEIRELLES, H. L. Direito Administrativo brasileiro. 35. ed. São Paulo: Malheiros Editores Ltda, 2010.

SILVA, B. T. Noções de Direito Administrativo. NOVA, 2015.

SILVA, C. H. J. Princípios Orientadores da Segurança Pública e Limitadores da Atividade Policial, à luz da Constituição Federal e das modernas tendências legislativas. Disponível em: http://www2.tjam.jus.br/esmam/index.php?option=com_docman\&task=doc_details\&gid=6\&t $\mathrm{mpl}=$ component\&Itemid=90. Acesso: 15 mar. 2021.

SILVA, F. C. S. da. Aspectos legais do emprego do exército na garantia da lei e da ordem. Disponível em http: //www.ambitojuridico.com.br/site/index.php?n_link=revista_artigos_leitura\&artigo_id=1179. Acesso: 15 mar. 2021.

SILVA, J. A. da. Direito Constitucional Positivo. 16. ed. São Paulo: Malheiros, 1999.

SILVA, J. A. da. Curso de Direito Constitucional Positivo. 23. ed. São Paulo: Malheiros, 2004.

ZERO HORA. Comandante do Exército diz que uso de militares em segurança é "perigoso". 2017. Disponível em:

http://zh.clicrbs.com.br/rs/noticias/policia/noticia/2017/06/comandante-do-exercito-diz-queuso-de-militares-em-seguranca-e-perigoso-9823097.html. Acesso: 15 mar. 2021. 


\title{
O PROCESSO DE INTERNACIONALIZAÇÃO DE EMPRESAS E OS PROBLEMAS LOGÍSTICOS NA EXPORTAÇÃO BRASILEIRA EM VIRTUDE DA PANDEMIA DE COVID-19
}

\author{
THE INTERNATIONALIZATION PROCESS OF COMPANIES AND \\ LOGISTIC PROBLEMS IN BRAZILIAN EXPORTS IN THE VIRTUE OF \\ THE COVID-19 PANDEMIC
}

FERREIRA, Aline ${ }^{1}$

\section{Resumo}

A internacionalização, de um modo geral, tornou-se relevante estratégia empresarial, pois com ela as empresas garantem acesso ao mercado internacional e ampliam as chances de sucesso, superando prováveis barreiras comerciais. A escolha desse tema deu-se, por buscar conhecimento sobre o impacto da pandemia de coronavírus no mercado de exportação brasileira, já que se trata de um tema pouco explorado, carente de conteúdo científico. $\mathrm{O}$ objetivo geral deste trabalho consiste em analisar estratégias de internacionalização utilizadas para enfrentar dificuldades logísticas existentes na exportação brasileira durante a pandemia da Covid-19. E os objetivos específicos consistem em: verificar se a internacionalização das empresas brasileiras segue algum tipo de modelo; levantar os problemas logísticos enfrentados pela logística internacional de transportes no Brasil; identificar estratégias pós-pandemia para a exportação brasileira. Como metodologia realizou-se um estudo bibliográfico em livros, revistas, jornais artigos e sites relacionados ao assunto como intuito de fazer o embasamento teórico.

Palavras-chave: Internacionalização. Logística. Exportação. Pandemia do Coronavírus.

\begin{abstract}
Internationalization, in general, has become a relevant business strategy, since with it companies guarantee access to the international market and expand the chances of success, overcoming probable trade barriers. This theme was chosen because it sought knowledge about the impact of the coronavirus pandemic on the Brazilian export market, since it is a little explored topic, lacking scientific content. The general objective of this work is to analyze internationalization strategies used to face logistical difficulties existing in Brazilian exports during the Covid-19 pandemic. And the specific objectives are: to check if the internationalization of Brazilian companies follows some type of model; to raise the logistical problems faced by international transport logistics in Brazil; identify post-pandemic strategies for Brazilian exports. As a methodology, a bibliographic study was carried out on books, magazines, newspapers, articles and websites related to the subject in order to make the theoretical basis.
\end{abstract}

Keywords: Internationalization. Logistics. Export. Coronavirus pandemic.

\footnotetext{
${ }^{1}$ Graduação em Comunicação Social, Jornalismo - FACE. Graduação em Comércio Exterior - Pitágoras Ampli. Pós-Graduada em Docência do Ensino Superior e Tutoria EAD - Instituto IBRA. Mestranda em Docência Universitária. FUNIBER. E-mail: a.ferreiraeduca@gmail.com 


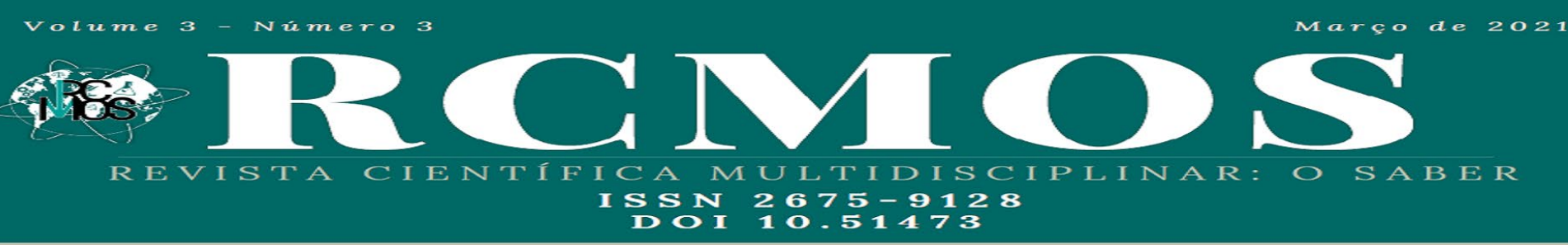

problemas logísticos enfrentados pela logística internacional de transportes no Brasil; identificar estratégias pós-pandemia para a exportação brasileira.

Para alcançar os objetivos traçados, respondendo a problematização levantada fez-se um estudo bibliográfico em livros, revistas, jornais artigos e sites relacionados ao assunto como intuito de fazer o embasamento teórico.

\section{Metodologia}

Para o desenvolvimento deste artigo utilizou-se como metodologia uma pesquisa bibliográfica em livros, revistas, jornais, artigos e sites relacionados ao assunto. Método, de acordo com Gil (2007, p. 26) "é o caminho para se chegar a um determinado fim e método científico são métodos intelectuais e técnicos, adotados para se atingir um conhecimento".

Pesquisar consiste em buscar respostas mediante o uso de procedimentos científicos. De acordo com Tartuce (2013, p. 30), trata-se do "conjunto de ações propostas para encontrar a solução de um problema, que tem como base procedimentos racionais e sistemáticos”. Assim, com base na autora, é possível dizer de forma simples que pesquisa se trata de buscar resposta para uma ou mais indagações realizadas acerca de determinado assunto.

Dessa forma, a pesquisa consiste em uma investigação que tem como base procedimentos científicos para encontrar respostas para determinado problema. Como bem afirmam Gerhardt e Silveira (2009), uma pesquisa somente pode ser iniciada se existir uma pergunta cuja resposta precisa ser desvendada, ou seja, uma dúvida para a qual se quer buscar respostas.

\section{Fundamentação Teórica}

\subsection{Teorias de Internacionalização}

A internacionalização compreende a atuação da empresa em outras nações, através de métodos e procedimentos desenvolvidos no âmbito internacional, como a comercialização de produtos e serviços em outros países, a transferência de capitais e o desenvolvimento de projetos com parceiros estrangeiros.

Desta forma, corroborando com os autores acima citados pode-se dizer que a internacionalização de empresas abrange todo o tipo de intervenção avançada nos mercados externos, envolvendo desde a exportação até o investimento direto no exterior. Vale ressaltar que o processo de internacionalização de empresas expõe as empresas a incertezas e riscos, 


\section{Votume 3 - Número 3

3.2 Comércio internacional e sua influência no desenvolvimento local

A internacionalização favorece o crescimento consistente com a estratégia ao abrir maiores mercados para uma estratégia de enfoque. Ao contrário da ampliação do mercado interno, a expansão global provavelmente alavancará e reforçará a identidade e a posição exclusiva da empresa. Pode-se compreender que a exportação encontra limites para o desenvolvimento pleno de uma região, e que, os benefícios podem ficar limitados a determinadas atividades econômicas (ROMEIRO, 2012). Desta forma, a decisão de usar o regime deve ser avaliada de maneira integrada por todos os setores envolvidos direta e indiretamente no abastecimento, na produção e na distribuição da empresa.

Araújo e Sartori (2004) citaram outras vantagens, como a dispensa de transporte em navio de bandeira brasileira e o exame de similaridade, condições exigíveis quando há isenção ou redução da alíquota do imposto de importação.

Existem vários modos de entrada no mercado que possibilitam o acesso a produtos, tecnologia, administração e recursos humanos no mercado estrangeiro. Estes são classificados em exportação, contratual e investimento, conforme o quadro 1:

Quadro 1. Classificação dos Modos de Entrada

\begin{tabular}{|c|c|c|}
\hline Por Exportação & Contratual & Por investimento \\
\hline Indireta & Licenciamento & Investimento Greenfield \\
\hline Cooperativa & Franchising & Aquisição \\
\hline Direta & Acordo técnico & Subsidiária Controle Integral \\
\hline & Contrato de serviços & Joint Venture / Sole Venture \\
\hline & Contrato de Administração & \\
\hline & Contrato de Produção & \\
\hline & Aliança Contratual & \\
\hline
\end{tabular}

Fonte: Adaptado de Root, 1987.

Rocha e Almeida (2006) definem entrada por exportação como aquela em que os produtos são fabricados fora do país de destino e transferidos para ele, tendo pouca chance de expandir para o exterior. Dentre os tipos de exportação cita-se: i) a exportação indireta onde o intermediário que se internacionalizou pode ser uma empresa exportadora, uma trading company ou um agente de exportação; ii) a exportação cooperativa em que a empresa exportadora tem controle de suas operações, compartilhando de recursos e riscos para que possa ingressar no mercado internacional; e iii) exportação direta permitindo que a empresa tenha mais controle sobre suas atividades internacionais através de escritórios próprios no exterior ou filiais. Quanto à exportação contratual, esta confere conhecimentos e competências para um país por meio de licenciamento, onde há troca de ativo, franchising em que cede a terceiros o 


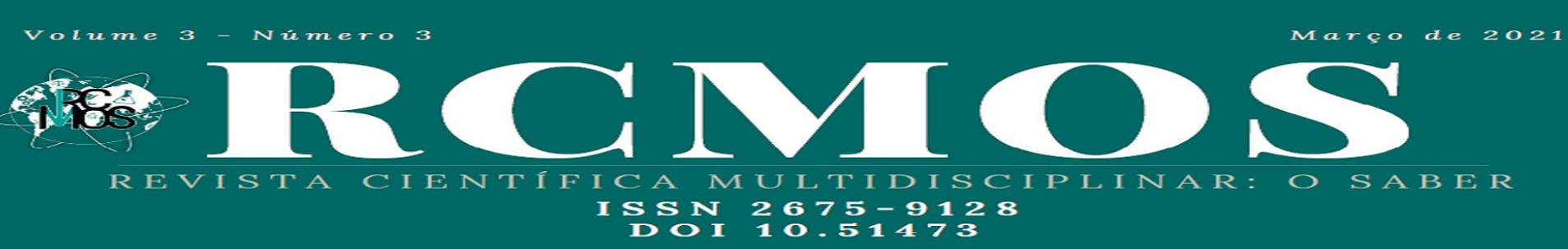

direito de distribuir seus produtos e serviços e contrato de produção na qual uma empresa atua como subcontratada da outra. (ROCHA; ALMEIDA, 2006).

O modo de entrada por meio de subsidiárias de controle integral é um dos mais utilizados pelas empresas brasileiras, que consiste basicamente na instalação de uma empresa subsidiária no país em que pretende se estabilizar. Um exemplo de empresas que utilizam desse modo de entrada são as instituições bancárias brasileiras. (FRANCO, 1998). O Join Venture consiste em um contrato de colaboração empresarial, o modo de entrada a partir deste ocorre por meio da celebração de um contrato entre duas ou mais empresas, pelo qual outra empresa surge. Como exemplo de Join Venture, utilizado para internacionalização, cita-se a Springs Global, que foi formada a partir da celebração de um contrato entre a empresa brasileira Cteminas e a empresa Americana Springs.

Amatucci (2009, p.150) destaca que "as empresas podem optar por comercializar seus produtos e serviços de forma padronizada ou adaptada. Essas decisões estão relacionadas à estratégia de marketing mix internacional”. Entende-se, portanto que a decisão de qual modo de entrada deve ser utilizada depende das condições competitivas da empresa, suas capacidades e competências essenciais. Desta forma, cada empresa pode adotar seu modus operandi para sua internacionalização, sendo no Brasil o mais utilizado a entrada por meio de Subsidiárias de Controle Integral.

\subsection{Logística de transporte no comércio exterior brasileiro}

O comércio exterior brasileiro exerce grande importância para a economia do país, atuando também no desenvolvimento social, já que é gerador de empregos, assim, buscar meios para melhorar seus resultados é fator fundamental. A logística de transporte é um dos fatores que mais impactam no sucesso de uma empresa. Betarelli Júnior (2012) destaca a importância do transporte na logística internacional, afirmando ser ele o impulsionador das atividades, podendo refletir na imagem da empresa, já que implica na agilidade e qualidade da entrega do produto.

A partir do exposto entende-se a importância da logística de transporte no comércio exterior brasileiro, podendo destacar que problemas nesse setor podem afetar todo o negócio das empresas exportadoras. Ressalta-se que muitas empresas contam com prestadores de serviços logísticos para o transporte de suas cargas, tendo em vista a falta de infraestrutura para tanto, acontece que esses profissionais têm esbarrado em barreiras logísticas no Brasil que tem 


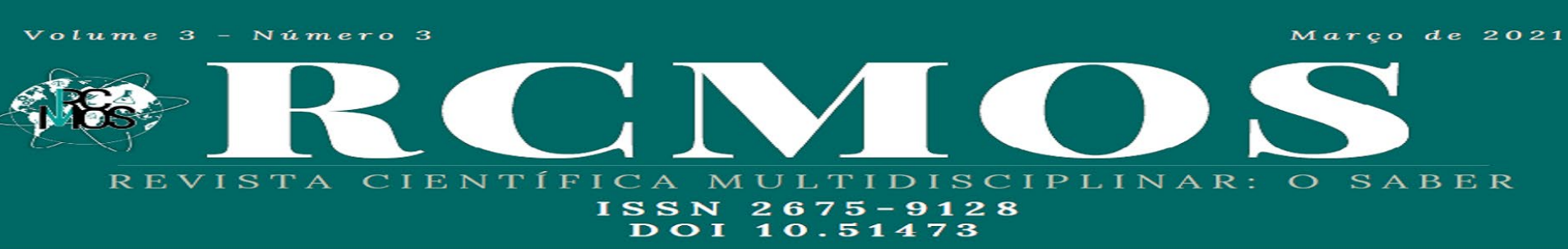

dificultado seu trabalho, gerando um efeito dominó com a imagem do prestador de serviço e da empresa exportadora.

Entende-se que a logística consiste em um dos principais instrumentos de efetivação da exportação, envolvendo desde a forma de armazenamento até a entrega ao consumidor final, nesse caso foca-se no processo de saída do produto do país de origem (empresa exportadora) até o país de destino (empresa importadora / consumidor final). De acordo Novaes (2011), o prestador de serviço logístico é aquele especializado em no gerenciamento da cadeia de suprimentos, desde a agregação de valor ao produto até a gestão de transporte, sendo este último o alvo deste estudo. As empresas exportadoras por vezes optam por contratá-los, terceirizando o transporte de seus produtos nas atividades de comércio exterior, tendo em vista os custos demandados para ter um departamento próprio para tanto. Assim, a terceirização dos serviços logísticos tem sido uma constante, devendo-se lembrar que são estes prestadores de serviço que ficarão como responsáveis pela pontualidade e qualidade dos produtos entregue, bem como que qualquer problema nesta etapa trará problemas para toda a cadeia de suprimentos.

Todavia, existem problemas externos aos prestadores de serviços que tem incidido na confiabilidade de suas atividades, como os problemas logísticos mencionados que envolvem burocracia, portos saturados, infraestrutura de acesso rodoviário, custo portuário, deficiência na armazenagem, demora na liberação dos produtos, custo com demurrage, autoridades públicas, janela de atracação de navios e acesso ferroviário. Problemas estes que dificultam o trabalho dos operadores logísticos, fazendo ocorrer um prejuízo em efeito dominó, derrubando tanto a imagem do prestado de serviço quanto da empresa exportadora, tendo em vista que o consumidor final pouco se importa com o que motivou a demora de sua entrega, mas sim se foi atendido dentro do combinado.

Diante do exposto, entende-se que os problemas logísticos presentes no Brasil que vão desde a burocracia demandada até a infraestrutura de portos, rodovias e ferrovias, sendo necessários investimentos do Governo nessa área, bem como a desburocratização do processo, considerando que se trata de uma atividade fundamental para o crescimento do comércio exterior brasileiro.

3.4 O impacto da pandemia da Covid-19 nas exportações brasileiras

Além de afetar a saúde global, impactou no comércio exterior e consequentemente nas exportações brasileiras, acarretando em problemas no setor logístico das empresas. Dentre as 


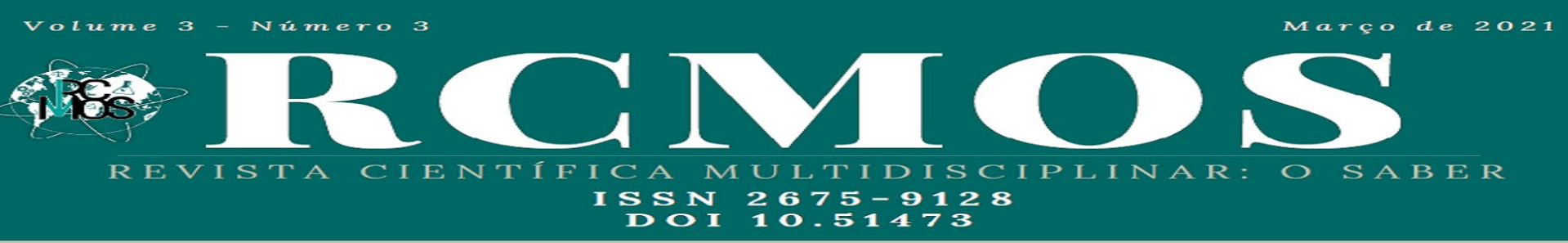

principais mudanças que aconteceram nas exportações brasileiras tem-se a adoção de protocolos de diferentes países, sendo preciso adaptar-se para atender todas as exigências do mercado global; apreensão com o desabastecimento em virtude do fechamento de fronteiras, fazendo com que a cadeia de suprimentos passasse a ser monitoramento, e outros (INTERMODAL DIGITAL, 2020).

Conforme dados obtidos pela Confederação Nacional da Indústria - CNI, cerca de 57\% das empresas brasileiras tiveram suas exportações reduzidas em virtude da pandemia de covid19 (CNI, 2020).

Gráfico 1 - Efeito da pandemia sobre a atividade de exportação até o momento

Efeito da pandemia sobre a atividade de exportação até o momento Percentual (\%) do total de empresas exportadoras

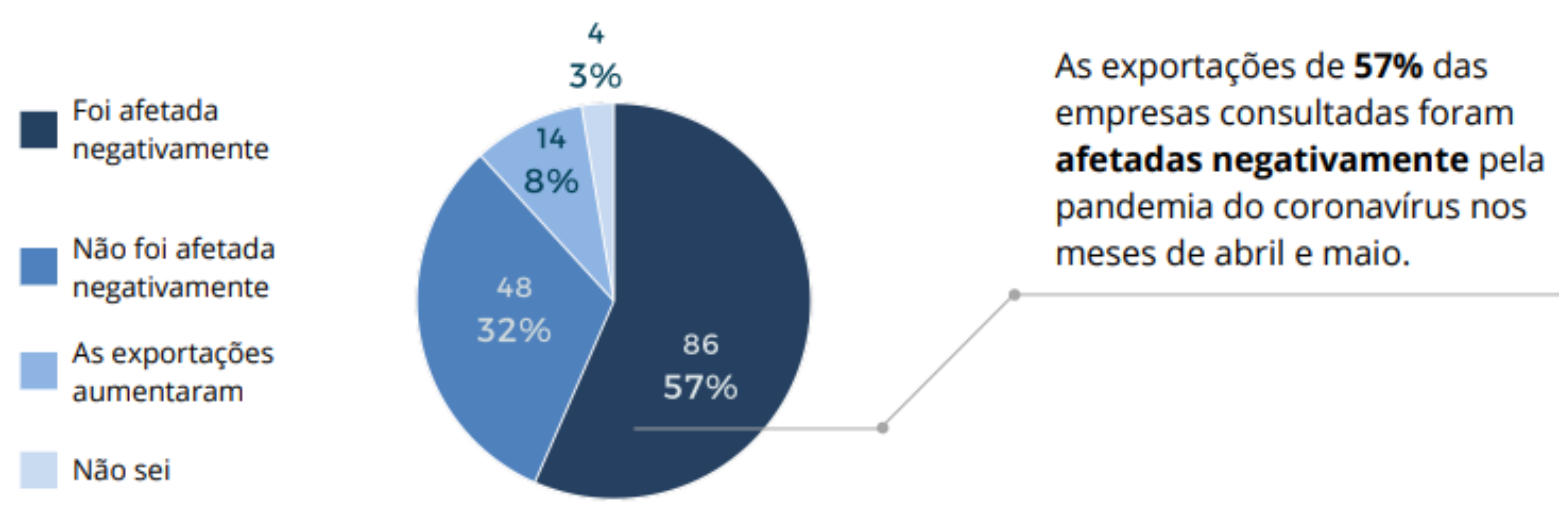

Fonte: CNI, 2020.

Dentre as preocupações das empresas que atuam nesse mercado, cita-se redução das exportações, variação cambial, inadimplência e aumento dos custos logísticos. No que se refere aos impactos na logística de exportação, tem-se a dificuldade em enviar e receber documentos em alguns destinos em virtude do lockdown e suspensão nas rotas internacionais.

\section{Considerações finais}

No decorrer deste trabalho pode-se entender acerca do processo de internacionalização das empresas, iniciando-se pelo conhecimento das teorias que tentam explicar a internacionalização das empresas. Foi visto que a logística empresarial é capaz de promover o desenvolvimento estratégico de uma empresa, haja vista que a mesma possibilita uma integração entre todos os setores da empresa, facilitando a observação de aspectos que precisam ser melhorados. Ao adotar a logística estratégica a empresa passa a se apoiar na mesma para 


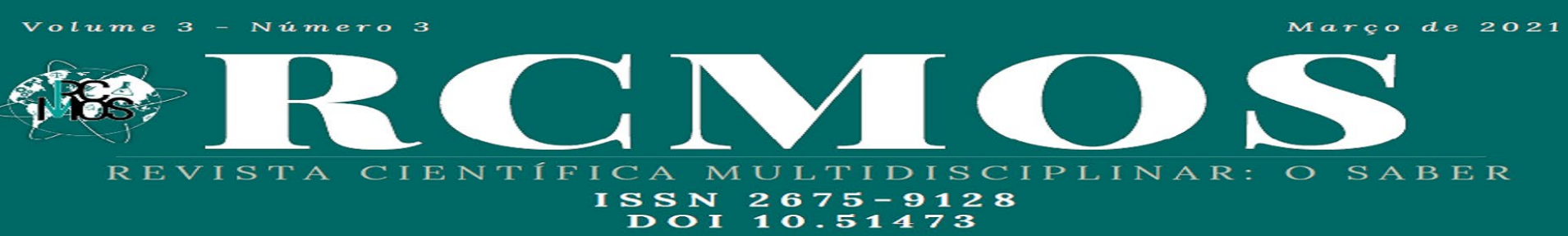

FRANCO, G. A inserção externa e o desenvolvimento. Revista de Economia Política, v. 18, n. 3 v.71, p. 121-147, jul. /set. 1998.

GERHARDT, T. E.; SILVEIRA, D. T. (org.). Métodos de Pesquisa. Porto Alegre: Editora da UFRGS, 2009.

GIL, A. C. Como elaborar projetos de pesquisa. 4. ed. São Paulo: Atlas, 2002.

HEMAIS, C. A. (Org.). Os Desafios dos Mercados Externos. Teoria e Prática na Internacionalização da Firma. Coleção Estudos COPPEAD, v. 1, Rio de Janeiro, Mauad, 2004.

INTERMODAL DIGITAL. Os reflexos da pandemia nas exportações brasileiras: o que mudou? 2021. Disponível em: https://digital.intermodal.com.br/modais/os-reflexos-dapandemia-nas-exportaes-brasileiras-o-que-mudou. Acesso em: 25 mar. 2021.

MADEIRA. T. P. G. Internacionalização de micro e pequenas empresas (MPE'S) aplicando a técnica de Benchmarking: um estudo de caso na empresa Aroma da Terra. Trabalho de Conclusão de Curso. Relações Internacionais da Universidade do Sul de Santa Catarina. Florianópolis, 2015.

MENEZES, U. G. de. Teorias sobre internacionalização. Administradores.com, 2010. Disponível em: http://www.administradores.com.br/artigos/marketing/teorias-sobreinternacionalizacao/43608/. Acesso em: 21 mar. 2021.

NOVAES, A. G. Logística e Gerenciamento da Cadeia de Distribuição: estratégia, operação e avaliação. Rio de Janeiro, Elsevier, 2011.

ROCHA, A.; ALMEIDA, V. Estratégias de entrada e de operação em mercados internacionais. In: TANURE, Betânia; DUARTE, Roberto G. (Org.). Gestão internacional. São Paulo: Saraiva, 2006.

ROMEIRO, A. R. Desenvolvimento sustentável: uma perspectiva econômicoecológica. Estud. av., São Paulo, v. 26, n. 74, p. 65-92, 2012. Disponível em https://doi.org/10.1590/S0103-40142012000100006. Acesso em: 21 mar.2021.

SCHULTZ, G. Introdução à gestão de organizações. SEAD/UFRGS. - Porto Alegre: Editora da UFRGS, 2016.

SILVA, I. M. da. A decisão de internacionalização em uma pequena empresa: o caso D’accord. In: XXXI XXX Encontro da Associação Nacional de Pós-Graduação e Pesquisa em Administração - ENANPAD. Anais. Rio de Janeiro: Anpad, 2011.

TARTUCE, F. A função social da posse e da propriedade e o direito civil constitucional. 2013. Disponível em: http://www.mundojuridico.adv.br/sis_artigos/artigos.asp?codigo=159. Acesso em: 21 mar. 2021. 


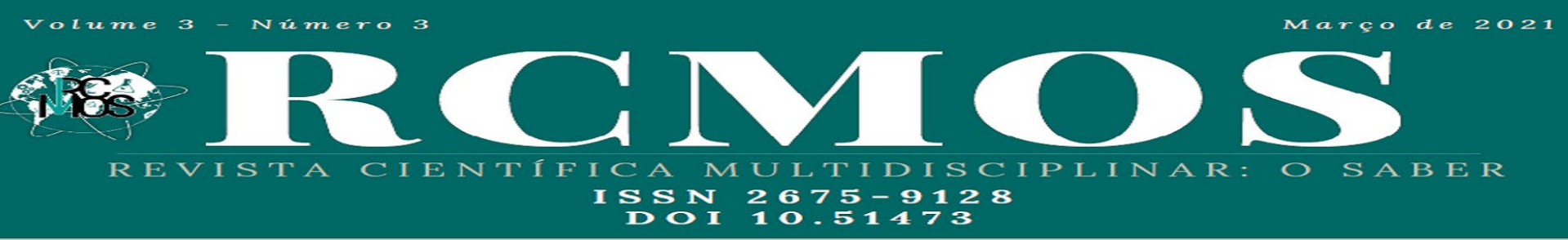

A EXPERIÊNCIA RELIGIOSA DE ROBERTH McALISTER

THE RELIGIOUS EXPERIENCE OF ROBERTH MCALISTER

GOMES, Maurício Antônio de Araújo ${ }^{1}$

\title{
Resumo
}

Neste artigo será apresentada a experiência religiosa de Robert McAlister, com uma abordagem de sua biografia com os principais acontecimentos de sua vida. Posteriormente, um panorama sobre a Igreja Pentecostal de Nova Vida, desde a fundação até o presente momento, os livros escritos por ele e a declaração de fé da IPNV. Finalmente, um relato da sua experiência religiosa com base em Eliade ${ }^{2}$ e Otto ${ }^{3}$.

Palavras-chave: Igreja Nova Vida. Robert McAlister. Pentecostalismo.

\begin{abstract}
In this article will be presented the religious experience of Robert McAlister, discussing a biography of the main events of his life. In addition, a panorama about the Pentecostal Church of New Life, from the foundation to the present moment, the books written by him and the IPNV declaration of faith. Finally, an account of his religious experience based on Eliade and Otto.
\end{abstract}

Keywords: New Life Church. Robert McAlister. Pentecostalism.

\section{Introdução}

O missionário Robert McAlister, por mais de trinta anos, exerceu grande influência no protestantismo no Brasil, sendo o percursor de várias Igrejas Neopentecostais, como Universal

1 Graduação em Teologia pela UMESP (Universidade Metodista de São Paulo), licenciado em História pela UNIJALES (Centro Universitário de Jales), pós-graduado em psicopedagogia e ciências da religião, mestre em Ciência da Religião pela Universidade Federal de Juiz de Fora e graduando em Direito pela Doctum. E-mail: Mauricioantonio37@yahoo.com.br.

2 O pensador, mestre, historiador especialista em questões religiosas, mitólogo e escritor romeno Mircea Eliade nasceu em Bucareste, no dia 28 de fevereiro de 1907, e morreu em Chicago, no ano de 1986. Em 1970 ele conquistou a cidadania norte-americana; o intelectual falava e discursava fluentemente em pelo menos oito idiomas, embora grande parte de sua obra acadêmica tenha sido elaborada na sua própria língua. Ele se converteu em um dos mais importantes historiadores e filósofos das religiões do mundo moderno, integrando posteriormente o Círculo Eranos, devotado a pesquisas espirituais (https://www.infoescola.com/filosofia/o-pensamento-demircea-eliade/).

3 Rudolf Otto (Peine, 25 de setembro de 1869, Marburg, 6 de março de 1937) foi um eminente teólogo luterano alemão, filósofo e erudito em religiões comparadas. Autor de O Sagrado (ou A Ideia do Sagrado), publicado pela primeira vez em 1917 como Das Heilige (considerado um dos mais importantes tratados teológicos em língua alemã do século XX) e que é mais conhecido pelo seu conceito do numinoso [nota 1], o qual exprime uma profunda experiência emocional que ele argumentou estar no coração das religiões do mundo e que é fundamental no entendimento religioso e filosófico da atualidade (https://pt.wikipedia.org/wiki/Rudolf_Otto). 


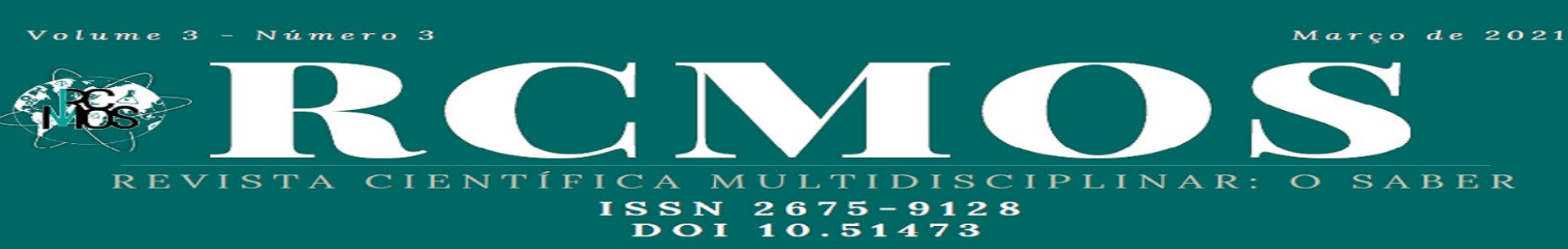

do Poder de Deus e Internacional da Graça. Há pouca publicação sobre ele e sua atuação missionária no Brasil, após os anos 1960.

Inicialmente, será apresentada sua biografia incluindo os relatos dos fatos que o fizeram vir ao Brasil para constituir a Igreja Pentecostal de Nova Vida, após ter visitado o País em sua lua de mel e, segundo ele, ter ouvido um chamado para realizar um trabalho de evangelização. Também será narrada a história da fundação da Igreja, mostrando todos os fatos que ocorreram anteriormente à sua fundação até os dias atuais. No final, será abordada sua experiência religiosa baseada nos relatos de Eliade Mircea e Rudolf Otto.

\section{Fundamentação teórica}

\subsection{Biografia de Robert McAlister}

Walter Robert McAlister nasceu em 13 de agosto de 1931, na cidade de London (Canadá), em uma família evangélica, sendo filho e neto de pastores pentecostais. Ele teve dois irmãos, Elizabeth e Jack, e todos foram educados dentro dos princípios evangélicos (MCALISTER, 2012, p. 12).

. Seu pai, Walther Edward McAlister, era um homem de características humildes que atuava como missionário itinerante em uma denominação chamada Igreja da Pedra, em Toronto (Canadá), que tinha como ideal a evangelização e, consequentemente, a criação de novas igrejas na região que abrangia de Toronto até Vancouver. Sua mãe era dona de casa e se ocupava da criação dos filhos.

Na juventude, Robert passou por uma fase de indiferença em relação à religião de seus pais, mas em 18 de setembro de 1948, aos 17 anos, teve sua experiência religiosa, ou conversão como caracteriza o estudo evangélico. Nesta idade, ele já trabalhava como inspetor de seguros de carros.

Em consequência à sua experiência de conversão, Robert deixou o emprego e decidiu ser um missionário, seguindo os passos do avô e do pai. Ele relata que teve um chamado divino para a missão e estudou por um período de três anos em Peterborough, na Escola Bíblica Eastern Pentecostal Bible College.

Ao terminar esse período de formação, ele teve o desejo de ir para o campo missionário para evangelizar e fundar Igrejas, o que aconteceu com a sua viagem para as Filipinas, onde ingressou em uma missão evangélica com a função de solista, pois cantava no coral da igreja. Ao desenvolver seu trabalho missionário, Robert se deparou com uma dificuldade quando 


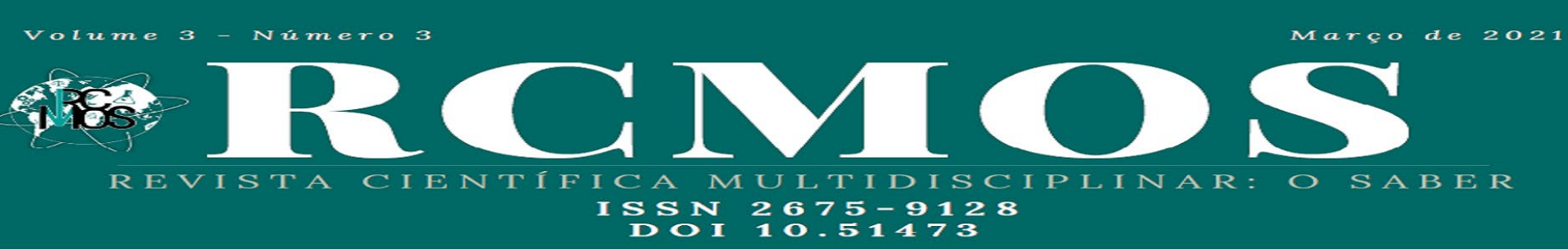

começou a orar pelos enfermos, algo que não era aceito pela missão que o advertiu por essa prática, já que ela só poderia ser realizada na época dos discípulos. Todavia, ele fora criado no ambiente pentecostal, onde era comum o uso dos dons espirituais e também vivenciou a cura de uma enfermidade na garganta. Assim, ele se desligou da missão.

Com o passar do tempo, ele conheceu o pastor pentecostal Lester Summral, que desenvolvia um trabalho missionário nas Filipinas e pediu para ingressar na missão para desenvolver seu ministério pentecostal (MCALISTER, 2012, p. 15).

Ali, ele trabalhou por algum tempo como missionário e chamou Hugh McAlister, seu tio, para ajudá-lo em campanhas evangelísticas com a ministração de cura divina. Eles realizaram um mistério com ênfase nos dons do Espírito Santo.

Algum tempo depois, eles saíram das Filipinas e, aproveitando uma oportunidade na viagem, passaram pela Índia, onde fizeram uma cruzada evangélica. Em seguida, retornaram aos Estados Unidos.

Em uma viagem missionária, Robert se dirigiu para Carolina do Norte, onde conheceu Glória Garr, que era de Charlote e filha do missionário pentecostal Dr. Alfred Goodrich Garr. Depois de três dias em que se conheceram, ele a pediu em casamento que ocorreu no dia 10 de junho de 1955.

Nesta ocasião, Robert foi convidado para ir ao Brasil para realizar uma campanha evangelística, na cidade de Santos (São Paulo). Ele e sua esposa passaram a lua de mel nesta cidade e depois partiram em um navio rumo ao porto de Santos. Ressalta-se que esse foi o primeiro contato de Robert com o País.

Após a estadia em terras brasileiras, eles retornaram às suas viagens missionárias e foram para Hong Kong, onde surgiu uma denominação - "Nova Vida". Depois, foram para França, Alemanha e Índia.

Neste último País, tendo o mesmo objetivo de evangelizar, Robert e sua esposa foram impedidos de desembarcar, pois ele, como um canadense, poderia visitar a Índia, mas sua esposa americana não. Todavia, esse objetivo se realizou em parte, pois Robert deu o dinheiro que tinha guardado para o trabalho missionário naquele local para seu amigo Mark Buntaim, que ali trabalhou por vários anos.

Após a tentativa de ir para Índia não ter dado certo, eles voltaram para Charlotte. Depois, foram convidados para fazer outra campanha no Brasil, no Estádio do Maracanãzinho, no 


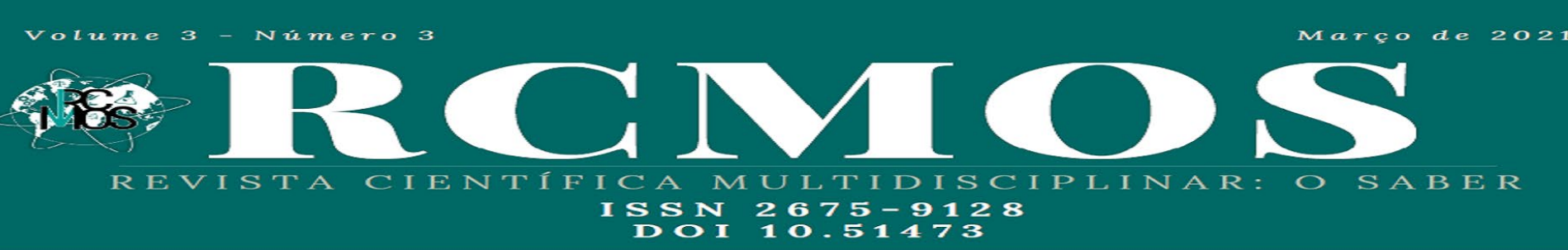

Estado do Rio de Janeiro. Sua intenção, ao terminar essa campanha, era continuar suas viagens como missionário itinerante levando a palavra de Deus.

Ao chegar ao Rio, ele sentiu que Deus lhe mostrava que o Brasil seria o lugar onde pregaria sua mensagem evangelística por um bom tempo, porém ao término da campanha voltou para o Canadá, uma vez que sua filha estava enferma. Robert McAlister foi superintendente geral das Assembleias Pentecostais do Canadá.

No ano de 1959, Robert veio para o Brasil juntamente com toda sua família, ou seja, esposa e os dois filhos (Walter com dois anos e Heather com seis meses). A cidade de São Paulo foi seu primeiro destino, mas no tempo em que ali ficou não conseguiu desenvolver seu ministério evangelístico, por isso mudou para a cidade do Rio de Janeiro e fundou a Cruzada de Nova Vida.

Em 1960, ele começou um programa chamado "Voz da Nova Vida" que foi transmitido pela Rádio Copacabana e depois pelas Rádios Mayrink Veiga e Guanabara, alcançando expressiva audiência.

No ano de 1961, Robert conseguiu um local apropriado no nono andar da Associação Brasileira de Imprensa, onde iniciou suas pregações. Também implantou um escritório pastoral na Avenida Rio Branco para atendimentos às pessoas que precisassem de oração e aconselhamentos.

Em 1967, ele conseguiu comprar a Rádio Relógio que foi a pioneira das rádios evangélicas no Rio de Janeiro, onde iniciou a transmissão de um programa intitulado "Café Espiritual da Manhã".

O primeiro templo da Igreja Pentecostal de Nova Vida foi inaugurado no ano de1964, na zona norte da cidade do Rio de Janeiro. Em 1972, veio o segundo templo no bairro do Botafogo, onde se encontrava também a sede administrativa da Igreja e alguns apartamentos para os pastores.

Em 1973, Robert tomou a decisão de se afastar da direção da Igreja Pentecostal Nova Vida por tempo indeterminado e foi para os Estados Unidos, dedicando-se a um período sabático durante três anos.

. O Bispo Tito Oscar assumiu então a liderança da Igreja. Após esse período, Robert retornou ao Brasil e reassumiu a Igreja Pentecostal de Nova Vida. Em 1978, estreou o programa Coisas da Vida na extinta TV Tupi e também escreveu mais de 35 livros (MCALISTER, 2012, p. 12). Robert já apresentava alguns problemas cardíacos e aos trinta e nove anos teve o primeiro 


\section{Votume 3 - Número 3

Igreja Pentecostal de Nova Vida. Como o governo da Igreja estava centralizado em um bispo e uma sede administrativa e com a demanda de seu crescimento, houve uma sobrecarga administrativa. A primeira medida foi a de retirar do nome da igreja o termo Pentecostal para que não houvesse confusão com o neopentecostalismo. Ela passou a ser chamada de Igreja de Nova Vida.

Outra decisão tomada por Robert foi a cisão patrimonial da Igreja, concedendo autonomia administrativa e financeira para todas. Essa medida deu total liberdade aos pastores para caminharem, sendo criado um Cadastro Nacional de Pessoa Jurídica.

Sob a liderança de Robert, a Igreja Nova Vida se expandiu por vários estados brasileiros, chegando a ter uma média de setenta templos. Atualmente, ela continua firme em seu propósito de evangelização.

\subsection{Experiência religiosa}

Ao analisar a experiência religiosa de Robert percebe-se que ele viveu os primeiros anos de sua vida no contexto religioso de seus pais, todavia na adolescência teve sua experiência com o sagrado. Segundo Eliade, "o homem toma conhecimento do sagrado porque este se manifesta, se mostra algo absolutamente diferente do profano" (ELIADE, 1992, p. 13). Esta experiência proporcionou uma ampla visão para Robert que definiu por completo a sua vida, ou seja, um valor existencial, uma criação de mundo (ELIADE, 1992).

Esta visão foi fundamentada em sua experiência com o cristianismo evangélico, em uma visão do Deus que se revela. Na concepção de Barth, a revelação é a manifestação da soberania de Deus ${ }^{4}$ para com o homem e o mistério. Para "Geheimnis [...] é a última instância de juízo sobre o ser humano" (BARTH,1996, p. 184). Cabe ao homem aceitá-la, visto que essa é a única forma de alcançar a salvação. Diante desta explicitação, a revelação está ancorada na figura de Jesus Cristo. Nas palavras de Mondin,

Com o termo "cristã", Barth quer dizer que não se pode pensar teologicamente "senão tendo diante dos olhos a figura viva de Cristo. Uma dogmática cristã deve ser cristologia em sua estrutura fundamental como em cada uma de suas partes, se é verdade que o seu único critério é a Palavra de Deus revelada e atestada pela Sagrada Escritura e pregada pela Igreja e se é verdade que essa Palavra de Deus revelada se

4Barth nunca se cansou de proclamar a soberania de Deus, tanto no ser, como no agir. No ser, a distância entre Deus e as criaturas é tão infinita que ele pode tudo e a criatura nada. No agir, Deus faz tudo, razão pela qual não há nem cooperação nem liberdade de ação na criatura. "Deus é Deus, sendo totalmente diverso de qualquer realidade humana, inclusive da cultura e da religião do homem". Em 1922, em uma carta a um amigo, ele diz: "Nunca deixes de afirmar: 'Deus é Deus'. Não te contentes em pregá-lo. Aprende a afirmar que 'Deus é Deus' com precisão teológica, ou seja, com toda a exultação que a acompanha "Jesus é o Cristo" (MONDIN, 2003, p. 66). 


\section{Volume 3 - Número 3

identifica com Jesus Cristo". "A cristologia deve ocupar todo o espaço na teologia. [...] vale dizer, em cada ramo da dogmática e da eclesiologia [...]. A dogmática deve ser fundamentalmente uma cristologia e nada mais". Nessa preocupação de colocar Cristo no centro de toda a reflexão teológica está a nota mais inovadora e característica da obra de Karl Barth. Cristo constituiu o ponto de vista no qual Barth se coloca para entender todo o resto da Revelação (MONDIN, 2003, p. 46).

A sua manifestação está associada à liberdade de Deus em concedê-la ao homem que a confessa por intermédio da fé e com base em Jesus Cristo. O Deus desconhecido se torna conhecido através da revelação que toca e envolve a pessoa humana. Para Barth a palavra de Deus é o meio que Ele falou, fala e falará aos seres humanos, e a mesma agirá neles e a favor deles.

[...] em sua palavra, Deus revela o seu agir no horizonte de sua aliança com o ser humano; e na história da constituição, manutenção, realização e conclusão dessa aliança ele se revela a si mesmo. Revela a sua santidade, mas também a sua misericórdia de pai, de irmão, de amigos. Revela também o seu poder e a sua majestade como senhor e juiz do ser humano; revela, portanto, a si mesmo como o primeiro parceiro dessa aliança, a si mesmo como Deus do ser humano [...] revela o ser humano como seu filho e servo, como amado por ele e, portanto, como segundo parceiro da aliança; em síntese: revela o ser humano como ser humano de Deus (BARTH, 2007, p. 19).

Barth está mencionando a dupla revelação que é o conteúdo do evangelho, na qual a aliança divina proporciona um relacionamento entre Deus e o ser humano. Diante do entendimento de Barth sobre religião, com a revelação de Deus na sua obra a Carta aos Romanos, ele apresenta alguns pontos sobre a religião como projeção humana.

Esta visão do cristianismo (evangélico), como superior ao status de religião que aparece em Barth, é também a vertente de Robert, porém com um viés também pentecostal, mas a supremacia de Cristo é a sua revelação ao homem.

Em suma, para Robert McAlister a sua religião se torna o espaço sagrado que tem um valor existencial, há uma fundação de um mundo, ou seja, um ponto fixo, central (ELIADE, 1999, p. 26). Essa concepção o levou a vivenciar e divulgar essa experiência religiosa. Nas palavras de Otto é o aspecto energético como "vivacidade, paixão, natureza emotiva, vontade, força, comoção, excitação, atividade, gama" (OTTO, 1981, p. 27).

\section{Considerações finais}

Este artigo teve como principal objetivo apresentar a experiência religiosa do Pastor Robert McAlister, através de sua biografia que inclui os acontecimentos principais da sua vida, desde o nascimento até a morte. Também descreveu o panorama da Igreja Pentecostal de Nova 


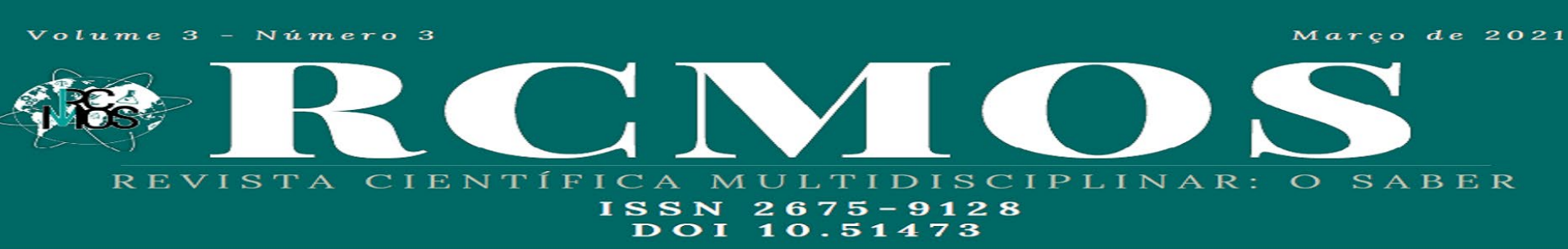

Vida fundada por ele, que muito influenciou nas suas escolhas como Ministro, escritor de diversos livros e declarante de uma inabalável fé em Deus.

Após um chamado, ele se converteu, estudou e tornou-se missionário seguindo o exemplo do pai e do avô. Ele enfrentou alguns empecilhos como, por exemplo, não ter sido autorizado a orar pelas pessoas enfermas, pois esta tarefa cabia apenas aos discípulos. Mais tarde, ele se desligou dessa missão

Robert cumpriu seu ministério como pastor em alguns países e nunca desistiu de cumprir seu propósito, como por exemplo no Brasil, onde fundou uma cruzada evangelística e criou programas de rádio para desenvolver seu ministério de evangelização. Ele também conseguiu um local apropriado para iniciar suas pregações, implantou um escritório pastoral para atendimentos às pessoas que precisassem de oração e aconselhamentos, comprou uma emissora de rádio para transmitir o evangelho e criou templos. Durante a sua vida, Robert vivenciou e divulgou a sua experiência religiosa fundamentada na verdadeira Palavra de Deus, até a sua morte.

\section{Referências}

ALTMANN, W. (Org). Carta aos Romanos. Tradução de Lindolfo K. Anders. São Paulo: Novo Século. 2007.

ALTMANN, W. (Org). Karl Barth - Dádiva e Louvor; artigos selecionados. Trad. Walter O. Schlupp, Luís Marcos Sander e Walter Altmann. São Leopoldo, Sinodal, 1996.

BÍBLIA. Português. Bíblia Sagrada contendo o Antigo e o Novo Testamento, Tradução de João Ferreira de Almeida. 2ed. Barueri: SBB. 1995.

CAMPOS, L. S. Templo, teatro e mercado. Petrópolis: Vozes; São Paulo: Simpósio; São Bernardo do Campo: UMESP, 1997

CONSELHO DE MINISTROS DAS IGREJAS DE NOVA VIDA DO BRASIL.

Disponível em: http://www.conselhonovavida.com.br. Acesso em: 25 set. 2018.

FRESTON, P. Breve história do Pentecostalismo brasileiro. In: ANTONIAZZI, A. Nem anjos nem demônios. Petrópolis, RJ. Vozes, 1994.

HORDERN, W. E. Teologia contemporânea. São Paulo: Hagnos. 2004.

IGREJA CRISTÃ NOVA VIDA. Disponível em: http://www.icnv.br Acesso em: 18 set. 2018.

MARIANO, R. Neopentecostais: sociologia do novo pentecostalismo no Brasil. São Paulo: Loyola, 1999. 


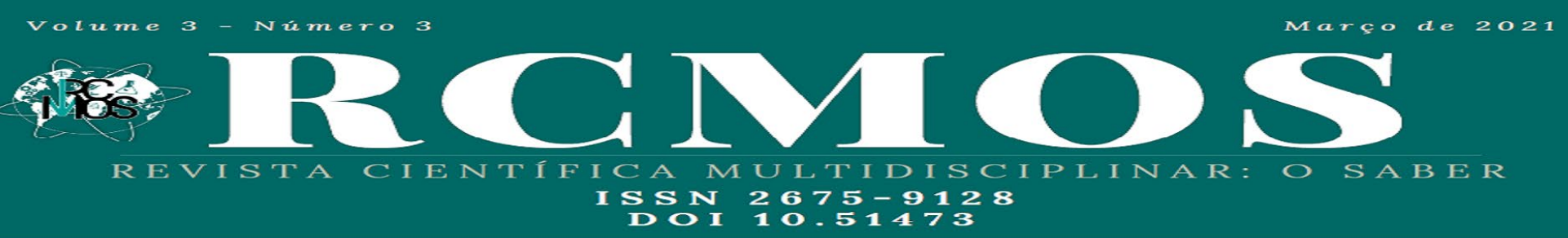

MCALISTER, W. Neopentecostalismo, a História Não Contada. Ed. Anno Domini, 2012 MIRCEA, E. O sagrado e o profano. São Paulo: Martins Fontes, 1992.

MONDIN, B. Grandes teólogos do século vinte. São Paulo: Editora Teológica, 2003.

NOSSA HISTÓRIA. Biografia do Bb. Robert McAlister. Disponível em:

https://www.conselhonovavida.com.br/nossa-historia/. Acesso em: 01 out. 2018.

OTTO, R. O sagrado. São Bernardo do Campo, Imprensa Metodista/ Instituto Ecumênico de Pós-Graduação em Ciências da Religião, 1985. 


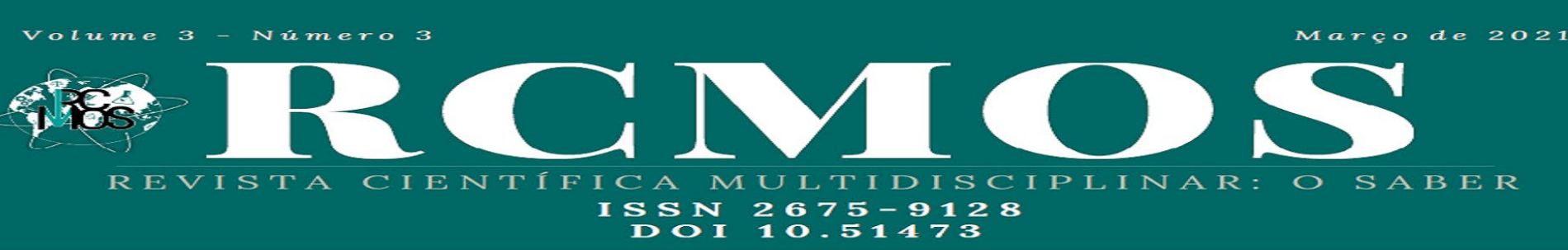

\section{Fundamentação teórica}

O cérebro é um órgão muito suscetível aos distúrbios que comprometem o suprimento sanguíneo, um exemplo é a isquemia, que pode provocar alterações nos sinais neurológicos ou até mesmo dano neural irreversível. O AVC pode acontecer quando o fluxo sanguíneo é interrompido devido à insuficiência de $\mathrm{O} 2$ ao cérebro. As causas principais deste tipo de AVC são, dentre outras, a hipertensão arterial, angiopatia amiloide e também por ruptura de um aneurisma cerebral. Os sintomas e sinais principais de um AVC são: cefaleia, disartria, alterações da consciência, afasia, visão turva, diplopia, vertigem, perturbações de equilíbrio, hemi ou monoparesia e também défices sensoriais (EKMAN, 2008).

Fisiologicamente o desencadeamento da espasticidade está diretamente ligado ao desequilíbrio que acontece entre as influências inibitórias e facilitadoras das vias descendentes responsáveis por regular o tônus muscular, favorecendo a desativação dos músculos flexores e resultando na liberação dos músculos extensores das articulações. Dependendo da região do cérebro que foi lesionada o AVC pode levar a incapacidades e disfunções motoras e sensoriais. Após o AVC acontece uma redução do tónus muscular ou, a hipotonia, a que se segue uma elevação progressiva do mesmo que se designa por hipertonia. Esta pode ter caraterísticas de rigidez ou espasticidade (DINIZ, 2003).

A espasticidade é a mais frequente, e é resultado de uma lesão do neurónio motor superior, especificamente, das vias corticoespinhais (tratos piramidais), denominada síndrome do neurónio motor superior. Resulta na perda do controle inibitório sobre os neurónios motores inferiores. Do ponto de vista funcional, a espasticidade pode ser definida como um distúrbio motor, onde sua característica principal é a elevação do reflexo de estiramento quando se imprime um estiramento passivo sob a dependência da velocidade e resistência ao mesmo. É, portanto, definida pelo grau de excitabilidade do fuso muscular que depende especificamente da velocidade com que os movimentos são realizados (MUSSE, 2002).

A fisioterapia é extremamente importante nas disfunções neurológicas, pelo fato de possuir inúmeros recursos que auxiliam a "melhorar" ou recuperar as capacidades motoras e funcionais dos doentes acometidos por esse tipo de disfunção. Evidências apontam a efetividade da fisioterapia após o AVC, e que quanto maior for a intensidade do tratamento, os resultados serão melhores. O estrago que um AVC causa no cérebro pode acarretar perda de sua função, mas por meio de um fenômeno denominado "neuroplasticidade", há a possibilidade de reajuste 


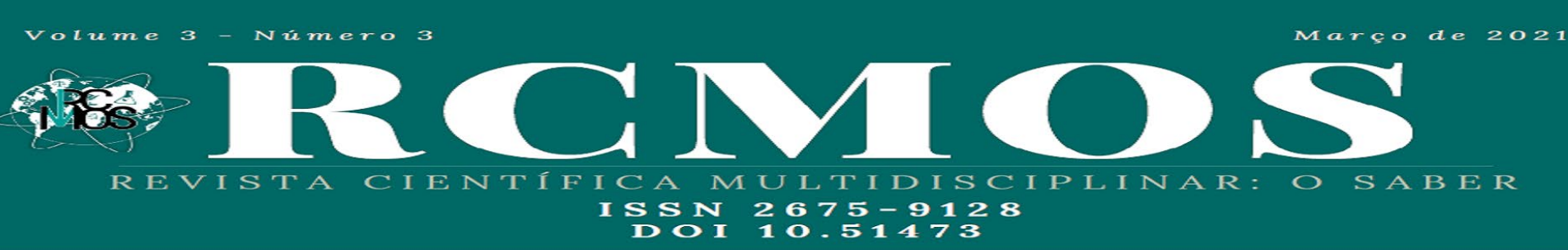

proprioceptiva que podem modular neuroplasticidade nas áreas motoras e soma tossensoriais (GAMBA, 2011).

A TRIM usa métodos do "não-uso aprendido", ou seja, o membro não atingido fica restrito da aplicação havendo somente o treinamento a utilização do membro comprometido, sendo assim irá acontecer o uso forçado do membro comprometido com o objetivo de provocar ganhos motores. Os princípios desta técnica consistem na restrição da extremidade superior que não está acometida pela lesão por $90 \%$ do dia, diretamente vinculado ao treino diário da extremidade que está comprometida por cerca de 6 horas todos os dias durante duas semanas, o que equivale a 10 dias úteis (PEREIRA, 2010).

Através do direcionamento novo da atenção estabelecido pela aplicação da TRIM, as capacidades que já existem, são aprimoradas e outras novas capacidades são aprendidas, acarretando melhora funcional do membro superior parético e mudanças neuronais no córtex cerebral que podem ser evidenciadas por meio da ressonância nuclear magnética. As influências e benefícios adquiridos por meio da neuroplasticidade referente a ganhos gerados pela TRIM, acontecem em decorrência dos seus três princípios básicos e fundamentalmente no treinamento motor do membro comprometido. Os princípios são basicamente a restituição, substituição e compensação (MARQUES, 2016).

Quanto mais cedo a reabilitação é iniciada, mais rapidamente e facilmente os benefícios da neuroplasticidade serão adquiridos, sendo uma das hipóteses a restrição da glicose reativa que representa um evento negativo no processo de recuperação da independência e funcionalidade motora. No que diz respeito as dificuldades encontradas em relação a aplicação desta terapia, referem-se à intensidade do tratamento, segurança e aderência do paciente. $\mathrm{Na}$ prática clínica é fundamental ressaltar o elevado custo do tratamento já que é essencial que o paciente permaneça no ambulatório diariamente por várias horas (GAMBA, 2011).

TRIM tem o objetivo central de influenciar o paciente a utilizar o membro parético por várias horas no dia, em dias consecutivos. Assim, é essencial a restrição da extremidade não afetada, sendo indicado para tal a utilização de tipoia ou luva, algo que possa impedir os movimentos. É importante uma avaliação pré e pós aplicação do método, desta forma mapeamento cortical antes e após a aplicação da TRIM em pacientes pós AVC deve ser realizado, geralmente é por meio de estimulação magnética transcrâniana, e também através de ressonância magnética funcional (PEREIRA, 2010). 


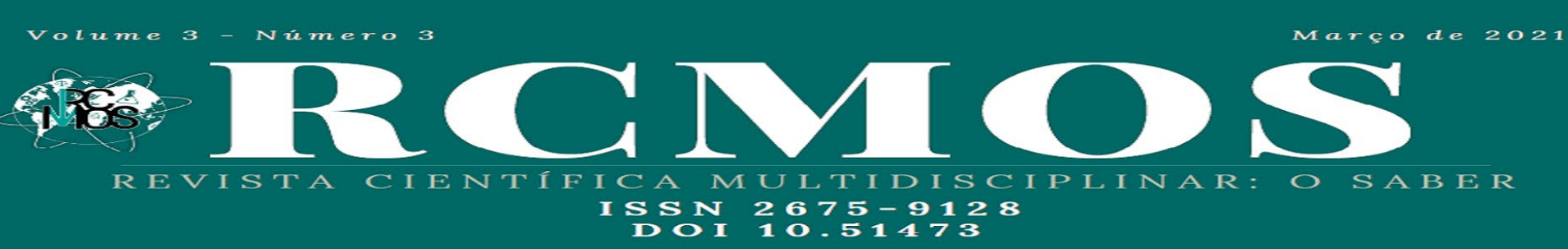

\section{Conclusão}

Contudo, diante da elevada incidência de AVC e dos danos causados, os estudos consultados trazem importantes contribuições no que se refere a melhoria e aprimoramento da reabilitação de pacientes espástico. Esta patologia é um problema de saúde mundial e o grande índice de pessoas com comprometimentos sensório-motor tem sido motivo para a busca de soluções direcionadas à recuperação.

A neuroplasticidade é extremamente importante para a reabilitação de paciente acometidos por AVC, e um dos métodos usados para estimulá-la é a TRIM, que demonstrou eficácia com resultados positivos no que diz respeito aos ganhos motores na realização das atividades de vida diárias, e qualidade de vida, refletindo de forma positiva no desenvolvimento e independência do paciente lesionados, obtendo resultados satisfatórios no que se refere a reorganização do córtex motor e na superação do não-uso aprendido.

Apesar de haver grande interesse na reabilitação pós AVC, ainda são poucos os estudos clínicos comprovados, randomizados e controlados sobre este assunto. De fato, a intervenção da fisioterapia minimiza consideravelmente a espasticidade, melhorando a funcionalidade e as atividades de vida diária do paciente, e é importante que seja aplicada de forma precoce.

\section{Referências}

BROL, A. M. Tratamento de restrição e indução do movimento na reabilitação funcional de pacientes pós acidente vascular encefálico: uma revisão bibliográfica. Fisioter Mov. Curitiba. v. 22, n. 4, p. 497-509. 2009.

DINIZ, L. Neuroplasticidade na terapia de restrição do movimento em pacientes com acidente vascular encefálico. Med Reabil. São Paulo. v. 22, n. 2, p. 01-2, 2003.

EKMAN, L. L. Neurociência fundamentos para a reabilitação. 3.ed. Rio de Janeiro: Elsevier, 2008.

GAMBA, R. T. Efeitos da terapia por contensão induzida em longo prazo em pacientes pósAVC. Rev. Neurocienc. São Paulo. v.19, n.4, p.735-40, 2011.

LIMA, E. C. B. A. Neuroplasticidade na reabilitação de pacientes acometidos por AVC espático. Rev Ter Ocup Univ São Paulo. set./dez. v.2, n.3, p.317-322, 2014.

MUSSE CAI. Protocolo clínico e diretrizes terapêuticas, espasticidade focal disfuncional, toxina tipo A de clostridium botulinum. Consulta Pública SAS/MS n. 11, p. 341-48. 2002.

OLIVEIRA, C. E. N. D. et. al. Fatores ambientais que influenciam a plasticidade do SNC.

Acta Fisiátrica, v.8, n.1, p.6-13, 2001. 


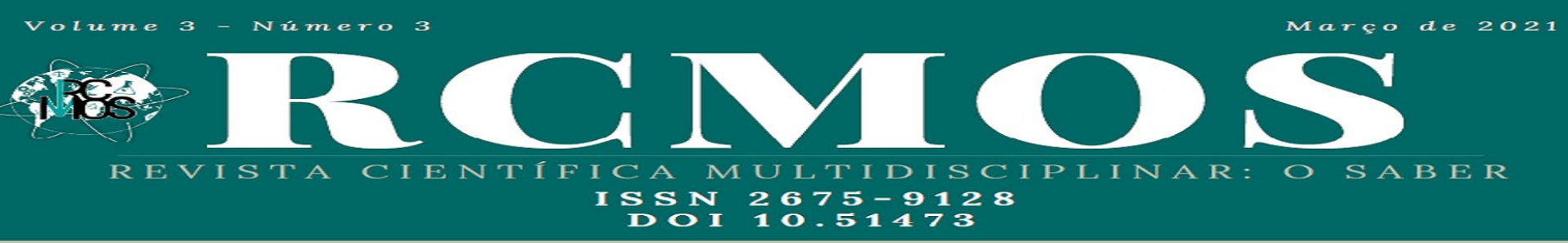

OLIVEIRA, C. E. N. D. et. al. Fatores ambientais que influenciam a plasticidade do SNC. Acta Fisiátrica, v.8, n.1, p.6-13, 2001.

PEREIRA, N. D. Uso de três princípios de intervenção aumenta a efetividade da terapia por contensão induzida: estudo de caso. Rev Ter Ocup Univ. São Paulo.2010. 


\title{
Votume 3 - Número 3 \\ "The impact of influencer marketing on destination choice-A quantitative study among Brazilian and German millennials."
}

Gleice Seibel $^{1}$

\begin{abstract}
The decision-making process of choosing a travel destination it is a very complex topic. Why individuals travel and what influences an individual's travelling intentions in general has been studied by different scholars. This study examines the differences in the effect of influencer marketing on cross-national consumption destination choices by focusing on the impact of influencer marketing on travel destination choices by German and Brazilian millennials. Influencer marketing is a relatively new topic and its main impact is still under evaluated. Tourist behavior theories have been the focus of much research in many tourism studies, but how German and Brazilian millennial travelers' intentions are shaped by influencer marketing has not been investigated. By reviewing academic sources, this master paper aims to analyze the efficacy of the TPB for predicting German and Brazilian millennial's intention when choosing a travel destination. Data were collected from Brazil and Germany for a two-week time frame starting in the beginning of June. 231 German, Brazilian and international tourists participated in the survey. In general, the main results have been aligned with previous literature studies which have supported the application of the TPB model. The three main elements, attitude, subjective norm and perceived behavioral control were observed to have made an effect. In addition, the findings indicated that internal and external factors are considered by German and Brazilian millennials when choosing a travel destination. Moreover, main implications, recommendations and suggestions for future studies have been provided in the last chapter of this study.
\end{abstract}

Keywords: influencer marketing. among Brazilian. German millennials

\footnotetext{
${ }^{1}$ Master Thesis at the International School of Management. Supervision Kim Hartmann; Prof. Dr. Matthias Lederer. ISM Campus: Munich 


\section{Volume 3-Número 3

\section{Sumário}

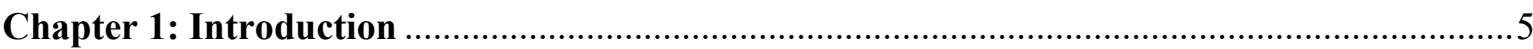

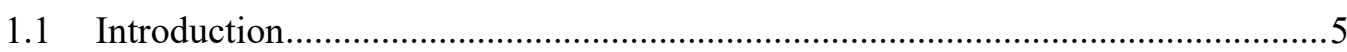

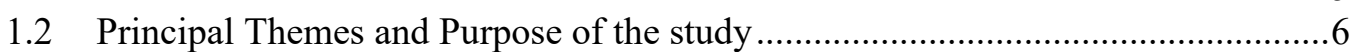

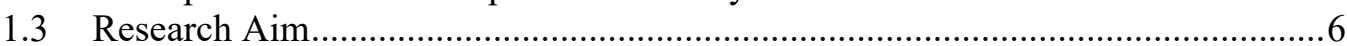

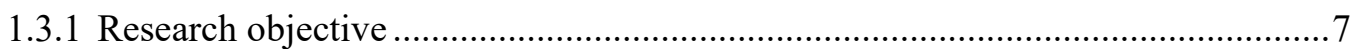

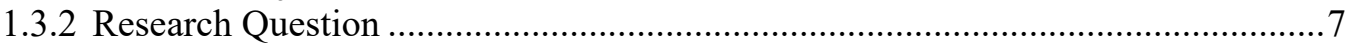

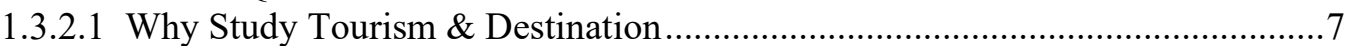

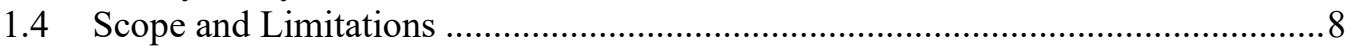

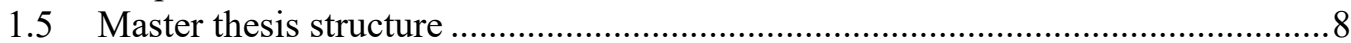

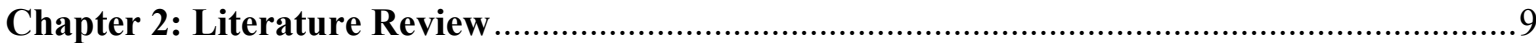

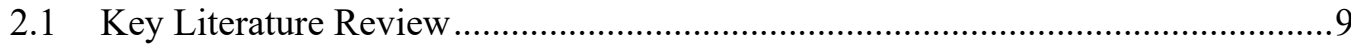

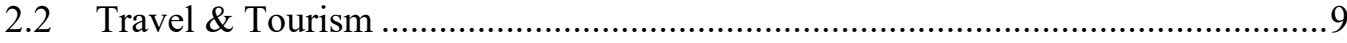

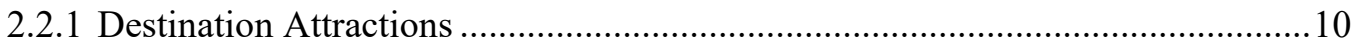

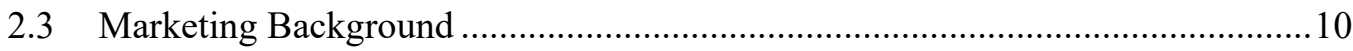

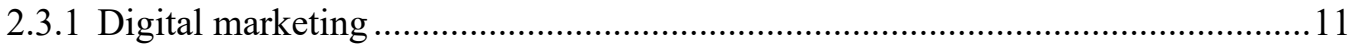

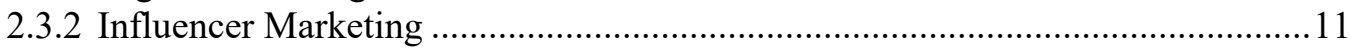

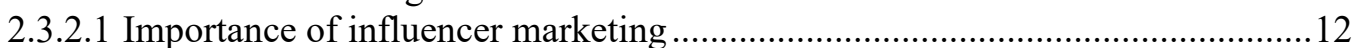

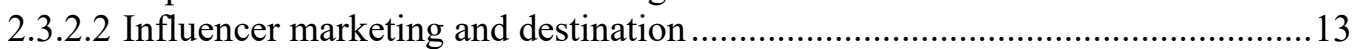

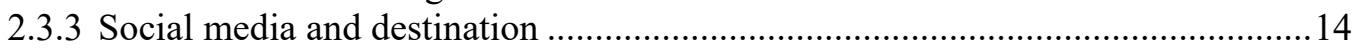

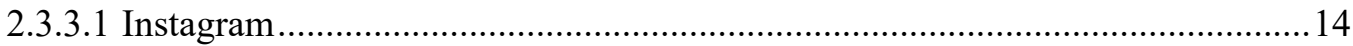

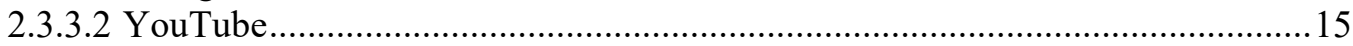

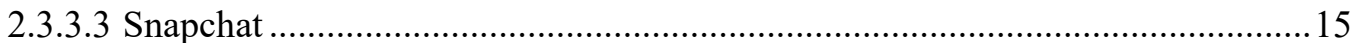

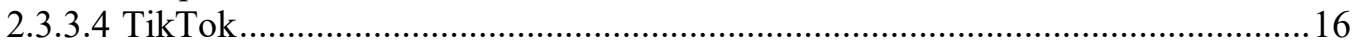

2.3.3.5 Importance of User-Generated content and destination ..................................... 17

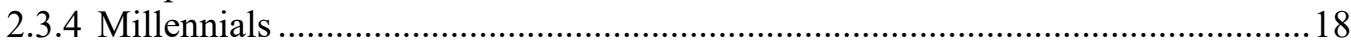

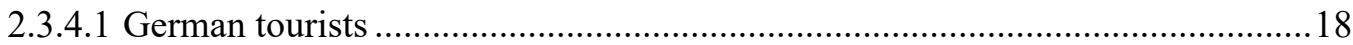

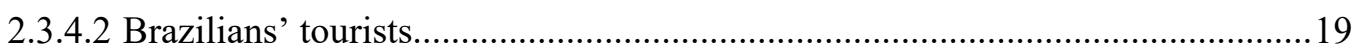

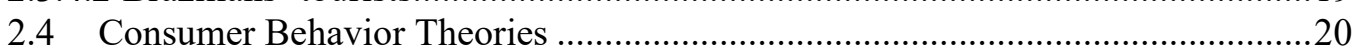

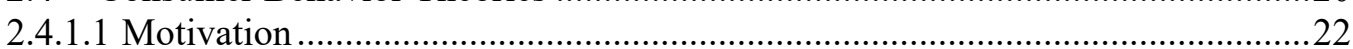

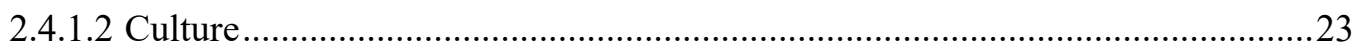

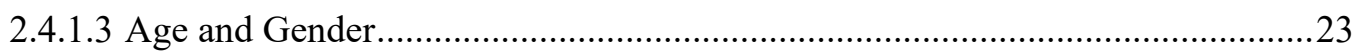

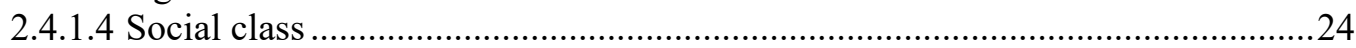

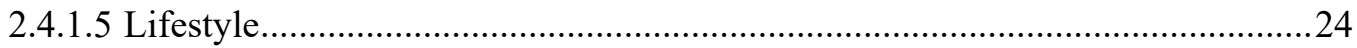

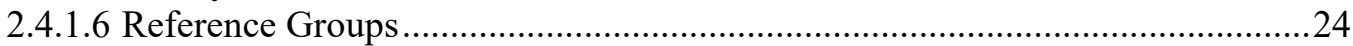

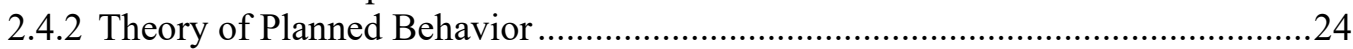

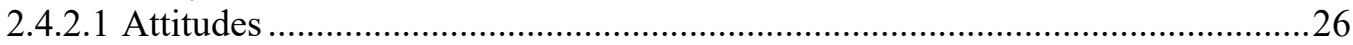

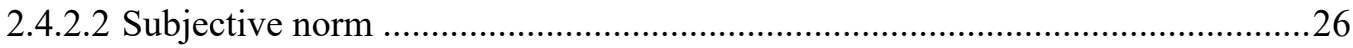

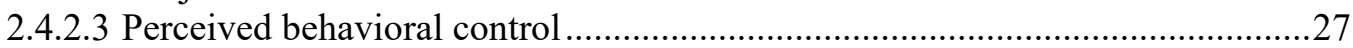

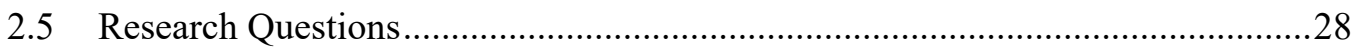

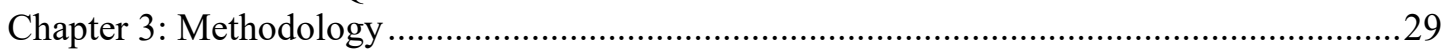

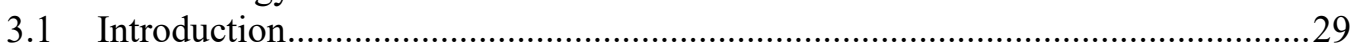

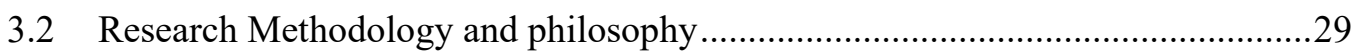

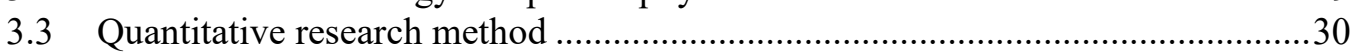

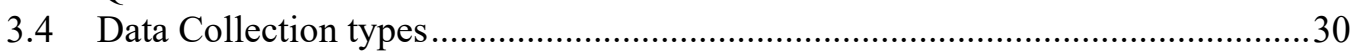

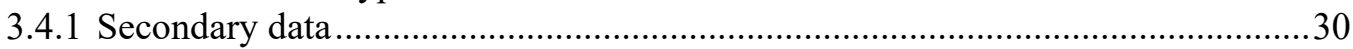

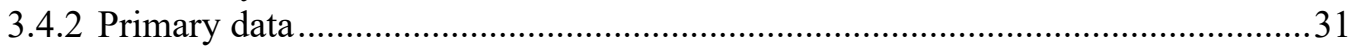

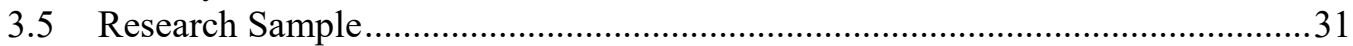

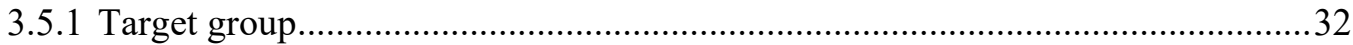

3.1 Survey 32

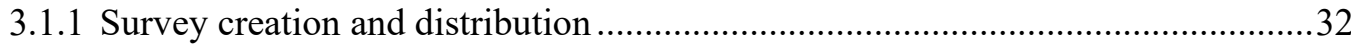

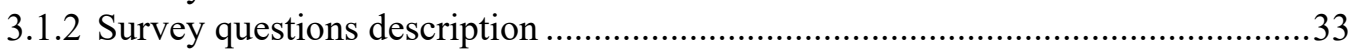


3.2 Research Ethics

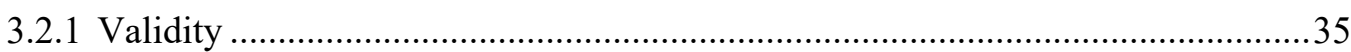

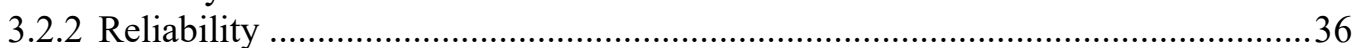

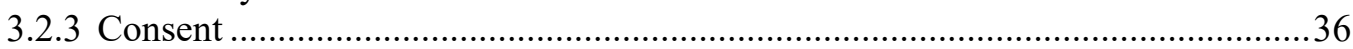

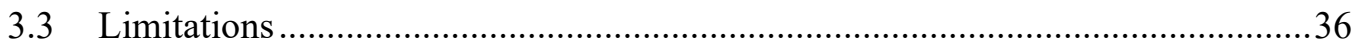

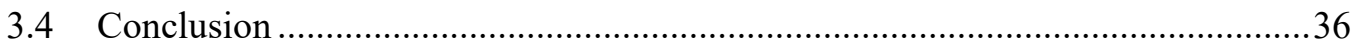

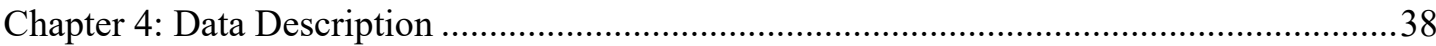

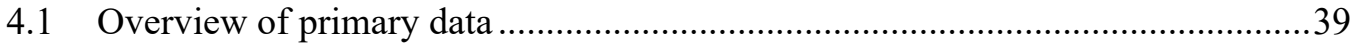

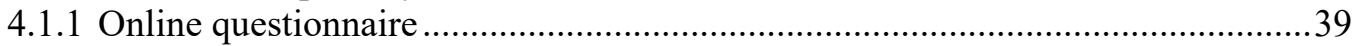

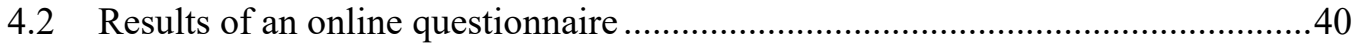

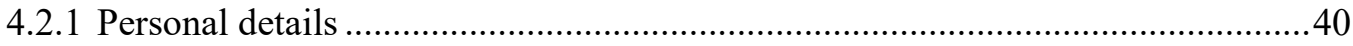

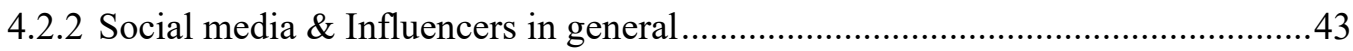

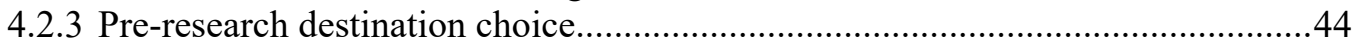

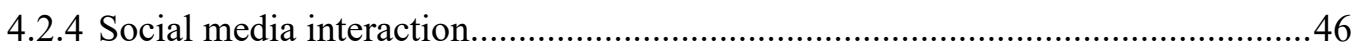

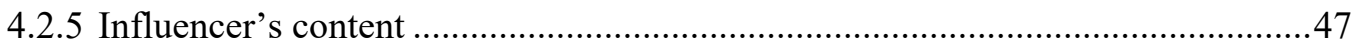

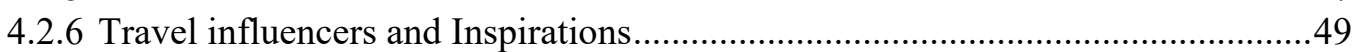

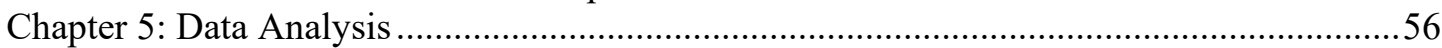

5.1 Do gender and nationality differ from social media time spending? ...................56

5.2 Where do German and Brazilian millennials look for their travel information? ..59

5.3 What are the main motives for German and Brazilian millennials to choose a

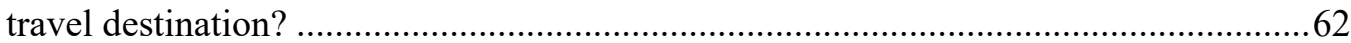

5.4 What are the main motives for German and Brazilian millennials to choose a travel destination?

5.5 What are the main barriers/factors for German and Brazilian millennials not to choose a destination?.

5.6 How German and Brazilian millennials interact in their social media on a travel destination? 71

5.8 How satisfied have German and Brazilian millennials been with Influencer

Marketing recommendations?

5.9.9. How often have German and Brazilian millennials posted their travel destination

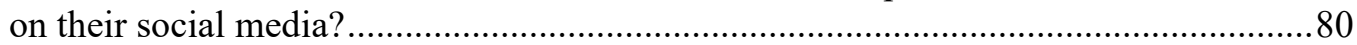

5.9.10. Why German and Brazilian millennials use social media? ................................ 81

5.9.11. German and Brazilian millennials trip preference? ..........................................82

5.9.12. Do travel influencer pictures impact German and Brazilian millennial's

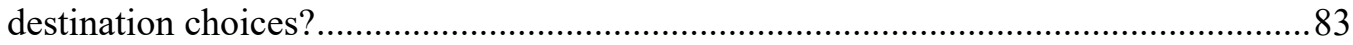

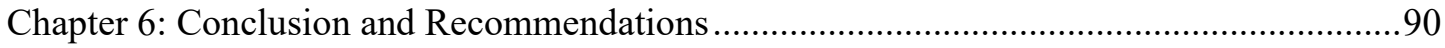

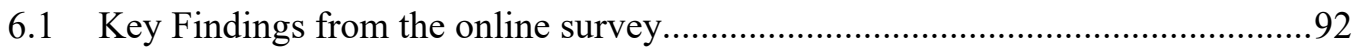

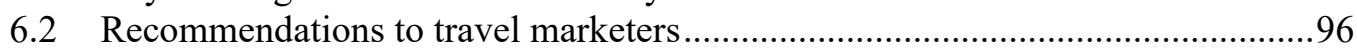

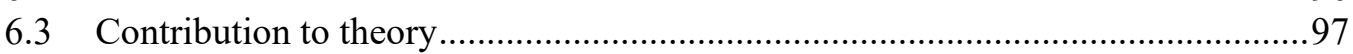

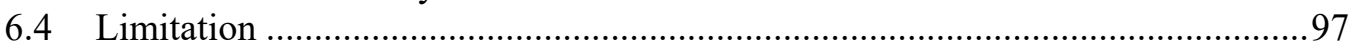

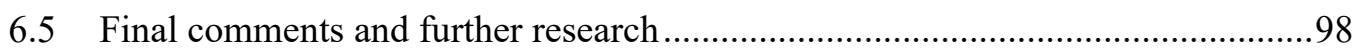

References 100

Appendix 110

A.1 Online questionnaire.

Further Declaration 


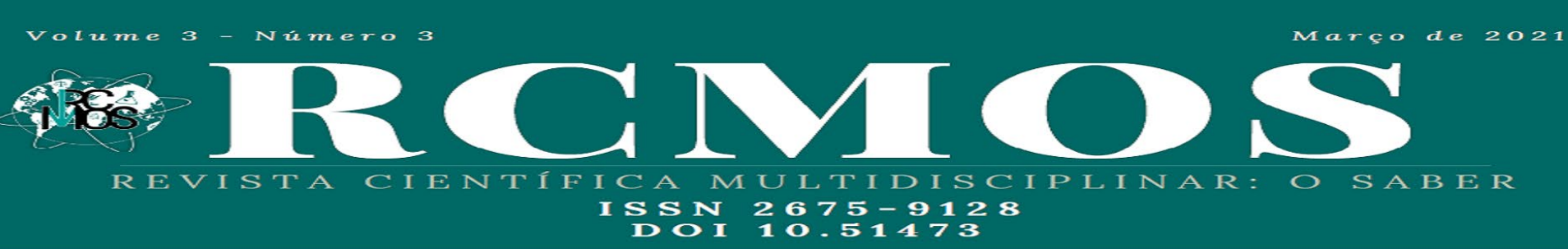

There is a broad body of consumers behaviour literature dealing with the purchase process of holidays. However, very little research has been conducted on examining differences in the effect of influencer marketing on cross-national consumption destination choices. Germany and Brazil are among the largest countries worldwide and very strong in the tourism industry. Both countries' tourism has been an essential source for their economy and millennials in both countries exercise powerful purchasing behaviour in the sector.

\subsection{Principal Themes and Purpose of the study}

Considering the continuous increase of social media usage on a global level, advertising on online platforms has become a valuable marketing tool for different businesses. (Statista, 2019 (a)). Among these online marketing strategies, influencer marketing has been frequently deployed in order to communicate with a wide array of customers.

Over the past decade, the travel and tourism industry has become a key sector in many different countries. The tourism industry contributed 8.8 trillion U.S. dollars to the global economy in 2018 (Statista, 2018 (b)). Germany is the highest-spending country in outbound trips in Europe with approximately 108.54 million trips (Statista, 2019 (c)). In 2017, Brazil, was the highest-spending country in Latin America, spending approximately 23 billion U.S. dollars in outbound tourism (Statista, 2019 (d)).

Brazil was the third place in Latin America, with the most significant international tourist arrival in 2018, with approximately 6.62 million tourists (Statista, 2019 (f)). Therefore, considering the popularity of the tourism industry among Germans and Brazilians, these countries represent attractive markets for in-depth research for relationship this master thesis is trying to test. In addition, with the aforementioned importance of the tourism industry for both countries' economies, it is essential to have a better understanding of both inbound and outbound consumer behavior and gain a better understanding of what influences their destination choices. Therefore, this master thesis aims to determine whether and how influencer marketing shapes the destination choice behavior of Germans and Brazilian millennials.

\subsection{Research Aim}

This study aims to explore whether Germans and Brazilians millennials' consumption destination choice is affected by influencer marketing. 


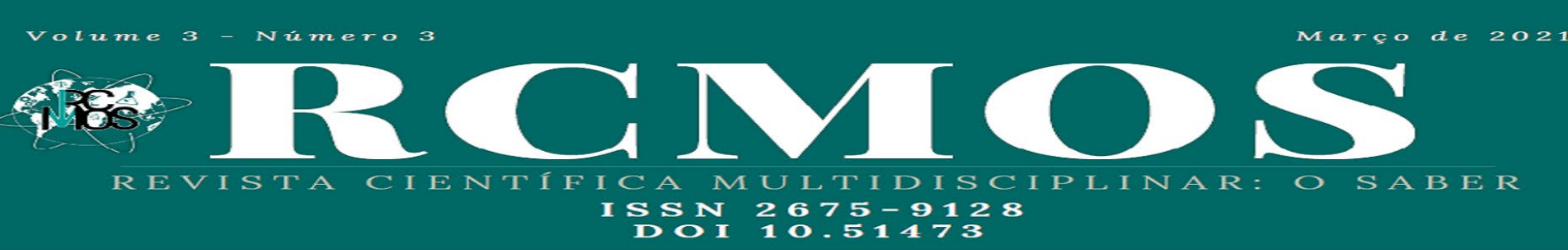

around creating unforgettable experiences for the tourist. In this scenario, having better knowledge of tourist's preferences helps with identifying better marketing strategies. Travelers are usually overwhelmed with different pieces of information and opinions when they are looking for a destination. Therefore, effectively promoting a destination is fundamental to creating a positive travel experience for the tourist. By giving the right information and providing reliable resources about the destination, marketers are able to better understand what kind of information will make a destination more attractive to a tourist and entice them to choose said destination.

\subsection{Scope and Limitations}

This master thesis will attempt to investigate and understand the role of influencer marketing with regards to destination choice among millennials. The literature on this topic is quite limited. While previous research by " (Tham, Mair, \& Croy, 2019) discusses the role of social media in destination choice, this master thesis contributes to the existing literature by discussing cross-national differences. Therefore, this master thesis aims to better under- stand the role of influencer marketing in influencing destination choice by focusing on the German and Brazilian millennial consumer markets.

\subsection{Master thesis structure}

The structure is essential to make research transparent, understandable, and direct. It will enable the researcher to present adequate literature, exploring analysis, and results at an adequate level. The structure of the master thesis is as follows:

Chapter 2, Literature Review: aims to give the background information of travel and tourism, destination attractions, millennials, influencer marketing, as well as engaging with the existing theory of planning behavior.

Chapter 3, Research Design: this chapter will provide the evaluation of the research methodology and justification of the quantitative approach in the form of online survey questions. In addition, it will consider the secondary data, primary data, sampling, ethical issues, limitations will be discussed and analyzed. In addition, it will be data analysis where the finding of primary data and online questionnaire results with charts will be analyzed.

Chapter 4, Conclusion and Recommendations: this chapter of the research will bring together the research findings and finally drawing a conclusion related to the research aim and objectives. In addition, it will provide recommendations for future research. 


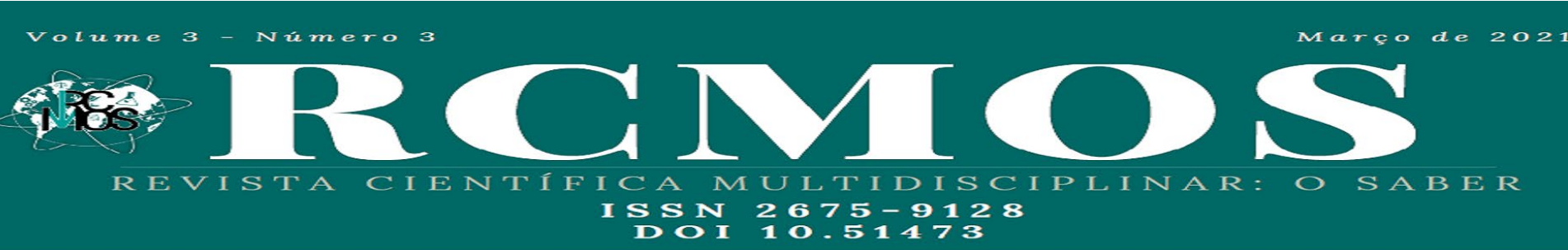

\section{Chapter 2: Literature Review}

\subsection{Key Literature Review}

This chapter will give theoretical background and information on the crucial topics that are important for this study. Tourist behavior has been, for many researchers, an essential issue in the travel and tourism literature. First, an overview and background information about travel, tourism, and destination attractions will be given. Second, German and Brazilian tourists will be defined and their differences discussed. Thirdly, an analysis of millennials will be carried out from a marketing perspective. Fourthly, the concept of influencer marketing and social media are explained within the context of this study. Fifth, factors affecting consumer behavior are addressed. Sixth, the consumer buying process that will help broaden the knowledge of consumer behavior and the purchase decision-making process is also addressed. The application of the Theory of Planned Behavior (TPB) in tourism is explained in order to identify consumer behavior in the destination choice context.

\subsection{Travel \& Tourism}

Tourism is one of the world's more substantial economic drivers, creating employment and unlocking regional development (Guerreiro, 2019). According to United Nations World Tourism Organization (2010), tourism is "social, cultural and economic phenomenon that create the movement of people to countries or place outside their usual environment for either personal or business purposes" (United Nations, 2010). The global travel and tourism industry has reported a rise in $3.9 \%$ of its contribution to the global economy, totaling $\$ 8.8$ trillion (WTTC, 2019). In addition, it has created 319 million jobs in 2018 and represents $78.5 \%$ of leisure spending. Travel and tourism have been instrumental for continued eco- nomic development and improvements on infrastructure, helping many local communities around the globe (OECD, 2020). Due to the increase in income around the globe, consumers are changing habits in consumption. This rise in global income levels, paired with higher awareness of domestics and international tourism opportunities contribute to the rise in tourism travel. The increased usage of internet and communication technologies has changed the tourism industry. Cheaply and readily available information online, when paired with global improvements in transportation infrastructure and lower travelling costs, gives people more options for traveling. In addition, the increase in accommodation and transportation types has given a wide range of 


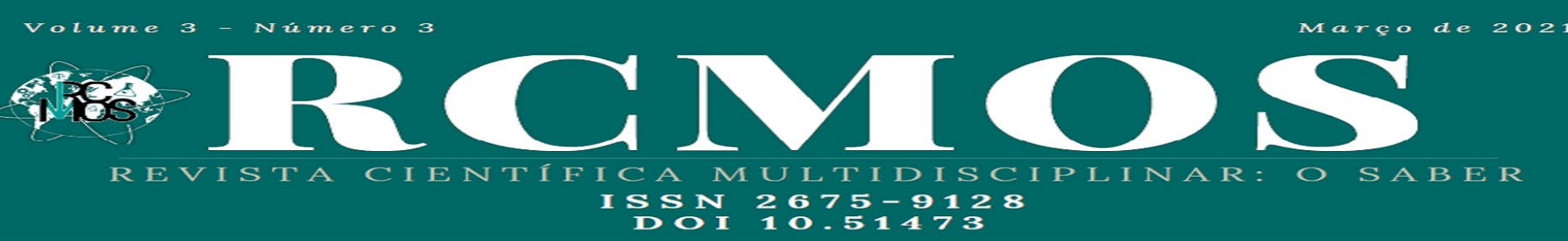

Marketing is defined as the process by which organizations build value for customers and create a relationship with them in order to attract and obtain customer values in return (Kotler \& Gary, 2016). Marketing has been an essential element for any business' success. It is also defined as the process of creating communication, delivering, and exchanging offerings that have value for customers (Middleton \& Fyall, 2009). Various marketing strategies have been developed in order for organizations to collaborate with their customers. Advertisement is defined as the insertion of a promotional message in a communication vehicle in the exchange for payment. This has embodied the traditional marketing approaches, which include advertainments in television, radios, and print media advertising (Blythe, 2009). Another traditional marketing approach is word of mouth (WOM), which has been of the most efficient form of marketing. WOM is defined as informal communication between people or customers where information on the evaluation of a particular product or service is exchanged (MacGeorge \& Swol, 2018). Relationship marketing is the ability for organizations to provide superior value to their customers by improving product quality, supporting services that improve customer satisfaction that can result in customer loyalty (Ravald \& Grönroos, 1996).

\subsubsection{Digital marketing}

Digital marketing is defined as the use of technology and the internet to create communication that helps a business gain and retail customers while forming relationships with them (Wymbs, 2011). With the increasing popularity of online social media platforms, digital marketing has leveraged the large share of online interactions in order to serve customers. Therefore, digital marketing has been increasing its popularity among marketers. There are several digital marketing types. Search engine optimization (SEO) is a visibility-enhancing process that is not paid (organic). It involves optimizing a website's position in search engine results by including specific popular key-words related to the website's content in the web- site text (Lee \& Jang, 2016). On the other hand, Search Engine Marketing (SEM) involves payment in order to increase traffic. Social media marketing is carried out by interreacting with customers with different social media platforms.

\subsubsection{Influencer Marketing}

Influencer marketing is one of the newest types of digital marketing that is increasing in popularity among marketers (Chaffey, 2016). Influencers are people that are popular in different social media platforms like Facebook, YouTube, and Instagram. Influencer marketing involves 


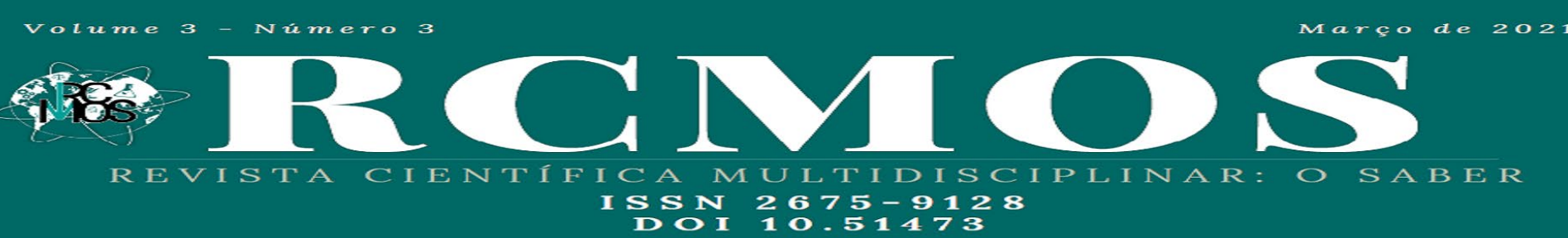

calculated on a global scale. The organization has an absolute power to control its influencer by adequately making plans of what to post and continuously communicating with its influencer based on the instantaneous feedback by followers. This continuous feedback helps organizations interfere, implement, and spontaneously generate marketing strategies.

Influencer marketing is flexible in the sense that influencers can quickly switch their posts and stories, which gives this form of advertisement a competitive advantage. In a world of rapidly-changing trends, influencer marketing allows brands to project a brand image that is in tune with current trends while also avoiding the internal bureaucracy that the traditional endorsement would have to pass through.

However, it is essential to be aware that influencer marketing, like any other marketing strategy, has its drawbacks (Pfund, 2019). High Cost is one these drawbacks, meaning that the organization needs to be financially stable to support a high investment. The online proliferation of fake news has also been very damaging to specific brands. In addition, some digital influencers have acquired fake followers, where individual accounts on social media have paid to gain a higher number of followers rather than gaining a real audience. There- fore, these accounts will not influence the brand target audience and the product or service will not be noticed as was planned. In addition, influencers who post too much on social media (also known as spamming) can be annoying for the audience, who can get over- whelmed with the sheer amount of advertisements. This can lead to the audience quickly unfollowing the influencer if it is not satisfied the content. Therefore, it is necessary for brands and organizations to adequately plan what and how many times an influencer should post.

\subsubsection{Influencer marketing and destination}

Due to the higher competition among different industries such as fashion, food \& beverage, tourism, and hospitality, it has become difficult for tourism marketers to create a strategy that will retain their existing customers. Information gathering and evaluation have become an essential part of the tourist choosing a destination (Karamehmedović, 2019). Information search includes internal and external information. The internal information is based on previous experiences and the long-term memory of an individual regarding the experience and feelings he or she had about going to this destination.

The external information from the destination will be based on the media, family, friends, travel agencies, social media. For example, if the individual traveled to a destination be- cause he or she followed an influencer and was satisfied with the trip, it is more likely that 


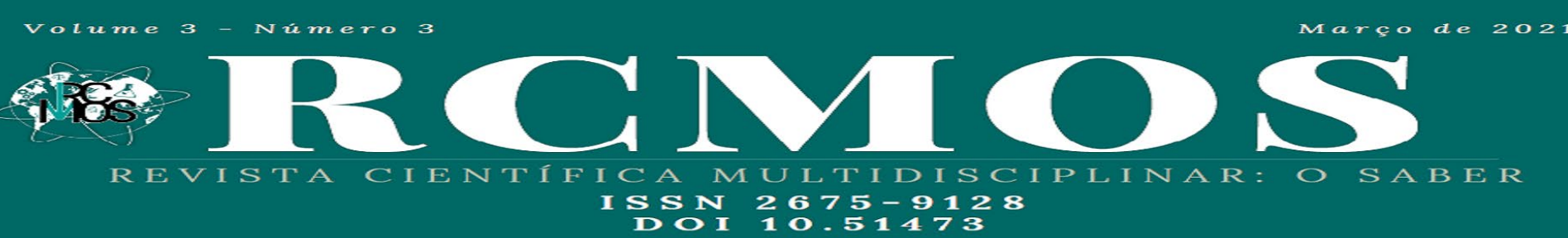

that their consumers' primary interest in social media platforms is to collect information, share, and to gain advice; $64 \%$ of their respondents used social media to make their travel plans decisions. Therefore, social media plays a major role in the decision-making process of travelers to obtain travel-related information and share their experience. The opinions of another individual highly influences consumers' purchasing de cisions in a social media context.

For the purpose of this thesis, it is important to acknowledge the number of social media usage both in Germany and Brazil. Of German millennials aged between 18 and 35, 89. 2\% use social media frequently (Koptyug E., 2019). Of Brazilian millennials aged 18 to 35, approximately 45\% of users of social media in 2019 (Statista, 2019 (1)). Therefore, this shows that both in Germany and Brazil, social media usage is high among millennials.

\subsubsection{Importance of User-Generated content and destination}

In the past years, consumers have increased their usage of the internet to find information about a product or service (Burgess \& Sellitto, 2009). User-generated content (UGC) is media related content that is created from consumers rather than from paid brands that are shared on the internet (Daugherty \& Eastin, 2008). UGC is also essential on social media platforms. UGC is any content such as pictures, videos, discussions in posts created by customers or users of an online platform that is publicly available to other customers. The advancement of Web 2.0 technologies such as social media platforms has increased the consumption of UGC. Many websites have allowed and incentivized consumers to create content and share it on their website. UGC can be seen as a type of electronic WOM marketing where people can share their opinion about the product and service. Furthermore, UGC on social media helps to facilitate users' interactions with each other by giving travel information that will help them make a decision on their travel plans. For example, if a consumer wants to read about the experience of the other UGC user destinations, the consumer will get in touch with the other user and they will interact with each other. Therefore, it is important that destination marketers leverage their consumers as part of their influencer marketing strategies (Wiley, 2019). Influencers have used contests among their followers to share their travel experience, the place that they wished to go. In addition, an influencer can ask a question about what they like when they are traveling. Influencer marketing has the possibility to persuade and encourage consumers to share images, videos, and stories. This gives the marketers and organizations a better overview of what their target consumers looking for in terms of experiences. Moreover, social media is not only used to gather travel information but also to 


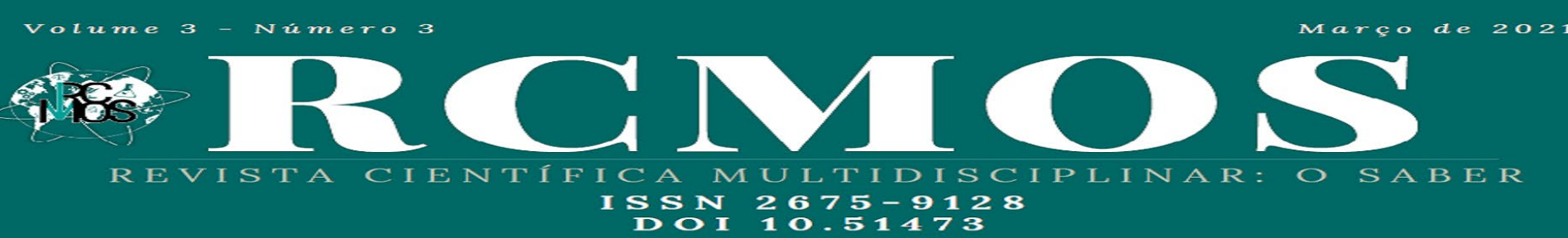

gross monthly earnings of a full-time employee in the same year were 3,880 euros. In 2018 the number of holiday travelers in Germany reached a record high compared to previous years. Tourism in Germany has continually grown over the years, with domestic tourism accounting for 185.1 million arrivals to Germany in 2018 and 332.6 million overnight stays in Germany (OECD, 2020). German people also are some of the top spenders in foreign travel (approximately 65 billion in a year). (Telegraph, 2017). Approximately 12\% of German tourist's travelled to East Asia and North America in 2018. Germans' passport holders enjoy the advantage of having a sizeable amount of visa-free travel options to 188 countries around the globe. However, Germans do not only like to travel abroad, but they enjoy traveling in their homeland to cities like Berlin, Munich, and Hamburg. In summer, the Baltic Sea coast attracts many Germans tourists. In winter, the Southeast attracts many Germans tourists that enjoy ski and snowboarding in some of the largest ski resorts world- wide. As Germans are very fond of a warm climate, their favorite international destinations include Spain, Italy, and Asia. When vacationing, German holiday goers have a penchant for spending time in nature. Therefore, they tend to prefer hiking, beach or bathing, city breaks, cruises, and cycling trips. For the purpose of this study is important to have an overview of the holiday preferences of German millennials. A recent survey of German millennials on their preferred type of vacation travel shows that, among those aged from 18 to 35 years, approximately $43.1 \%$, went to a beach holiday in 2018 (Statista, 2019). It is important to place these travel preferences within the context of the average income and purchasing power of German millennials: Statistics show that $18.8 \%$ of millennials between the ages of 18-35 receive a net income between EUR 1,000 and 1,500, and only 4\% reported a net income between EUR 2,500 and 3,000 (Pwlik, 2019).

\subsubsection{Brazilians' tourists}

Brazil has a population of 208 million people (BBC, 2019). Brazil is one of the most significant and influential countries in South America, increasing its economic power. However, the gap between rich and poor remains quite large. Approximately 50\% of Brazilian population has an online presence, as the country has become a key player in social media consumption and presence. Tourism in Brazil is one of the most important sectors for the economy, accounting for 3.1\% of GDP in 2018 (OECD, 2020). Tourism in Brazil has been essential for the creation of business, helping to increased production of goods and services and bringing with its infrastructure developments to the local communities. In addition, in 2019, the tourism sector was responsible for 7.4 million jobs (WTTC, 2019). In 2018, inter- national 


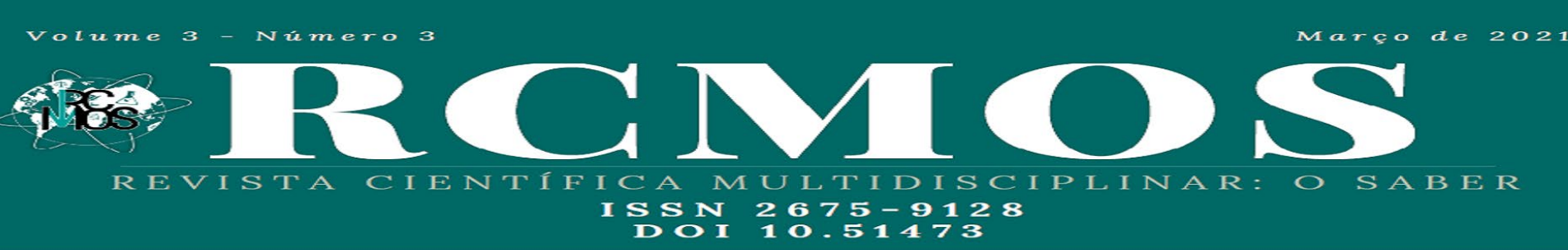

tourist arrivals were approximately 6.6 million. Despite an unemployment rate of $12 \%$, (World Bank, 2020) travel is an essential item for Brazilians, even in times of crisis. Brazilians adapt the itinerary to their pockets, but do not give up on a few days off (Catraca, 2019). Despite its important status for Brazilians, travel demand among Brazilians is restricted by a number of important factors, such as the rise in the dollar, exchange rate in- stability, and political issues. In addition, while 5 million (77.1\%) of passenger departures went to destinations within Brazil, the number of Brazilians choosing international travel destinations has increased. In 2018, 1.5 million (22.9\%) of Brazilians travelled abroad, against 1.2 million in 2017, demonstrating a $23.3 \%$ increase.

For tourist destination preferences within Brazil, the Northeast continues to lead, receiving $51.8 \%$ of the total number of passengers arrivals. When it comes to international outbound destinations, Brazilian people favor the United States and Europe (OECD, 2020). In this context, it is important to highlight that Brazilian telenovelas influence Brazilian tourist destination choice (Diario do Turismo, 2018). Studies have shown that when a given telenovela is on air, there is an increase in the number of searches related to a particular location portrayed in the telenovela. Brazilian tourists' activity preferences tend to be in the areas of history, sightseeing, gastronomy and shopping (Xavier, 2019). This latter preference is explained by the high prices of import goods such as clothes and electronic products in Brazil. The Government imposes a high tax tariff on a number of import goods in order to increase demand for national products among Brazilians. Therefore, this leads to many Brazilian's travels abroad for shopping (The Economist, 2013).

Furthermore, the minimum wage in Brazil is about BRL 998 (approximately EUR 179) (Pasquali, 2019). Approximately $50 \%$ of the Brazilian population are millennials. Regarding the professional activity of Brazilian millennials, $45 \%$ are employed, and $47 \%$ earn between 1 and 4 minimum wages (Gil, 2019).

\subsection{Consumer Behavior Theories}

Tourism marketing research has focused on exploring travel behavior and destination de- mand and choice. Destination choice is one of the most frequent topics of research related to consumer behavior in tourism as it is associated with the creation and maintaining a high demand for destinations. Destination marketers and tourism service marketers are con- fronted 
daily with different issues of consumer behavior (Caldito \& Frederic, 2015). Consumer behavior is defined as the activities that individuals undertake when searching, attaining, and consuming a product or service (Sethna \& Blythe, 2016). The primary focus of research on consumer behavior is to understand how purchasing decisions are made and how they can be influenced in order to optimize interventions to garner desired results (Swarbrooke \& Susan, 2007). In the tourism context, it will help effectively define whom to target, at what particular time and to what particular destination. More importantly, it will assist in persuading consumers to choose a certain destination that is designed to meet their particular needs and wants. In addition, it will improve the development of effective strategies and satisfied customers. Therefore, it is fundamental for marketers and marketing organizations to understand customer behavior, and more unusually, tourist behavior. In order to implement adequate marketing strategies in the tourism context, it is essential to understand the motivational factors behind travel decisions, the impact of attitudes on destination choice and how different reference groups influence individual travel decision-making. Factors influencing consumer behavior

Most tourism and hospitality companies have an inadequate understanding of their consumers, and many do not adequately monitor consumer behavior at the necessary level to remain competitive. Due to the ever-evolving economic, societal and environmental shifts, consumer behavior has also changed. Consumers have become more demanding, in- creasing competitive pressures on organizations. In this context, it is essential to understand the different factors that influence tourists to choose a particular destination.

Figure 1: Factors influencing Consumer Behavior (Hudson, 2008). 


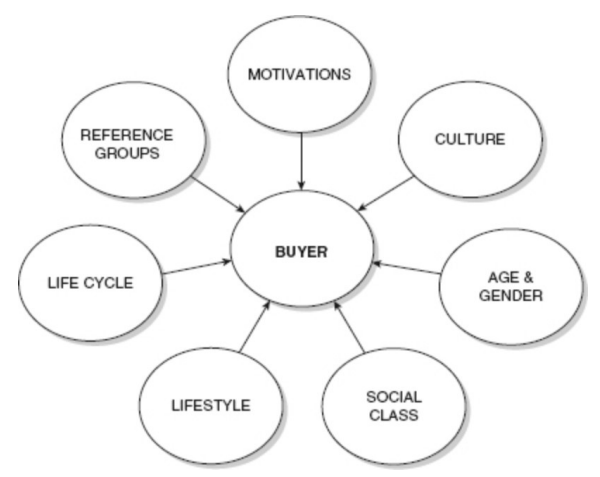

Source: Hudson, 2008

Figure one shows the main factors that influence consumer behavior (Hudson, 2008). Motivation is often seen as the main decisive factor of consumer behavior. However, cultural, personal, and social influences also have an importance on consumer behavior decision making.

\subsubsection{Motivation}

There are two main ongoing topics of discussion within tourism research: The motivation for travel and the behavior traveler process (Hsu \& Songshan, 2012). Motivation is an internal drive that makes individuals take a particular action to satisfy their needs and wants. There are multiple possible travel motivators, including the chance to share enjoyable memories with family and friends, the chance to escape from one's daily work and home routine, the opportunity to explore new places and cultures, to rest, to do specific sport or activities, etc. (Caldito \& Frederic, 2015). The motivation concept has been widely used to predict tourist choice of traveling behavior. Therefore, it is essential to know the motivation of tourists as this is a useful source to establish an appropriate destination and effectively use the resource of tourism to meet tourism expectations, desires, and needs.

The tourism research motivation approach is divided into two forces that indicate that individuals travel because they are pushed and pulled towards some factors (Yoon \& Uysal, 2005). Push factors are the wants and needs to travel, i.e., the main reasons why individuals choose to leave their home and daily routine. Pull factors are the reasons for going to a particular destination. Push factors are concerned with the socio-psychological constructs of the individual's environment that lead them to travel by influencing their decision to travel. On the other hand, pull factors consider the attractiveness of a given destination, and how this attractiveness impacts on destination choice. 


\section{Volume 3 - Número 3

\subsubsection{Culture}

A growing body of literature has sought to understand cultural differences in consumer judgment and decision-making in order to appropriately develop culturally-sensitive marketing communication strategies (Sharon \& Angely, 2015). Culture is defined as the beliefs, norms, and rituals of an individual that influence their consumer behavior (Shavitt \& Cho, 2016). Culture involves the general goals individuals have, how they respond to prices, brand images, and marketing advertising forms. These different cultural factors influence how human beings live, communicate with each other, think about particular things, and how an individual will respond to a specific situation. Usually, for self-image and satisfaction, individuals will satisfy their needs and desires that will fit in their social norm's environment. For example, it might be less acceptable to drink, kiss, and party in public in a Muslim- majority country, whereas many of these behaviors would be considered acceptable on the other side of the globe in South America.

Furthermore, the influence of culture on purchasing behavior is different from country to country. Therefore, it essential for marketers to identify and analyze the culture of different countries, regions, and groups (Tyagi, 2018). It is also important to consider the role of subcultures, which can exist within different nationalities, ethnicities, religions, and regional geographic particularities. Taking these factors into account will help to design specific destinations according to the needs of a certain geographical group.

\subsubsection{Age and Gender}

Age impacts the consumer's purchasing behavior, as an individual's purchasing patterns and preferences will change over the years (Tyagi, 2018). Historically, market segmentation was carried out by age group (Hudson, 2008). In the past years, the senior market was the main target by marketers as this age group spent the most on travel, was less price-driven and took longer trips, making them more profitable. However, due to the increased travel demand from younger generations, marketers had to adapt their marketing strategies to younger people, who are price-driven and have different expectations in relation to their destinations compared to seniors. Furthermore, gender influences consumer behavior as the roles and responsibilities varies between men and women. In addition, the expectation, characteristics, attitudes, and behaviors of men and women are time-variant and culture-specific. Therefore, it is essential to understand that men and women are more likely to want different products or services as they have different ways of liking and purchasing them. Gender difference in consumer behavior is 


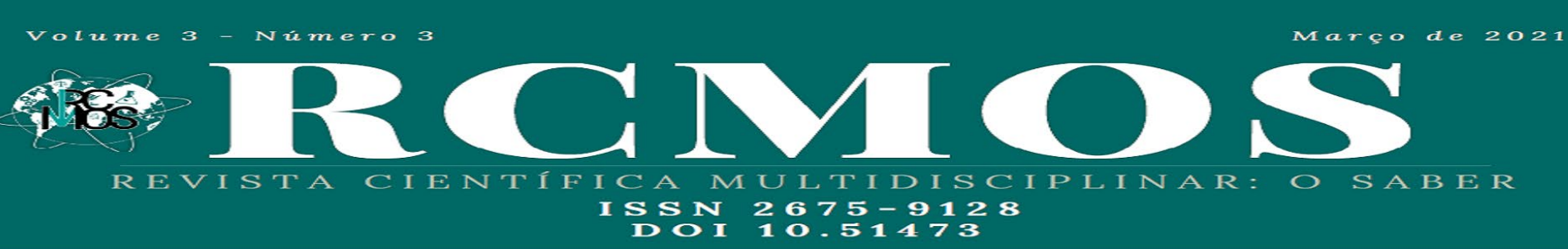

fundamental to develop a strategy that will satisfy both men and women to choose their wants and needs of a destination.

\subsubsection{Social class}

Social class is another important external factor influencing consumer behavior. It is important to note the social class an individual occupies in society, which is determined by factors such as income, occupation, wealth, education. Marketers have assumed that individuals of one class buy products and services for different reasons than individuals in another class. This can be interpreted as higher-income consumers being more likely to travel to certain destinations that will be "too expensive" for other social classes. If the income is higher, an individual is more likely to travel often and to choose more luxurious destinations. For example, a German with a higher income is more likely to choose to travel to Ibiza or Mykonos whereas a German with a lower income is more likely to travel to Mallorca or Barcelona.

\subsubsection{Lifestyle}

Tourism marketers have further segmented their target markets by consumer lifestyles as this determines the ways in which individuals allocate time, money, and energy. Lifestyle helps to measure and provides an understanding of consumers based on their way of living, which is interrelated with the types of vacation these individuals choose (Chen \& Huang, 2009). The lifestyle approach can help to identify consumers into different groups and de- fine the demand and needs of the groups in order to identify a destination that best fits the group. Therefore, analyzing consumer activities, opinions, interests, and lifestyles will provide essential information that can influence consumer destination choice.

\subsubsection{Reference Groups}

Reference groups influence the development of an individual's attitudes or behavior (Tyagi, 2018). These groups are made of people such as family members, friends, and work col- leges. These reference groups influence the individual by shaping expected norms and roles, resulting in the individual behaving a certain way.

\subsubsection{Theory of Planned Behavior}

Understanding tourism behavior and destination choice intention is crucial in the tourism management industry (Juschten \& Pürrer, 2019). As tourism requires tourists, it is 
crucial to gain information about tourist behavior and tourist expectations and desires when choosing a destination (Ziadat, 2015). In order to investigate the complex process of destination choice, this study will apply the theory of planned behavior (TPB) model to help to predict the intention behavioral of a destination travel choice. The TPB model is one of the most discussed approaches to anticipate human behavior in the tourism and marketing industry (Hsieh \& Park, 2016). Furthermore, the TPB has been useful in various tourism choices such as accommodation, travel, environmental, and destination choice. Ajzens (1991) developed the TPB model as an extension of reasoned action (TRA). The TPB purpose is to look in-depth within the individual intention and interpreted how behaviour is created (Ajzen, 1991). According to Ajzen (1991), intentions were interpreted as the factors that motivate a particular behaviour.

According to Jalilvand and Samiei's (2011) research, the TPB model provided an interpretation of the process of travel destination choices (Jalilvand \& Samiei, 2012). The TPB model suggest that individuals are more likely to behave in a certain way if they believe that behavior will conduct to a conclusion that they value significantly. (Quintal \& Lee, 2010). The TPB approach has been implemented in various areas, such as the food and health industry. However, the existing literature within the tourism industry has been constantly implemented in order to better analyse and predicate consumer behaviour towards choosing a particular destination (Martin, Ramamonjiarivelo, \& Martin, 2011). Therefore, using the TPB will provide more knowledge and predict an individual's location choice. TPB is made of three main elements: The attitude, subjective norms, and perceived behavioural control which each influence the intention of the individual to perform a behaviour.

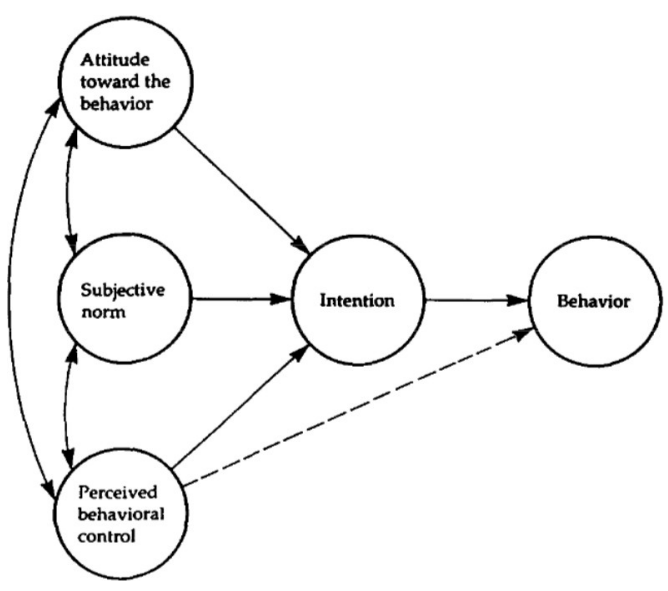

Figure 2: Theory of Planned Behavior (Ajzen, 1991).

Source: Ajezen, 1991 


\subsection{Research Questions}

Therefore, based on the literature review, a number of fundamental questions need to be answered and analyzed better to understand the impact of influencer marketing on destination choice. Based on the critical review of the relevant literature, the following research questions, which will be addressed by the methodology, have been identified:

These questions had addressed throughout the following methodology.

1. Do gender and nationality differ from social media time spending?

2. Where do German and Brazilian millennials look for their travel information?

3. What are the main motives for German and Brazilian millennials to choose a travel destination?

4. What are the main barriers/factors for German and Brazilian millennials in not choosing a destination?

5. How do German and Brazilian millennials interact in their social media on a travel destination?

6. How trustworthy is Influencer Marketing for German and Brazilian millennials?

7. How satisfied have German and Brazilian millennials been with Influencer Marketing recommendations?

8. How often have German and Brazilian millennials posted their travel destination on their social media?

9. Why do German and Brazilian millennials use social media?

10. What are the trip preferences of German and Brazilian millennials?

11. Do travel influencer pictures impact German and Brazilian millennial's destination choices? 


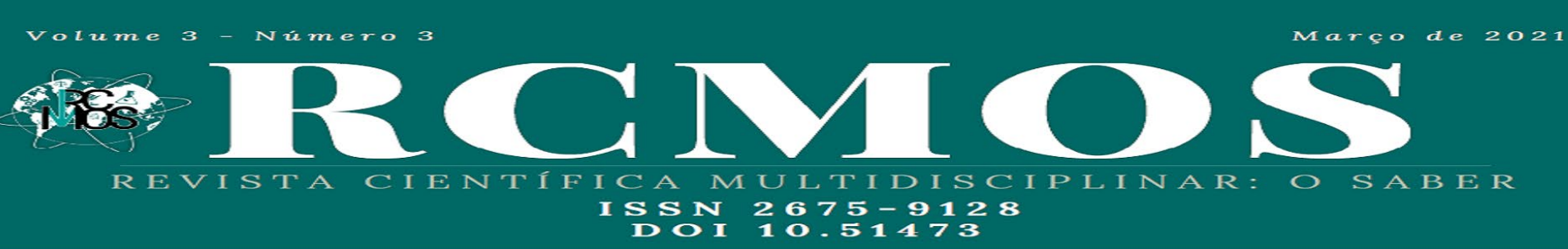

The research for this study was conducted to find and gather data about German and Brazilian millennials' travel decision choices throughout the survey questions. Therefore, based on the above options, the quantitative research approach is most suitable for data collection and analyses for this study.

\subsection{Quantitative research method}

The researcher has chosen to use a quantitative research method for this thesis. The main objective was to identify and measure how many German and Brazilian millennials allow influencer marketing to impact on their destination choice. Therefore, the quantitative method is the most appropriate as this study gathers data information from survey questions to gain personal responses from German and Brazilian millennials. After the collection of information from the survey responses it will be transformed in "data" (Bryman \& Bell, 2011). Most of the information from the survey will be based on people's age, number of times a destination was booked because of influencers, how frequently social media is used. This will then be translated into numeric form in order to facilitate data analysis. The numbers will help the author to interpret and better understand the results.

\subsection{Data Collection types}

Throughout this dissertation. a mixture of primary and secondary data is used to answer the research questions. Primary data collection was used to test the hypotheses derived from research questions, whereas secondary data was collected for the purpose of conducting the literature review, informing the formulation of research questions and interpreting the results of the survey data. The mixture of primary and secondary data helps the researcher gain new insight information and knowledge from multiple sources (Axinn \& Pearce, 2006).

\subsubsection{Secondary data}

The secondary research was undertaken by reviewing the literature of topics related to the research study. The use of secondary data is essential for research papers, as reviewing existing data contributes to the formulation of a cohesive body of background knowledge with existing theories upon which the current research question is based. Apart from informing the research question, the existing body of knowledge and data also serves as the basis for the contributions of this dissertation, expanding the frontier of knowledge. For the purpose of this dissertation, secondary data offers existing theories on consumer behaviour, decision-making, 


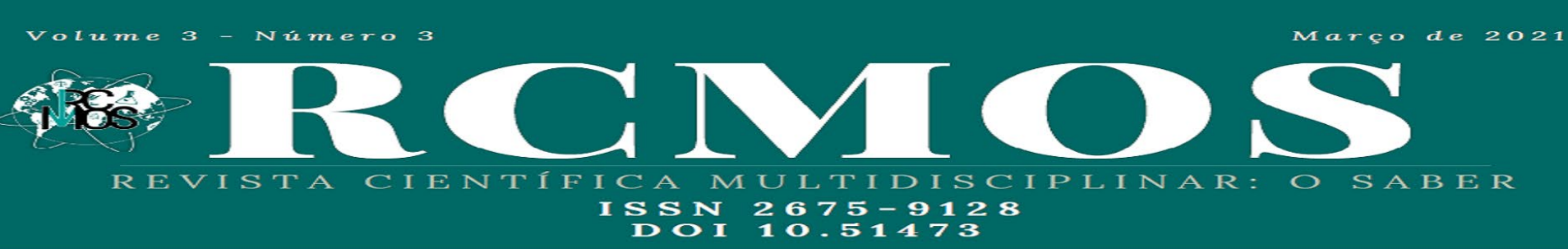

is known as the sampling (Clow \& James, 2014), (Murray \& Ambrose, 2006). The sampling method is crucial for the quality of the findings and accuracy. Therefore, for this study, the sampling group is focused on the German and Brazilian millennials generation, which comprises people aged 18-34. As this age group is interacting more on social media and use social media the most, they are more likely to follower influencers on their social media.

\subsubsection{Target group}

In order to gain specific data findings, it is essential to study a particular population to obtain relevant data. Therefore, the leading target group was young adults between the ages of 18 and 34 (known as "millennials or Y-generation"), who are from Germany or Brazil and are active on the internet, particularly on social media. The researcher chooses the millennial generation as the primary target group due to the fact that $62 \%$ of social media users are younger than 34 years old. People in this age group are also most likely to be influenced through their social media when it comes to travelling decisions. The author chose to com- pare the German and Brazilian millennials in a survey in order to gain information about different cultural preferences and to provide suggestions and recommendations for marketers seeking to target this demographic.

Furthermore, the author chose not to limit survey responses to people using social media, purposefully including answers from users that do not use social media when it comes to investigating people's travel and information search behavior as well as their attitudes towards influencer marketing.

\subsection{Survey}

The survey is one of the most effective methods for quantitative research (Bell, Bryman, \& Harley, 2015). The online survey is a method that will gather a more substantial amount of data from a more significant number of participants in a short period of time (Chapman \& McNeill, 2005). The author will send the survey throughout different social media platforms such as Facebook, Instagram, YouTube, student emails from both Napier, ISM Munich, and students from previous study, and LinkedIn. After gathering a number answered from the survey, the researcher will analyze and interpret the surveys and provide answers to the research questions.

\subsubsection{Survey creation and distribution}




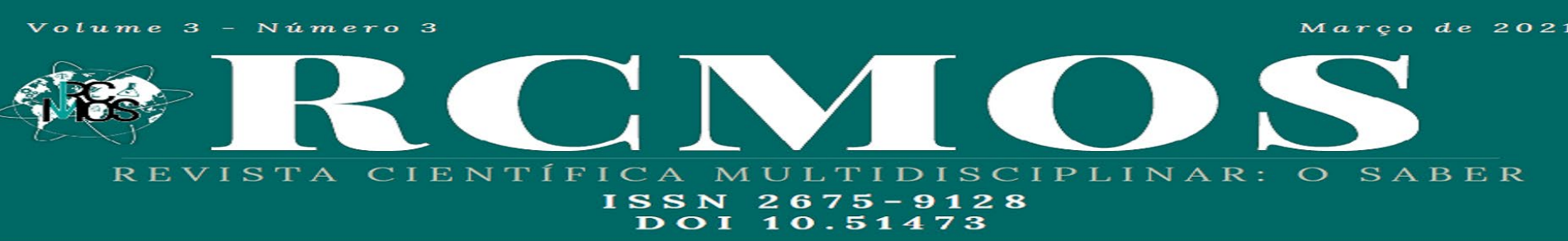

The online survey was developed and created through the "Umfrageonline" platform. It was distributed via the author's personal Instagram account and to different students of universities both in Germany and Brazil. The goal is to gather approximately 100 responses from German millennials and 100 responses from Brazilian millennials in order to get enough data.

The survey is written in the English language but with the possibility to translate to German and Portuguese. It consists of 34 mandatory questions ranging from single-select multiple- choice, multi-select multiple choice, rank order scaling, and rating scale questions. In addition, a few demographic questions concerning nationality, gender, and age were included. Furthermore, questions concerning influencer marking in social media and attitudes toward choosing a destination based on influencer marketing were added to the questionnaire. Moreover, questions about recent travel destinations followed the demographic questions. Questions containing screenshots from travel-related influencer posts on social media were also asked.

\subsubsection{Survey questions description}

The survey is divided into four main "chapters", including personal details, social media and influencers in general, destination choice in general and travel influencers and inspirations. The first chapter, personal detail questions, enquire about gender, nationality, age and employment status. As the survey is investigating about German and Brazilian millennials choosing a destination, the personal detail questions are fundamental because they help the researcher exclude the participants that are not either German or Brazilian, that are age less than 18 and above 34 years old.

The second chapter regards social media and influencers in general, with questions aimed to uncover participants' social media usage. Some of the questions asked in this section were: "Which social media channels do you use?", "Why do you use social media?" and "Which format of social media is most appealing to you?". This chapter helps to demonstrate millennia's interaction with social media. The third chapter is the destination choice general. The questions ask about preferences of long or short trips, which attractions and qualities influence travel destination choice, which factors cause participants to not choose a destination. It helps to identify the destination preference of German and Brazilian millennials.

The fourth chapter is on travel influencers and inspirations. Here, questions were developed based on influencer images. The researcher chose four different influencers, two of 
Moreover, all the participants have been equally respected. Participants were asked their full consent for information to be used. The survey participants have the right to refused to answer any question that they do not wish to answer or cancel the questionnaire at any time. The research was compiled in accordance with European data protection regulations. In addition, the questions avoided the potential to make participants uncomfortable by fore- going sensitive topics and difficult questions (McKeown \& Weed, 2004).

\subsubsection{Validity}

The validity is concerned with the issue of the conclusions developed throughout the research and involves four main consideration categories (Lincoln \& Guba, 1985). In order to increase the validity of the research study is essential to consider:

3.7.1.1 Credibility- Firstly, in order to ensure the credibility of the research, highlyregarded and peer-reviewed articles from a variety of sources were engaged with. highlight and applied.

3.7.1.2 Transferability - This concept relates to whether findings can be applied to different contexts. The transferability of this research study will apply to relevant and similar topic areas. In order to ensure transferability, the literature review has explained and described the main foundation of the research topic. In addition, it has explained the different underlying assumptions of each study field.

3.7.1.3 Dependability - Thirdly, dependability relates to whether the findings can be applied at other times.

3.7.1.4 Confirmability- This refers to the ability of this research study to be replicated at a later point in time with similar results. As individuals have different experiences in their life time, it is more likely that even if the research was done with the same participants the answers might be different. This is due to the fact that their circumstances (Personal, macroeconomic, institutional and political) might change, making them more or less susceptible to influencer marketing related to tourism. For example, the millennials that would travel less now due to money reasons might travel more later because his or her financial situation has improved. 


\section{ISSN $2675-9128$}

quantitative research methodology, including the research strategy, research design, and focus on the target group, was analyzed and explained. The methodology also explained how research questions were formulated to conduct the research study. To be able to achieve the desired level of insight, German and Brazilians millennials were chosen as a target sample, as these consumer groups are highly involved and interactive on social media, influencer marketing, and destination choice. The chapter discussed the limitations of this study. Moreover, ethical considerations were discussed, including ethical deliberations pertaining to the process of obtaining consent to collect and process survey data. In the next chapter, the findings and discussions of the data collected from the study will be presented. 


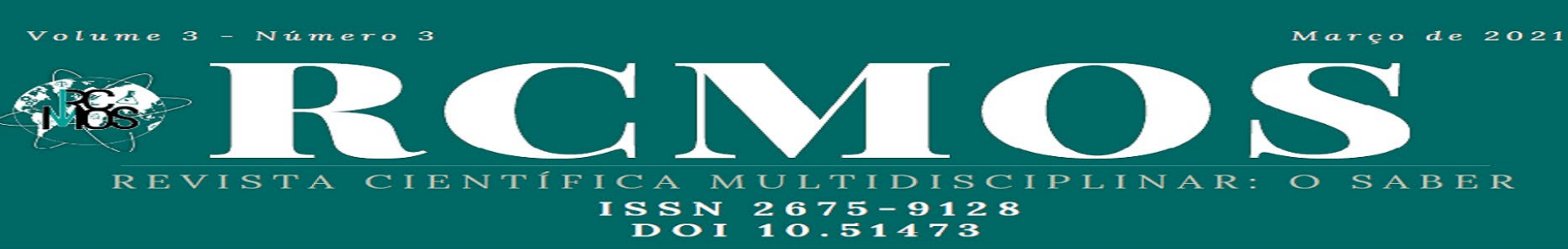

\section{Chapter 4: Data Description}

This chapter will explain and present the structure and main results of the primary data collected through an online questionnaire. In addition, the main results of the data collection will be described and explained in detail. However, no analysis or discussion will be con- ducted in this chapter. The online survey responses will be presented, illustrated, and the main points will be highlighted. In addition, information will be visually represented in the form of diagrams and tables.

The primary data was collected in June 2020 via an online questionnaire. The online questionnaire had a timeframe of about two weeks during which participants could answer. Considering the time difference of five hours between Brazil and Germany, the author believed that two weeks would be a good time to connect with all the participants. The author's main strategy was to send private message throughout different social media platforms such as Instagram, WhatsApp, and emails. It is important to have this direct communication with an individual because they are more likely to answer the survey compared to if the author would make a long group. In addition, friends and family helped to forward the online survey to other acquaintances. The online survey tool www.umfragenonline.com was used for the online questionnaire. The author had an app application where they would keep tracking answers in real-time. This enables the author to track the number of answers and remind the participants to answer.

The results of the primary data collection through the online survey were exported to Microsoft Excel. To have comparable, valuable, and consistent information sourcing from the primary data, the author made certain changes to the Excel data. The key changes were only keeping the completely answered questions, which were exported to Microsoft Excel. In addition, all the answers from participants younger than 18 and older than 35 were not transferred and weren't analyzed for the purpose of this thesis. In addition, the author had to adapt certain changes such as coding the answers to transfer them to the IBM SPSSS statistics 26 software. The IBM SPSS Statistics is a software platform that helps to analyze and better understand complex data and give high accuracy results in the marketing study field (IBM, 2020). 


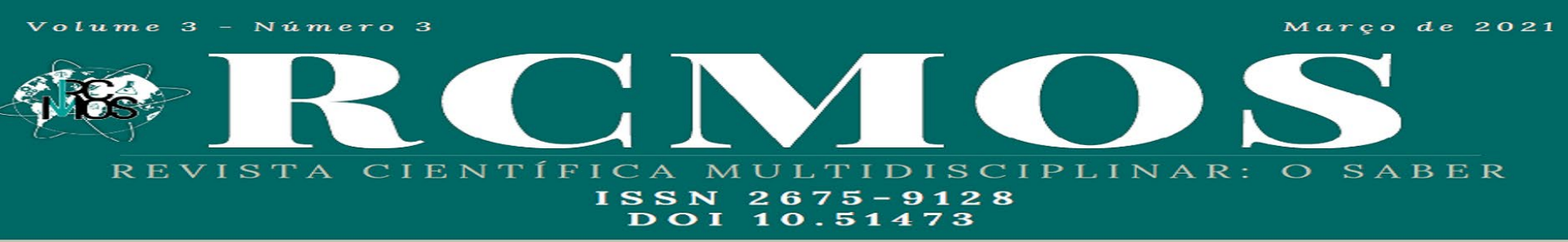

is about the impact of influencer marketing between Brazilian and German millennials, it is important to address the participant's different receptibility to influencers and pictures. It is important to identify whether images have a great impact on the Brazilian and German millennials when choosing a destination. Therefore, at the end of the fourth section, pictures of four influencer publications in different destinations were shown. There were two leading influencers from Brazil and two leading influencers from Germany. This was made on purpose in order to acknowledge whether each nationality the followers would recognize their influencers and if it would impact the travel decision making a choice.

\subsection{Results of an online questionnaire}

The questionnaire was open for participants from the beginning of June for two weeks of time frame. About 231 participants responded, and 196 of those completed the survey. However, 35 participants did not finish answering the questionnaire. Total 85 were Brazilian, and 57 were German, and 54 were others.

\subsubsection{Personal details}

Figure 3 shows that $34 \%$ of the Brazilian females and $26 \%$ of the Brazilian males answer the online survey. About $23 \%$ of the German females and $17 \%$ German males responded to the online survey.

Figure 3: Gender by Nationality

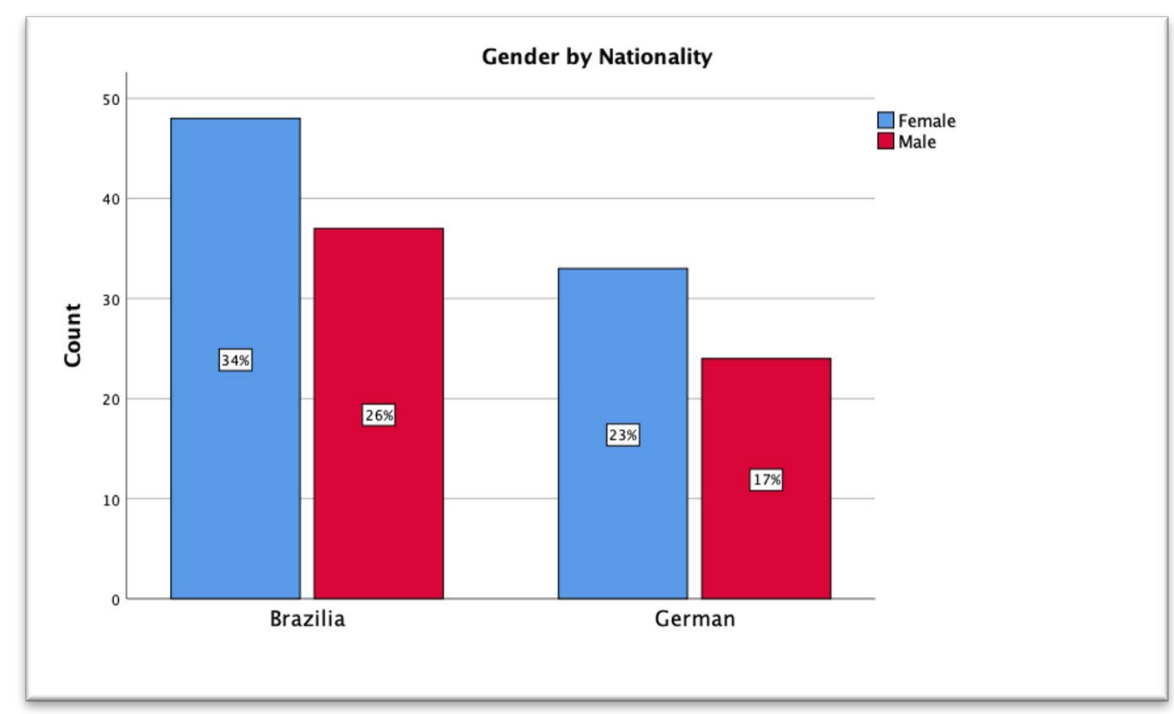

Source: Own illustration 
Moreover, to get more knowledge about the age group, open questions were made. Those aged between 18 to 35 was selected in order to have a representative sample. After the questions were answered, the author chose to only analyze the age group defined as millennials. As shown in figure $4,93 \%$ of participants were between 25 and 35 years old. $5 \%$ of respondents were under 18 years old, and 2\% were between 36 and 45 years old. It is important to acknowledge that the online questionnaire was distributed mainly on different social media platforms, and the survey was only complete online.

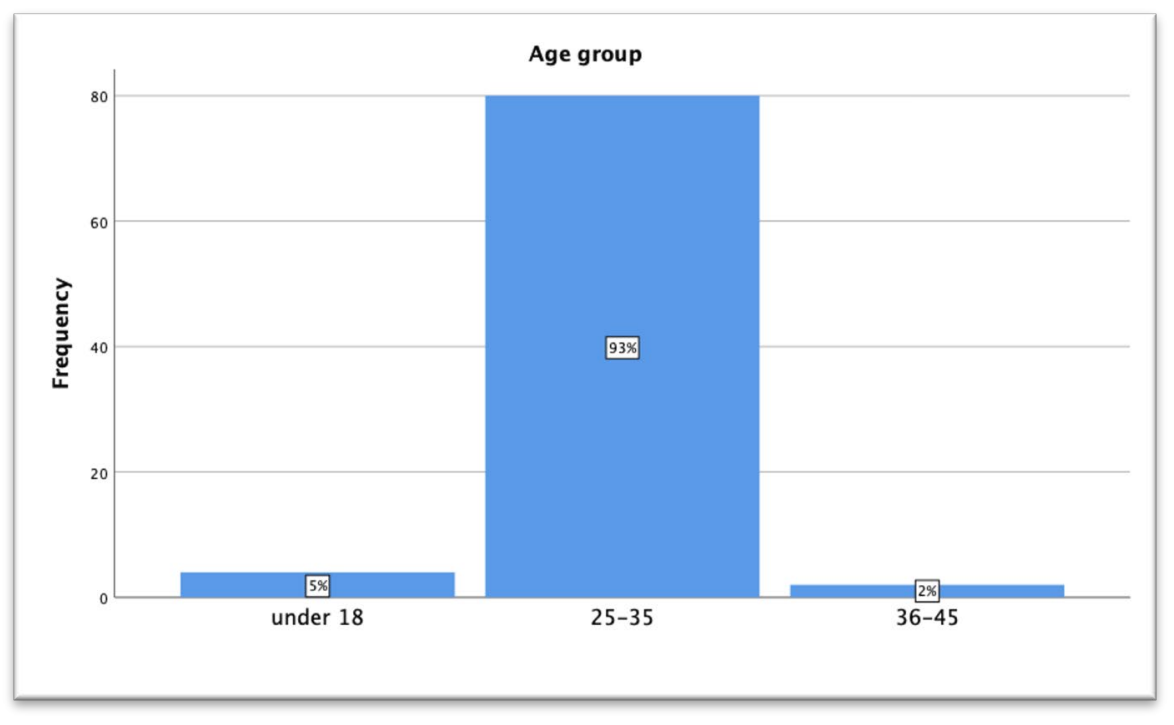

Figure 4: Age group

Source: Own illustration

Furthermore, participants were asked about their occupation, where they could choose between student, employee, self-employed, unemployed, or could choose not to answer. Figure 5 shows that $25 \%$ of Brazilian millennials had a higher number of employees, whereas among German millennials only $13 \%$ were employees. A higher proportion of German millennials (25\%) were still students. It is important information as it shows that Brazilian millennials are already working and are independent financially, which can have a different impact on their destination choice. In contrast, German millennials are still depending on their parents financially. In addition, Brazilian millennials have a higher unemployment rate with $6 \%$ compared to German millennials with $1 \%$. This is also important as it implies that both groups are likely to have different budgets when choosing a destination. It is important for Marketers to be aware of macroeconomic indexes like unemployment and minimum wage for each nationality. In addition, employment also affects the amount of time of holidays that can be 


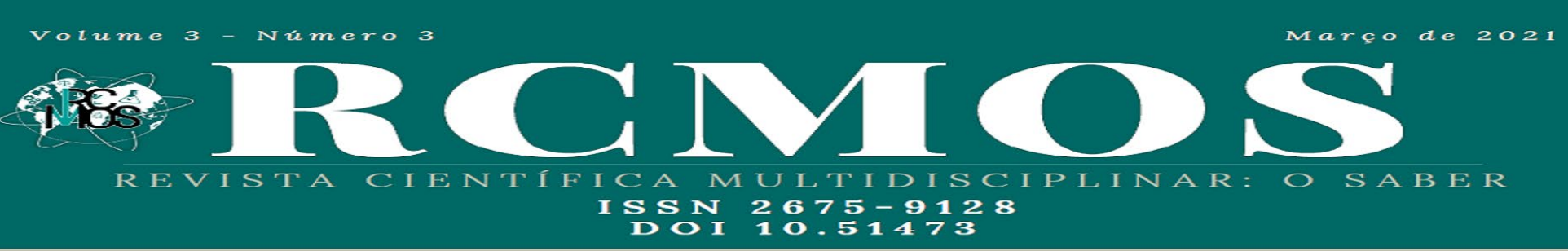

taken. Whereas students usually have more "free time" to travel and are more flexible with time and study, a person working full-time will is likely to be less flexible with holiday times and holiday duration. 
Figure 5: Current state of employment by Nationality

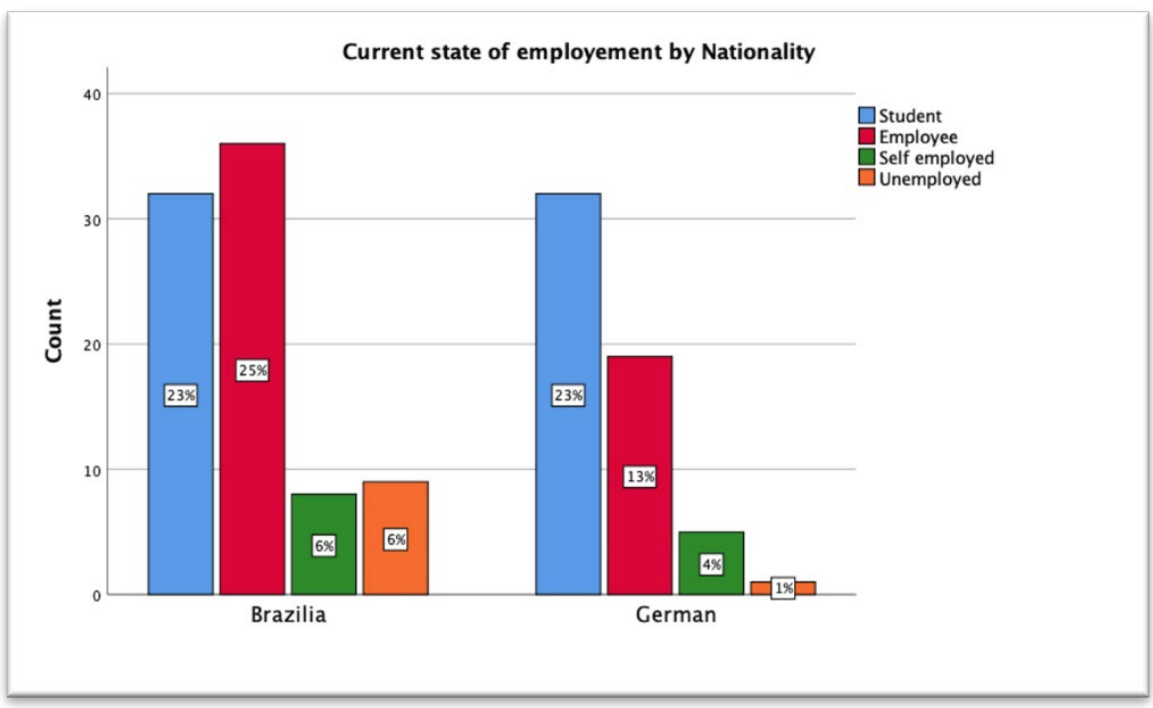

Source:

illustration

\subsubsection{Social media \& Influencers in general}

For the rest of this chapter, the graphs will be illustrated with the total number of participants who completed the online survey. In the data analysis chapter, the author will only analyze the information pertaining to Brazilian and German millennials. To better gain knowledge about which type of social media channel the participants use, a range of different social media channels was given as an option. The participants were given seven different social media platforms that are currently very trendy and have a high global user base. Figure 6 shows that, of all participants who answered the online questionnaire, about $92.3 \%$ use Instagram, 83.0\% use Facebook, and 80.4\% use YouTube.

Figure 6: Social media platforms

179 (92.3\%): Instagram

161 (83.0\%): Facebook

156 (80.4\%): Youtube

37 (19.1\%): Snapchat

35 (18.0\%): Tiktok

52 (26.8\%): Twitter

60 (30.9\%): Pintrest

1 (0.5\%): None

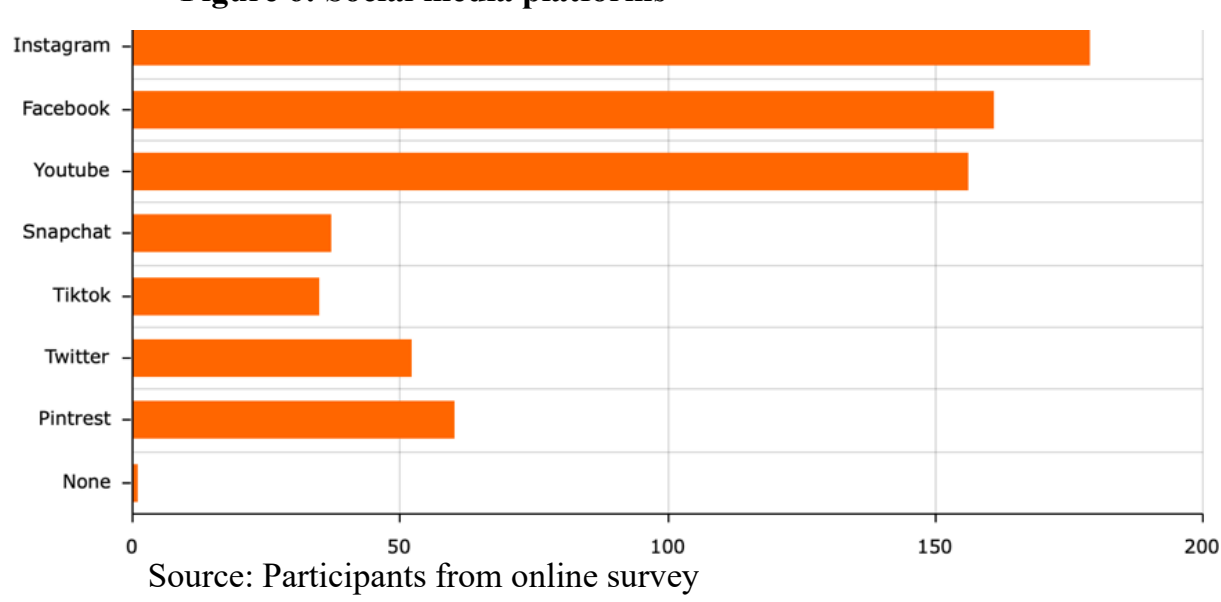


In addition, a question regarding which social media channel respondents spent the most time on generated the following results:

Instagram-63.40\%, Facebook-17.01\% YouTube- $13.40 \%$.

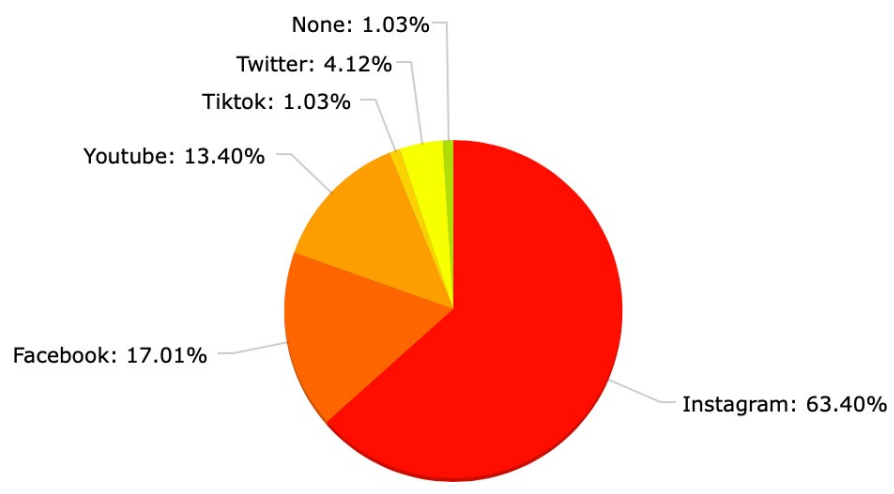

Figure 7: Time spending on social media

Source: Participants from online survey

\subsubsection{Pre-research destination choice}

To gain more knowledge about how the participants make their pre-research destination choice based on influencer marketing, the author created a general question to address what content the participants view on social media. This gives the author a better overview to understand if the participants usually see influencer contents on social media. For the purpose of this dissertation, it is important to discover which content attracts German and Brazilian millennials on social media in order to adapt the destination-related content to their preferences. Figure 8 shows that $78.9 \%$ see friends and family content, and about $55.2 \%$ see influencers content.

$153(78.9 \%)$ : Friends \& family

107 (55.2\%): Influencers

62 (32.0\%): Celebrities

50 (25.8\%): Micro influencers

57 (29.4\%): Strangers who's content you feel connected to

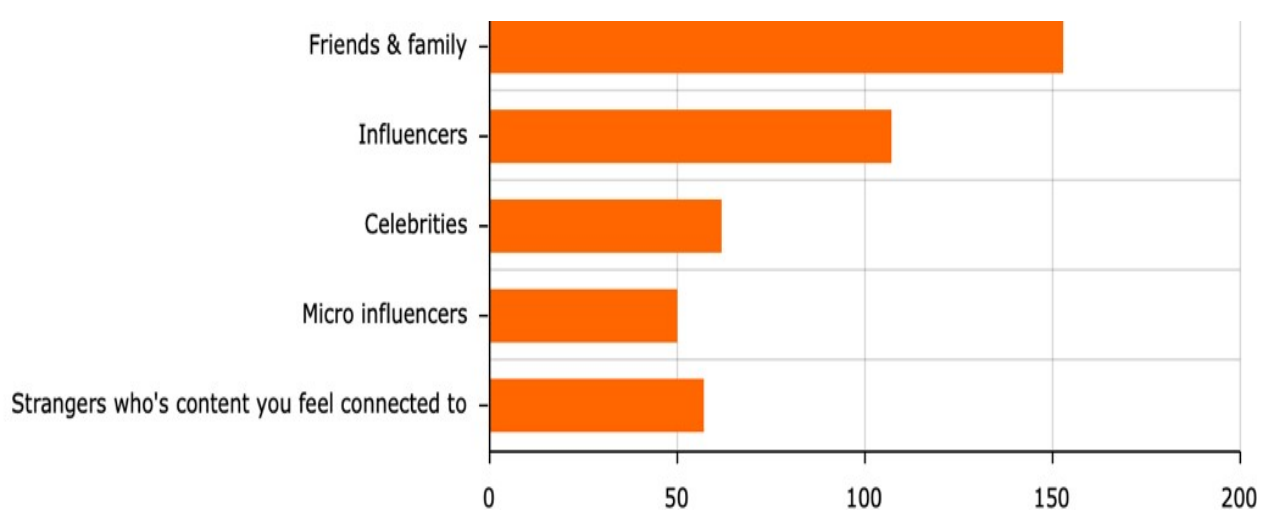

Figure 8: Social media content

Source:Participants from online survey 
Furthermore, it is important to identify the reasons why participants use social media in order for marketers and influencers to target tourism content more effectively on social media platforms. The author asked the participants on the online survey to rank the importance they attach to social media use from 1 (most important) to 9 (least important). Table 1 shows that three of the nine categories stand out, as they have a significantly higher value than average. The three main reasons to have social media are to keep in touch with friends, to pass the time / be entertained, and to get inspired. The least popular reasons were to promote products and to discuss topics.

Table 1: Reasons to use social media

\begin{tabular}{|c|c|c|c|c|c|c|c|c|c|c|c|c|c|c|c|c|c|c|c|c|}
\hline & \multicolumn{2}{|r|}{1.} & \multicolumn{2}{|r|}{2.} & \multicolumn{2}{|c|}{3.} & \multicolumn{2}{|r|}{4.} & \multicolumn{2}{|r|}{5.} & \multicolumn{2}{|r|}{6.} & \multicolumn{2}{|c|}{7.} & \multicolumn{2}{|c|}{8.} & \multicolumn{2}{|c|}{9.} & & \multirow[b]{2}{*}{ \pm} \\
\hline & $\Sigma$ & $\%$ & $\Sigma$ & $\%$ & $\Sigma$ & $\%$ & $\Sigma$ & $\%$ & $\Sigma$ & $\%$ & $\Sigma$ & $\%$ & $\Sigma$ & $\%$ & $\Sigma$ & $\%$ & $\Sigma$ & $\%$ & & \\
\hline To keep in touch with friends & $87 x$ & 42,23 & $42 x$ & 20,39 & $11 x$ & 5,34 & $10 x$ & 4,85 & $15 x$ & 7,28 & $5 x$ & 2,43 & $8 x$ & 3,88 & $11 x$ & 5,34 & $17 x$ & 8,25 & 3,14 & 2,72 \\
\hline To get opinions on products & $21 x$ & 10,19 & $24 x$ & 11,65 & $18 x$ & 8,74 & $20 x$ & 9,71 & $33 x$ & 16,02 & $31 x$ & 15,05 & $28 x$ & 13,59 & $23 x$ & 11,17 & $8 x$ & 3,88 & 4,88 & 2,34 \\
\hline To discuss topics & $9 \mathrm{x}$ & 4,37 & $19 \mathrm{x}$ & 9,22 & $25 \mathrm{x}$ & 12,14 & $21 x$ & 10,19 & $24 \mathrm{x}$ & 11,65 & $27 x$ & 13,11 & $25 \mathrm{x}$ & 12,14 & $33 x$ & 16,02 & $23 x$ & 11,17 & 5,50 & 2,39 \\
\hline To pass the time/ be entertained & $28 \mathrm{x}$ & 13,59 & $46 x$ & 22,33 & $38 \mathrm{x}$ & 18,45 & $25 x$ & 12,14 & $19 x$ & 9,22 & $21 x$ & 10,19 & $10 \mathrm{x}$ & 4,85 & $10 x$ & 4,85 & $9 x$ & 4,37 & 3,82 & 2,26 \\
\hline To stay informed about trends & $7 \mathrm{x}$ & 3,40 & $21 x$ & 10,19 & $30 x$ & 14,56 & $50 x$ & 24,27 & $35 x$ & 16,99 & $29 x$ & 14,08 & $22 x$ & 10,68 & $10 x$ & 4,85 & $2 x$ & 0,97 & 4,56 & 1,81 \\
\hline To promote products & $14 \mathrm{x}$ & 6,80 & $7 x$ & 3,40 & $8 x$ & 3,88 & $5 x$ & 2,43 & $18 \mathrm{x}$ & 8,74 & $19 x$ & 9,22 & $21 \mathrm{x}$ & 10,19 & $33 x$ & 16,02 & $81 x$ & 39,32 & 6,87 & 2,52 \\
\hline To help to make purchasing deci... & $2 x$ & 0,97 & $3 x$ & 1,46 & $8 x$ & 3,88 & $17 x$ & 8,25 & $18 \mathrm{x}$ & 8,74 & $43 x$ & 20,87 & $51 x$ & 24,76 & $37 x$ & 17,96 & $27 x$ & 13,11 & 6,52 & 1,77 \\
\hline To learn and discover & $15 x$ & 7,28 & $20 x$ & 9,71 & $30 x$ & 14,56 & $35 x$ & 16,99 & $23 x$ & 11,17 & $16 x$ & 7,77 & $31 \mathrm{x}$ & 15,05 & $22 x$ & 10,68 & $14 \mathrm{x}$ & 6,80 & 4,93 & 2,35 \\
\hline get inspired (eg. foo & $23 x$ & 11,17 & $24 x$ & 11,65 & $38 x$ & 18,45 & $23 x$ & 11,17 & $21 x$ & 10,19 & $15 x$ & 7,28 & $10 x$ & 4,85 & $27 x$ & 13,11 & $25 x$ & 12,14 & 4,77 & 2,66 \\
\hline
\end{tabular}

As part of the critical assessment of social media's importance, this is crucial for marketers and influencers to create a better strategy to post about products and services on social media. The participants were asked how often they use social media. $91.24 \%$ of the participants use social media several times a day, and $6.70 \%$ use once a day.

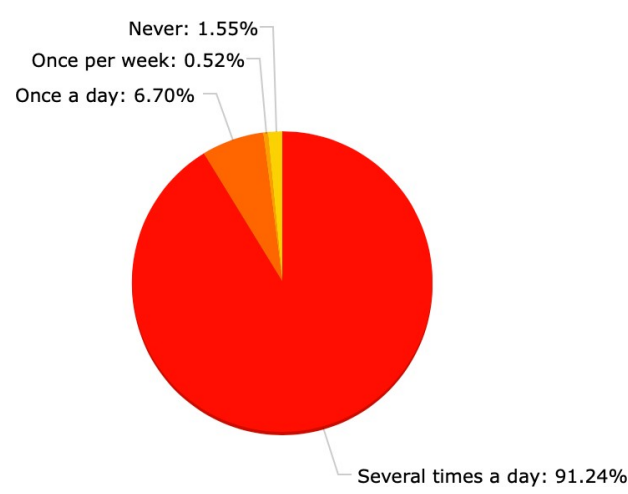

Figure 9: Usage of social media

Source: Participants from online survey 
Moreover, to further investigate the type of social media format that is most appealing, participants were asked about their preferred content format on social media. The majority of the participants $(79 \%)$ indicated that images were more appealing, while $66.5 \%$ preferred videos and $40.7 \%$ opted for the story function.

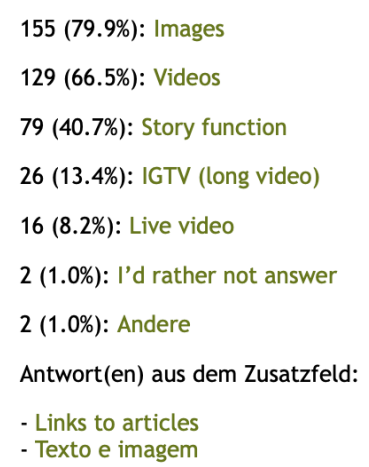

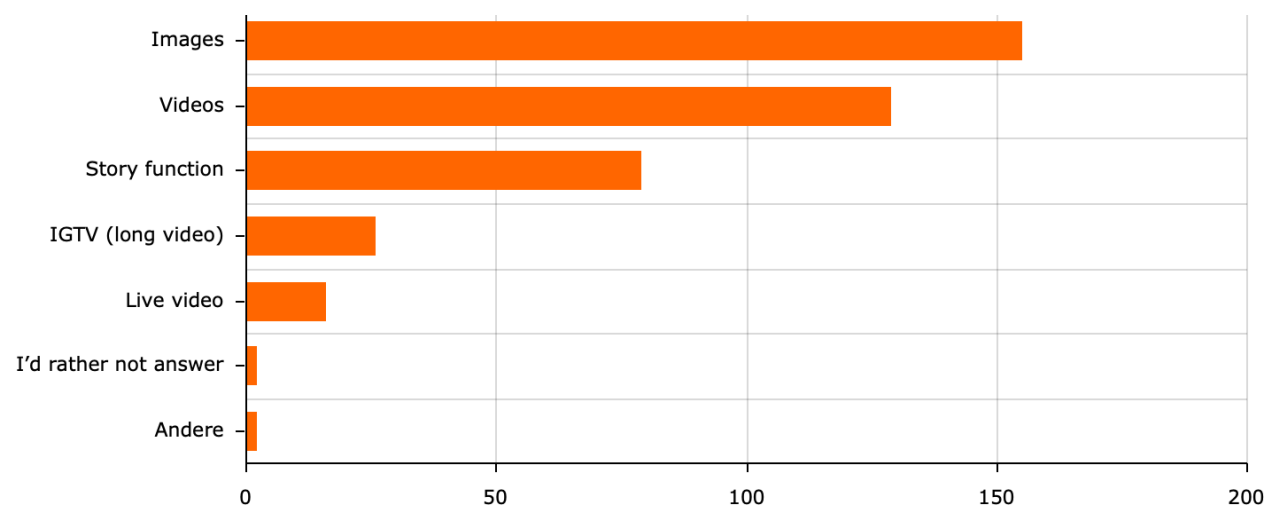

Figure 10: Social media format

\subsubsection{Social media interaction}

To further investigate how participants are interacting on social media, the author created two main questions. The first question is "What is your role/ participation on social media?" Figure 11 shows that $58.2 \%$ of the participants are "engaged but rarely post." About $28.4 \%$ are "active and post regularly."

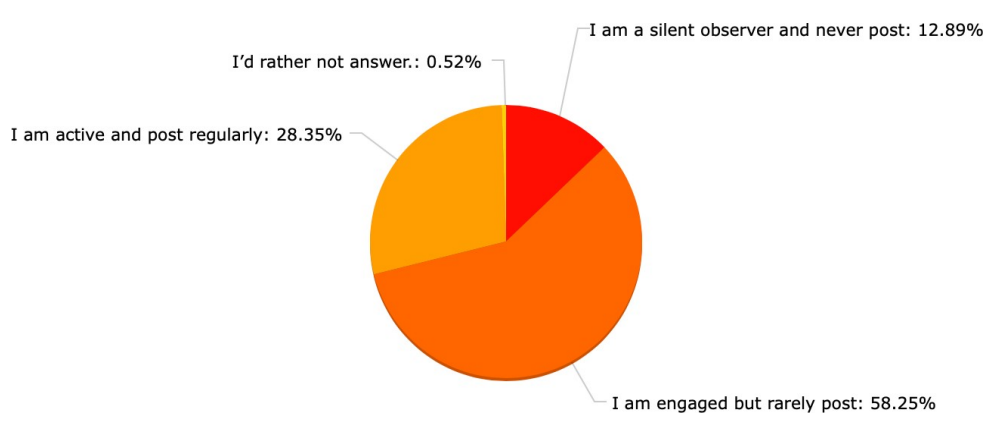

Figure 11: Role/participants in social media

Source: Participants from online survey

The second question intended to find out whether the participants post pictures on their social media regularly. Figure 12 shows that $61.34 \%$ of participants post travel pictures on their social media "sometimes." About 29.38\% post "always." 
Figure 12: Post-travel pictures on social media

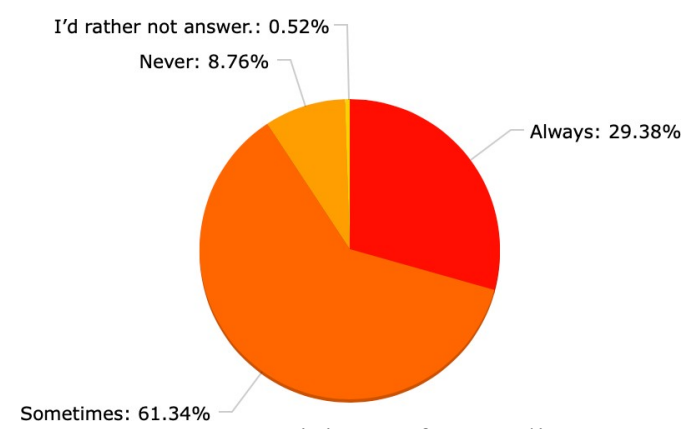

Source: Participants from online survey

\subsubsection{Influencer's content}

To investigate the degree of interest participants had in travel influencer content, two main questions were addressed. The first question asked participants which type of influencer content they were most interest in. Table 2 shows that entertainment content was most popular $(29.90 \%)$ with Sport \& healthy and Travel \& tourism both tying in second place at $21.13 \%$.

Table 2: Influencer marketing types

\begin{tabular}{|c|c|c|c|c|c|c|c|c|c|c|c|c|}
\hline & \multicolumn{2}{|c|}{1.} & \multicolumn{2}{|c|}{2.} & \multicolumn{2}{|c|}{3.} & \multicolumn{2}{|c|}{4.} & \multicolumn{2}{|c|}{5.} & \multirow[b]{2}{*}{$\varnothing$} & \multirow[b]{2}{*}{ \pm} \\
\hline & $\Sigma$ & $\%$ & $\Sigma$ & $\%$ & $\Sigma$ & $\%$ & $\Sigma$ & $\%$ & $\Sigma$ & $\%$ & & \\
\hline Beauty & $30 x$ & 15,46 & $38 x$ & 19,59 & $36 x$ & 18,56 & $49 x$ & 25,26 & $41 x$ & 21,13 & 3,17 & 1,38 \\
\hline Entertainment & $58 x$ & 29,90 & $53 x$ & 27,32 & $43 x$ & 22,16 & $20 x$ & 10,31 & $20 x$ & 10,31 & 2,44 & 1,30 \\
\hline Fashion & $24 x$ & 12,37 & $30 x$ & 15,46 & $27 x$ & 13,92 & $59 x$ & 30,41 & $54 x$ & 27,84 & 3,46 & 1,37 \\
\hline Sport \& Health & $41 x$ & 21,13 & $31 x$ & 15,98 & $43 x$ & 22,16 & $40 x$ & 20,62 & $39 x$ & 20,10 & 3,03 & 1,42 \\
\hline Travel \& Tourism & $41 x$ & 21,13 & $42 x$ & 21,65 & $45 x$ & 23,20 & $26 x$ & 13,40 & $40 x$ & 20,62 & 2,91 & 1,42 \\
\hline
\end{tabular}

The second question was about how many travel influencers the participants are following. Figure 13 shows that $80.20 \%$ at least follow between $10-50$ travel influencers. $12.89 \%$ of the participants answered, "I'd rather not answer, and 5.15 follow less than 100 travel influencers. 
Figure 13: Number of travel influencer follow

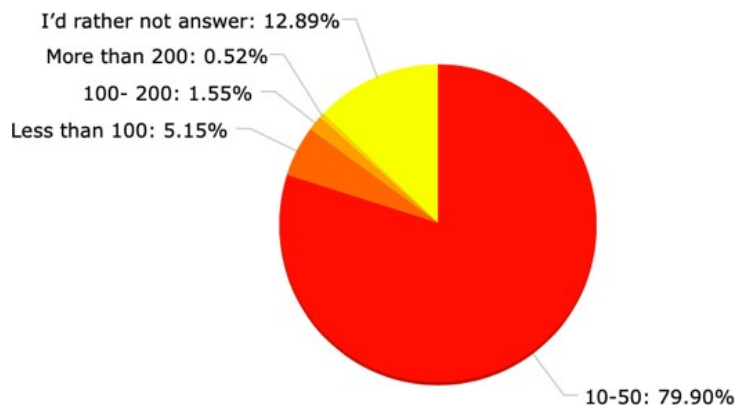

Source: Participants from online survey

The third question was about how regular the participants view travel influencers in their social media. Figure 14 shows that $52.06 \%$ of the participants do so "sometimes." About $12.89 \%$ "never" view a travel influencer. In addition, an equal number of respondents view travel influencers "once a day" and "once in a week," (11.34\%).

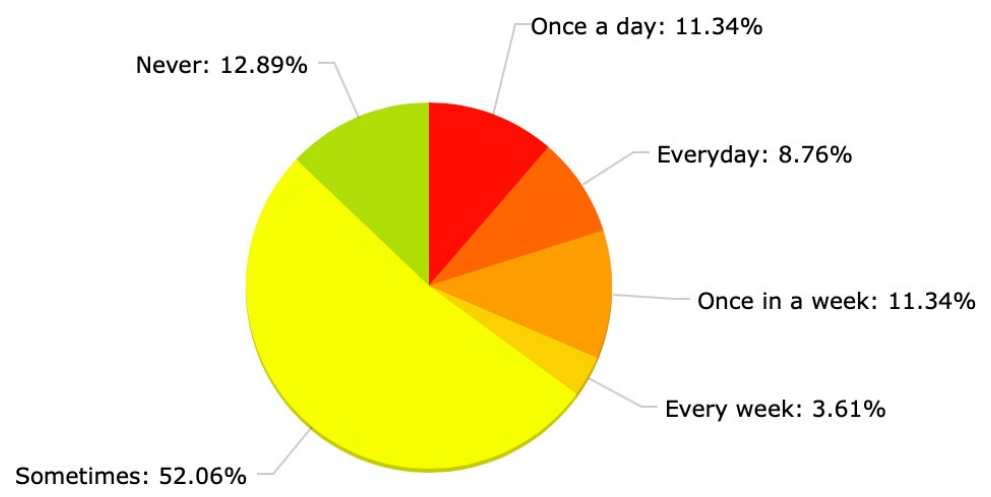

Figure 14: Regularly view travel influencers

Source: Participants from online survey

\section{Destination choice in general}

In the destination choice in general, questions were phrased to make the influencer choose where they would search for tourism-related information first if they had to plan a holiday right now. Figure 15 shows that family and friends dominated as information sources with $69.6 \%$, with social media following with $63.9 \%$. The options coming in third and fourth place had very close numbers: $36.6 \%$ chose blogs and $36.1 \%$ chose a travel agency. 


\section{ISSN $2675-9128$}

Figure 15: Social media format types

$13(6.7 \%):$ Advertising brochures
$71(36.6 \%):$ Blogs
$135(69.6 \%)$ Family, Friends
recommendations
$18(9.3 \%):$ Magazine/Newspaper
$70(36.1 \%)$ : Online Agency
$124(63.9 \%)$ : Social media
$12(6.2 \%):$ Television
$14(7.2 \%):$ Tevelivision/Movies/ Series
$70(36.1 \%):$ Travel Agency
5 (2.6\%): Andere
Antwort(en) aus dem Zusatzfeld:
- Web research on destination
- Google
- Google
- Experience
- Google

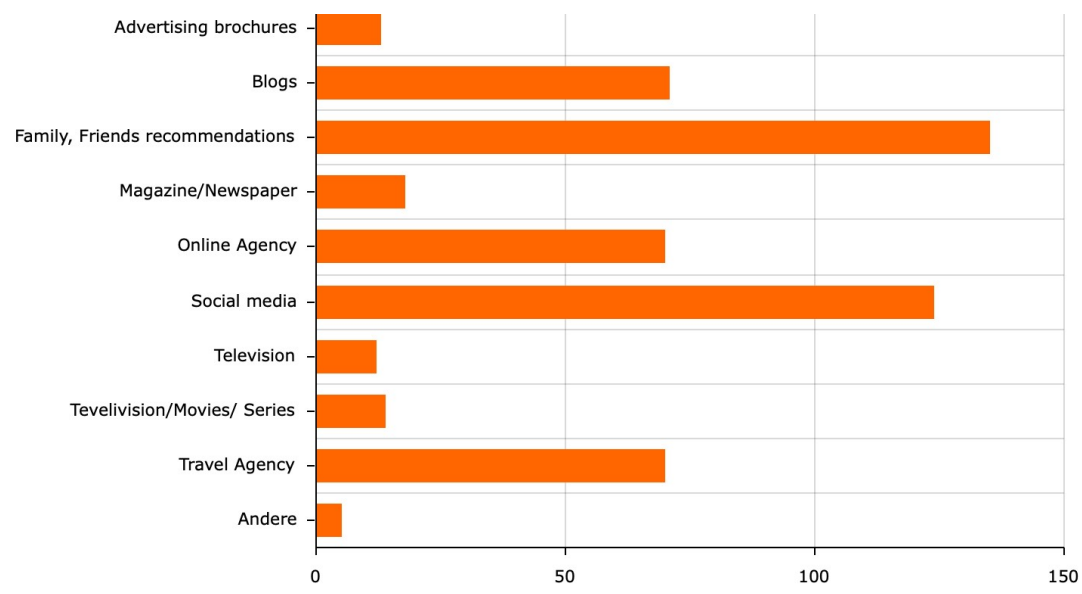

Source: Participants from online survey

Moreover, it is essential to acknowledge the factors that would motivate an individual not to choose a destination. The author addressed seven barriers that could be a negative factor to not travel to a certain destination. Figure 16 shows security as being the dominant impeding factor $(67.5 \%)$, followed by negative reviews (64.9\%) and lack of infrastructure (45.9\%). In addition, price/ exchange rate was also a relevant factor, with $42.3 \%$.

Figure 16: Barriers to "Not" choose a destination

79 (40.7\%): Bad weather
126 (64.9\%): Bad/negative reviews
89 (45.9\%): Lack of Infrastructure
26 (13.4\%): Language barrier
82 (42.3\%): Price / Exchange rate
131 (67.5\%): Security
41 (21.1\%): Visa requirement
2 (1.0\%): Andere
Antwort(en) aus dem Zusatzfeld:
- Other tourists, political situation
- Insects

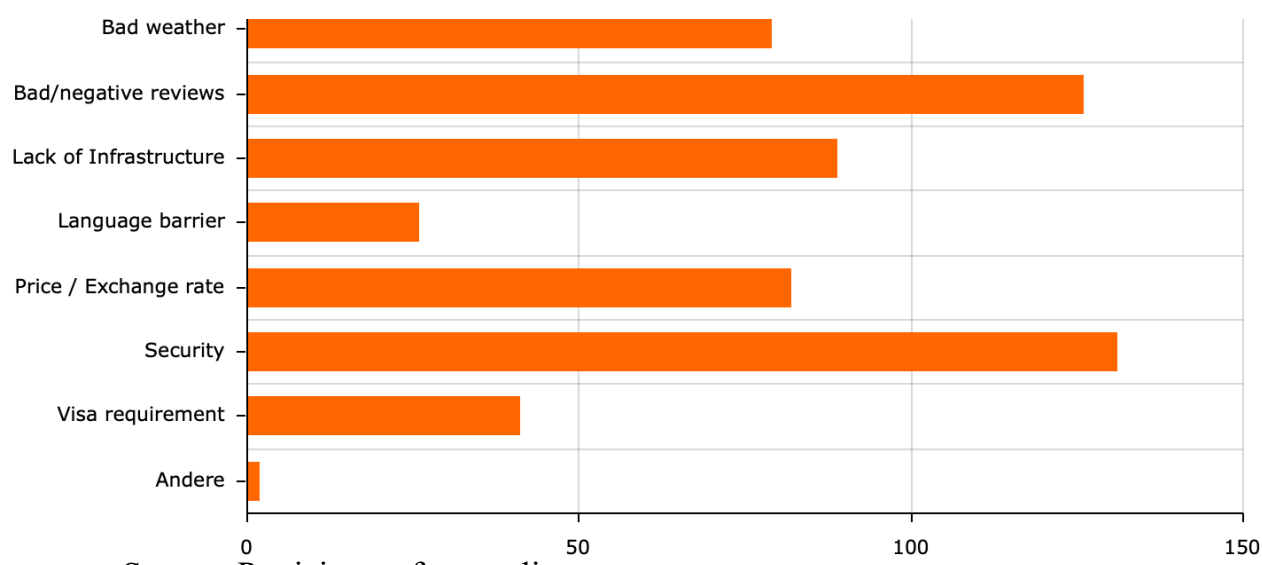

\subsubsection{Travel influencers and Inspirations}

Pictures from destinations can evoke various emotions in consumers. The author has given four different destination pictures with a social media influencer on It. The participants had the possibility to address whether they recognize the influencer from social media. Then, they were asked whether the image inspire them to travel to the depicted destination. Thirdly, they were asked whether they agree with different statements based on the picture. The first 
picture is from a German influencer who is well known for her travel and lifestyle pictures. Pilotmadeliene has about 1.1 million followers and is very interactive on her social media profile. She posted at least three times a day.

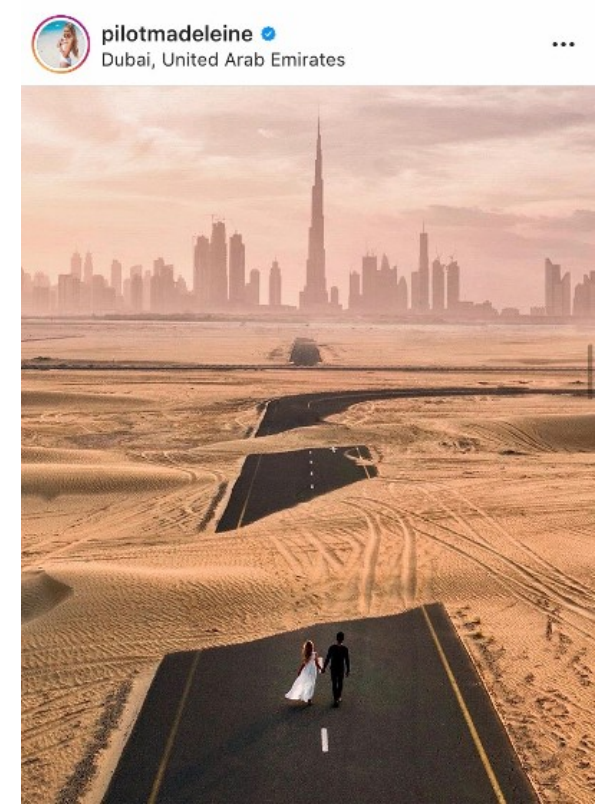

Source: Pilotmadeleine Instagram page

After looking at the picture, participants were asked if they recognized her from social media. About $85.05 \%$ said they did not, while 11,86\% said "YES," and 3.09\% were "Unsure."

Figure 17: Participants recognize the influencer

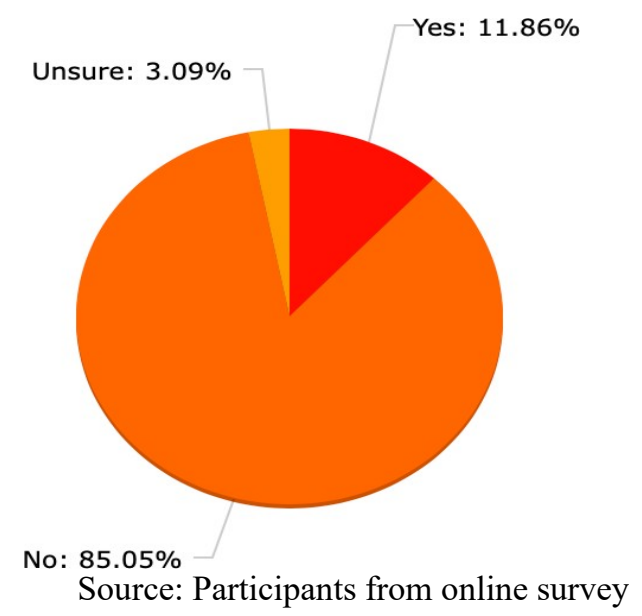

As the image was from Dubai, the participants were asked whether it inspired them to go to Dubai. About 69.59\% said "NO, "and 30.41\% said "YES". 


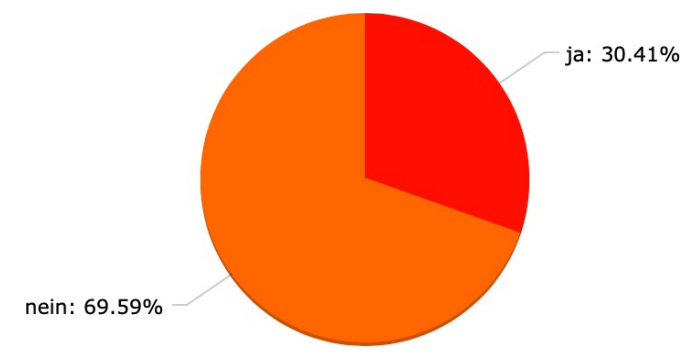

Figure 18: Participants wanted to travel to Dubai Source: Participants from online survey

Participants were subsequently given four main statements, which they had to respond to with answers ranging from strongly agree to strongly disagree. Table 3 illustrates the four main statements.

Table 3: Travel characteristic

\begin{tabular}{|c|c|c|c|c|c|c|c|c|c|c|c|c|}
\hline & \multicolumn{2}{|c|}{$\begin{array}{c}\text { Strongly agree } \\
\text { (1) }\end{array}$} & \multicolumn{2}{|c|}{$\begin{array}{l}\text { Agree } \\
(2)\end{array}$} & \multicolumn{2}{|c|}{$\begin{array}{c}\text { Neither agree, } \\
\text { Nor disagree } \\
\text { (3) }\end{array}$} & \multicolumn{2}{|c|}{$\begin{array}{l}\text { Disagree } \\
\text { (4) }\end{array}$} & \multicolumn{2}{|c|}{$\begin{array}{c}\text { Strongly disagree } \\
\text { (5) }\end{array}$} & \multirow[b]{2}{*}{$\varnothing$} & \multirow[b]{2}{*}{ \pm} \\
\hline & $\Sigma$ & $\%$ & $\Sigma$ & $\%$ & $\Sigma$ & $\%$ & $\Sigma$ & $\%$ & $\Sigma$ & $\%$ & & \\
\hline The presentation of the landscape... & $13 x$ & 6,70 & $39 x$ & 20,10 & $54 x$ & 27,84 & $73 x$ & 37,63 & $15 x$ & 7,73 & 3,20 & 1,06 \\
\hline The influencer inspired me & $8 x$ & 4,12 & $31 x$ & 15,98 & $44 x$ & 22,68 & $93 x$ & 47,94 & $18 x$ & 9,28 & 3,42 & 1,00 \\
\hline The picture is beautiful. I want to ... & $17 x$ & 8,76 & $49 x$ & 25,26 & $63 x$ & 32,47 & $51 x$ & 26,29 & $14 x$ & 7,22 & 2,98 & 1,08 \\
\hline Looking at this imagine I can reall... & $9 x$ & 4,64 & $53 x$ & 27,32 & $57 x$ & 29,38 & $59 x$ & 30,41 & $16 x$ & 8,25 & 3,10 & 1,04 \\
\hline
\end{tabular}

The second social media influencer was Brazilian. Like the German influencer, he is well known for his travel pictures. He has 78.7 thousand followers and regularly post on his Instagram account.

Figure 19: Travel characteristic

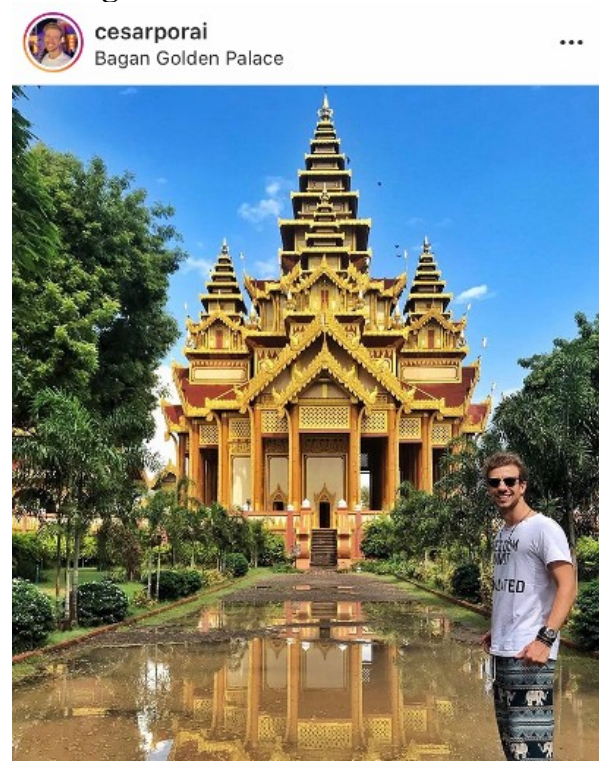


The participants were asked if they recognized him from social media. About 89.18\% answered with "NO," 8.25\% said "YES," and 2.58\% were "Unsure."

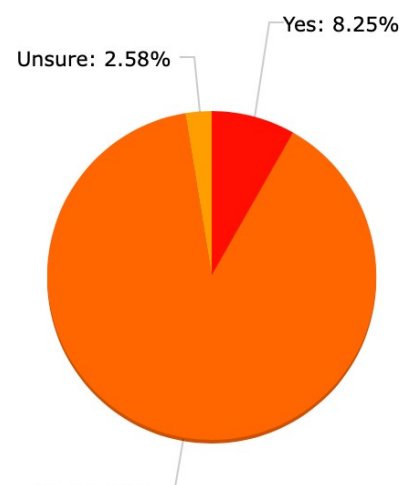

No: $89.18 \%$

Figure 19: Participants recognize the influencer

Source: Participants from online survey

After looked at the picture, the participants were asked whether the image inspired them to go to Golden Palace. About 59.28\% said "NO," and 40.72\% said "YES".

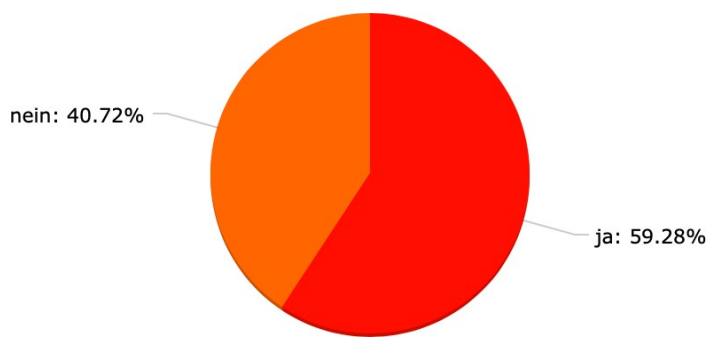

Figure 20: Participants wanted to go to Golden Palace Source: Participants from online survey

Participants were subsequently given four main statements, for which they could select responses ranging from strongly agree to disagree strongly. Table 3 shows the four main statements.

Table 4: Travel characteristic

\begin{tabular}{|c|c|c|c|c|c|c|c|c|c|c|c|c|}
\hline & \multicolumn{2}{|c|}{$\begin{array}{c}\text { Strongly agree } \\
\text { (1) }\end{array}$} & \multicolumn{2}{|c|}{$\begin{array}{l}\text { Agree } \\
\text { (2) }\end{array}$} & \multicolumn{2}{|c|}{$\begin{array}{c}\text { Neither agree, } \\
\text { Nor disagree } \\
\text { (3) }\end{array}$} & \multicolumn{2}{|c|}{$\begin{array}{c}\text { Disaagree } \\
\text { (4) }\end{array}$} & \multicolumn{2}{|c|}{$\begin{array}{c}\text { Strongly disagree } \\
\text { (5) }\end{array}$} & \multirow[b]{2}{*}{$\emptyset$} & \multirow[b]{2}{*}{ \pm} \\
\hline & $\Sigma$ & $\%$ & $\Sigma$ & $\%$ & $\Sigma$ & $\%$ & $\Sigma$ & $\%$ & $\Sigma$ & $\%$ & & \\
\hline The presentation of the landscape... & $20 x$ & 10,31 & $77 x$ & 39,69 & $62 x$ & 31,96 & $24 x$ & 12,37 & $11 x$ & 5,67 & 2,63 & 1,02 \\
\hline The influencer inspired me & $12 x$ & 6,19 & $56 x$ & 28,87 & $64 x$ & 32,99 & $45 x$ & 23,20 & $17 x$ & 8,76 & 2,99 & 1,06 \\
\hline The picture is beautiful. I want to ... & $20 x$ & 10,31 & $79 x$ & 40,72 & $53 x$ & 27,32 & $32 x$ & 16,49 & $10 x$ & 5,15 & 2,65 & 1,04 \\
\hline Looking at Bagan Golden Palace I j... & $28 x$ & 14,43 & $88 x$ & 45,36 & $43 x$ & 22,16 & $26 x$ & 13,40 & $9 x$ & 4,64 & 2,48 & 1,04 \\
\hline
\end{tabular}


The third social media influencer is a German influencer. She is well known for travel pictures and has about 1.3 million followers. She regularly posts on her Instagram account and creates everyday live videos from the places she is traveling to.

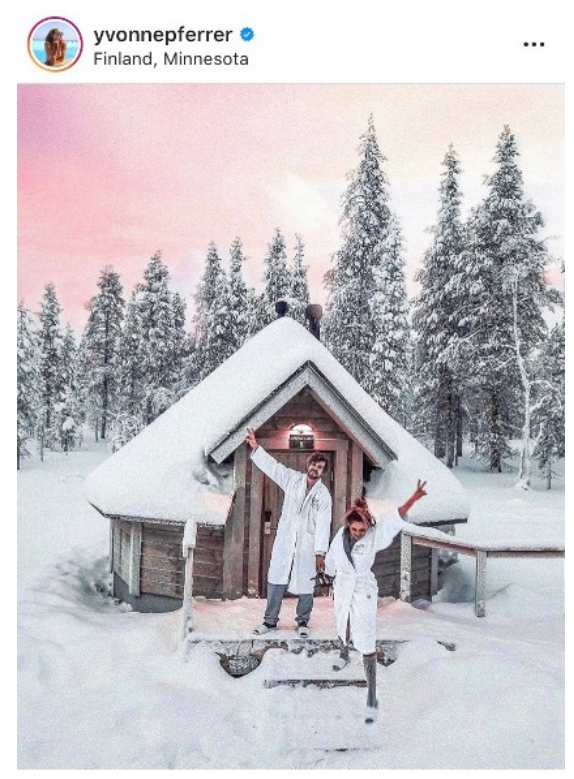

Source: Yvonnepfererer Instagram page

The participants were asked if they recognized her from social media. About $81.44 \%$ said "NO", 15,46\% said" YES" and 3.09\% were "Unsure".

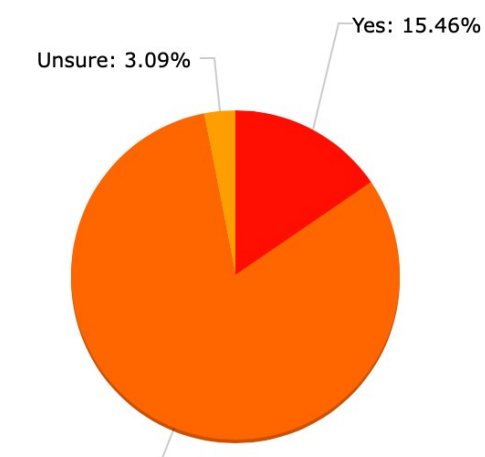

No: $81.44 \%$

Figure 21: Participants recognize the influencer

Source: Participants from online survey

The participants were asked whether the image inspired them to go to Finland. About 59.79\% said "NO," and 40.21\% said "YES." 

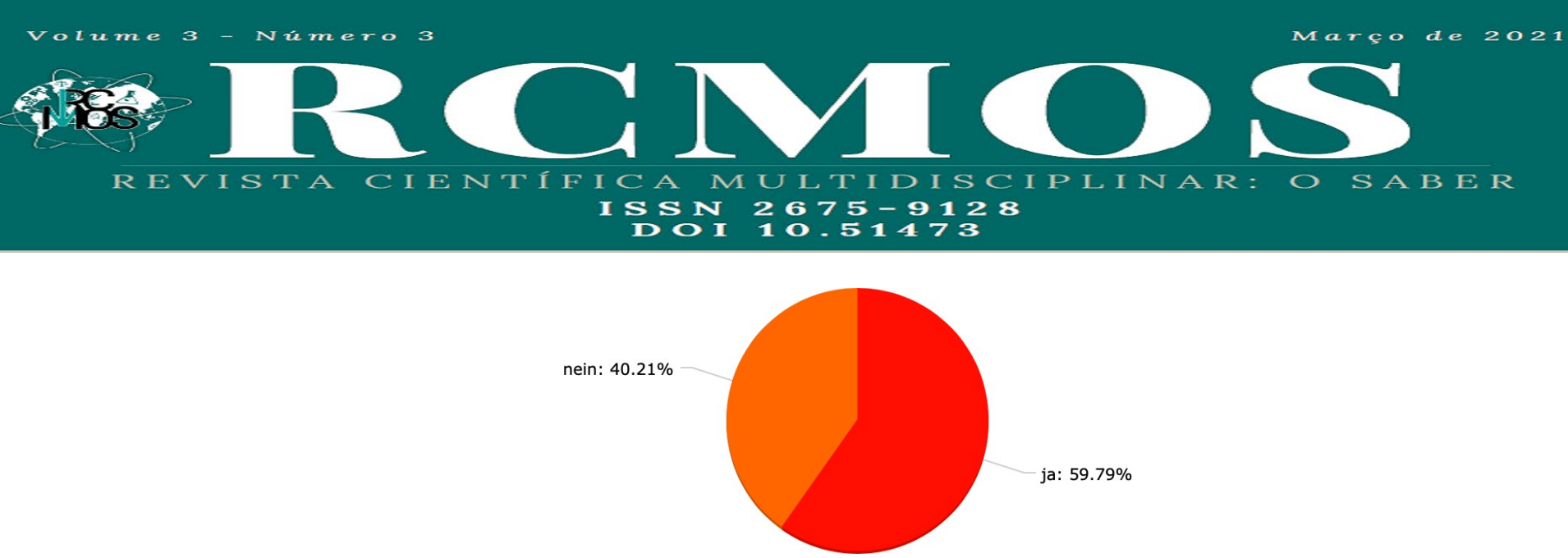

Figure 22: Participants wanted to go to Finland

Source: Participants from online survey

Finally, participants were given four main statements, to which they could respond to with statements ranging from strongly agree to strongly disagree. Table 5 illustrate the four main statements.

Table 5: Travel characteristic

\begin{tabular}{|c|c|c|c|c|c|c|c|c|c|c|}
\hline & \multicolumn{2}{|c|}{ Strongly agree } & \multicolumn{2}{|c|}{ Agree } & \multicolumn{2}{|c|}{$\begin{array}{c}\text { Neither agree } \\
\text { Nor disagree }\end{array}$} & \multicolumn{2}{|c|}{ Disagree } & \multicolumn{2}{|c|}{ Strongly disagree } \\
\hline & $\Sigma$ & $\%$ & $\Sigma$ & $\%$ & $\Sigma$ & $\%$ & $\Sigma$ & $\%$ & $\Sigma$ & $\%$ \\
\hline The presentation of the landscape convinced me & $34 x$ & 17,53 & $78 x$ & 40,21 & $48 x$ & 24,74 & $34 x$ & 17,53 & $1 x$ & 0,52 \\
\hline The influencer inspired me & $29 x$ & 14,95 & $54 x$ & 27,84 & $54 x$ & 27,84 & $53 x$ & 27,32 & $6 x$ & 3,09 \\
\hline The picture is beautiful. I want to go to Finland! & $35 x$ & 18,04 & $83 x$ & 42,78 & $48 x$ & 24,74 & $27 x$ & 13,92 & $2 x$ & 1,03 \\
\hline The image gives me the feeling a of cozy morning winter. & $37 x$ & 19,07 & $85 x$ & 43,81 & $36 x$ & 18,56 & $34 \mathrm{x}$ & 17,53 & $4 \mathrm{x}$ & 2,06 \\
\hline
\end{tabular}

The fourth social media influencer is a Brazilian influencer. She is well known for her travel pictures and has about 260 thousand followers. She is very active in social media.

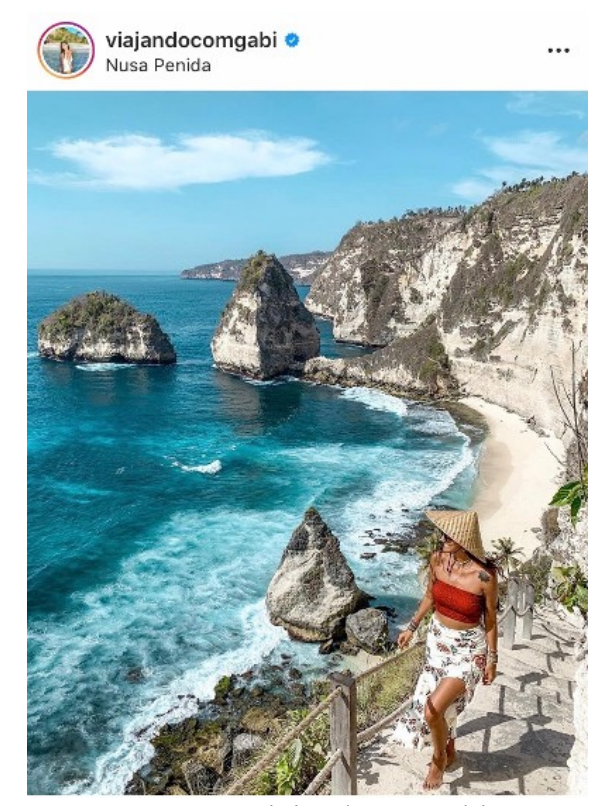

Source: Viajandocomgabi 
The participants were asked if they recognized her from social media. About $79.38 \%$ said "NO," 14.43 \% said "YES," and 6.19\% were "Unsure."

Figure 23: Participants recognize the influencer

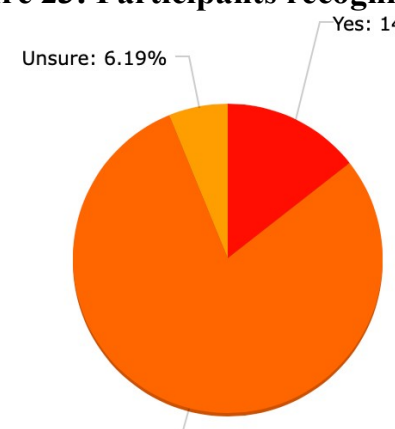

No: $79.38 \%$

Source: Participants from online survey

The participants were asked whether the image inspired them to go to Nusa Penida. About 79.90\% said "YES," and 20.10\% said "NO."

Figure 24: Participants wanted to go to Nusa Penida

nein: $20.10 \%$

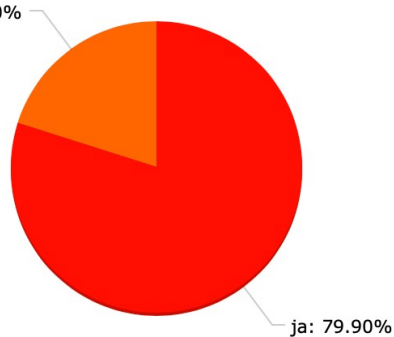

Source: Participants from online survey

After the participants were given four main statements to be ranked from strongly agree to strongly disagree. Table 5 illustrates the four main statements.

Table 6: Travel characteristic

\begin{tabular}{|c|c|c|c|c|c|c|c|c|c|c|c|c|}
\hline & \multicolumn{2}{|c|}{$\begin{array}{c}\text { Strongly agree } \\
\text { (1) }\end{array}$} & \multicolumn{2}{|c|}{$\begin{array}{l}\text { Agree } \\
\text { (2) }\end{array}$} & \multicolumn{2}{|c|}{$\begin{array}{c}\text { Neither agree, } \\
\text { Nor disagree } \\
\text { (3) }\end{array}$} & \multicolumn{2}{|c|}{$\begin{array}{c}\text { Disagree } \\
\text { (4) }\end{array}$} & \multicolumn{2}{|c|}{$\begin{array}{c}\text { Strongly disagree } \\
\text { (5) }\end{array}$} & \multirow[b]{2}{*}{$\varnothing$} & \multirow[b]{2}{*}{ \pm} \\
\hline & $\Sigma$ & $\%$ & $\Sigma$ & $\%$ & $\Sigma$ & $\%$ & $\Sigma$ & $\%$ & $\Sigma$ & $\%$ & & \\
\hline The presentation of the landscape... & $59 x$ & 30,41 & $95 x$ & 48,97 & $27 x$ & 13,92 & $10 x$ & 5,15 & $3 x$ & 1,55 & 1,98 & 0,89 \\
\hline The influencer inspired me & $38 x$ & 19,59 & $81 x$ & 41,75 & $38 x$ & 19,59 & $29 x$ & 14,95 & $8 x$ & 4,12 & 2,42 & 1,09 \\
\hline The picture is beautiful. I want to ... & $57 x$ & 29,38 & $94 x$ & 48,45 & $31 x$ & 15,98 & $8 x$ & 4,12 & $4 x$ & 2,06 & 2,01 & 0,90 \\
\hline Looking at Nusa Penida on my scre... & $61 x$ & 31,44 & $86 x$ & 44,33 & $29 x$ & 14,95 & $14 x$ & 7,22 & $4 x$ & 2,06 & 2,04 & 0,97 \\
\hline
\end{tabular}




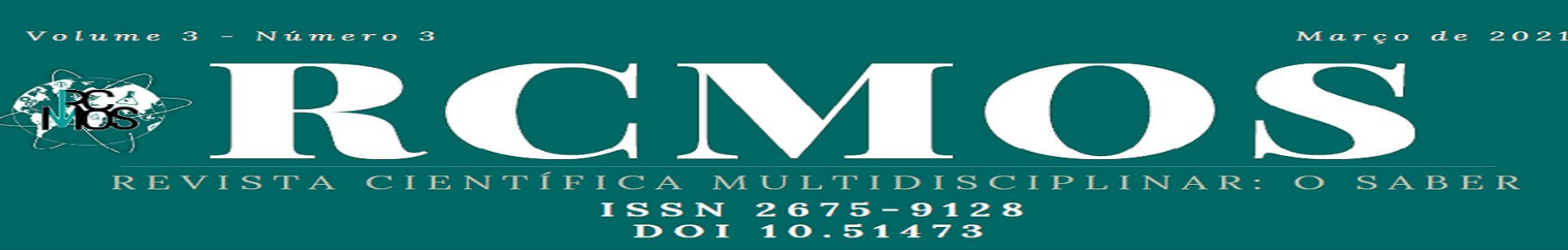

\section{Chapter 5: Data Analysis}

This master thesis aims to investigate the impact of influencer marketing on destination choice among Germany and Brazilian millennials. Additional research in terms of social media involvement and interaction among millennials was carried out to examine the factors and motivations for choosing a destination.

In this chapter, the methodical analysis was conducted from primary data collected from an online questionnaire. In addition, the general and overall findings of the analysis will address each of the different research objectives. Moreover, the results of the data and related findings will be linked to relevant literature that is applicable. The majority of the results were transferred into figures and tables using the crosstabs from the SPSS statistic. Crosstabs are a very useful tool that helps to create a bar chart with much information, and it can help to better visualize the comparison among different sets of information.

5.1 Do gender and nationality differ from social media time spending?

In the literature review chapter, Sharron and Angely (2015) argued about the importance for marketers to understand cultural differences in consumer judgment and decision-making in order to appropriately develop marketing communications strategies (Sharon \& Angely, 2015). Therefore, it essential for the author to better understand whether time spent on social media among Brazilian and German millennials varies, as both countries have different languages, cultures and beliefs. In this section question, question two and question seven were combined in order to analyze the data better. The combined results shown in Figure 25 demonstrate that Instagram is the social media platform millennials in both countries spend the most time on, with $29 \%$ of German millennials and $37 \%$ of Brazilian millennials spending the most time on there. Furthermore, Facebook comes in second for Brazilian millennials at 13\%, whereas YouTube is the runner-up for German millennials at $8 \%$. Thus, it can be assumed that Instagram is the favourite social media app of both Brazilian and German millennials. However, Brazilian millennials spend more time on Facebook (with 18 responses among Brazilians and 4 responses among Germans) and German millennials spend more time on YouTube (11 responses against 6 responses for Brazil).

Moreover, Twitter is favoured among Brazilians (6 responses versus 1 German response). Therefore, it can assume that Facebook and Twitter have a more significant number 


\section{IS SN $2675-9128$}

of usages among Brazilian millennials, while YouTube is more popular among German millennials.

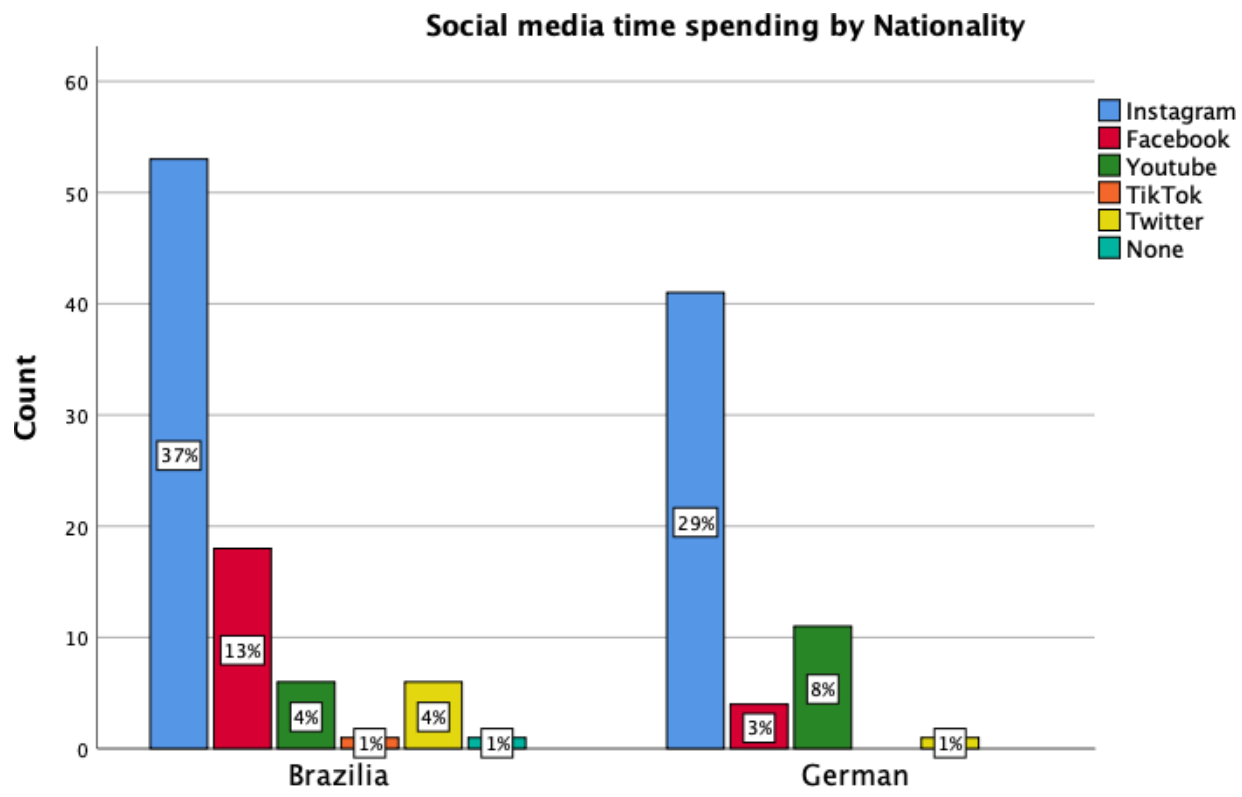

Figure 25: Social media time spending by Nationality

Source: Own illustration

This data can be combined with the literature review that discussed the preference of Insta- gram among the millennials. According to Statista (2020), half of the global population of Instagram users are age between 18 to 34 years old. Furthermore, 65\% of global Instagram audiences are between aged 18-34 years. Therefore, the findings by the study are corroborated by existing literature, suggesting a real preference for Instagram among Brazilian and German millennials compared to other social media platforms. 
Figure 26: Social media time spend by Gender

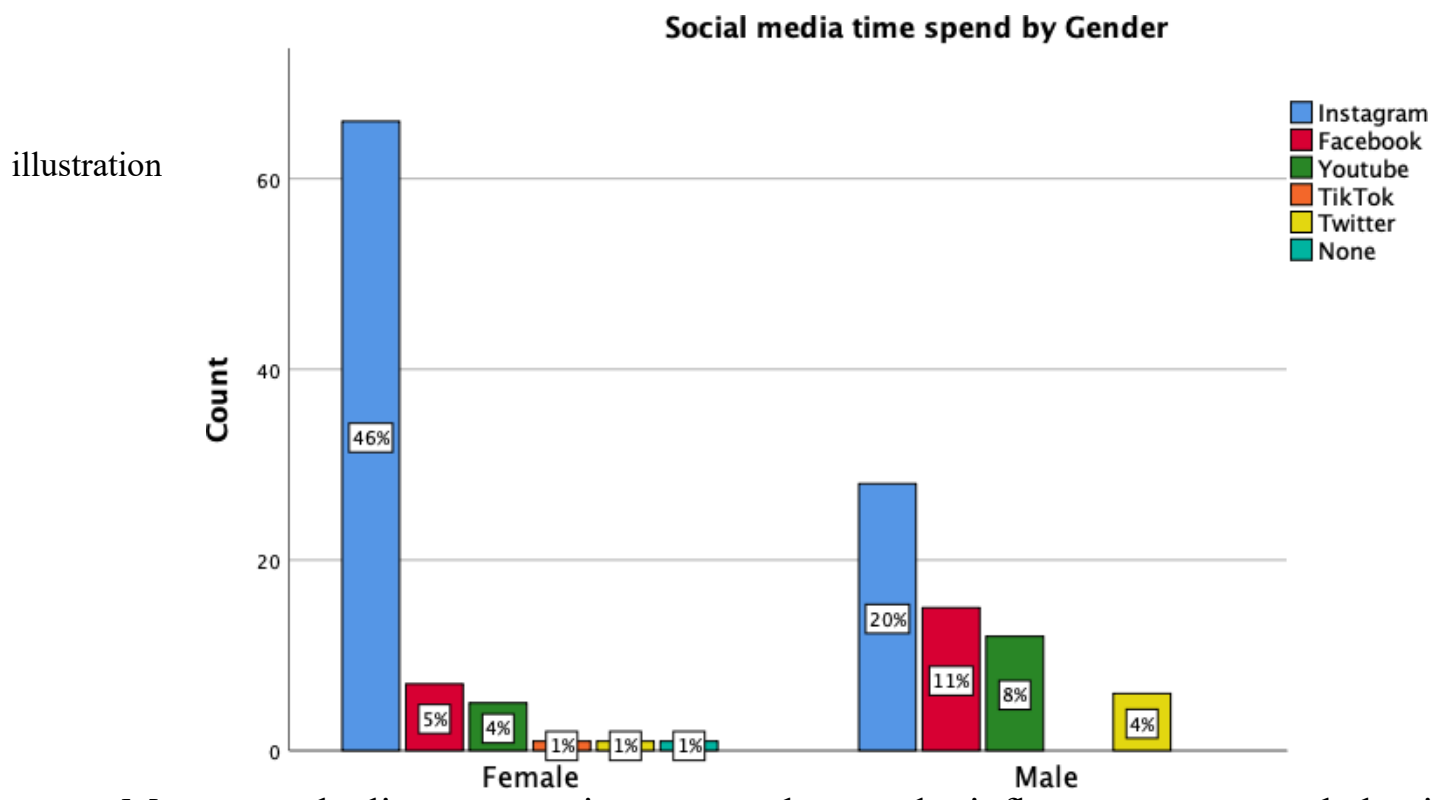

Own

Moreover, the literature review argues that gender influences consumer behavior as the roles and responsibilities vary between men and women. The expectations, characteristics, attitudes, and behaviors of men and women are subject to change over time and within different cultures. Therefore, the author combined Question 1 about gender with Question 7 about social media time spending. While Figure 26 shows a preference for Instagram across genders, females spend more time on Instagram (46\%) compared to males (19\%). On the other hand, males spend more time on Facebook (11\%) and YouTube (8\%) com- pared with females. Therefore, it is interesting to note that gender differences in social media usage are consistent with the existing literature on different consumer behavior among men and women. As can be seen, females tend to spend more time on Instagram, while time spent on social media is more evenly distributed among males. According to the literature, males and females are more likely to search for products and services from different social media. In addition, they have different needs and wants for different products or ser- vices as they have different ways of liking and purchasing it.

Findings:

$\diamond$ The majority of the participants have social media.

$\diamond$ The majority of Brazilian and German millennials prefer and spend more time on Instagram.

$\diamond$ The Brazilian millennials spend more time on Facebook and Twitter compared with the Germans. 
$\diamond$ The German millennials spend more time on YouTube.

Overall, Brazilian and German millennials have social media, and Instagram has been the preferred social media platform among both participant groups. In addition, gender and nationality are a source of variation in social media usage: Women tend to use and spend more time on Instagram, while men tend to use YouTube and TikTok more.

\subsection{Where do German and Brazilian millennials look for their travel information?}

It is crucial to understand in this section where Brazilian and German millennials look for their travel information. Participants were given nine different options on the online questionnaire to choose, such as advertising brochures, blogs, family and friends recommendations, magazines/newspapers, online agency, social media, television, television/movie series, and travel agency. Participants of the online questionnaire stated their travel information is mainly coming from family and friends' recommendations. Figure 27 shows that $56 \%$ of Brazilian millennials and $44 \%$ of German millennials use family and friends as sources for travel information.

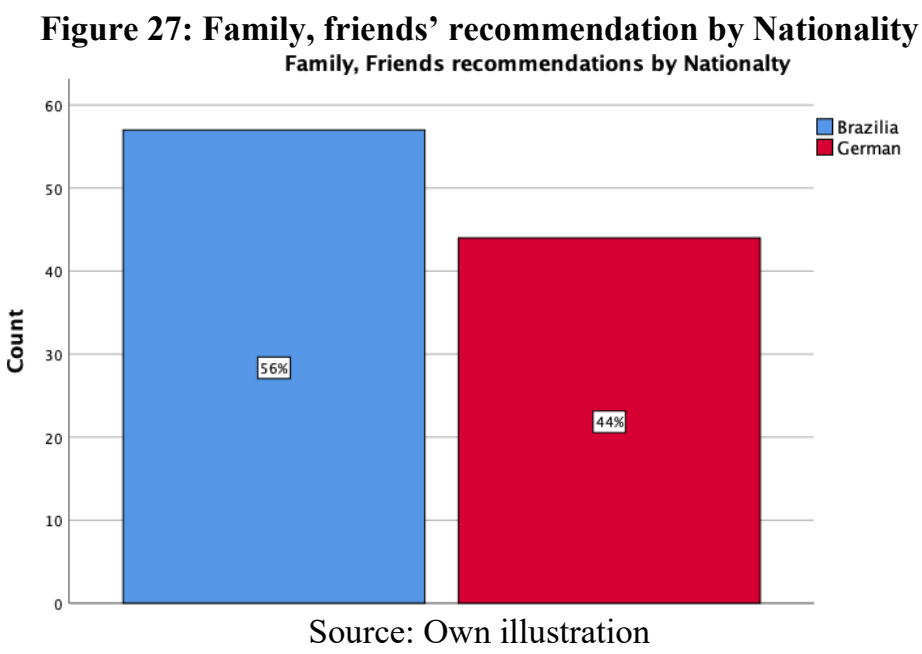

In addition, the second-highest category where German and Brazilian millennials look for travel information was on social media. Figure 29 shows that $59 \%$ of Brazilian millennials looked for such information on social media, while only $41 \%$ of German millennials also did so. 


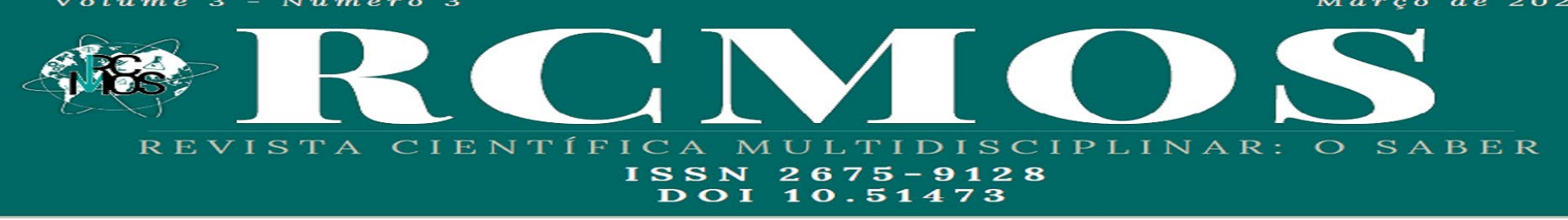

engage in such a behavior. In this this study of choosing a travel destination, the behavioral intention refers to the intention of the German and Brazilian millennials to choose a particular destination and the willingness to travel to this destination. In the case of this study, the main measurement of behavioral intention is coming from friends and family recommendations as well as social media, which acts like a positive e-world of mouth.

However, an interesting finding on Figure 29 shows that Brazilian preferer to consult with travel agencies at a much higher rate $(76 \%)$ than Germans $(24 \%)$.

Figure 29: Travel Agency by Nationality

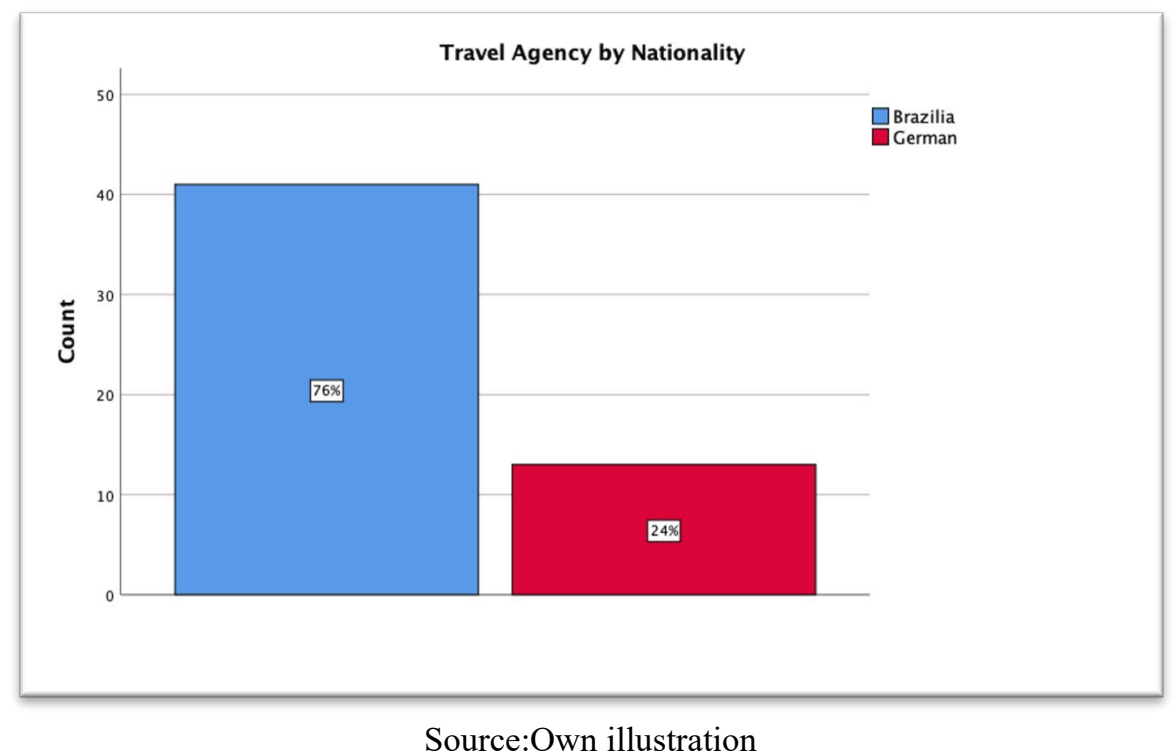

Another finding shown in figure 30 demonstrates that $64 \%$ of Brazilian respondents tend to look for travel recommendations on television and telenovelas, while only $36 \%$ of German millennials do so. Studies have shown that when Brazilian people watch an on-air telenovela, the number of researches associated with a particular destination portrayed in the telenovela increase. Therefore, Brazilian are influenced by television at higher rates when looking for travel recommendations. 


\section{S N $2675-9128$
DOI 10.51473}

Figure 30: Television/Movies/Series by Nationality

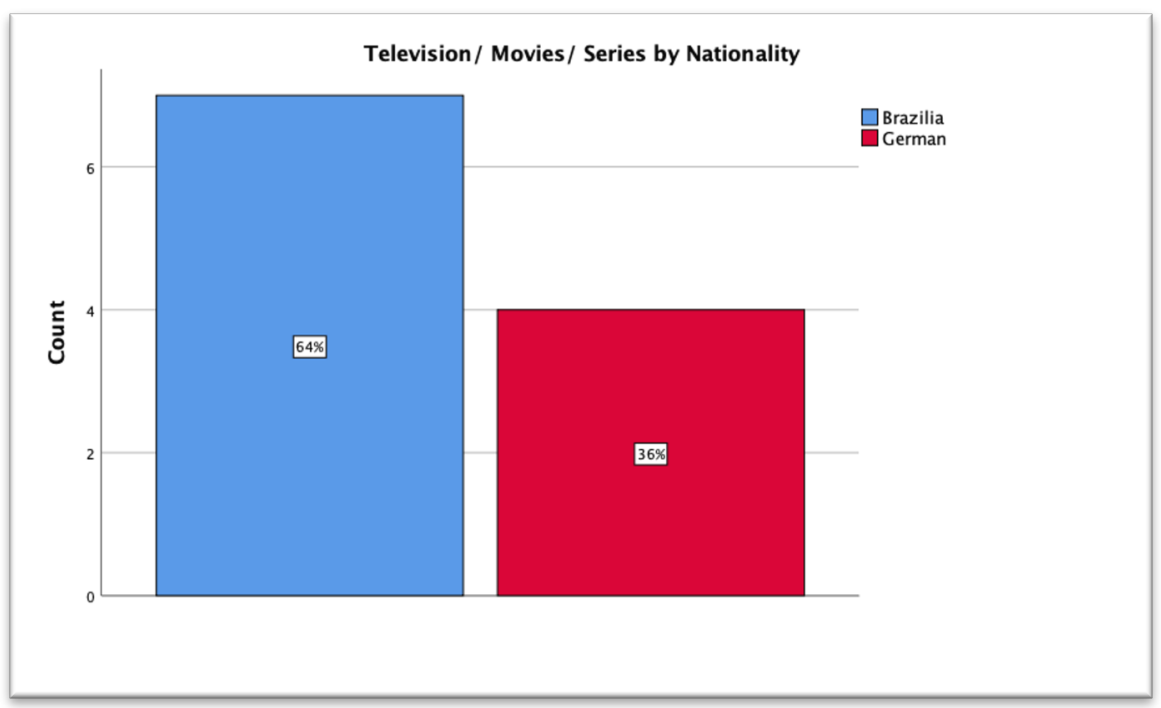

Source: Own illustration

Findings:

$\diamond$ Family and friends account for the most viewed content on social media.

$\diamond$ Family, friends are the preferred source for recommendations on potential destinations.

$\checkmark$ Social media is the second-highest source for recommendations on potential destinations.

5.3 What are the main motives for German and Brazilian millennials to choose a travel destination?

To assess the main motives of choosing a travel destination, the participants answered about which attractions and qualities make them choose a travel destination. Figure 31 shows that culture, history, and theme parks are the most important attractions for the Brazilian millennials, with each having $13 \%$. For the German millennials beach, sports and water are the most important, with $21 \%$. Cuisine and culture are tied in second place with $8 \%$ each for the German millennials. 
Figure 31: Beach, Sports water by Nationality

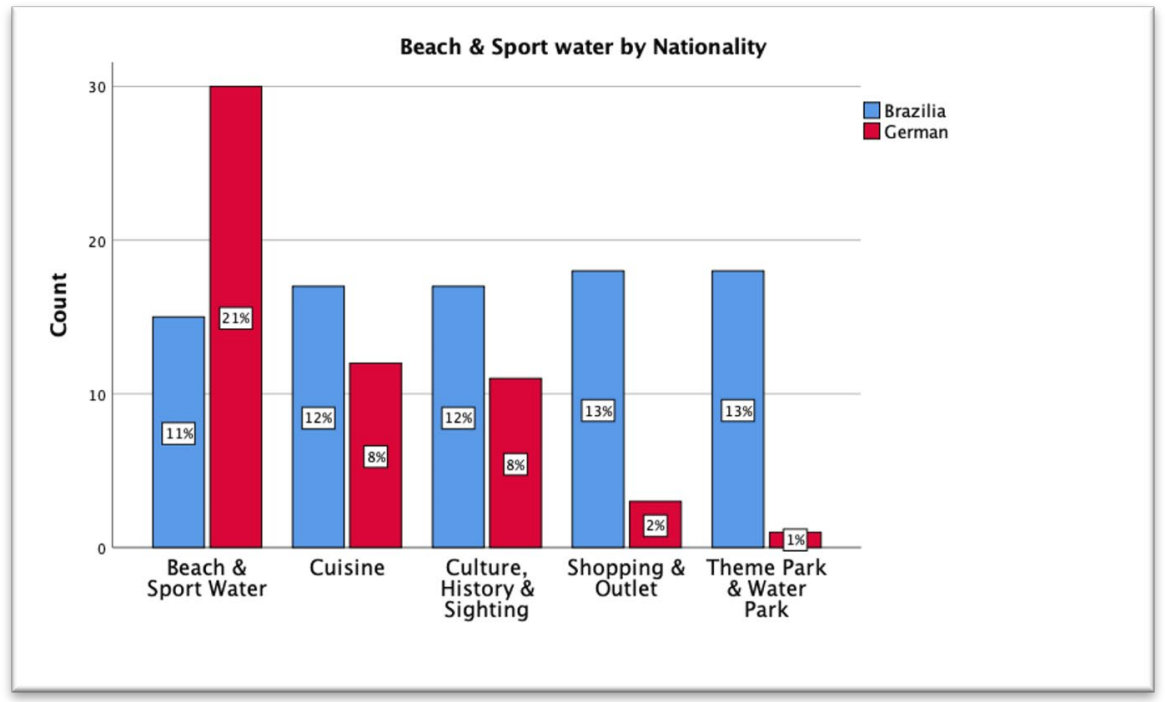

Source: Own illustration

Findings:

$\diamond$ The most important attractions among Brazilian and German millennials are beach and culture in general.

$\diamond$ Beach \& sport water is the most preferred attraction among German millennials.

$\diamond$ Shopping and theme park is the most preferred attractions among Brazilian millennials.

Overall, it is essential to gain knowledge and understanding about individual wants and needs regarding their travel choices, as they are the main reasons that explain why individuals want to travel away from their home and avoid their daily routine. Different studies have found that Individuals travel because they are pushed and pulled by forces of motivation. Thus, travel marketers need to apply the push and pull factors effectively. This gives a competitive advantage to marketers who are better at targeting travelers by offering the right destination attraction. When it comes to the preferred attractions by German millennials, it is important to acknowledge that the results observed in the survey are in line with existing literature on preferences among German tourists. The literature suggests that Germans are very fond of a warm climate, with their favorite travel destinations being Spain, Italy, and Asia. In addition, Germans tend to have a preference for destinations involving hiking, beach or bathing, city breaks, cruises, and cycling trips. This is consistent with the findings of this survey, which shows that destinations with beaches and water sport opportunities are preferred among German millennials. The literature suggests that Brazilian tourists are interested in activities such as 


\section{Volume 3 - Número 3

$\diamond$ The most important attractions among Brazilian and German millennials are beach and culture in general.

$\diamond$ Beach \& sport water is the most preferred attraction among German millennials.

$\diamond$ Shopping and theme park is the most preferred attractions among Brazilian millennials.

Overall, it is essential to gain knowledge and understanding about individual wants and needs regarding their travel choices, as they are the main reasons that explain why individuals want to travel away from their home and avoid their daily routine. Different studies have found that Individuals travel because they are pushed and pulled by forces of motivation. Thus, travel marketers need to apply the push and pull factors effectively. This gives a competitive advantage to marketers who are better at targeting travelers by offering the right destination attraction. When it comes to the preferred attractions by German millennials, it is important to acknowledge that the results observed in the survey are in line with existing literature on preferences among German tourists. The literature suggests that Germans are very fond of a warm climate, with their favorite travel destinations being Spain, Italy, and Asia. In addition, Germans tend to have a preference for destinations involving hiking, beach or bathing, city breaks, cruises, and cycling trips. This is consistent with the findings of this survey, which shows that destinations with beaches and water sport opportunities are preferred among German millennials.

The literature suggests that Brazilian tourists are interested in activities such as beach, history, sighting, gastronomy, shopping, or outlet store (Xavier, 2019). Here, the existing literature is again in line with the results of the survey, since it also found Brazilian millennial destination choices to be influenced by shopping opportunities. It is essential to acknowledge that most import goods such as clothes and electronic products are very ex- pensive in Brazil.

Therefore, the findings of both the literature review and primary data collection prove that Brazilian and German millennials have different preference for attractions when choosing travel destinations. At the same time, it is interesting to note that there appear to parallel trends between general country-specific attraction preferences found in the literature and the attraction preferences espoused specifically by millennials in the context of primary data collection for this thesis.

5.5 What are the main barriers/factors for German and Brazilian millennials not to choose a destination? 
To further optimise the way in which tourism marketers can target German and Brazilian millennials, it is essential to investigate the main barriers or factors that influence millennials from both those countries to discard a destination as a potential travel choice. The author listed seven main factors, such as bad weather, bad/negative reviews, lack of infrastructure, language barrier, price exchange rate, security, and visa requirement as possible barriers for choosing a destination. These factors are listed in Table 7. However, the below figures will only illustrate the most relevant factors with higher percentages.

Table 7: Factors to "Not" choose a destination by Nationality

\begin{tabular}{|c|c|c|c|c|c|c|}
\hline \multicolumn{7}{|c|}{ Factors to "Not" choose a destination } \\
\hline & \multicolumn{6}{|c|}{ Cases } \\
\hline & \multicolumn{2}{|c|}{ Valid } & \multicolumn{2}{|c|}{ Missing } & \multicolumn{2}{|c|}{ Total } \\
\hline & $\mathrm{N}$ & Percent & $\mathrm{N}$ & Percent & $\mathrm{N}$ & Percent \\
\hline $\begin{array}{l}\text { Bad weather * } 2 \text {. What } \\
\text { is your nationality? }\end{array}$ & 63 & $44.4 \%$ & 79 & $55.6 \%$ & 142 & $100.0 \%$ \\
\hline $\begin{array}{l}\text { Bad/negative reviews * } \\
2 \text {. What is your } \\
\text { nationality? }\end{array}$ & 100 & $70.4 \%$ & 42 & $29.6 \%$ & 142 & $100.0 \%$ \\
\hline $\begin{array}{l}\text { Lack of Infrastructure * } \\
2 . \text { What is your } \\
\text { nationality? }\end{array}$ & 73 & $51.4 \%$ & 69 & $48.6 \%$ & 142 & $100.0 \%$ \\
\hline $\begin{array}{l}\text { Language barrier * } 2 \text {. } \\
\text { What is your nationality? }\end{array}$ & 19 & $13.4 \%$ & 123 & $86.6 \%$ & 142 & $100.0 \%$ \\
\hline $\begin{array}{l}\text { Price / Exchange rate * } \\
2 . \text { What is your } \\
\text { nationality? }\end{array}$ & 63 & $44.4 \%$ & 79 & $55.6 \%$ & 142 & $100.0 \%$ \\
\hline $\begin{array}{l}\text { Security * } 2 . \text { What is } \\
\text { your nationality? }\end{array}$ & 89 & $62.7 \%$ & 53 & $37.3 \%$ & 142 & $100.0 \%$ \\
\hline $\begin{array}{l}\text { Visa requirement * } 2 \text {. } \\
\text { What is your nationality? }\end{array}$ & 28 & $19.7 \%$ & 114 & $80.3 \%$ & 142 & $100.0 \%$ \\
\hline
\end{tabular}

Source: Own illustration

Figure 32 shows that $87 \%$ of Brazilian millennials responded that price and exchange rate are barriers to choosing a given travel destination. 


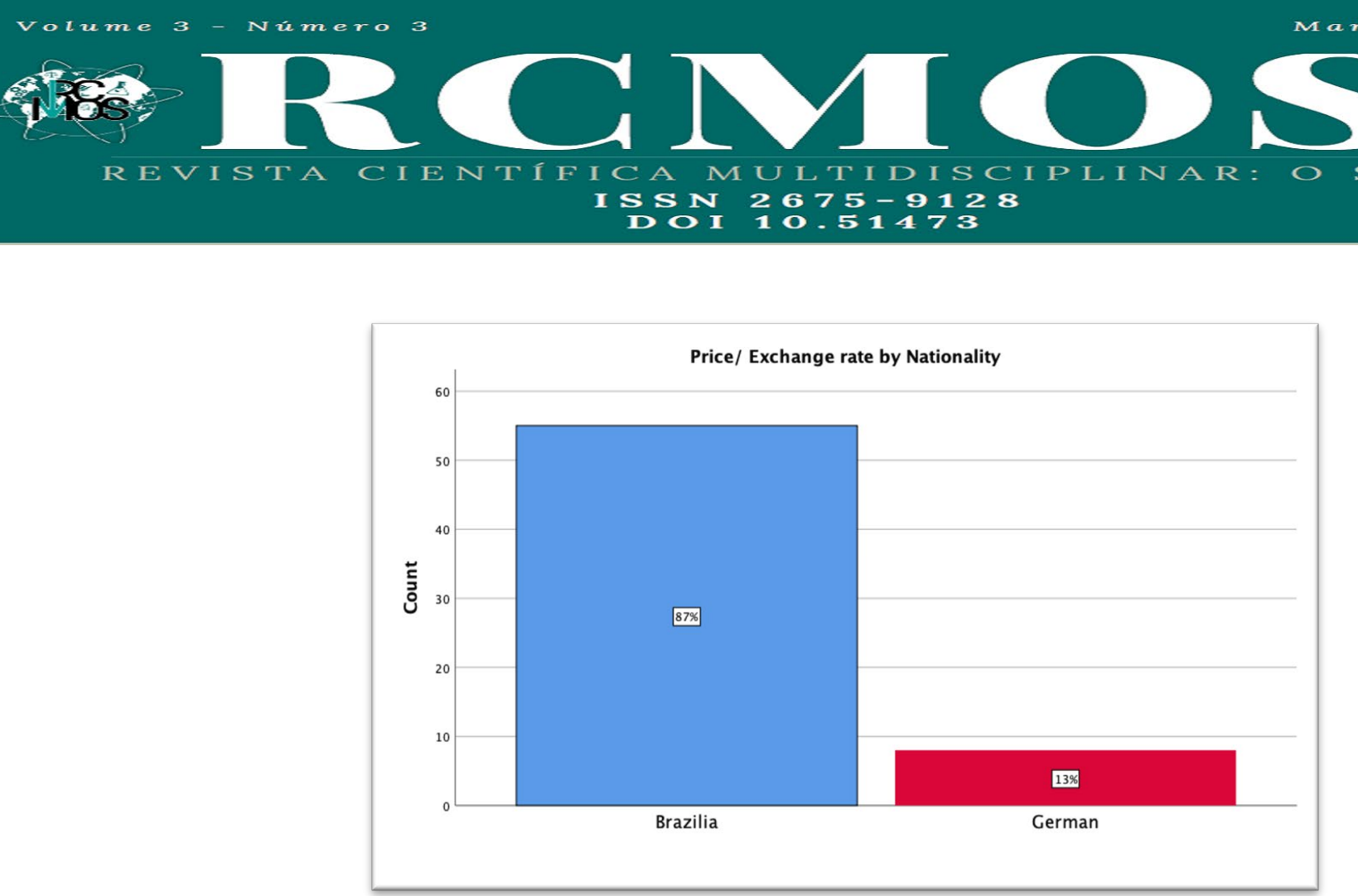

Figure 33: Price/ Exchange rate by Nationality

Source: Own illustration

Figure 33 shows that $73 \%$ of Brazilian millennials responded that lack of infrastructure is a barrier to choosing a given travel destination.

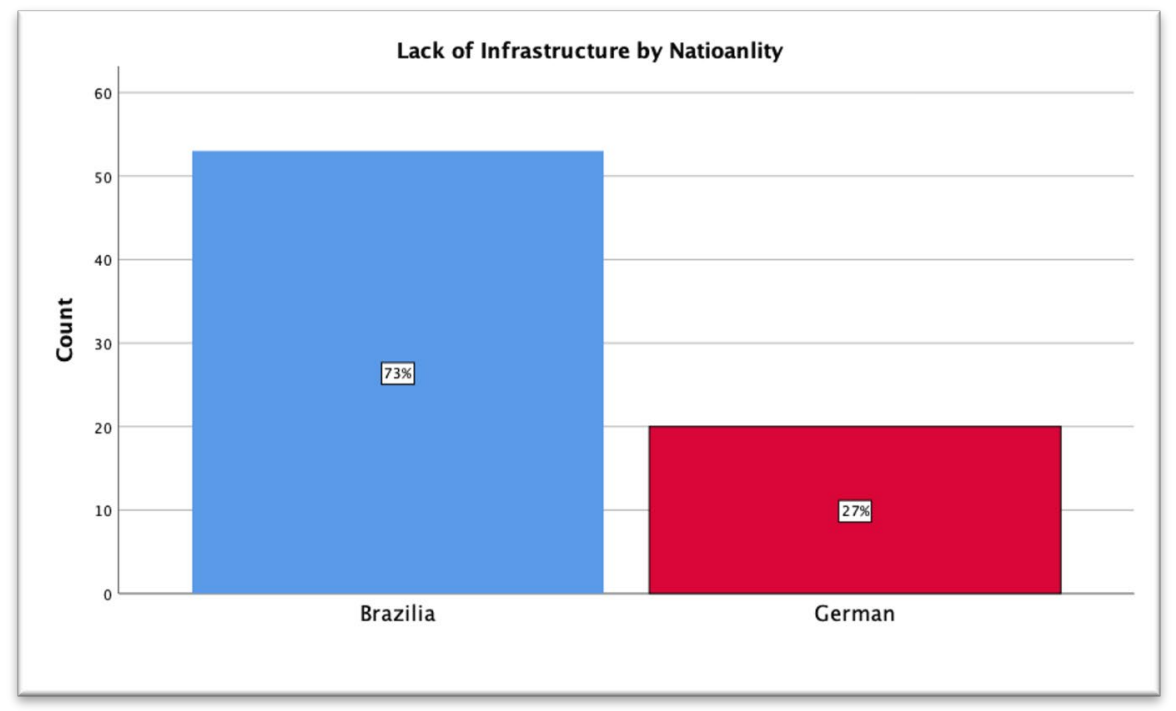

Figure 34: Lack of infrastructure by Nationality Source: Own illustration

Figure 34 shows that $79 \%$ of Brazilian millennials indicated that language barriers are one of the barriers preventing them from choosing a given travel destination. 


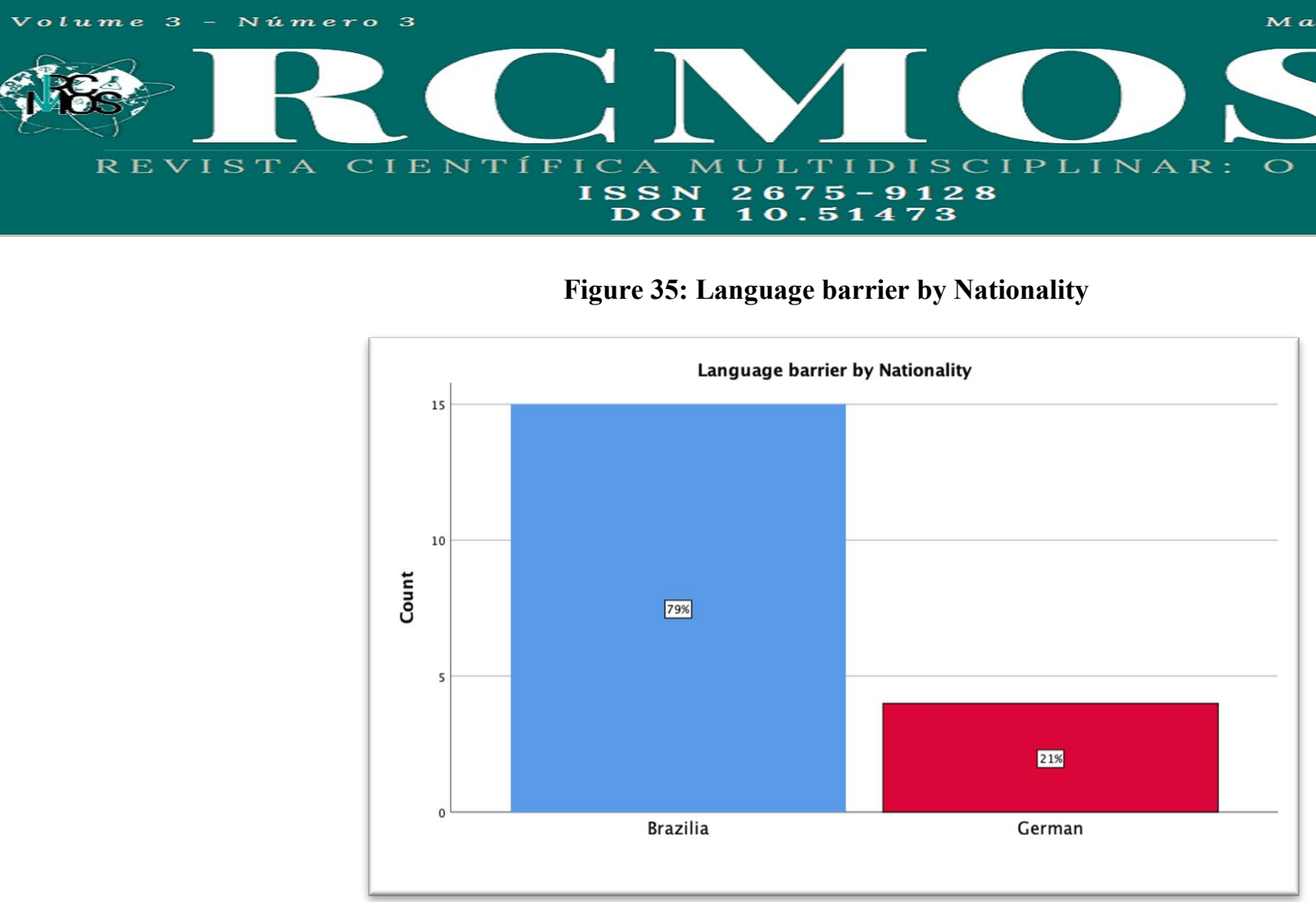

Source: Own illustration

Figure 35 shows that $68 \%$ of Brazilian millennials indicated that bad/ negative reviews are one of the barriers that prevent them from choosing a given travel destination.

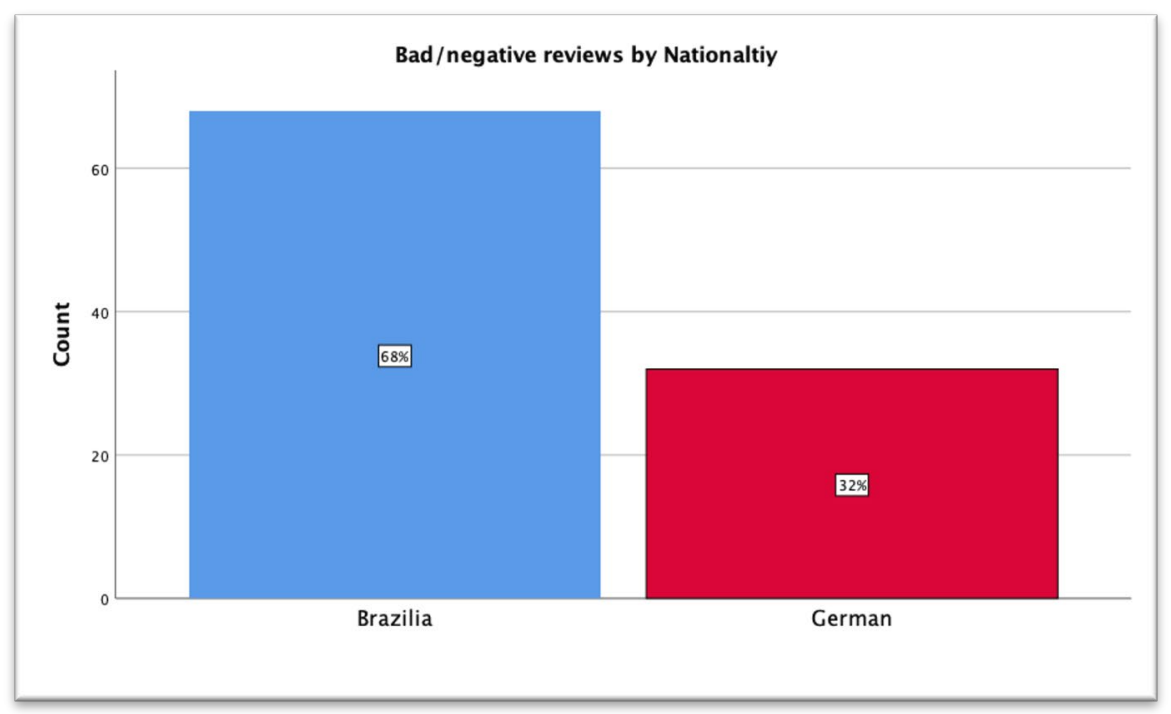

Figure 36: Bad/Negative review by Nationality

Source: Own illustration

Figure 36 shows that $57 \%$ of German millennials indicated in their responses that security is a barrier that prevents them from choosing a given travel destination. 
to acknowledge the culture difference between countries and a strategy that will be effective for the different nations when choosing a specific travel destination.

However, it is important to take into consideration that these factors are time-variant and potentially volatile. Nowadays natural disasters are occurring constantly. For example, the spread of the Coronavirus pandemic starting in February/March 2020 has majorly affected several industries, including tourism. Due to containment measures put in place by several countries, people from different nations have to deal with travel restrictions to particular destinations. Given the current scenario, Germans are not allowed to travel to certain countries and Brazilians have been banned from entering multiple countries including the European Union, due to Brazil currently being one of the countries with highest contamination risk. Other relatively unpredictable natural disasters include the bushfires in Australia and the floods in Japan, which will affect tourist demand due to high risk in the short and medium term. Therefore, it is important for tourism managers to take security concerns into consideration when marketing certain destinations while also being mindful that fairly un- predictable events such as natural disasters might alter destination preferences suddenly.

5.6 How German and Brazilian millennials interact in their social media on a travel destination?

To assess the interaction of German and Brazilian millennials on their social media, the author combined question two of the online survey with Questions 12 and 13 using the crosstabulation of SPSS. In this section, the author combined the Question 2 about nationality with Question 12 about participant role on social media. Figure 37 illustrates the role of participation in social media by nationality. The main findings suggest that both Brazilians $(35 \%)$ and Germans (25\%) millennials are engaged in social media but rarely post. How- ever, $23 \%$ of Brazilians are more active and post regularly compared to only $5 \%$ of Ger- mans. German millennials are more likely $(9 \%)$ to be silent observers as opposed to Brazilians (3\%). 
REVISTA CIENTIFICA MUITIDISCIPIINAR: O SABER ISSN $2675-9128$

Figure 38: Role/Participants on social media by Nationality

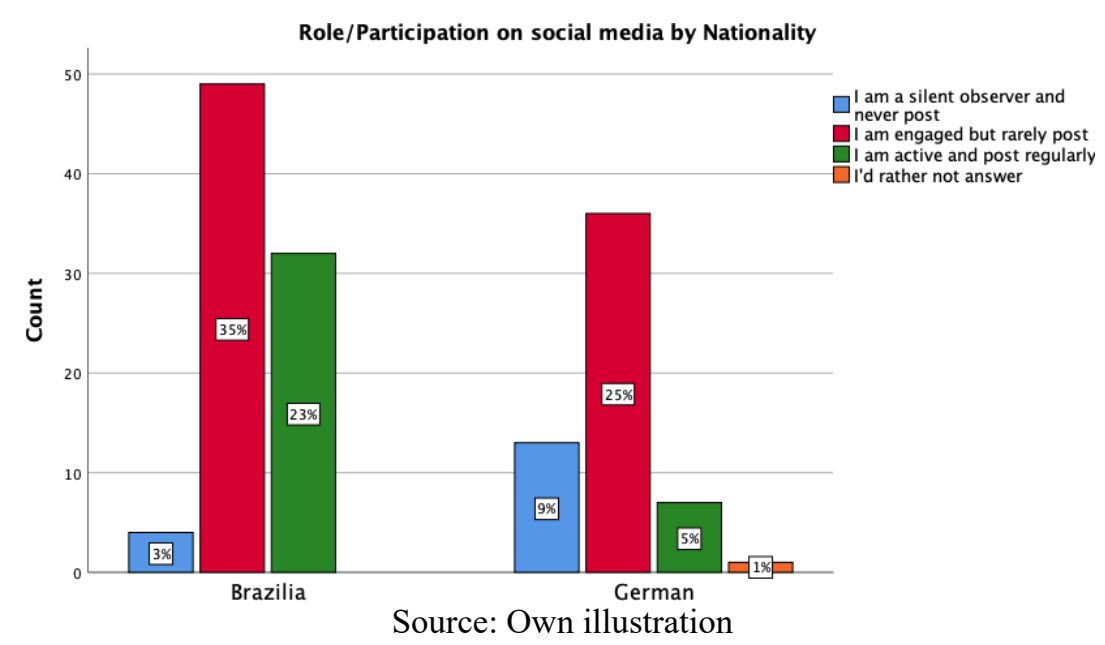

Moreover, it is important to understand how regularly Germans and Brazilians post their travel pictures on social media. Figure 38 shows that most German respondents (37\%) and most Brazilian respondents (30\%) report "sometimes" posting their travel picture on social media. However, Brazilian millennials are much more likely to always post their pictures on social media $(25 \%)$ compared to only $8 \%$ of German millennials. It is essential to understand that different cultures can have different behaviours towards sharing travel pictures on social media.

Figure 39: Post travel picture on social media by Nationality

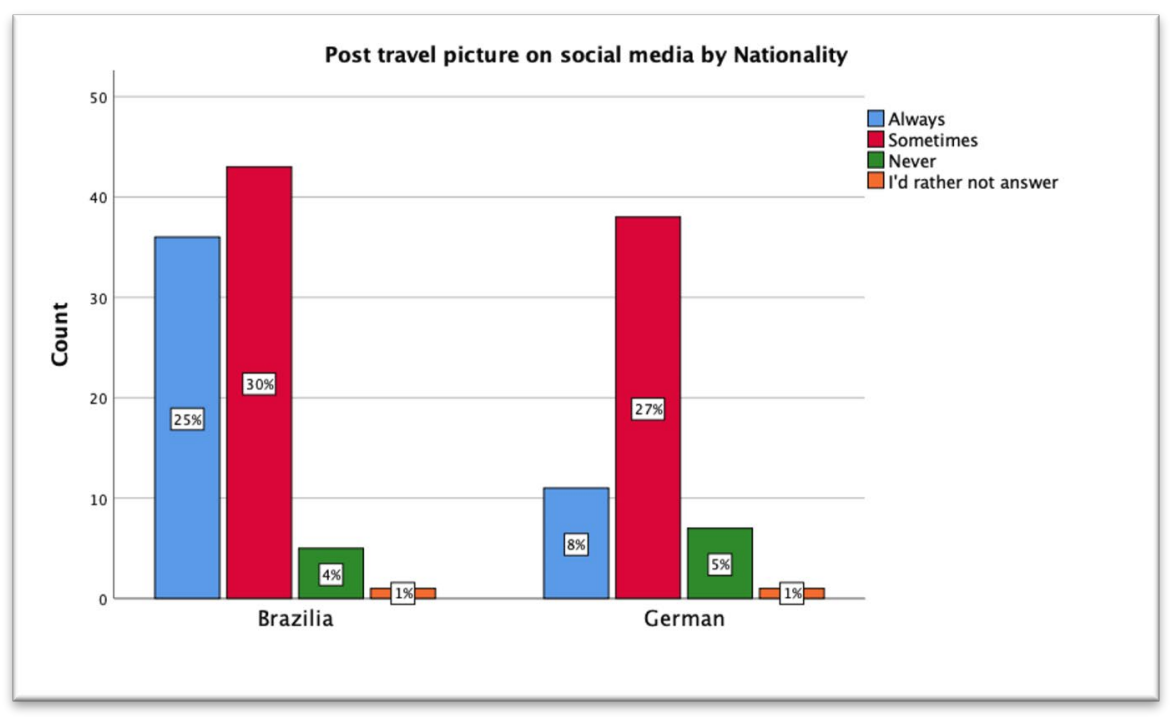

Source: Own illustration

Therefore, the behaviour of posting a travel pictures among the Brazilian and German millennials can be best combined with the literature review on the subjective norm. The 
subjective norm relates to the pressure exerted by society onto the individual in relation to engagement in a particular behavior. The individual then adapts in the face of such pressure and develops a certain behavior. The subjective norm can be determined by individuals posting pictures and their evaluation on how other see and perceived them. In addition, cultural differences will affect the "openness" of different nationalities to posting on social media. Culture will also affect the perception of what individuals are "allowed" to post. For the purpose of this study, it can be assumed that Brazilian millennials are more likely to share their travel pictures, than the German millennials.

Furthermore, it was essential to acknowledge how regularly Brazilian and Germany millennials view travel influencers. Figure 39 illustrates that "sometimes" has a higher number of respondents among Brazilian millennials with 38\%, and German millennials with 17\%, whereas “once a day" and "every day” has a higher response among German's millennials (7\%) compared to Brazilian millennials (1\%). However, 4\% of Brazilians view travel influencers weekly, whereas among German millennials no respondents viewed such influencers every week.

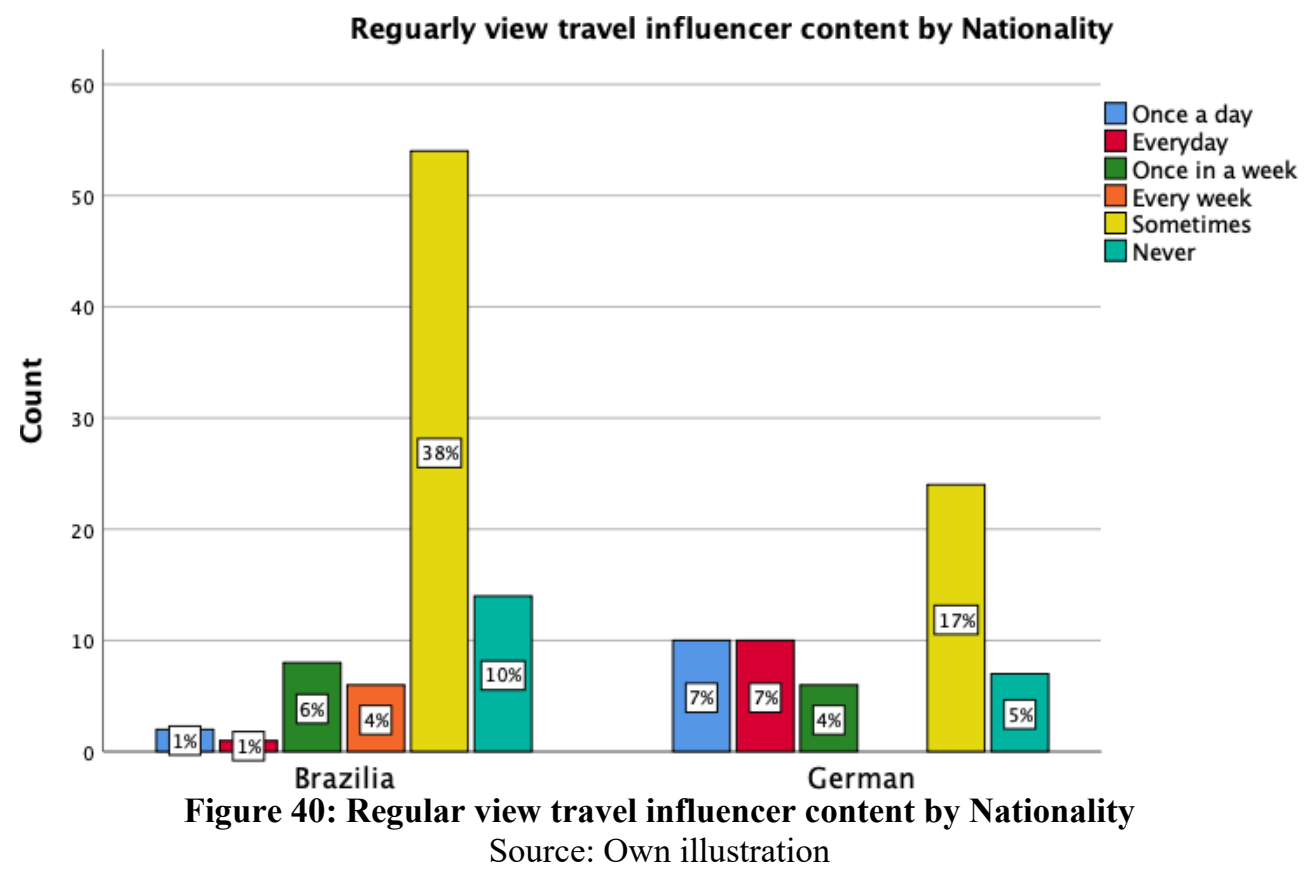

Findings: 
$\diamond$ The majority of Brazilian millennials are "engaged but rarely post."

$\diamond$ Brazilian millennials are "more active and post regularly" compared to German millennials.

$\diamond$ A higher proportion of German millennials classify themselves as "silent observers"

$\diamond$ The majority of German and Brazilian millennials view travel influencers "sometimes."

Overall, it can be said that, due to the cultural differences among the Brazilian and German millennials, we can assume that Brazilians are much more interactive on social media and are more likely to share their experiences, whereas Germans are more reserved when it comes to sharing their experience on social media. However, German millennials seem to enjoy viewing travel influencer contents more on their social media compared to Brazilians. Therefore, travel marketers should be aware when creating and targeting content on social media to optimize content to the different preferences of Brazilian and German millennials.

\subsection{How trustworthy is Influencer Marketing for German and Brazilian millennials?}

To further investigate the impact of influencer marketing among German and Brazilian millennials, the author asked the participants how trustworthy they find influencer marketing. Figure 40 shows that Brazilians are more inclined to find influencer travel recommendations valuable compared to Germans. $13 \%$ strongly agree and 39\% agree with the statement, while only $4 \%$ of Germans strongly agree and $18 \%$ agree with the statement. However, both groups had had a relatively high response to "neither agree, nor disagree", even if Germans appear to be more sceptical here as well. 
Figure 41: Influencer trustworthy by Nationality

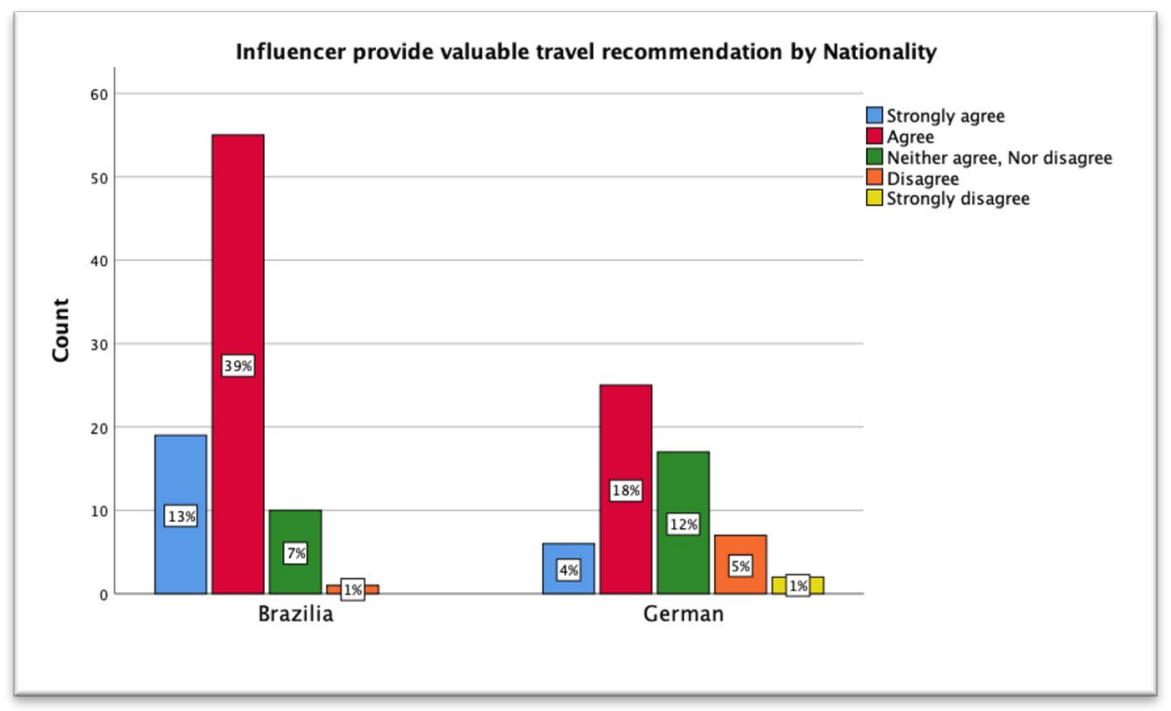

Source: Own illustration

In addition, the author segregated the responses to Question 17 on influencer travel recommendations by nationality. Figure 41 illustrates that Brazilians tend to agree more with the statement that influencers provide valuable travel recommendations compared with German millennials. In addition, Brazilian millennials have a higher number of "strongly agree" with $13 \%$ a response compared with a $4 \%$ response by German millennials. How- ever, "disagree" with 5\% and "strongly disagree" with 16\% has a higher number among German millennials.

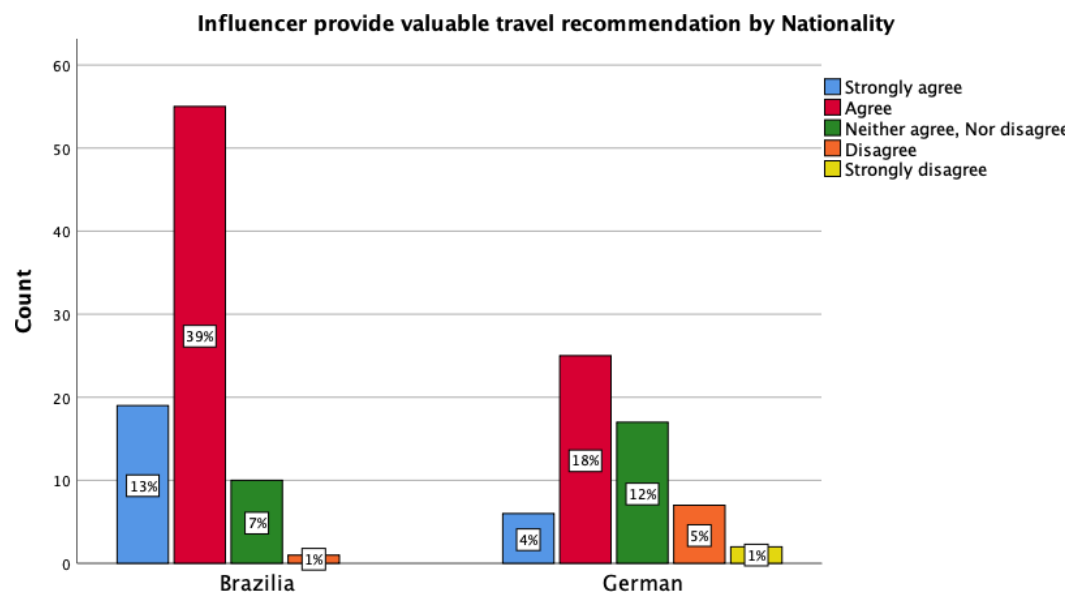

Figure 42: Influencer provide valuable recommendation by Nationality

Source: Own illustration

Findings:

$\diamond$ The majority of Germans and Brazilians neither agree nor disagree that the influencer is trustworthy. 
$\diamond$ Brazilian millennials have a slightly higher number of people in agreement that influencers are trustworthy compared to German millennials.

$\diamond$ The majority of Brazilian and German millennials agree that influencers provide valuable travel recommendations.

Overall, it can be assumed that German and Brazilian millennials are particularly uncertain about how trustworthy an influencer is. However, both German and Brazilian millennials agreed that influencers provide valuable travel recommendations. The above findings pro- vide essential information for both the marketer and influencer in terms of the need to develop a strategy that makes influencers more trustworthy. In addition to better influencing and attracting Brazilian and German millennials, trust is important when attempting to create valuable travel recommendations.

5.8 How satisfied have German and Brazilian millennials been with Influencer Marketing recommendations?

To further investigate the impact of influencer marketing on Brazilian and German millennials is essential to understand how satisfied they are with influencer marketing recommendations. The author asked the participants on the online survey to state their opinion on five different statements. This will help the author have a better understanding of how satisfied they are with influencer marketing recommendations.

The first statement is that influencers draw attention to new products/ trends. Figure 42 shows that both German (34\%) and Brazilian (54\%) millennials "strongly agree and agree". However, $1 \%$ of the German millennials "disagree". 
Figure 43: Influencer draw attention to new products/trends by Nationality

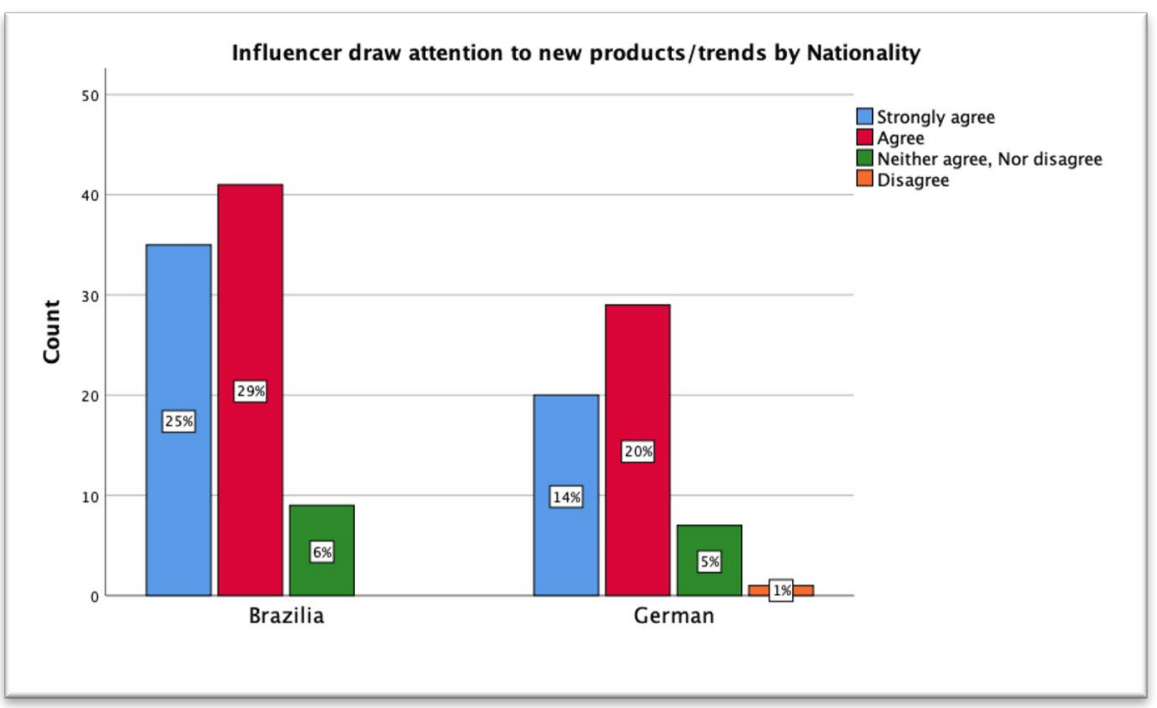

Source: Own illustration

The second statement is about whether influencers help to choose a destination. Table 43 shows that more Brazilian millennials (30\%) agree that influencers help choose a destination, while only $15 \%$ of Germans do so. In addition, German millennials have higher response in the "strongly disagree" category with $4 \%$ against a $0 \%$ response rate by Brazilian's millennials.

Figure 44: Influencers help me to choose a destination by Nationality

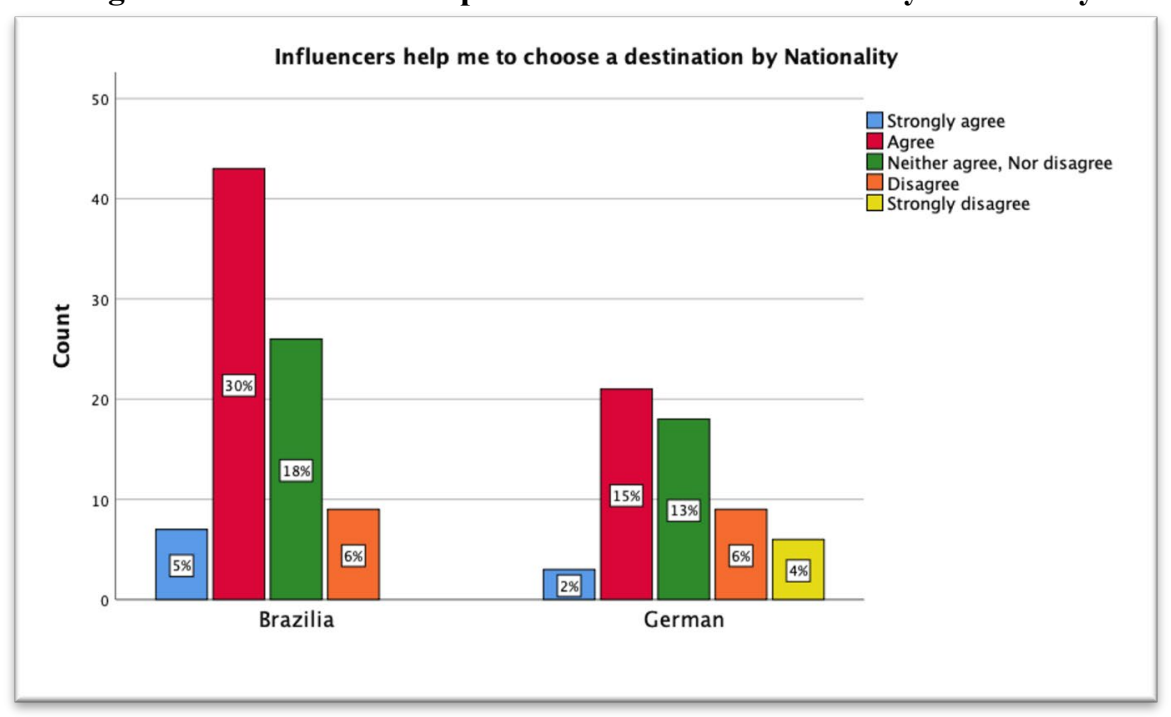

Source: Own illustration

The third statement is about whether travel influencers inspire and make us to want to travel. Figure 44 illustrates that $24 \%$ of Germans and $38 \%$ of Brazilians agreed that that travel 
influencers always inspire and make them want to travel. However, 14\% of Brazilians and 12\% of Germans "neither agree, nor disagree" with this statement.

Figure 45: Travel influencer inspire me and make me want to travel by Nationality

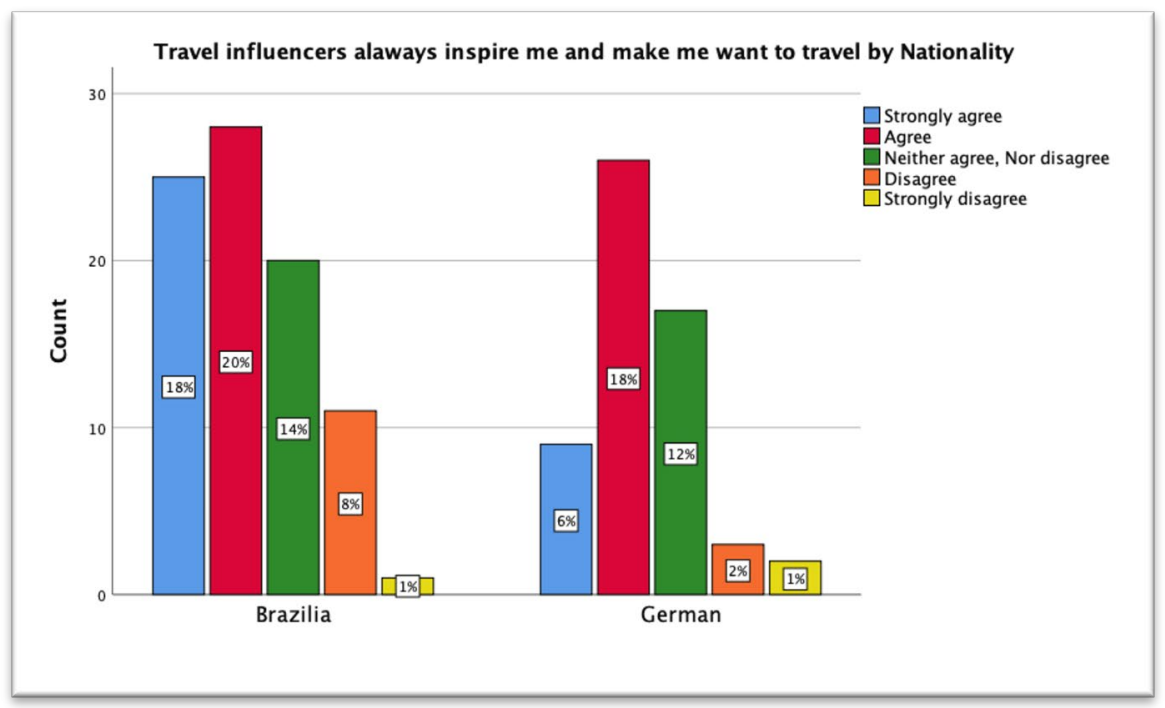

Source: Own illustration

The fourth statement is whether influencers help to choose a destination. Table 45 shows that both Brazilians with 30\% and Germans with 15\% "agree" that influencers help to choose a destination. However, the $18 \%$ of Germans and $13 \%$ of Brazilians selected "neither agree, nor disagree".

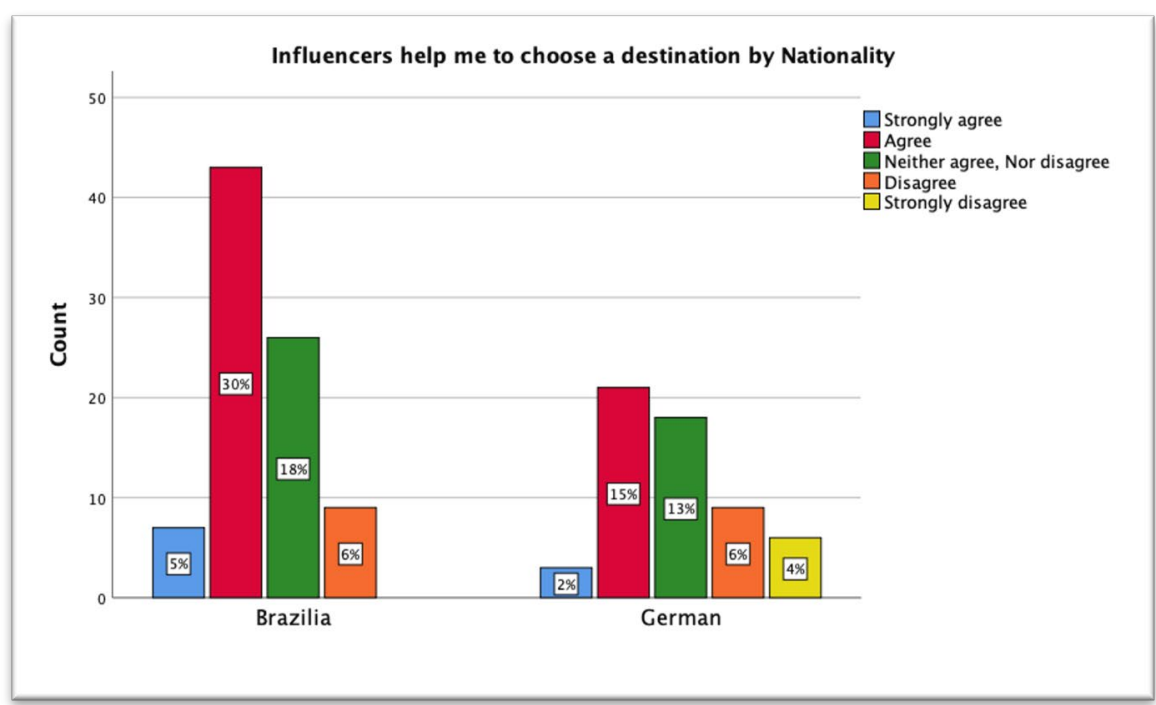

Figure 46: Influencer help me to choose a destination by Nationality Source: Own illustration 
The fifth statement is about whether seeing a destination post on social media makes the Brazilian and German millennials want to visit that place. Figure 46 demonstrates that $25 \%$ of Brazilian millennials strongly agree compared to only $7 \%$ of Germans. However, both Brazilian $(25 \%)$ and German (23\%) millennials have a similar response to" agree"

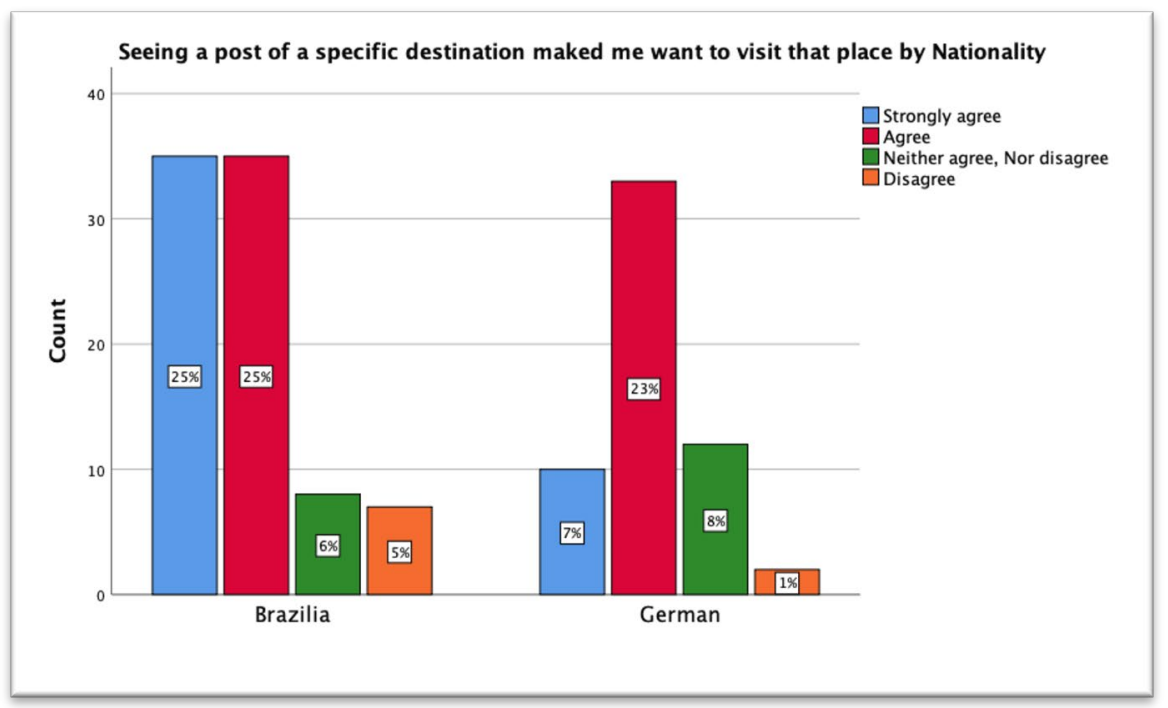

Figure 47: Seeing a post a specific destination made me want to visit that place by Nationality Source: Own illustration

The sixth statement is about whether seeing a travel influencer's experience on social media can impact Brazilian and German millennials' opinions on the travel destination. Figure 47 shows that $28 \%$ of Brazilians and $20 \%$ of Germans "agree". However, both $10 \%$ of Brazilians and $11 \%$ of Germans neither agree nor disagree.

Figure 48: Seeing travel influencer experience by Nationality

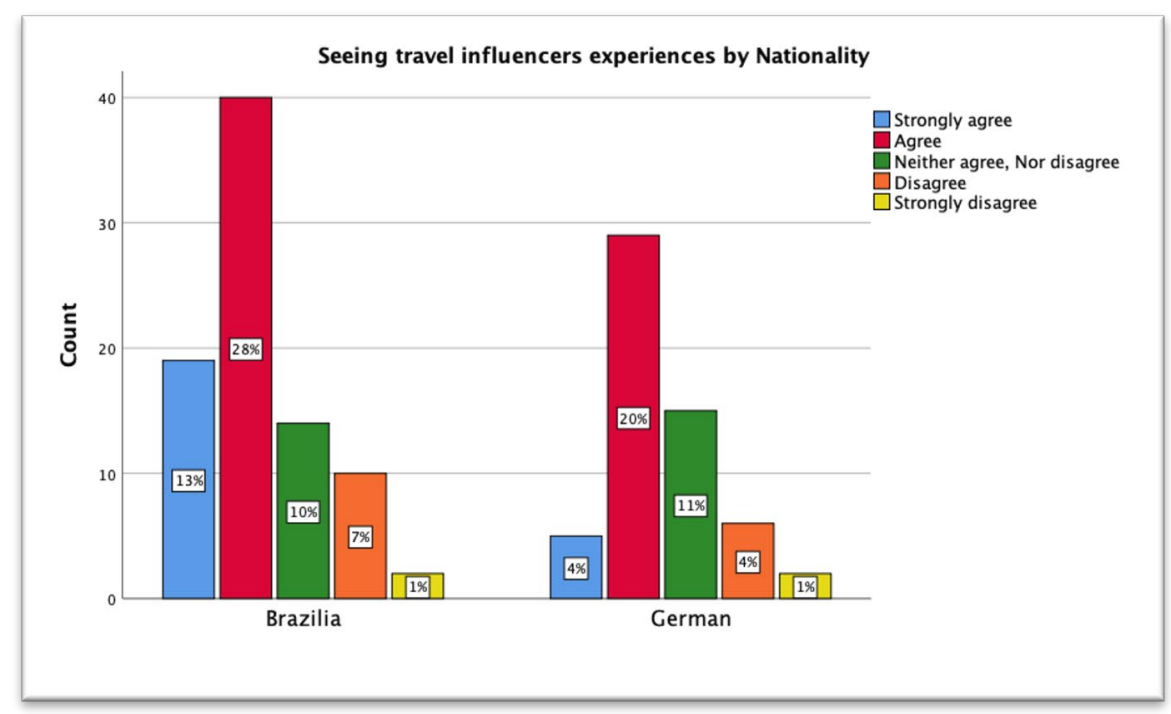

Source: Own illustration 
5.9.9. How often have German and Brazilian millennials posted their travel destination on their social media?

Figure 48 shows how often Brazilian and German millennials post their travel pictures on social media. Brazilians "always" post with $25 \%$ responses, whereas only $8 \%$ of Germans responded with "always". In addition, Brazilians have a higher response rate to "sometimes" (30\%) compared to Germans (27\%).

Figure 49: Post travel pictures on social media by Nationality

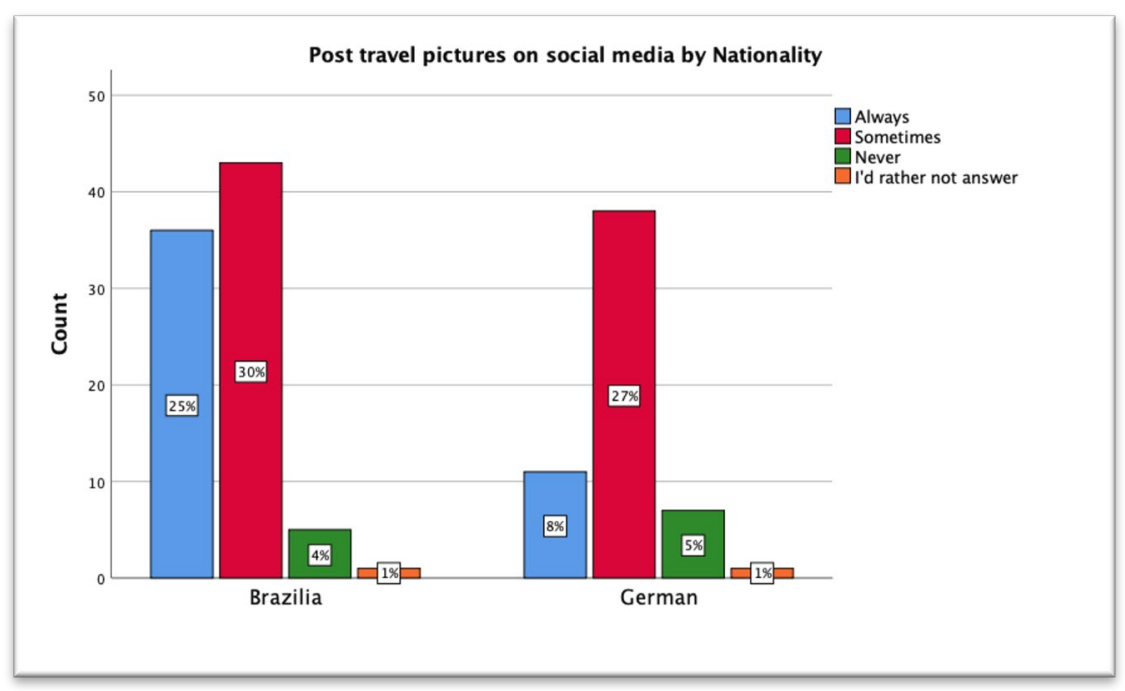

Source: Own illustration

Findings:

$\diamond$ The majority of Brazilian and German millennials "sometimes" post their travel pictures on social media.

$\diamond$ Brazilians have a higher number of "always" posts compared with the German millennials.

Overall, it is important to acknowledge that both the German and Brazilian millennials post their travel pictures on social media. This shows that both millennial groups interreact on their social media and like sharing and posting pictures. Different studies on social media have argued that social media provides a space for millennials to express their feelings, ideas, thoughts, and attitudes. Studies have revealed that social media platforms develop emotional effects of loyalty, gratification, sharing, bonding, and more interaction in brand product or service content. In addition, the Web 2.0 technology, such as social media, has gained attention 
of the travel and tourism industry as an increasing proportion of users is sharing traveling information and experience on social media.

5.9.10. Why German and Brazilian millennials use social media?

In order to gain more knowledge about why German and Brazilian millennials use social media, the author asked the participants on the online survey to rank the following statement from most important (1) to least important (9). Here the author will only discuss two statements.

Table 8 shows that both Brazilian and German millennials tend to use social media the most to stay in touch with friends.

Table 8: To keep in touch with friends

\begin{tabular}{|c|c|c|c|c|c|c|c|c|c|c|c|}
\hline \multicolumn{12}{|c|}{ To keep in touch with friends } \\
\hline \multicolumn{12}{|l|}{ Count } \\
\hline & \multicolumn{11}{|c|}{ To keep in touch with friends } \\
\hline & & $\begin{array}{c}\text { Most } \\
\text { important }\end{array}$ & 2 & 3 & 4 & 5 & 6 & 7 & 8 & $\begin{array}{l}\text { Least } \\
\text { important }\end{array}$ & Total \\
\hline \multirow{2}{*}{$\begin{array}{l}\text { 2. What is your } \\
\text { nationality? }\end{array}$} & Brazilia & 28 & 21 & 5 & 4 & 8 & 2 & 6 & 6 & 5 & 85 \\
\hline & German & 29 & 14 & 2 & 2 & 3 & 0 & 0 & 4 & 3 & 57 \\
\hline Total & & 57 & 35 & 7 & 6 & 11 & 2 & 6 & 10 & 8 & 142 \\
\hline
\end{tabular}

The second statement regards the use of social media to promote products. Table, 8 shows that both Brazilians and Germans millennials have similar ranked choices when it comes to using social media to promote products.

Table 9: To promote products

\begin{tabular}{|c|c|c|c|c|c|c|c|c|c|c|c|}
\hline \multicolumn{12}{|c|}{ To promote products } \\
\hline \multicolumn{12}{|l|}{ Count } \\
\hline & \multicolumn{11}{|c|}{ To promote products } \\
\hline & & $\begin{array}{c}\text { Most } \\
\text { important }\end{array}$ & 2 & 3 & 4 & 5 & 6 & 7 & 8 & $\begin{array}{l}\text { Least } \\
\text { important }\end{array}$ & Total \\
\hline \multirow{2}{*}{$\begin{array}{l}\text { 2. What is your } \\
\text { nationality? }\end{array}$} & Brazilia & 8 & 3 & 3 & 1 & 8 & 9 & 11 & 12 & 30 & 85 \\
\hline & German & 2 & 1 & 0 & 0 & 5 & 2 & 3 & 12 & 32 & 57 \\
\hline Total & & 10 & 4 & 3 & 1 & 13 & 11 & 14 & 24 & 62 & 142 \\
\hline
\end{tabular}

Findings:

$\diamond$ The majority of Brazilian and German millennials ranked social media to be the most important " to keep in touch with friends."

$\diamond$ The majority of Brazilian and German millennials ranked social media the least important "to promote products."

Overall, we can conclude that for both the German and Brazilian millennials, keeping in touch with friends is a priority on social media. Studies have shown that reference groups, 
Therefore, price-attractiveness is likely to play a more significant role in the destination choice of Brazilians.

5.9.12. Do travel influencer pictures impact German and Brazilian millennial's destination choices?

In this section, the author presented survey respondents with destination pictures by four main travel influencers, two from Germany and two from Brazil. As Pictures have become an essential element of social media platforms like Instagram and Snapchat, many major industries have adapted their marketing strategies to include visuals that gain customer attention. In addition, people are becoming more comfortable with sharing and posting pictures on their social media. Furthermore, the author wanted to investigate further whether the participants would recognize the influencer and if recognizing the influencer would increase their likelihood of choosing a destination because they know the influencer. The author also gave four different pictures from different destinations for participants to agree whether they want to go there after looking at the picture.

The first picture was a picture of a desert with the Dubai city in the background. The author wanted to give the participants the feeling of heat and desert sand. In addition, the picture featured the tallest building in the world, the Burj Kalifa. Dubai has been a very trendy destination among German and international tourists for luxury and shopping. The main purpose of choosing this picture was to contrast modernity with a more traditionally Arab atmosphere. After the participants looked at the picture, they were asked whether they recognize the influencer from social media. Figure 50 shows that $58 \%$ of Brazilian millennials said "NO." German millennials had a $31 \%$ NO response rate. However, $8 \%$ of German millennials responded "YES," which was a higher number than the only $2 \%$ Brazilian millenni als who responded "YES." 


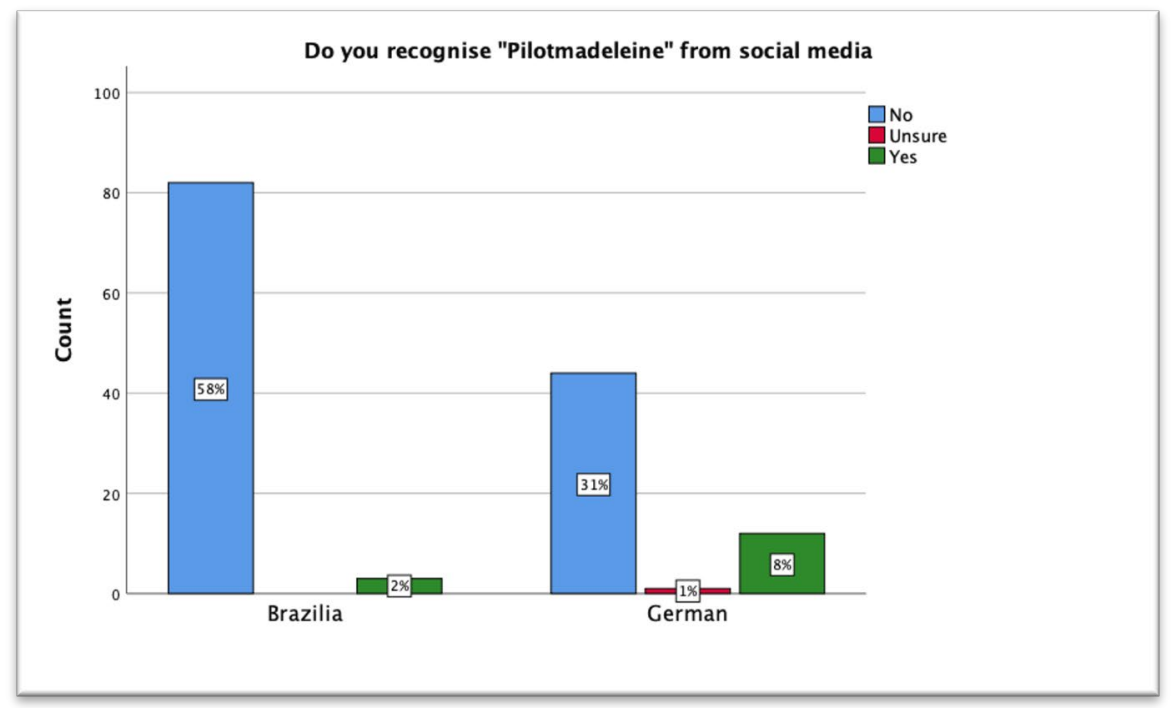

Figure 51: Do you recognize "Pilotmadeline" from social media Source: Own illustration

The author asked the participants after they looked at the picture if the image inspires them to go to Dubai. Figure 51 shows that the majority of German and Brazilian millennials responded "No", with a higher volume of negative responses coming from Brazilians. However, Brazilians has a higher number of "Yes" with 22\% responses compared with the Ger- man millennials with only $10 \%$ responses.

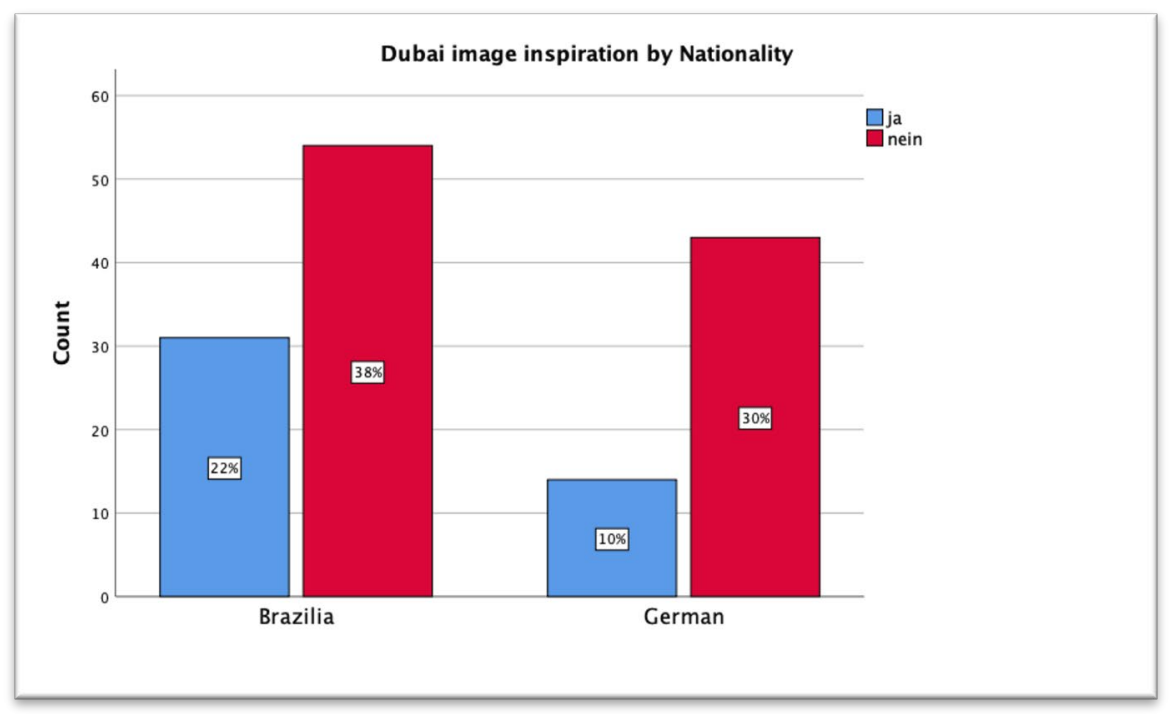

Figure 52: Dubai image inspiration by Nationality Source: Own illustration

The second picture came from the Instagram profile of a Brazilian travel influencer. The author asked the participants if they recognize "Cesaporai" from social media. Figure 52 shows 


\section{S S N $2675-9128$}

that $51 \%$ of the Brazilians and $39 \%$ of Germans responded "NO," with only $7 \%$ of Brazilians and $1 \%$ of Germans responding "Yes".

Figure 53: Do you recognize "Cesarporai" from social media

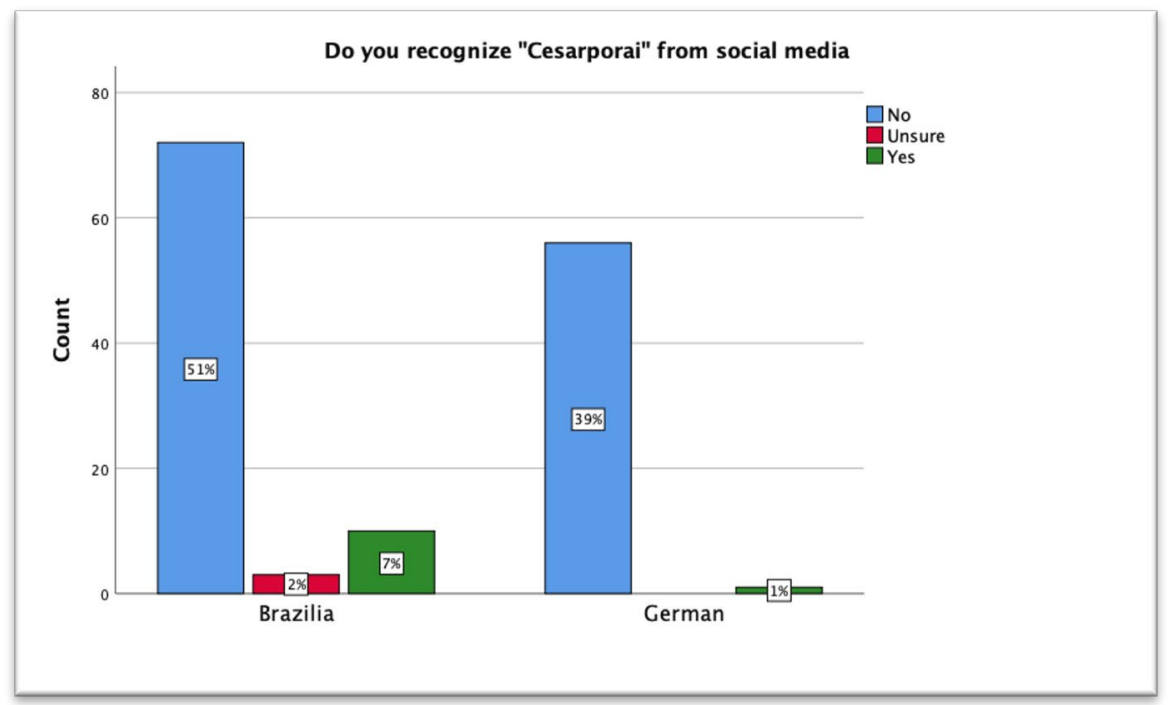

Source: Own illustration

The author wanted to give the participants the feeling of an oriental palace that would give participants the feeling of wanting to get inside and experience its history. Asian countries are currently very trendy among different international tourists, being among the top mostvisited tourist destinations. In addition, studies have shown that German travelers' have increased their international traveling to Asian countries.

After showing the Bagan Palace, the participants where asked if the image inspires them to go there. Figure 53 shows that $40 \%$ of the Brazilian millennials responded "Yes." In contrast, German millennials were less enthusiastic, with 23\% saying "No" and 17\% saying "Yes". 
Figure 54: Bagan Golden Palace image inspiration by Nationality

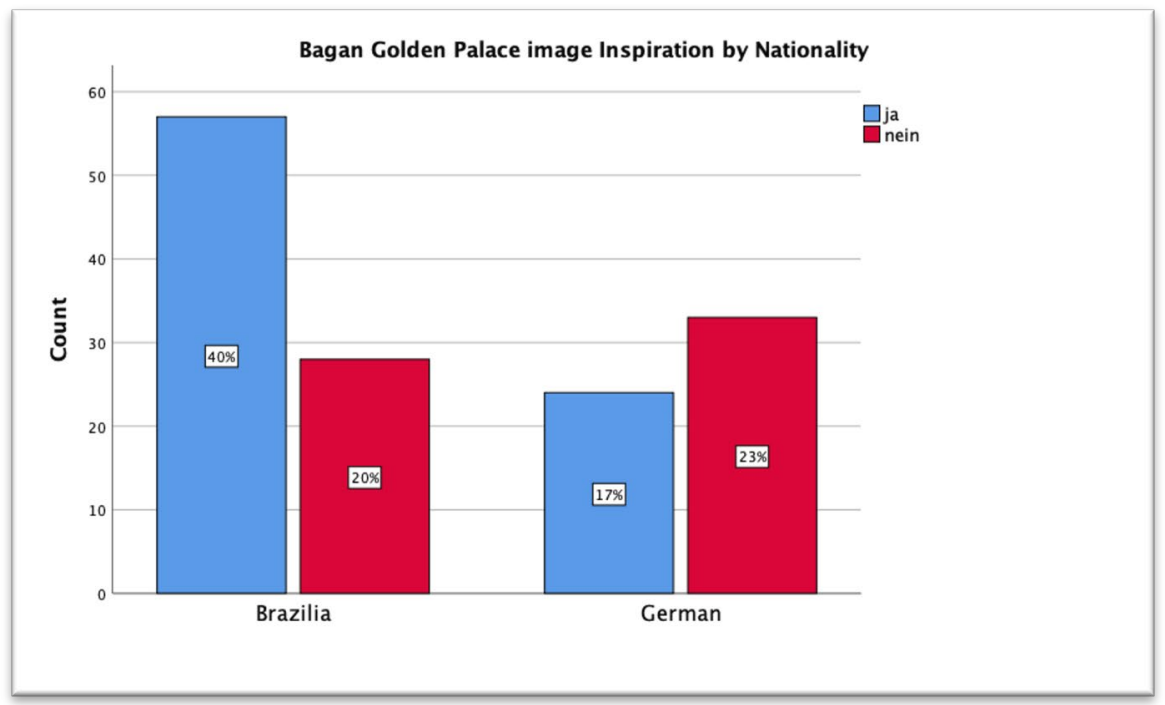

Source: Own illustration

The third picture is taken from a German influencer's social media account. The picture was taken in the Finnish mountains during the wintertime. The author wants to give the participants the feeling of a cozy morning in the winter. This picture was chosen strategically as in Brazil, there is no snow. Therefore, the author wanted to understand if seasonal factors influence Brazilians to choose a destination with snow as it represents a novelty factor of sorts for Brazilians. In addition, German millennials would be expected to show less interest in this image as winter and snow is common in many parts of Germany.

The author asked the participants if they recognize "Yvonnepferrer" from social media. Figure 54 shows that $51 \%$ of Brazilian millennials responded "NO", whereas $32 \%$ of German millennials responded "NO." However, here the exciting finding is that $8 \%$ of Brazilian millennials responded "YES" while 6\% of German millennials responded "Yes". Therefore, one does not necessarily have to be of the same nationality to follow an influencer.

Figure 55: Do you recognize "Yvonnnepferrer" from social media 


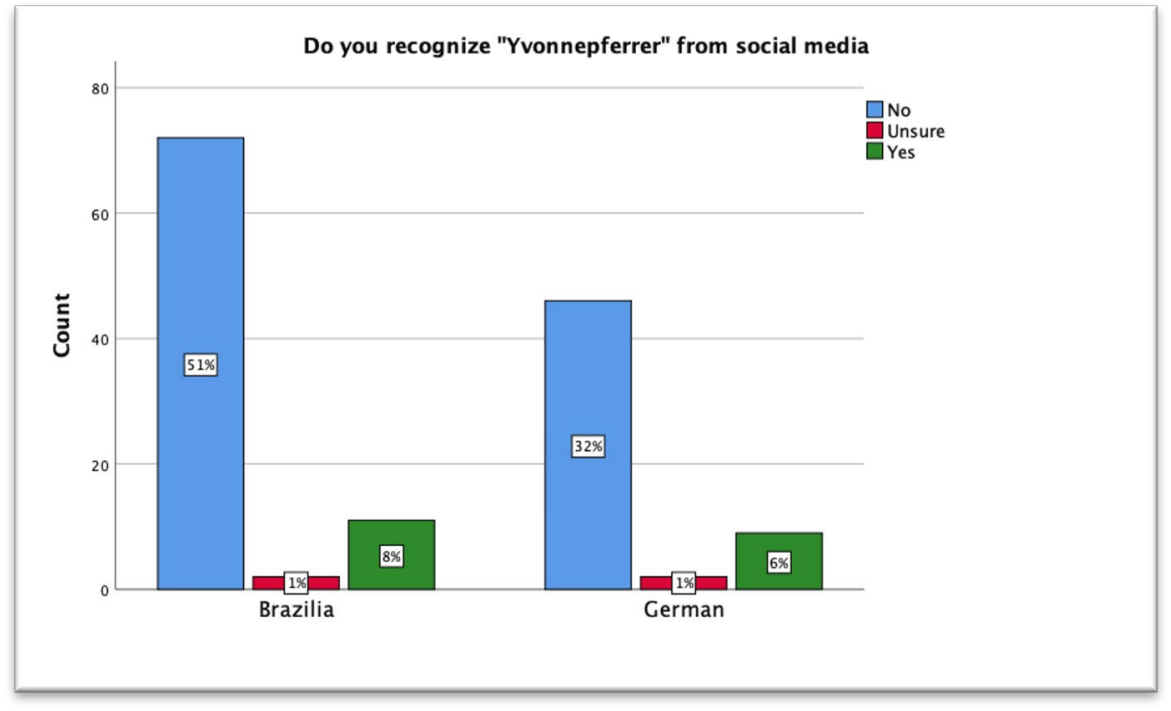

Source: Own illustration

After the author asked the participants if the image inspires them to travel, figure 55 shows that $44 \%$ of Brazilian millennials responded "YES", whereas only $18 \%$ of German millennials responded "YES." Therefore, here it can be assumed that seasonality can play a key role among both German and Brazilian millennials is choosing a travel destination.

Figure 56: Finland image inspiration by Nationality

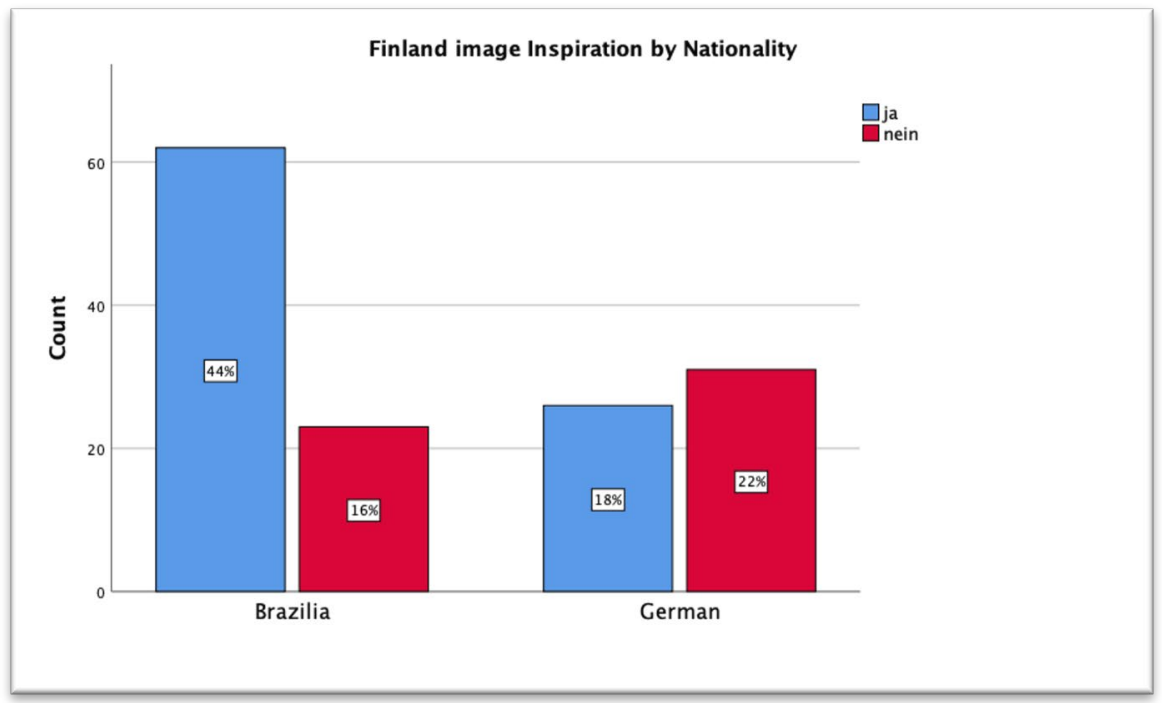

Source: Own illustration

The fourth picture is by a Brazilian influencer. The picture was taken in Nusa Penida, which is very well-known and trendy island in Bali. It is well known for its beautiful beach and RCMOS - Revista Científica Multidisciplinar O Saber. ISSN: 2675-9128. DOI 10.51473 São Paulo, v. 03, p. 01-106, mar. 2021. (cc) BY-NC-SA 


\section{S N $2675-9128$
DOI 10.51473}

diverse places to go out to eat and drink. Moreover, the author wants to give the participants the feeling of jumping in and smelling the salty sea breeze and listing to the waves breaking. This picture was chosen strategically as in Germany there are not many beach places compared to Brazil, which is well-known for its beautiful beaches. Figure 56 shows that $58 \%$ of Brazilian and $31 \%$ of German millennials responded "No", they do not recognize Viajandocomgabi. However, $8 \%$ of the German millennials responded "Yes".

Figure 57: Do you recognize "Viajandocomgabi" from social media

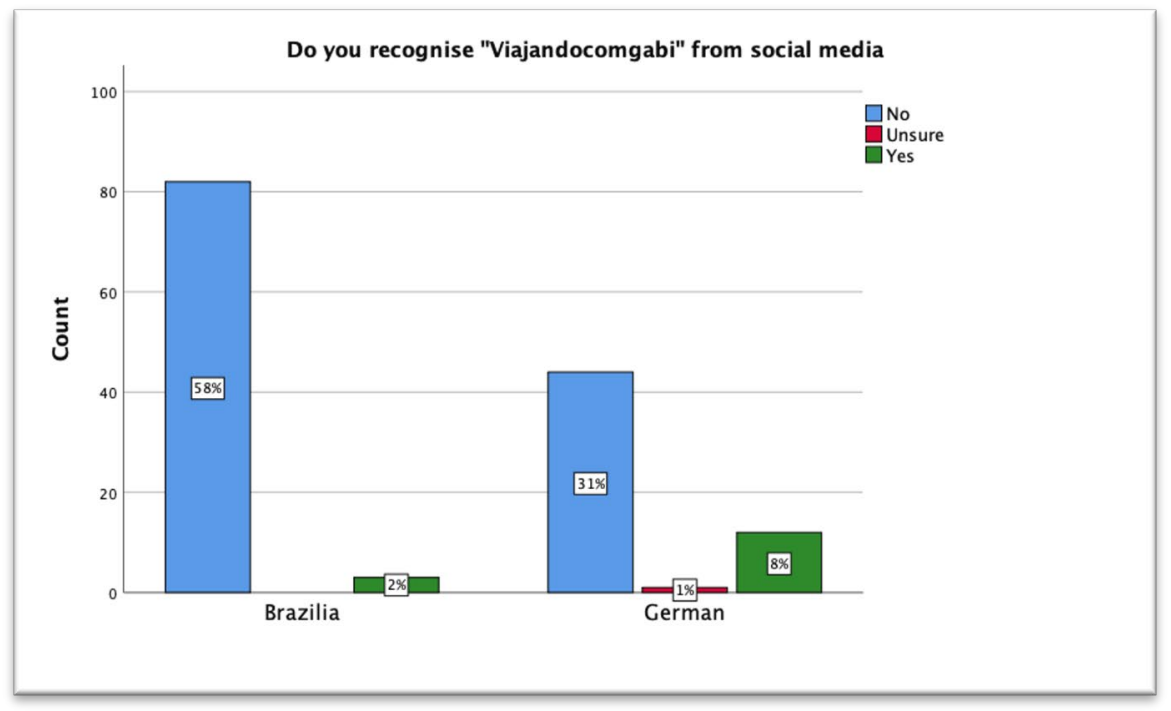

Source: Own illustration

Figure 57 shows that $49 \%$ of Brazilians responded "YES" that the image inspired them to go to Nusa Penida. 29\% of Germans millennials responded "YES." Both Germany and Brazilian millennials had an equal number of responses, saying "NO" (11\%). Therefore, here it can be assumed that both the German and Brazilian millennials are fond of beach locations. 


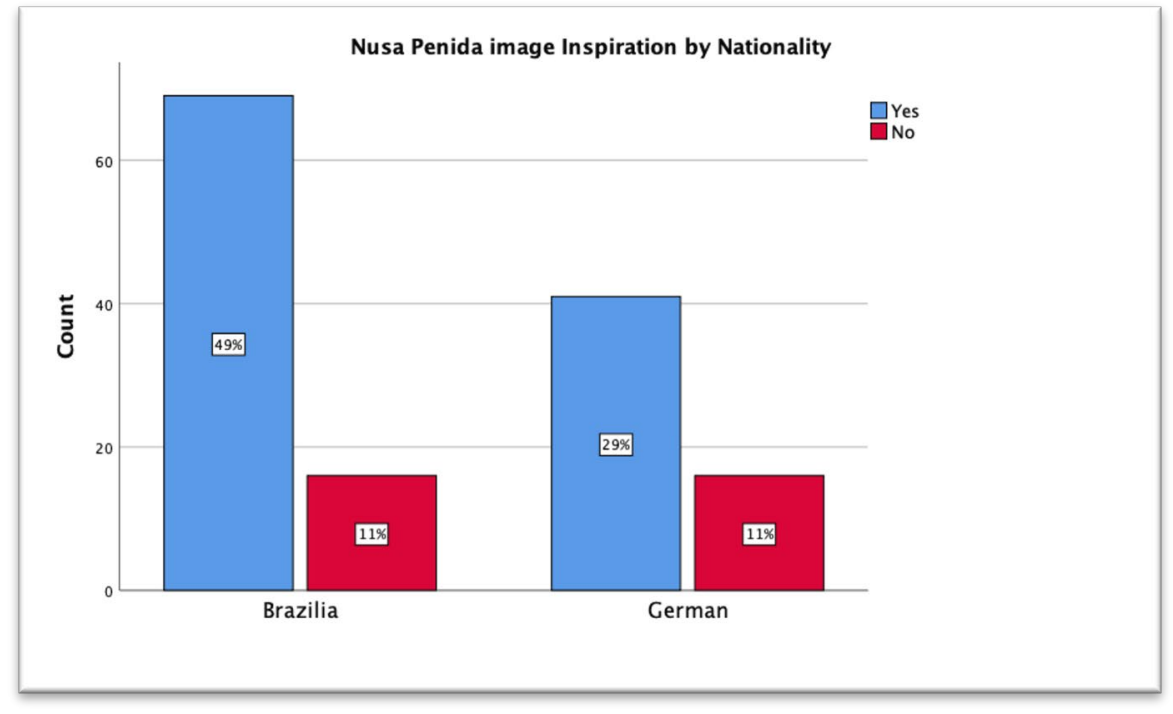

Figure 58: Nusa Penida image inspiration \& Nationality

Findings:

Source: Own illustration

$\diamond \quad$ The majority of Brazilian and German millennials did not recognize the influencers.

$\diamond \quad$ Dubai is more attractive to Brazilian millennials.

$\diamond$ The majority of Brazilian millennials would like to go to Bagan Palace.

$\diamond \quad$ The majority of Brazilian would go to Finland.

$\diamond \quad$ Nusa Penida is the most attractive to German millennials compared with the other destinations.

Overall, in this section it can be inferred that the social media influencer picture posts had a higher impact on Brazilians in terms of convincing them to go to the specific destination compared to the German millennials. Therefore, for the traveller marketer, it is important to optimize the pictures posted of certain destinations to German millennials in order to increase their attention. The highest amount of "Yes" responses among German millennials were on the beach picture in Nusa Penida. It can thus be inferred that German millennials are highly driven by a particular "beach place" feeling. In contrast, Brazilians seem to be attracted to a more varied mix of destination types. 


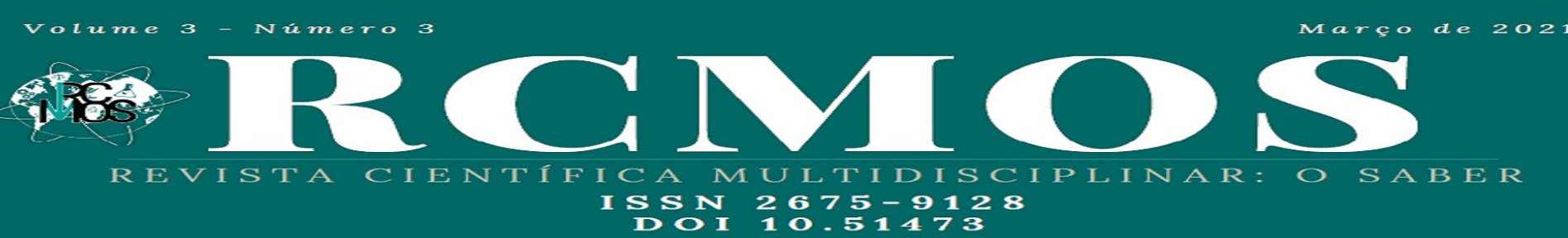

destination choices (Jaya \& Prianthara, 2018). The fact that social media allows users to interact with each other, with influencers and with a specific brand (Hayes \& Carr, 2015) has gained the attention of travel and tourism marketers, who recognize social media's potential as a powerful tool to allow users to directly contribute, collaborate, and interact on travel-related content (Bilgihan \& Barreda, 2015).

Therefore, for the purpose of this master thesis, the author began by reviewing key tourism- related literature. It is essential to acknowledge and understand the importance of tourism in Brazil and Germany. Germany is one of the top spenders in foreign travel, generating approximately 65 billion revenue in a year. (Telegraph, 2017). Furthermore, tourism in Brazil is an important sector for the economy, accounting for 3.1\% of GDP (OECD, 2020). Over the past years, domestic and international tourism has increased among the Brazilians.

Then, the overall characteristics of German and Brazilian millennials were also addressed, with a focus on how these generational groups vary in their travel decision choice. Millennials are people born between the years of 1980 to 2000 (Young \& Hinesly, 2012). Millennials are characterized as being confident, tech-savvy and well-connected. In addition, millennials are becoming a significant growth segment for the international tourism industry (Lončarić \& Dlačić, 2019).

Furthermore, the dissertation addresses influencer marketing and how information gathering and evaluation have become an essential part of tourists choosing a destination (Karamehmedović, 2019). Social media has revolutionized many business and marketing strategies by improving customer information access and sharing when compared to traditional marketing techniques (Song, 2016). Studies have shown that providing a more inter- active experience leads to higher customer satisfaction with the service and brand. Social media gives users, particularly millennials, a chance of self-expression.

Moreover, the author engaged with the consumer behavior literature in regards to its application to the tourism context. It is essential for tourism managers and marketers to understand the different motivational factors involving travel decisions, the importance of attitudes, and the influence of reference groups on an individual's travel decision-making. The consumer buying process was defined and explained to promote an understanding of the purchase decision-making process. Moreover, the Theory of Planned Behavior (TPB) was applied to the tourism context in order to engage with the many challenges and factors that determine destination choice. Tourists have become one of the main decisive factors for any tourism 


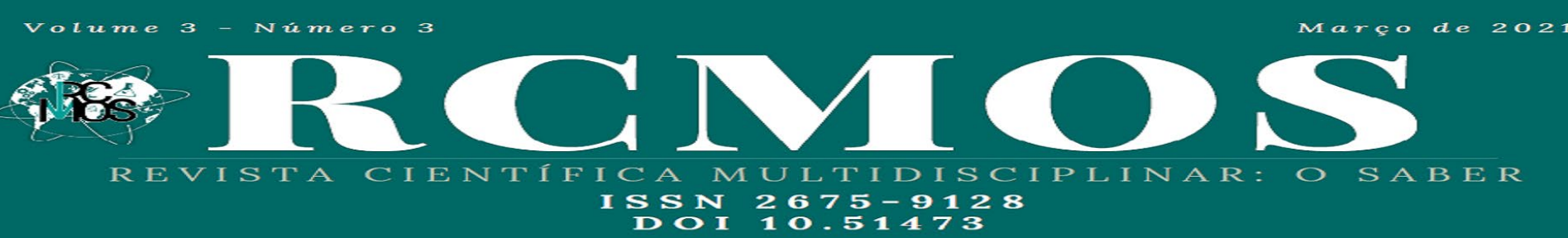

industry (Ziadat, 2015). Therefore, it was crucial for the author to gain information about tourist behavior and their expectations and desires when choosing a destination.

The theory of planned behavior (TPB) model was applied to help predict the behavioral intention of destination travel choice throughout attitudes, subject norms, and perceived behavioral control. The TPB model suggests that individuals are more likely to behave in a certain way if they believe that behavior to be conducive to the creation of a self-image and a conclusion by their community/ reference group that is valuable for them as a significant importance (Quintal \& Lee, 2010). Within the attitude element, the initial destination evaluation can be crucial in terms of manifesting a potential intention to visit a particular destination. In this sense, the individual's initial attitudes about a certain destination will depend on the significant importance that they assign to going to that destination It is presumed that the attitudes about choosing a destination will depend on the significant importance of a particular destination.

A second and equally important concept of the TPB is the subject norm. The subject norm is the subjective perception of an individual on the cultural references, beliefs or judgments by their reference group they turn to for judgement on whether they should or should not perform a specific behavior. When the individual acts on these perceived judgements by their family, friends, and broader social circle, the intention to travel can materialize.

Social media provides an avenue for users to engage in the sort of "behavioral modulation" encompassed by the subjective norm. When people post on social media, they do so in part to gain attention and acceptance from their social circle. When they post something, they expect to get either a like or comment under their post. This gives the individual an expectation and a "measurable" benchmark of what others think of him or her. While performing certain acts to be accepted within one's social group has been observed in many societies across history, social media has provided individuals with a vehicle to share many more aspects of their lives, including travel experiences. The availability of such a vehicle can also be argued to have increased this need to share and know what others are doing in their lives.

After reviewing the secondary literature, primary data was collected from an online questionnaire. Of the 231 participants who responded to the survey, 196 completed it. However, 35 participants did not finish answering the questionnaire. In total, 85 were Brazilian, 57 were German, and 54 were from other countries.

6.1 Key Findings from the online survey 
$\diamond$ The majority of participants have social media accounts.

$\diamond$ Instagram is the favorite social media app of Brazilian and German millennials prefer and spend more time on.

$\diamond$ Family and friends are the preferred source for information on travel destinations, with social media coming in second.

$\diamond$ The most important attractions among Brazilian and German millennials are beach and culture in general.

$\diamond \mathrm{Bad}$ weather acts as the major deterrent to choosing a potential travel destination for both Germans (32 responses) and Brazilians (31 responses).

$\diamond$ While a significant portion of Brazilians reported price/exchange rate pressures as being relevant impediments to choosing a given travel destination (55 responses), Germans are not as bothered by these prospects, with only 8 selecting this response.

$\diamond$ Security is a more significant factor for Germans not to choose a destination compared to Brazilians. 51 German responders indicated this was an issue compared to 38 Brazilian responders.

$\diamond$ Brazilians tend to choose "I am active and post regularly" more frequently com-pared to German millennials.

$\diamond$ German millennials score higher in "I am a silent observer and never post."

$\diamond$ The majority of German and Brazilian millennials view travel influencers "sometimes."

$\diamond$ The majority of Brazilian and German millennials "sometimes" post their travel pictures on social media.

$\diamond$ The majority of Brazilian and German millennials like both short and long trips.

$\diamond$ The majority of Brazilian and German millennials did not recognize the influencers.

$\diamond$ Brazilians are more likely to want to go to Dubai

$\diamond$ The majority of the Brazilian millennials would like to go to Bagan Palace.

$\diamond$ The majority of Brazilian would go to Finland.

$\diamond$ Nusa Penida attracted German millennials the most compared to other destinations.

Before discussing gender differences in social media consumption, it is important to note that the vast majority of survey respondents were female Brazilian millennials. There is a general overrepresentation of women among both nationality groups. Data gathered from the online questionnaire showed that females spend more time on Instagram than males, whereas, 
males spend the most time on Facebook and YouTube compared to females. Therefore, males and females are more likely to search for products and services through different social media channels. Considering the existing literature on differences in consumption based on gender, female and male consumers can be said to have different priorities. For the purpose of this study, it can be argued that destination choice will vary de- pending on how the priorities of travelers and the qualities of that particular destination offers. The majority of the Brazilian and German millennials have social media. Instagram is the preferred social media app among participant millennials regardless of gender or nationality.

Friends and family account for the most content viewed on social media by participant millennials. In addition, most millennials tend to turn to friends and family regardless of nationality and gender, with social media search coming in second. However, it is interesting to note that, in comparison with German millennials, Brazilian millennials preferred to consult a travel agency for tourism information at much higher rates. In addition, Brazilian millennials also use television and series as sources for travelling information at higher rates. Therefore, the subjective norm of the TPB model provides most relevant insights here, considering that the theory finds that individuals seek to emulate behaviour they believe to be approved by the reference group. When pieced together, the three findings of the survey demonstrate that interactions with their social circle through social media is important for millennials. The fact that they turn to their reference groups and to social media in order to get travel information corroborates 1) The existence of the approval-seeking mechanism behind millennials' destination choices and intentions to travel and 2) The relevance of social media as a marketing tool for tourism managers to target millennials effectively. These findings can also indicate that millennials think that travel recommendations by friends and family will be safer and lead to less judgements from their social circles.

To assess the main motives for choosing a travel destination, participants were asked about which attractions and qualities motivate them to choose or not choose a given travel destination. The survey findings show that culture, history, and sighting are the most important factors to motivate millennials to make a travel decision, with beach and water sports coming in second. Despite many commonalities, Germans and Brazilians also differ in terms of a few specific interests: German millennials prioritize beach and sport, whereas Brazilian millennials rank theme parks and shopping higher. In addition, for Brazilian millennials, culture and cuisine are the second-highest attractions. Brazilians and Germans also differ in terms of the barriers to travel that they identify as being the most significant. While Brazilians are more affected by 


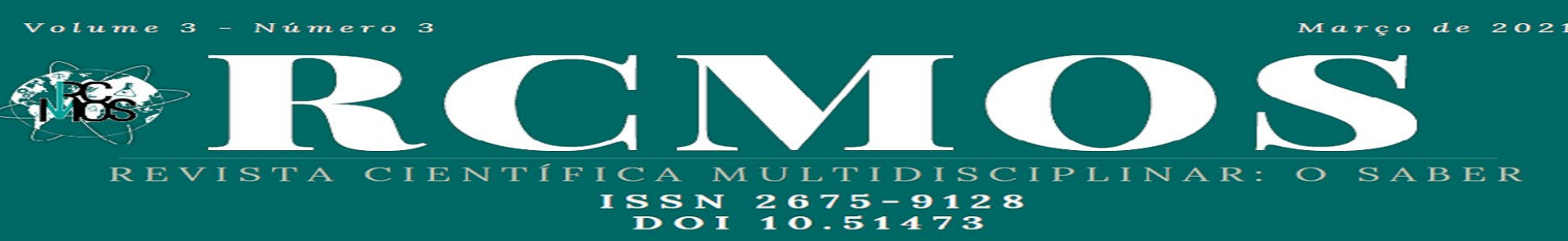

price and currency ex- change rates, German millennials identify security and bad weather as primary impediments. Here, the perceived behavioural control aspect of the TPB model allows us to interpret these findings in a more sophisticated way. Perceived behavioral control is the belief by tourists about the extent to which they have control over the barriers to travel that they have identified as impediments to destination choice. If individuals perceive themselves as having little to no behavioral control about these impeding factors, this will ultimately override individual motivation or societal pressure to travel to a certain destination. If, for instance, millennials do not have the time or the financial resources to travel, it will be harder for such behavior to occur. Thus, marketing managers to be aware of the primary barriers to travel by millennials and need to devise strategies to demonstrate that they have high behavioral control in relation to these barriers.

On the social media habits among millennials, both groups report to be engaged but rarely post. However, Brazilians appear to be more active and post more regularly compared to Germans, who identified themselves as being "silent observers" in higher numbers. The majority of the Brazilian "always" post their travel pictures compared to German millennials who only post "sometimes". It could be argued that Brazilian millennials are more affected by the subjective norm element of the TPB model as they post more about their travel experiences to garner engagement and approval from their social circle. Therefore, more positive feedback on their travel experience can be expected to result in higher intention to travel among Brazilians. The main importance of why Brazilian uses social media is to keep in touch with friends, and the least important is to promote products. Moreover, while the majority of Brazilian and German millennials like both short and long trips, more Brazilians prefer shorter trips over longer trips and more Germans millennials prefer longer trips over short trips.

Germans and Brazilians report some commonalities in how trustworthy they find influencers: While both tend to broadly agree that influencers are trustworthy, make valuable travel recommendations, draw attention to new products, inspire to travel and help viewers to choose a destination, there are also notable differences. Brazilian millennials have a strongly in agree compared with the German millennials. In addition, both agreed that seeing travel influencers experiences on social media impact on their opinion about the travel destination.

For the purpose of this master study, pictures were essential elements to understand the main impact of influencer marketing among Brazilian and German millennials. After showing four different image posts by influencers, Brazilian millennials were found to be more likely than German millennials to want to travel to destinations depicted in the posts. The fact that 


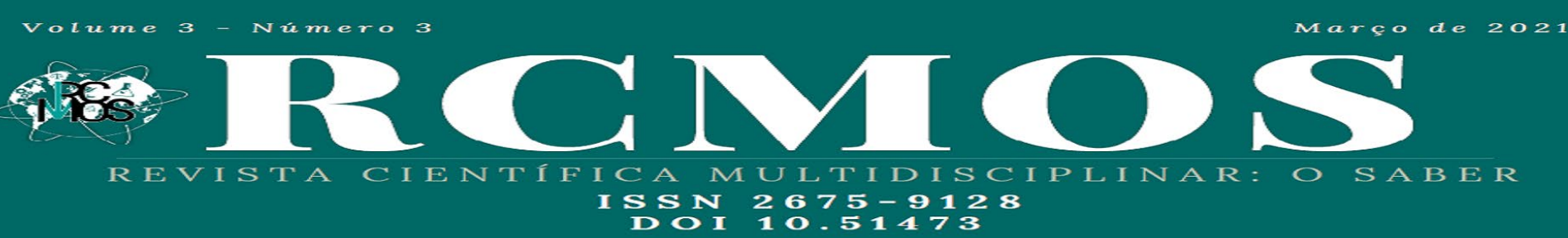

Nusa Penida, a beach destination, generated most interest among German millennials corroborates earlier findings about the popularity of beach destinations among Ger- man millennials. In contrast, Brazilians appeared to be attracted to a more mixed set of destination types.

\subsection{Recommendations to travel marketers}

The online surveys conducted as part of this Master's thesis have proven that Brazilian and German millennials are more influenced by travel recommendations throughout their family and friends, followed by social media. Therefore, marketers have a higher chance to attract their target group to a destination by optimizing the way social media influencers interact with followers. This could be done by encouraging influencers to increase posting volume and encourage followers to repost pictures so that their friends and family can see influencer content. Tourism marketers and influencers should also encourage higher engagement through user-generated content. This can be done by influencers motivating followers to post/ repost their own travel pictures, ask them about their experiences and preferences.

It would be positive in general if influencers, marketers and tourism managers found ways to engage users' friends and family in their influencer marketing strategies (Wiley, 2019). In this sense, it would be positive to get tourists to post more on their social media about their travel experiences generally, as this will increase the probability of engagement and positive feedback by friends and family, motivating them to travel again soon. In addition, a user's travel-related content is also likely to motivate people within his/her social circle to travel as people can be both recipients and "enforcers" of the subjective norm. Apart from the aforementioned reasons, encouraging German and Brazilian millennials to share images, videos, and stories online can also give marketers a better overview of what German and Brazilian millennials are experiencing and want out of their travels.

Germans' millennials are more reserved when sharing their travel experience on social media, travel marketers should find ways to motivate German millennials when choosing a travel destination. Being aware of the barriers Germans and Brazilians perceive as preventing them from choosing a destination is an important part of this process. Brazilian millennials are more affected by the exchange rate and are more price sensitive. Thus, marketers should attract Brazilian millennials at least partly based on the price. On the other hand, German millennials find security to be a main factor that prevents them from choosing a travel destination. Thus, marketers should target safer destinations to German millennials and emphasize the security 


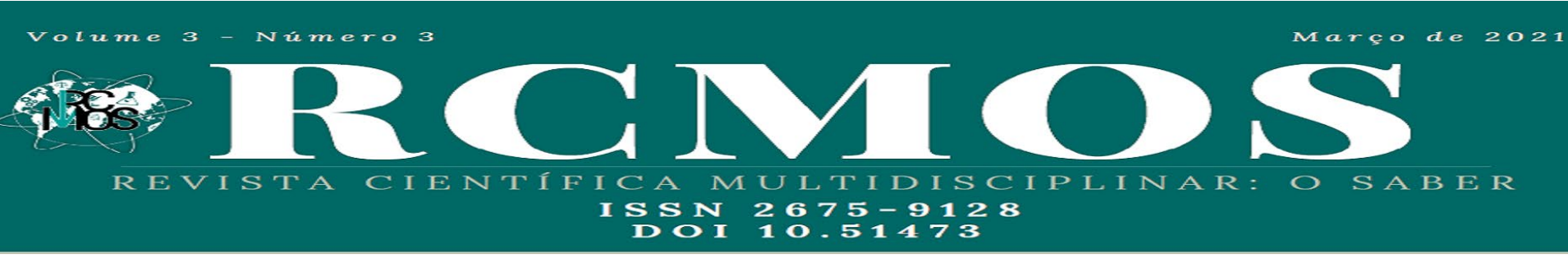

aspect in their communications. Considering that visual content tends to generate more engagement on social media, every hotspot location could have a big camera which the traveller could take a photo with next to a landmark/ nice landscape and post it directly to social media. It is essential to consider that Brazilian are more influenced by picture posts than German millennials. In addition, gender difference highlighted in the survey, such as female preferences for Instagram and male preferences for YouTube, should also be taken into consideration by travel marketers. Therefore, marketers have to optimize their targeted tourism communication strategies ac- cording to nationality and gender preferences.

\subsection{Contribution to theory}

The key results of this master thesis contribute to the subjective norm theoretical framework from the TPB theory by providing insights about how Brazilian and German millennials share and interact on social media. The primary data collection provided evidence on millennials' relationships with social media and the emotional and psychological importance of their social circles when determining travel intention and destination choice. This information can be used when attempting to target millennials more generally and Brazilian and German millennials more specifically. It is thus vital that travel marketers emphasize usergenerated content and information sharing through social media in order to harness millennials' trust in social media and their reliance on friends and family for destination choice.

Moreover, this study also adds further evidence to the perceived behavioral control literature. As primary data collection asks millennials about factors that would prevent them from choosing a destination and about the more systemic barriers to travel, this study provides additional insight on which control beliefs are most important to German and Brazilian millennials. For example, Brazilian millennials find that the exchange rate plays a key role for not choosing a travel destination as is "too expensive" for them. Therefore, the extent to which Brazilians believe to have the necessary financial resources to travel acts as a control belief that can prevent travel. A similar phenomenon occurs with Germans when it comes to security. Thus, this study adds information about cross-country variations in perceived behavioral control, allowing marketers to devise more sophisticated marketing strategies for the many segments in the tourism market.

\subsection{Limitation}


millennials' travel destination choices. The research provides evidence that friends, family, and social media have a direct influence and play a decisive role in millennials' travel decision making. Furthermore, there are gendered preferences when it comes to type of social media platform. Moreover, this study topic has the possibility to be further developed by exploring variation in the primary purpose of social media use.

Overall, the recommendations of friends and family and social media have a greatly impact on millennial travel destination choice. Still, further research needs to be done about the complex reason's millennials turn to their social circle and the internet for advice. While influencer marketing has been found to be largely effective on millennials, the reasons why influencers are engaged with and trusted when it comes to destination choice need to be explored further. In addition, further research on which gender looks for what kind of travel information on what kind of social media is needed. In addition, it would be interesting to uncover whether family or friends are more significant predictors of destination choice among Brazilians and Germans and males and females. Lastly, while Brazilians were more influenced by picture posts than Germans, it would be interesting to discover whether such differences also occur when the type of visual media changes. 


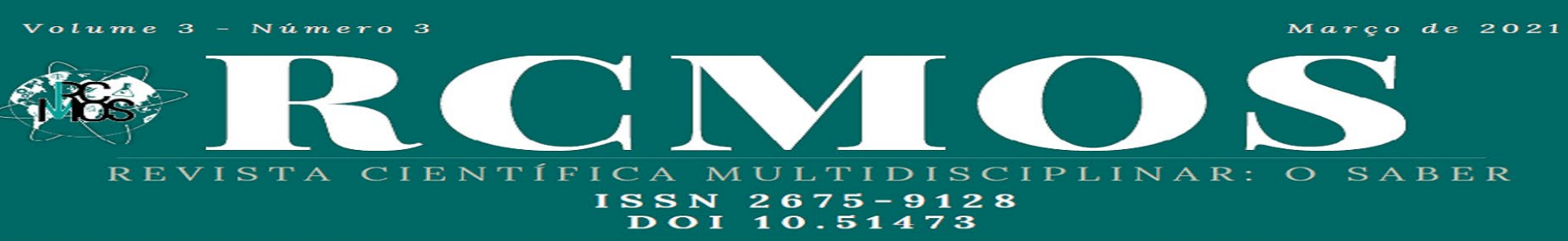

Chaffey, D. (2016). Digital Marketing. Ann Arbor.

Chapman, S., \& McNeill, P. (2005). Research Methods. Routledge.

Chen, J., \& Huang, Y. (2009). Vacation lifestyle and travel behaviors. Journal of travel and tourism marketing, 494-506.

Cheung, C., \& Rabjohn, M. (2008). The impact of electronic word-of-mouth the adoption of online opinions in online customer communities. Internet Research, 229-247.

Clement , J. (02. 07 2020). Statista. Von Snapchat- Statistics \& Facts : https://www.statista.com/topics/2882/snapchat/ abgerufen

Clement , J. (08. 03 2020). Statista . Von YouTube - Statistics \& Facts: https://www.statista.com/topics/2019/youtube/ abgerufen

Clement, J. (14. 02 2020). Statista. Von Global social networks ranked by number of users 2020 Published by J. Clement, Feb 14, 2020 This statistic provides information on the most popular networks worldwide as of January 2020, ranked by number of active accounts. Market leader Facebook was the: https://www.statista.com/statistics/272014/global-socialnetworks-ranked-by- number-of-users/ abgerufen

Clow, K., \& James, K. (2014). Essentials of marketing research putting research into practice. Los Angeles: SAGE Publications, Inc.

Darley, W., \& Blankson, C. (2010). Toward an Integrated Framework for Online Consumer Behavior and Decision-Making Process: A Review. Psychology \& Marketing, 94- 116.

Daugherty, T., \& Eastin, M. (2008). Exploring Consumer Motivations for Creating UserGenerated Content. Journal of Interactive advertising, 16-25.

Destatis. (10. 02 2010). Tourism in Germany 2019: number of overnights at new record high for the 10th successive year. Von Destatis Statistichs Bundesamt: https://www.destatis.de/EN/Press/2020/02/PE20_041_45412.html abgerufen

Diario do Turismo. (14. 08 2018). Diario do Tourismo. Von Novelas brasileiras impulsionam o turismo: https://diariodoturismo.com.br/novelas-brasileiras- impulsionam-o-turismo/ abgerufen

Dinner, E., \& Crandall, R. (1978). Ethics in social and behavioral research. Universty Chicago Press.

Dogru, T., \& Bulut, U. (2018). Is tourism an engine for economic recovery? Theory and empirical evidence. Tourism Management, 425-434.

Fallon, M. (2016). Writting up Quantitative Research in the social and behavioural sciences . Rotterdam: Sense Publishers. 


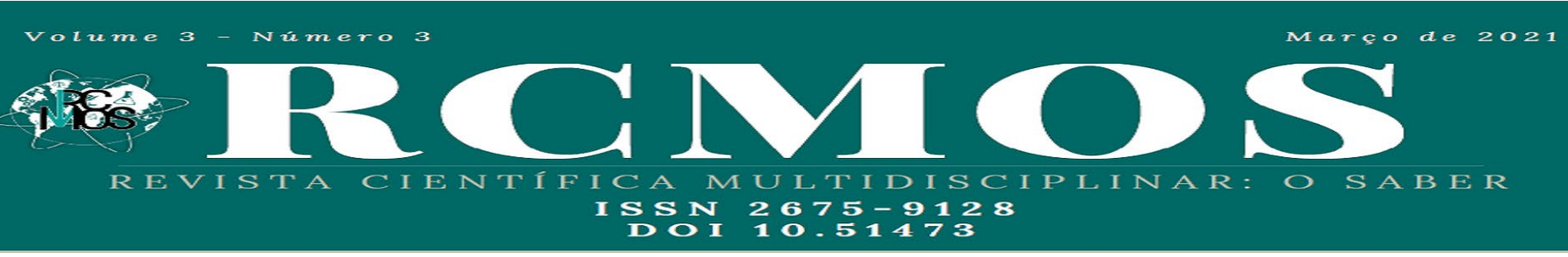

Jakopović, H. (2015). YouTube's Role in Destination Image Creation. Journal of Education Culture and Society, 217-226.

Jalilvand, M., \& Samiei, N. (2012). The impact of electronic word of mouth on a tourism destination choice Testing the theory of planned behavior (TPB). Internet Research, 591-612.

Jaya, P., \& Prianthara, I. (2018). Role of Social Media Influencers in Tourism Destination Image: How Does Digital Marketing Affect Purchase Intention? Advances in Social Science, $1-20$.

Jordan, E., \& Boley, B. (2018). Predictors of intention to travel to Cuba across Three times horizons: An Application of the theory of planned behavior. Empirical Research Article, 981993.

Juschten, M., \& Pürrer, A. (2019). The mountains are calling! An extended TPB model for understanding $\mathrm{T}$ metropolitan residents' intentions to visit nearby alpine destinations in summer. Tourism Management, 293-306.

Karamehmedović, D. (2019). Cultural tourists and the source of information. Department of Tourism, 87-105.

Koptyug, E. (19. 12 2019). requency of using social media (e.g., facebook, twitter, instagram, whatsapp) among millennials in Germany in 2019. Von Statista:

https://www.statista.com/statistics/790986/social-media-usage-frequency-among- millennialsgermany/ abgerufen

Koptyug, E. (12. 03 2019). Frequency of using the internet among millennials in Germany in2018, compared to the population. Von Statista:

https:/www.statista.com/statistics/977397/using-internet-frequency-millennials- germany/ abgerufen

Kotler, P., \& Gary, A. (2016). Principles of Marketing. Person Education.

Lam, T., \& Hsu, C. (2006). Predicting behavioral intention of choosing a travel destination. Tourism Management, 589-599.

Lee, S., \& Jang, W. (2016). Search engine optimization A case study using the bibliographies of LG Science land in Korea. Library High Tech, 197-206.

Lim, X., \& Wong, M. (2011). The impact of social media influencers on purchase intention and the mediation effect of customer attitude. Asian Journal of Business, 19-36.

Lincoln, Y., \& Guba, E. (1985). Naturalistic Inquiry. SAGE Publications.

Liu, H., \& Wu, L. (2019). Social media envy: How experience sharing on social networking sites drives millennials aspirational tourims consumption. Journal of travel research, 355369. 


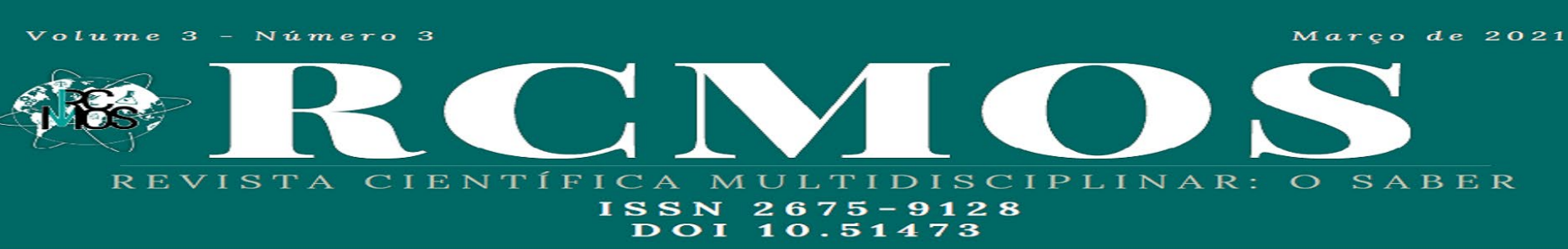

Lončarić, D., \& Dlačić, J. (2019). Attracting young travellers to a tourist destination: Exploring millennials dremas. Tourims in Southern and Eastern Europe, 405-417.

MacGeorge, E., \& Swol, L. (2018). The oxford handbook of Advice. Oxford University Press.

Martin, D., Ramamonjiarivelo, Z., \& Martin, W. (2011). MEDTOUR: a scale for measuring medical tourism intentions. Tourism Review, 45-56.

Masiero, L., \& Qiu, R. (2018). Modeling reference experience in destination choice. Annals of Tourism Research, 58-74.

Mathew, J. (30. 07 2018). Understanding Influencer Marketing and Why It Is So Effective. Von Forbes: https://www.forbes.com/sites/theyec/2018/07/30/understanding- influencermarketing-and-why-it-is-so-effective/\#198d785971a9 abgerufen

McKeown, R., \& Weed, D. (2004). Ethical choices in survey research. Hinks \& Kinks in sruvery research, 67-68.

Middleton, V., \& Fyall, A. (2009). Marketing in Travel and Tourism. Elsevier. Morgan, N., \& Pritchard, A. (2008). Advertising in tourism and leisure. Ann Arbor.

Murray, S., \& Ambrose, R. (2006). Monitoring rocky shores. Los Angeles: University of California Press.

Narangajavana, Y., \& Fiol, L. (2017). The influence of social media in creating expectations. An empirical study for a tourist destination. Annals of Tourims Research, 60-70.

OECD. (04. 03 2020). OECD. Von OECD Tourism Trends and Policies 2020:

https://www.oecd-ilibrary.org/sites/6b47b985en/1/2/5/1/index.html?itemId=/content/publication/6b47b985-

en\&_csp_=a806bfa96e09b9351b58695070b6c960\&itemIGO=oecd\&itemContent $\mathrm{T}$ ype=book abgerufen

OECD. (04. 03 2020). OECD. Von OECD Tourism trends and policies 2020:

https://www.oecd-ilibrary.org/sites/6b47b985-

en/1/2/4/11/index.html?itemId=/content/publication/6b47b985-

en\&_csp_=a806bfa96e09b9351b58695070b6c960\&itemIGO=oecd\&itemContent $\mathrm{T}$ ype=book abgerufen

OECD. (11. 04 2020). OECD Data. Von Germany: https://data.oecd.org/germany.htm abgerufen

OECD. (29. 03 2020). Outbound Tourims. Von OECD: https://stats.oecd.org/Index.aspx?DataSetCode=TOURISM_OUTBOUND abgerufen

Ortíz, J., \& Corrada, M. (2019). Millennials \& Snapchat: Self-expression through its use and its influence on purchase motivation. Jorrnal of Business Research, 1-8. 


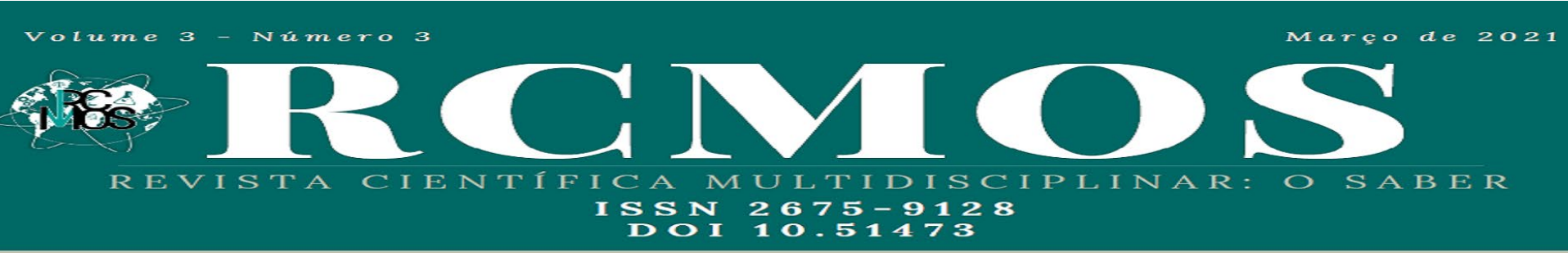

Pasquali, M. (06. 02 2019). Statista. Von Minimum monthly wage in Brazil from 2000 to 2019: https:/www.statista.com/statistics/949779/evolution-minimum-wage-brazil/ abgerufen

Pfund, C. (17. 12 2019). The Pros and Cons of Influencer Marketing for Your Brand. Von Forbes: https:/www.forbes.com/sites/theyec/2019/12/17/the-pros-and-cons-of- influencermarketing-for-your-brand/\#41581f075ed0 abgerufen

Prasad, R., \& Jha, M. (2014). Consumer bying decision models: A descriptive study. International Journal of Innovation and Applief Studies, 335-351.

Pratt, S., \& Sum, W. (2016). Destination Image and Intention to Visit the Tokyo 2020 Olympics among Hong Kong Generation Y. Journal of China tourism research, 355-373.

Pwlik, V. (24. 01 2019). Statista. Von Millennials in Deutschland nach Netto-Einkommen im Vergleich mit der Bevölkerung im Jahr 2018:

https://de.statista.com/statistik/daten/studie/713078/umfrage/umfrage-in- deutschland-zumnetto-einkommen-der-millennials/ abgerufen

Quintal, V., \& Lee, J. (2010). Risk, uncertainty and the theory of planned behavior: A tourism example. Tourism Management, 797-805.

Ravald, A., \& Grönroos, C. (1996). The value concept and relationship marketing. European Journal of Marketing, 1-19.

Rudnicka, J. (03. 03 2020). Statista. Von Höhe des durchschnittlichen Bruttolohns/ Bruttogehalts im Monat je Arbeitnehmer in Deutschland von 1991 bis 2019:

https://de.statista.com/statistik/daten/studie/161355/umfrage/monatliche- bruttoloehne-undbruttogehaelter-pro-kopf-in-deutschland/ abgerufen

Saraniemi, S., \& Kylänen, M. (2011). Problematizing the CProblematizing the concept of Tourism Destination: An Analysis of Different Theoretical Approaches. Journal of Travel Research, 133-143.

Saunders, M., Lewis, P., \& Thornhil, A. (2015). Research methods for business students. Pearson Education.

Sethna, Z., \& Blythe, J. (2016). Consumer Behaviour. Sage.

Sharon, N., \& Angely, L. (2015). Handbook of culture and consumer behaviour. Oxford.

Shavitt, S., \& Cho, H. (2016). Culture and consumer behaviour: the role of horizontal and vertical cultural factors. Current Opinion in Psychology, 149-154.

Shirisha, M. (2018). Digital Marketing Importance in the new era. International journal of engineering technology science and research, 612-617.

Soliman, M. (2019). Extending the Theory of Planned Behavior to Predict Tourism Destination Revisit Intention. International Journal of Hospitality \& Tourism Administration, $1-26$. 


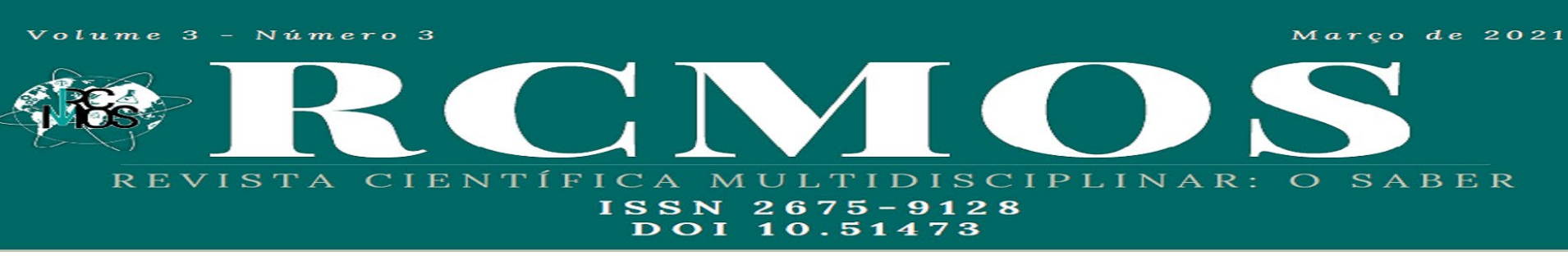

Song, S. (2016). The role of social media during the pre-purchasing stage. Journal of Hospitality and Tourism Technology, 84-99.

Sparks, B., \& Pan, G. (2009). Chinese Outbound tourists: Understanding their attitudes, constraints and use of information sources. Tourism Management, 483-494.

Statista. (13. 02 2020). International overnight visitors in the most popular city destinations worldwide 2018 Published by S. Lock, Feb 13, 2020 Bangkok had the most international overnight visitors in 2018 with 22.78 million, followed by Paris and London with 19.1 and $19.09 \mathrm{mi}$. Von Tourism \& Hospitality: https://www.statista.com/statistics/310355/overnightvisitors-to-top-city- destinations-worldwide/ abgerufen

Statista. (18. 10 2019). Millennials in Germany 2018, by type of vacation trips Published by Evgeniya Koptyug, Oct 18, 2019 This statistic shows the type of vacation trips undertaken by German millennials in 2018. That year, among millennials ages 18 to 25 years, almost 47 perce. Von Statista: https://www.statista.com/statistics/977617/millennials-by-type-vacationtrips- germany/ abgerufen

Statista. (08. 042019 (d)). Value of international expenditure by travelers from Latin America and the Caribbean in 2017, by country. Von Statista:

https://www.statista.com/statistics/909379/outbound-tourist-expenditure-latin- americacountry/ abgerufen

Statista. (09. $082019(\mathrm{k}))$. Advertising \& Marketing. Von Leading benefits of using social media for marketing purposes worldwide as of January 2019:

https://www.statista.com/statistics/188447/influence-of-global-social-media- marketingusage-on-businesses/ abgerufen

Statista. (10. 112019 (f)). Latin American and Caribbean countries with the largest number of international tourist arrivals in 2018. Von Statista:

https://www.statista.com/statistics/305482/latin-american-countries-with-the-mostinternational-tourist-arrivals/ abgerufen

Statista. (11. 032019 (1)). Distribution of social media users in Brazil in 2019, by age. Von Statista: https://www.statista.com/statistics/468122/age-distribution-of-social- media-usersbrazil/abgerufen

Statista. (12. 082018 (e)). European countries with the largest number of international tourist arrivals in 2018 Published by S. Lock, Oct 8, 2019 This statistic shows the European countries with the largest number of international tourist arrivals in 2018. France was the. Von Statista: https://www.statista.com/statistics/261729/countries- in-europe-ranked-byinternational-tourist-arrivals/ abgerufen

Statista. (14. 082019 (a)). Social media \& user generated content. Von Number of social network users worldwide from 2010 to 2021 (in billions):

https://www.statista.com/statistics/278414/number-of-worldwide-social-network- users/ abgerufen 


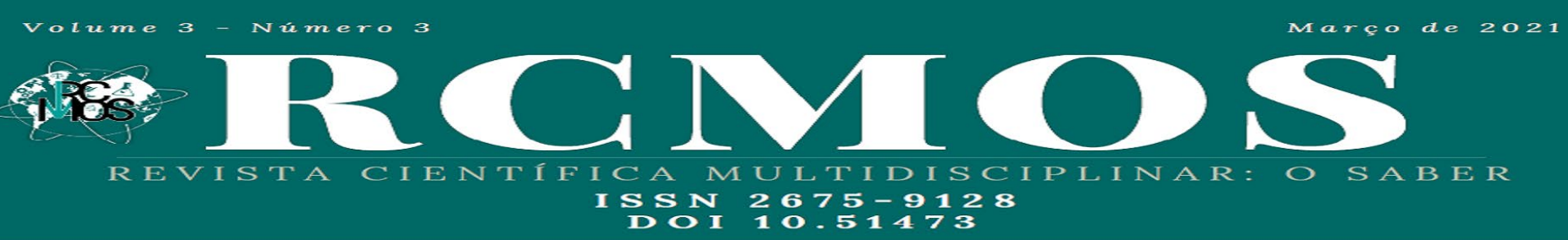

Statista. (14. 082019 (i)). Social media \& user generated content. Von Number of social network users worldwide from 2010 to 2021 (in billions):

https://www.statista.com/statistics/278414/number-of-worldwide-social-network- users/ abgerufen

Statista. (15. 102019 (c)). Number of outbound overnight trips in the European Union (27 countries) in 2018, by country. Von Leisure Travel:

https://www.statista.com/statistics/710474/number-of-outbound-trips-in-the- european-unionby-country/ abgerufen

Statista. (19. 082019 (g)). Von Leading city destinations in Europe from 2016 to 2018, by number of international arrivals: https://www.statista.com/statistics/487572/leadingeuropean-city-destinations/ abgerufen

Statista. (21. 082018 (b)). Global travel and tourism industry - Statistics \& Facts. Von Statista: https://www.statista.com/topics/962/global-tourism/ abgerufen

Statista. (21. 11 2019). Social media \& user generated content. Von Most popular social netwoks worldwide as of October 2019, ranked by number of active users in millions: https://www.statista.com/statistics/272014/global-social-networks-ranked-by- number-ofusers/ abgerufen

Statista. (22. 072019 (j)). Social media \& user generated content. Von Most popular reasons for internet users worldwide to use social media as of 4th quarter 2018:

https://www.statista.com/statistics/715449/social-media-usage-reasons-worldwide/ abgerufen

Statista. (25. 072019 (h)). Statists. Von Statistiken zum Reiseverhalten der Deutschen: https://de.statista.com/themen/1342/reiseverhalten-der-deutschen/ abgerufen

Sujana, A. (2015). Tourism Marketing: Opportunities and Challenges of Online Modes. In Hospitality, Travel and Tourism: Concepts, Methodologies, Tools and Applications (S. 3650). Hershey: IGI Global.

Swarbrooke, J., \& Susan, H. (2007). Consumer Behaviour in Tourism. Elsevier.

Telegraph. (28. 02 2017). The Telegraph. Von Humourless and nude': The truth about German holidaymakers:

https://www.telegraph.co.uk/travel/destinations/europe/germany/articles/german- tourists-thestereotypes-and-the-truth/ abgerufen

Tham, A., Mair, J., \& Croy, G. (2019). Social media influence on tourists' destination choice: importance of context. Tourism Recreation Research, 1-15.

The Economist. (2013. 10 2013). The Economist. Von Why is Brazil so expensive? https://www.economist.com/the-economist-explains/2013/09/30/why-is-brazil-so- expensive abgerufen

Tyagi, A. (2018). A study on factors affecting consumer buying behaviour. International of Business and Research, 1-7. 


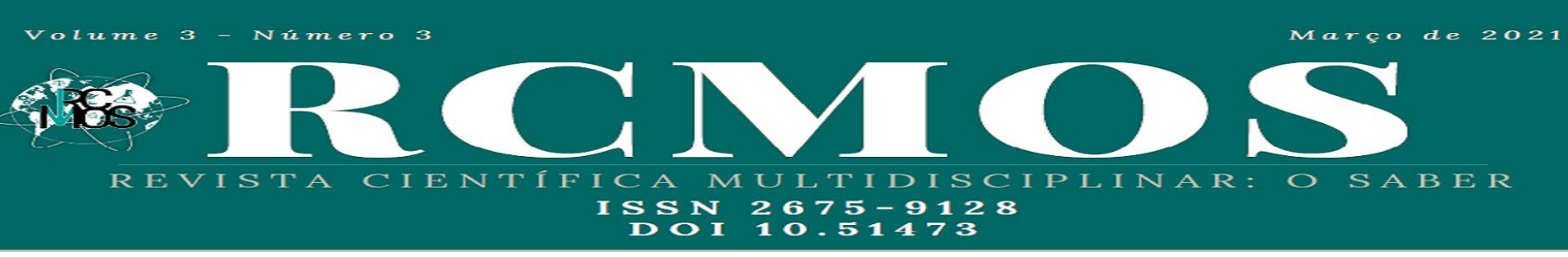

United Nations. (2010). International Recommendations for Tourim Statistics 2008. New York: United Nations Publication.

Vengesayi, S. (2009). Tourosm destination attractivess: Attraction's facilities, and people as predictors. Tourism Analysis, 621-636.

Wang, D., \& Siegel, L. (2019). Keeping up with the joneses: emergence of travel as a form of social comparison among millennials. Journal of travel \& tourims marketing, 159-175.

Wiley, D. (03. 07 2019). How to Drive User-Generated Content Through Influencer Marketing? Von Forbes: https://www.forbes.com/sites/forbesagencycouncil/2019/07/03/howto-drive-user- generated-content-through-influencer-marketing/\#60afb49824b0 abgerufen

World Bank. (01. 03 2020). World Bank. Von Unemployment, total (\% of total labor force) (national estimate)-Brazil:

https://data.worldbank.org/indicator/SL.UEM.TOTL.NE.ZS?locations=BR\&view $=$ chart abgerufen

World Travel \& Tourism Council. (27. 02 2019). Travel \& Tourism continues strong growth above global GDP. Von https://www.wttc.org/about/media-centre/press- releases/pressreleases/2019/travel-tourism-continues-strong-growth-above-global-gdp/ abgerufen

WTTC. (03 2019). World Travel \& Tourism Council. Von Brazil 2020 Annual Research: Key Highlights: https://www.wttc.org/economic-impact/country-analysis/country- data/ abgerufen

WTTC. (27. 02 2019). World Travel \& Tourism Council. Von Travel and Tourism continues strong growth above global GDP: https://www.wttc.org/about/media-centre/pressreleases/press-releases/2019/travel-tourism-continues-strong-growth-above-global-gdp/ abgerufen

Wymbs, C. (2011). Digital Marketing: The time for a New "Academic Major" Has Arrived. Journal of Marketing Education, 93-106.

Xavier, M. (04. 07 2019). Latin America Business Stories. Von How Brazilians travel around the world: a comprehensive guide: https://abs.ebanx.com/en/articles/society/how- brazilianstravel-around-the-world-a-comprehensive-guide/ abgerufen

Yogesh, F., \& Yesha, M. (2014). Effect of social media on purchase decision. Pacific Business Review International, 45-51.

Yoon, Y., \& Uysal, M. (2005). An examination of the effects of motivation and satisfaction on destination loyalty: a structural model. Tourist Management, 45-56.

Young, A., \& Hinesly, M. (2012). Identifying Millennials' key influencers from early childhood: insights into current consumer preferences. Journal of consumer marketing, 146155 . 


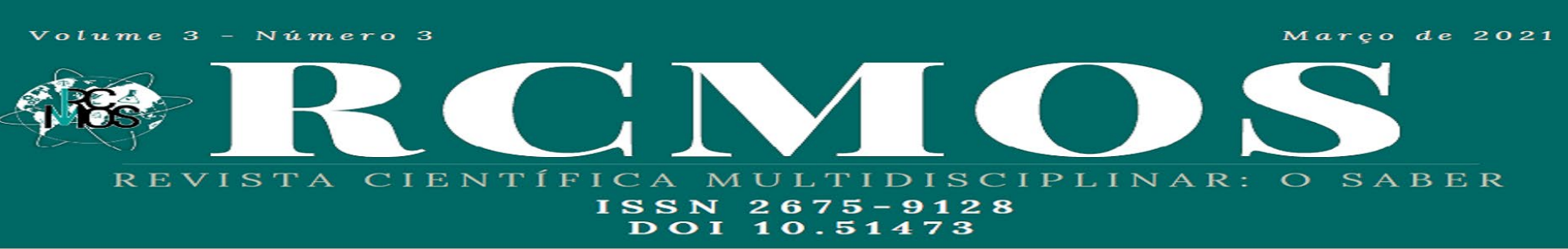

Zhang, X., \& You, W. (2019). Exploring short-form video application addiction: Sociotechnical and attachment perpectives. Telematics and informatics, 1-15.

Ziadat, M. (2015). Applications of Planned Behavior Theory (TPB) in Jordanian Tourism. International Journal of Marketing Studies, 96-106. 


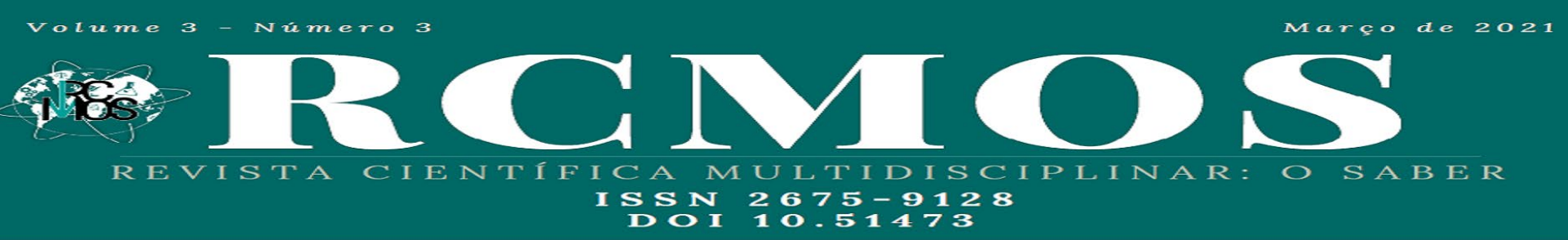

Appendix

\section{A.1 Online questionnaire}

\section{Influencer Marketing}

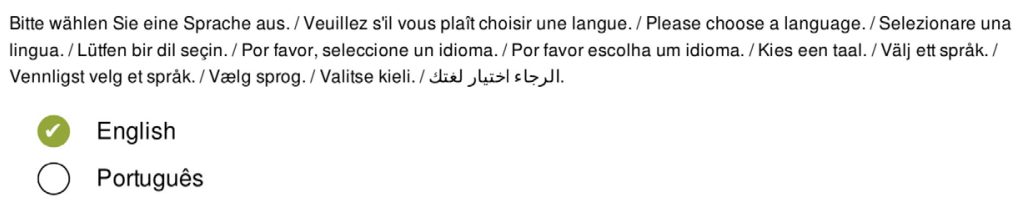

English

Português

Influencer Marketing

Dear Participant,

As part of my master thesis in a double degree in International Management. I am examining the travel behavior of millennials, including their choices and preferences of certain destinations.

It will take a maximum of 5-10 minutes to complete this survey.

All information will of course be treated anonymously and strictly confidentially and will only be used as part of my master thesis. A transfer to third parties is excluded.

I appreciate your support and thank you for your participation.

For further information or questions, I am available to you: gleice.seibel.2018@student.ism.de

\section{Personal details}

Please specify your gender? *

$\square$ Female

$\square$ Male

I'd rather not answer.

Other:

\section{Personal details}

What is your nationality? *

Brazilian

$\square$ German

$\square$ Other: 


\section{ISSN $2675-9128$
DOI}

\section{Statutory Declaration}

I confirm that this thesis ( 27000 words) is solely my own work and that it has not been previously submitted for assessment as a whole or in part, nor published.

All material which is quoted is accurately indicated as such, and I have acknowledged all sources employed fully and accurately.

Munich 10/08/2020

Place, date

(Signature)

\section{Further Declaration}

I agree with a plagiarism check of this thesis and know that the agreement of both experts is necessary for a publication.

Furthermore, I am completely aware that failure to comply with these requirements is a breach of rules and will result in resubmission, loss of marks, failure and/or disciplinary action.

Munich 10/08/2020

Place, date

(Signature) 


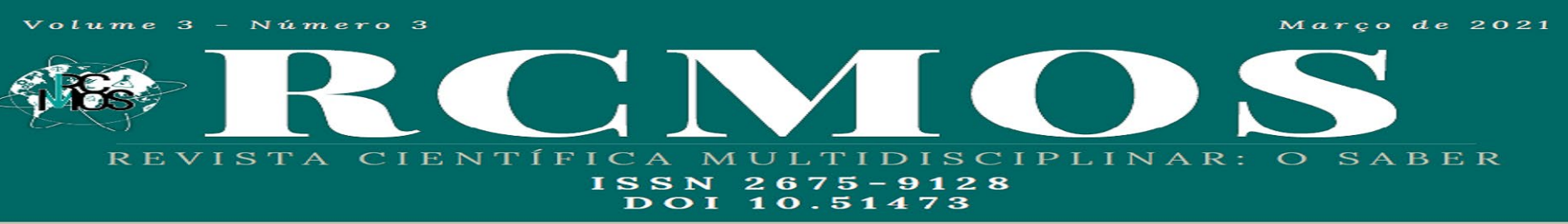

O USO DA TECNOLOGIAS DIGITAIS NO DESENVOLVIMENTO DAS CRIANÇAS COM TRANSTORNO DE ESPECTRO AUTISTA

THE USE OF DIGITAL TECHNOLOGIES IN THE DEVELOPMENT OF CHILDREN WITH AUTISTIC SPECTRUM DISORDER

RIBEIRO, Sérgio Fernando C. ${ }^{1}$ CONRADO, Luciane ${ }^{2}$ LEGEY, Ana Paula ${ }^{3}$

\begin{abstract}
RESUMO
Este trabalho tem por objetivo oferecer uma forma mais ampla e abrangente de atendimento aos autistas, levando-se em conta suas características e peculiaridades, notadamente nos aspectos voltado para a inclusão escolar desses alunos especiais nas escolas regulares da rede de ensino. Através do trabalho docente apoiado em tecnologias digitais, que incluem games e outras formas divertidas de aprendizagem, pode-se trabalhar em um ambiente escolar repleto de alegria e satisfação para esses alunos que apresentam Necessidades Educativas Especiais. Para isso, é necessário o aprimoramento dos conhecimentos sobre esse tema, que aborda os indivíduos acometidos de TEA, (Transtornos do Espectro Autista), as causas, os sintomas, as características e os tratamentos. A criança autista pode apresentar dificuldades de relacionarse com os outros alunos, mas é possível trabalhar com ela desde pequena, ajudando-a a se sentir confortável e feliz na sua turma e na escola como um todo. A pesquisa bibliográfica relativa ao tema traz valiosos e importantes subsídios para a compreensão dos problemas decorrentes do autismo, bem como das práticas necessárias ao desenvolvimento da atividade docente que busca a inclusão escolar de alunos que apresentam problemas psicológicos, de convivência e de comportamento social. Torna-se necessário e fundamental buscar entender o que é Autismo, aprofundando os conhecimentos sobre Autismo, abordando as causas, sintomas e os tratamentos existentes. É também necessário conhecer experiências de trabalho escolar com alunos autistas, onde se incluem as tecnologias digitais como o jogo digital "ABC do autista". É papel primordial dos docentes compreender as dificuldades dos seus alunos, sejam elas quais forem, e buscar soluções profissionais para minimizar ou mesmo eliminá-las das tarefas escolares. $\mathrm{O}$ docente deve sempre agregar características afetivas e emocionais positivas, para que se mantenha a motivação e o interesse do aluno autista.
\end{abstract}

Palavras-chave: TEA, autismo, inclusão escolar, tecnologia digital

\title{
1 INTRODUÇÃO
}

A constante modernização das estratégias e técnicas profissionais que envolvem o setor educacional objetivam a inclusão, nas escolas regulares, das crianças e jovens que

\footnotetext{
${ }^{1}$ I Encontro Unicarioca de Aprendizagem e novas tecnologias. Centro Universitário Unicarioca.

${ }^{2}$ Orientadora.

${ }^{3}$ Orientadora

RCMOS - Revista Científica Multidisciplinar O Saber. ISSN: 2675-9128. DOI 10.51473. São Paulo, v. 03, p. 01-06, mar. 2021.
} 


\section{Volume 3-Numero 3

apresentam as mais diferentes deficiências, sejam elas físicas, intelectuais, psicológicas ou comportamentais, incluindo-se também o trabalho das práticas docentes com crianças autistas.

A partir de uma formação docente que tem por objetivo ampliar a aceitação e o respeito ao ritmo de aprendizagem dos alunos, verifica-se que aqueles alunos que apresentam dificuldades de aprendizagem costumam ser considerados como problemáticos, muito mais em função do despreparo dos docentes para enfrentar as situações de anormalidade dentro do ambiente escolar. Em muitos casos, o aluno problemático ou com deficiência, é deixado de lado por que não se adequa ao ritmo de aprendizagem do restante da turma.

Com as crianças autistas esse procedimento de descaso pode levar o aluno a se isolar ainda mais, impedindo totalmente a sua inclusão na escola, no seu grupo de colegas e mesmo na vida social como um todo.

Existe, portanto, a necessidade imediata de oferecer estratégias e métodos docentes que contemplem, ainda que de forma parcial, a autonomia do autista. Essa problemática pode ser minimizada e até mesmo resolvida com a introdução das tecnologias digitais como ferramenta de trabalho docente.

O Referencial Curricular Nacional para a Educação Infantil (RECNEI), no seu adendo sobre "Estratégias e Orientações para a Educação de Crianças com Necessidades Educacionais Especiais (RECNAD)" faz uma avaliação das deficiências mentais que subentendem algumas características autistas e que devem ser atendidas dentro do ambiente escolar regular.

Os jogos digitais apresentam uma característica atrativa e agradável aos autistas, facilitando muito a interlocução e a interação social com os alunos portadores de TEA. Os recursos tecnológicos como computadores, tablets, brinquedos digitais estão sendo cada vez mais usados como aliados na educação tanto de crianças, como jovens e adultos, por conta de se tratar de métodos que proporcionam um método de aprendizagem mais ativo, onde o aluno está presente em todos os processos, construindo de uma forma só o seu conhecimento.

Temos que ter em mente que, mesmo a maioria dos indivíduos considerados normais, apresentam algumas deficiências de atenção e/ou de aprendizagem em certos momentos de sua aprendizagem escolar ou de seu desenvolvimento educacional e social, mas isso não significa necessariamente que devem ser tratados de forma diferenciada ou, como em muitos casos, deixados de lado. Os alunos se motivam por perceberem que podem ser capazes de desenvolver diferentes habilidades, como cognitivas, sensoriais, interacionais utilizando 


\section{Volume 3-Numero 3

que atendam às necessidades educacionais dos alunos, isto inclui aqueles com necessidades educacionais especiais.

Diferenciar o ensino é organizar as interações de modo que cada aluno se defronte constantemente com situações didáticas que lhe sejam mais fecundas (...) implica, pois, o desenvolvimento de caminhos diversos para que os alunos consigam atingir as metas escolares, por meio de um acompanhamento e percursos individualizados. (PERRENOUD, 1995, p.28-29)

É público e notório que as intervenções precoces em deficiências comportamentais, cognitivas ou da fala podem ajudar as crianças com autismo a ganhar autonomia e habilidades sociais e de comunicação.

Dessa forma, é possível auxiliar a criança a entender o que acontece no ambiente real e no dia a dia utilizando os recursos pedagógicos digitais, fazendo com que a convivência social das crianças autistas seja melhorada além de proporcionar uma melhor inclusão e qualidade de vida.

Neste Exposto, tem-se como objetivo é favorecer o processo de inclusão de todos os alunos que buscam a escola regular, notadamente aqueles que apresentam TEA. Nessa questão da inclusão de alunos especiais nas redes regulares de ensino público, a escola encontra-se perante um desafio: conseguir que todos os alunos tenham acesso à aprendizagem básica, por meio da inclusão escolar de todas as crianças, respeitando as diferenças culturais, sociais e individuais, que podem configurar as chamadas necessidades educacionais especiais (NEEs).

Não se trata apenas de receber os alunos especiais dentro da escola, mas de favorecer as possibilidades de socialização, de companheirismo, de aceitação e de valorização da autoestima desses alunos, que já enfrentam dificuldades em suas vidas diárias. (PAIVA, 2002)

A escola deve atuar como a facilitadora de todas as ações que envolvam a aprendizagem desses alunos que exigem NEEs, bem como trabalhar pela inserção deles no meio escolar e no meio social em que vivem.

Pode parecer paradoxal que uma instituição considerada "regular" deve atender às situações excepcionais de aprendizagem, mas é esse justamente a pedra fundamental desse processo de inclusão: a igualdade de oportunidades para todos que buscam a escola.

Não cabe ao setor educacional selecionar, diferenciar e estigmatizar as pessoas em razão das suas habilidades e/ou dificuldades. cabe sim aceitar as diferenças e trabalhar em prol do crescimento de todos. Nesse sentido, o trabalho com alunos autistas ganha dimensão 


\section{Volume 3 - Numero 3

\section{REFERÊNCIAS}

BRASIL/MEC - RECNAD. Referencial Curricular Nacional para a Educação Infantil: Estratégias e Orientações para a Educação de Crianças com Necessidades Educacionais Especiais. Brasília: MEC, 2000.

BRASIL, Presidência da República. Lei n. 12.764, de 27 dez.2012.

Disponível em:

http://www.planalto.gov.br/ccivil_03/_ato2011-2014/2012/lei/112764.htm

Acesso em: 22 set. 2019.

DSMS - 5. Criteria. 2012. Disponível em: https://www.autismspeaks.org/dsm-5-criteria. Acesso em: 27 set. 2019.

PAIVA JUNIOR, F. 2012. Autismo - Não espere, aja logo! Depoimento de um pai sobre os sinais de autismo 1 ed. São Paulo: M. Books. 136 p.

PERRENOUD, P. Ofício de aluno e sentido do trabalho escolar. Porto: Porto Editora, 1995. 


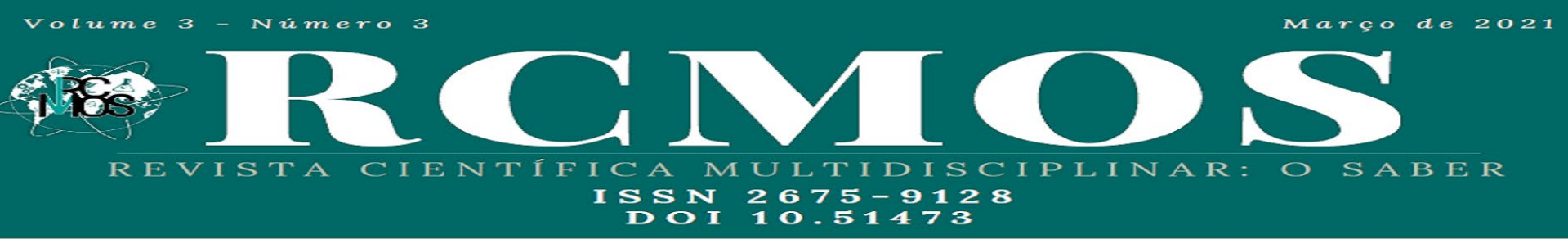

\title{
A importância da Biologia Molecular no diagnóstico do SARS-CoV-2
}

\author{
The importance of Biology Molecular on diagnosis of SARS-CoV-2 \\ VELOZO, Ana Clara Costa ${ }^{1}$ \\ PEIXOTO, Fernanda Gabriela de Souza ${ }^{2}$
}

\section{Resumo}

A pandemia causada pelo agente etiológico SARS-CoV-2, teve início do ano de 2020 e gerou um grande desafio na comunidade científica de todo o mundo. Seus sintomas podem variar de manifestações leves à quadros severos de pneumonia. Estudos estão buscando elucidar maneiras de prevenção, diagnóstico e tratamento da doença. Diante o cenário pandêmico, e o agravamento no número de casos e óbitos pela doença, a busca por um diagnóstico preciso é imprescindível. Portanto, o objetivo deste estudo é demonstrar a importância da utilização da biologia molecular através da técnica de Real Time Reverse Transcriptase Polymerase Chain Reaction (Real Time RT- PCR), para a detecção do material genético do SARS-CoV-2 a partir de dados encontrados na literatura. Após análise crítica da literatura, foi possível confirmar a importância e eficiência da utilização da técnica de Real Time RT-PCR no diagnóstico da infecção, uma vez que essa técnica possibilidade um bom desempenho na detecção do material genético viral, garantindo alto índice de acerto ao diferenciar um paciente infectado do nãoinfectado. Concluindo que até o momento esta técnica é considerada como o principal método diagnóstico para a doença, permanecendo assim como "padrão ouro".

Palavras-Chave: Biologia Molecular, SARS-CoV-2, Corona Vírus, Diagnóstico, Real Time $R T-P C R$

\begin{abstract}
The pandemic caused by the etiologic agent SARS-CoV- 2, started at the beginning of 2020 . And create a big challenge in the scientific community from all around the world. The symptoms can variate of levels manifestation to severs cases of pneumonia. Studies are seeking ways of prevention, diagnosis and treatment of the disease. In view of the pandemic scenario and the worsening number of cases and deaths due to the disease, the search for an accurate diagnosis is essential. Therefore, the aim of this study is demonstrating the importance of using molecular biology through the technique of Real Time Transcriptase Reverse Polymerase Chain Reaction (Real Time RT-PCR), for the detection of the genetic material of SARS-CoV-2 from data found in the literature. After a critical analysis of the literature, it was possible to confirm the importance and efficiency of using the Real Time RT-PCR technique in the diagnosis of infection, since this technique allows a good performance in the detection of viral genetic material, guaranteeing a high success rate when differentiating an infected patient from the noninfected. Concluding that until now this technique is considered as the main diagnostic method for the disease, remaining as a "gold standard".
\end{abstract}

Keywords: Molecular Biology, SARS-CoV-2, Corona Virus, Diagnoses, Real Time RT-PCR.

\footnotetext{
1 Graduação em Biomedicina. Centro Universitário de Belo Horizonte - UNIBH. Minas Gerais, Brasil. anaclaracvelozo@outlook.com.

2 Graduada em Biomedicina. Centro Universitário de Belo Horizonte - UNIBH. Minas Gerais, Brasil. peixotofernanda@outlook.com.
} 


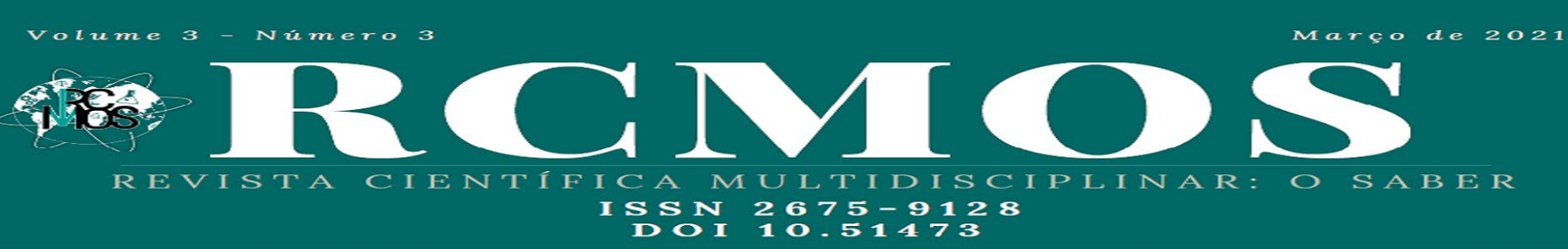

\section{Introdução}

No início do ano de 2020, pesquisadores chineses identificaram um novo coronavírus, após um surto de doenças respiratórias que ocorreu na cidade de Wuhan, na China. Este novo vírus identificado recebeu o nome de Severe Acute Respiratory Syndrome Coronavirus 2 (Síndrome Respiratória Aguda Grave de Coronavírus 2). Nome dado devido a sua semelhança com o vírus SARS-CoV, que surgiu também na china e matou cerca de 700 pessoas.

Diferentemente do surto epidêmico do primeiro coronavírus, o SARS-CoV-2 se disseminou por todo planeta, o que deu início a uma pandemia que até o presente momento causou cerca de 2.300.000 mortes no mundo (OPAS, 2021).

Perante ao cenário pandêmico causado pelo SARS-Cov-2 diversos desafios surgiram para compreensão da doença nomeada de Coronavirus Disease 2019. Tais como prevenção, diagnóstico e tratamento. Desde então, cientistas de todo o mundo buscam respostas para estes questionamentos. Com pesquisas de novos testes para detecção, buscas por tratamentos e vacinas.

Até o presente momento a técnica considerada padrão ouro para a detecção do agente etiológico da COVID-19 é a técnica de biologia molecular, chamada de Real Time Reverse Transcription Polimerase Chain Reaction). Técnica a qual amplifica o material genético do vírus presente na amostra do paciente infectado.

Diante o exposto, o presente estudo tem como objetivo demonstrar a importância da utilização da biologia molecular através da técnica de Real Time RT-PCR, para a detecção do material genético do SARS-CoV-2 através de uma revisão da literatura. Para a construção do trabalho foi realizada uma pesquisa bibliográfica nas bases de dados Eletronic Library Online (SCIELO), Ministério da Saúde e Revistas Eletrônicas.

\section{Fundamentação teórica}

\subsection{O Coronavírus}

Os coronavírus são uma grande família de vírus comuns em muitas espécies diferentes de animais, incluindo camelos, gado, gatos e morcegos (MINISTÉRIO DA SAÚDE, 2021). A COVID-19 é uma doença causada pelo coronavírus, denominado SARS-CoV-2, vírus pertencente à família Coronaviridae. Estes, podem causar uma variedade de doenças no homem e nos animais, especialmente no trato respiratório (MINISTÉRIO DA SAÚDE, 2021). 


\section{Volume 3 - Número 3

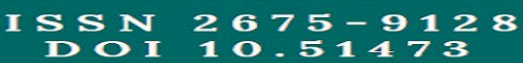

Trata-se de um vírus de RNA + de fita simples, e partículas esféricas com cerca de 125 nm de diâmetro, revestidas por um envelope fosfolipídico. Suas partículas apresentam projeções formadas por trímeros da proteína S (spike protein), dando-lhes o formato de espículas, também conhecido como coroa (USP, 2020).

Figura 1 - Estrutura viral do coronavírus

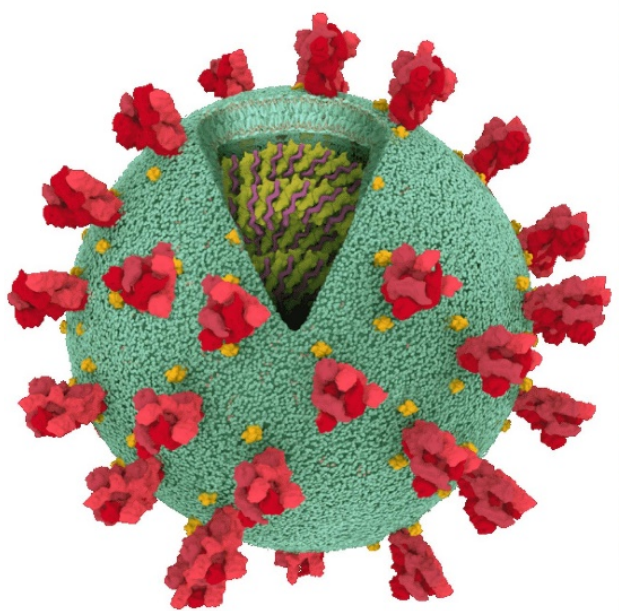

Fonte: UZUNIAN, 2020.

$\mathrm{O}$ vírus se liga a células do hospedeiro através da proteína $\mathrm{S}$, a qual interage com os receptores proteicos e a enzima conversora de angiotensina 2 (ACE2) presente principalmente nas células pulmonares (USP, 2020).

Figura 2 - Estrutura de uma partícula viral do coronavírus

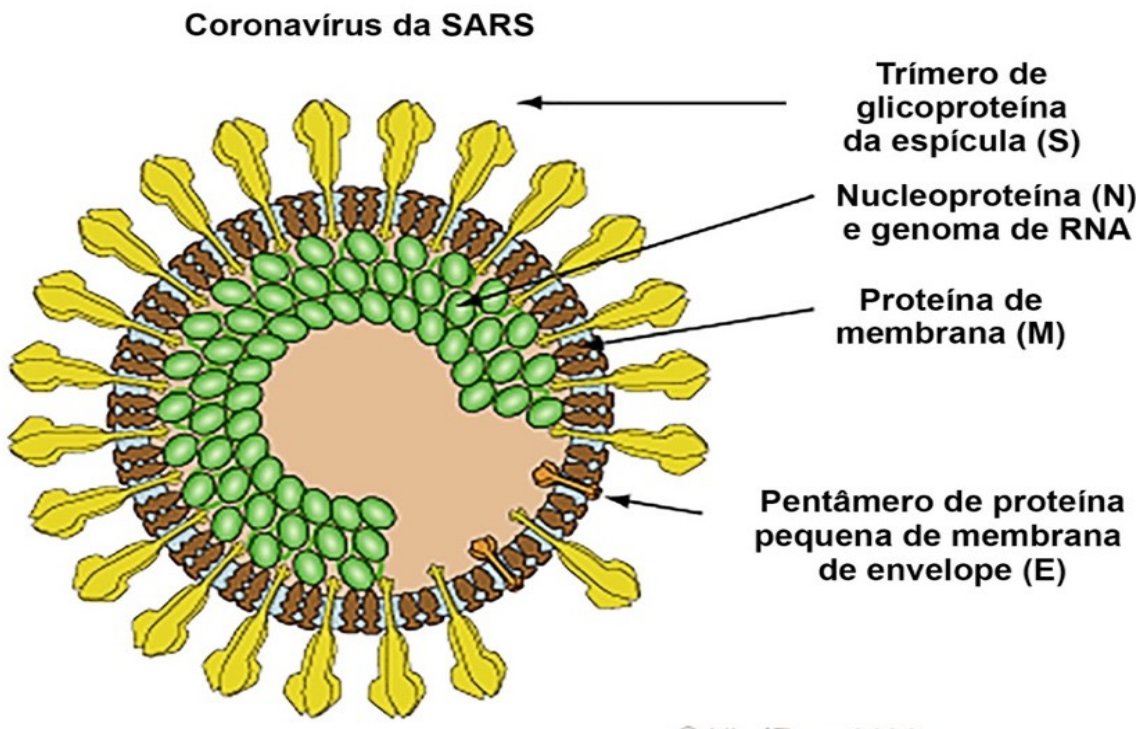

(5) ViralZone 2020

SIB Swiss Instute of Bioinformatics

Fonte: https://viralzone.expasy.org/30 


\section{Votume 3 - Número 3

Após a introdução do material genético no interior da célula, uma vesícula celular é formada e em seu interior (endossomos) o vírus é retido e multiplicado. Posteriormente, as moléculas de RNA+ produzidas dentro dos endossomos são liberadas, e a síntese das proteínas virais acontece (UZUNIAN, 2020).

Figura 3 - Esquema da replicação viral RNA +

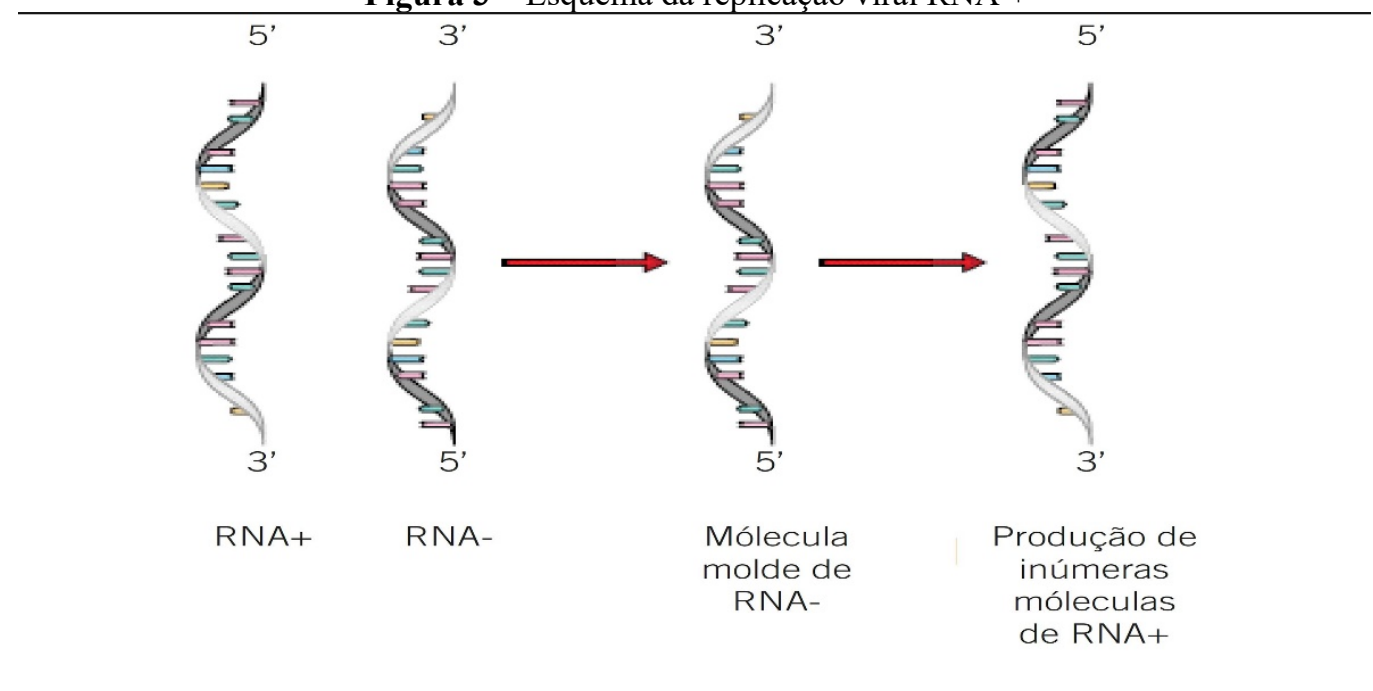

Fonte: UZUNIAN, 2020.

As manifestações clínicas causadas pelo vírus são muito amplas, podendo variar de sintomas leves como um resfriado, febre, tosse, dificuldades para respirar, até um quadro de pneumonia severa. Dados atuais demonstram a necessidade de investigação e tempo para caracterizar os aspectos clínicos da infecção pelo novo coronavírus (MINISTÉRIO DA SAÚDE, 2019).

No que tange ao diagnóstico clínico e laboratorial, recomenda-se que ocorra uma investigação clínico - epidemiológica, exame físico, seguido do diagnóstico por meio das técnicas de Real Time RT-PCR (MINISTÉRIO DA SAÚDE, 2019).

\subsection{Reação em cadeia da polimerase (PCR)}

A reação em Cadeia Polimerase (PCR), foi desenvolvida nos anos 80 por Kary Mullis, um bioquímico estadunidense que ganhou o prêmio Nobel de química em 1993 pela sua descoberta, que revolucionou o mundo da pesquisa científica (MELLO, 2005).

A PCR é uma técnica da Biologia Molecular que através de enzimas consegue amplificar de maneira exponencial uma sequência específica de DNA in vitro através de 


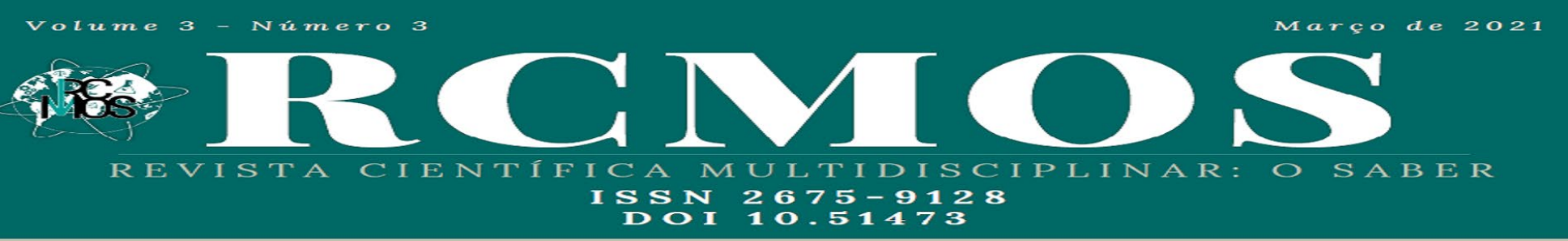

do RNA, que são ricas em adeninas. A partir de então se obtém o cDNA que será utilizado na PCR (SANTOS et. al. 2004).

\subsection{Real time RT-PCR para diagnóstico de Sars-Cov-2}

Algumas viroses, como o SARS-Cov-2 contém somente RNA como o material genético, portanto é necessário a realização da conversão do RNA em DNA (IAEA, 2020). O diagnóstico do novo coronavírus é feito através da técnica de biologia molecular Real Time - RTPCR, um método derivado da PCR convencional. Utilizando, além dos componentes da PCR convencional, a enzima transcriptase reversa um marcador radioisótopo que gera fluorescência durante os ciclos da PCR. Este método permite que os cientistas vejam o resultado quase instantaneamente a ocorrência do procedimento através da análise da fluorescência em um computador que rastreia a quantidade de fluorescência a cada ciclo. Já a RT-PCR convencional só permitiria a visualização só resultado ao final da amplificação através da Eletroforese (IAEA, 2020).

A técnica de Real Time RT-PCR é uma técnica com alta sensibilidade e especificidade, com resultado em cerca de três horas. (IAEA, 2020). A amostra é colhida através de um swab nasal e nasofaríngeo. Para realizar a detecção viral, é necessário fazer a amplificação do material genético do vírus presente na amostra do paciente, através da Real Time RT-PCR. (SES, 2021).

Figura 4 - Esquema coleta de secreção em nasofaringe.

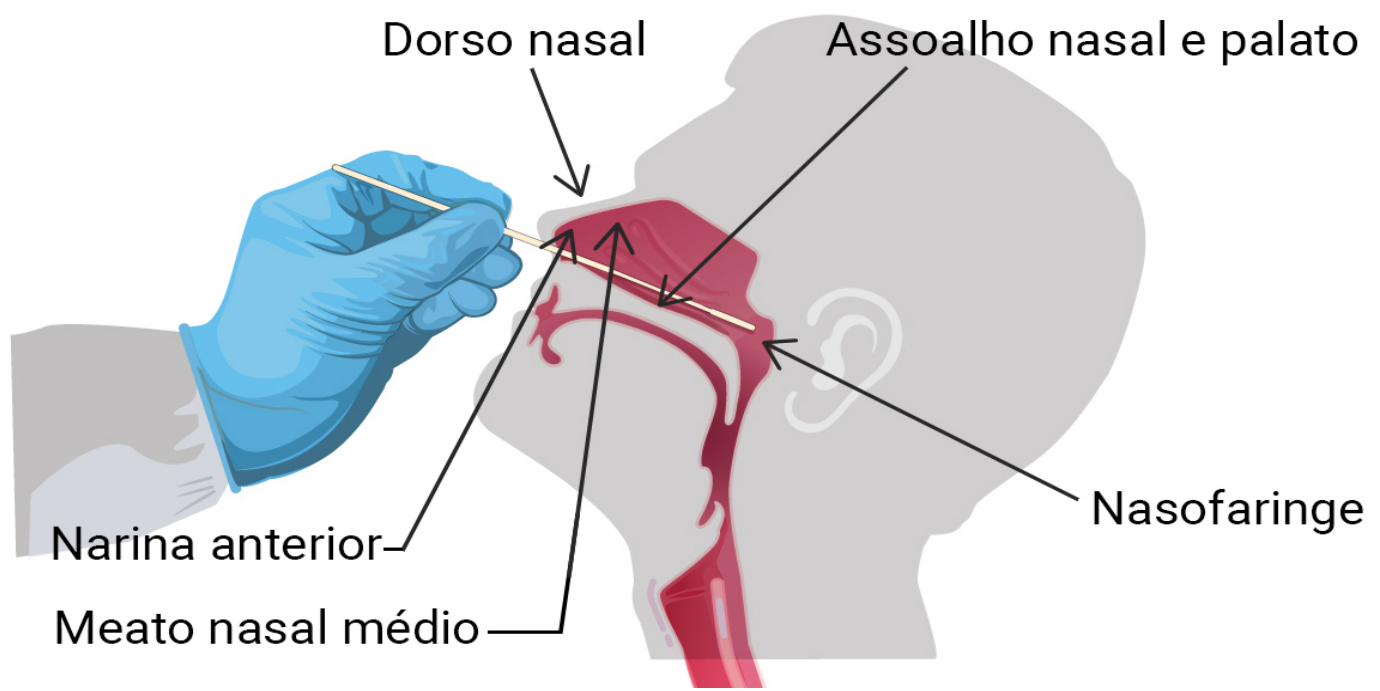

Fonte: https://www.nupad.medicina.ufmg.br/doencas-infecciosas/instrucoes-coleta-covid-19/ 


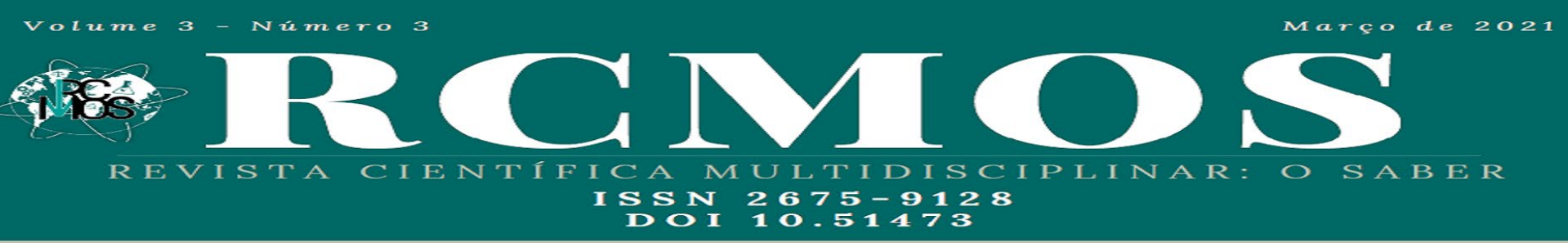

O diagnóstico através da técnica de Real Time RT- PCR é indicado, entre o $3^{\circ}$ e $4^{\circ}$ dia da doença, podendo se estender até o $10^{\circ}$ dia. Seu objetivo é obter uma amostra das secreções respiratórias, identificando posteriormente a presença do vírus.

O Real Tine RT-PCR é um exame qualitativo de excelente sensibilidade, com alta capacidade de diferenciar um paciente infectado do não-infectado. Sendo então considerado o exame ideal para diagnóstico de covid-19 (SES, 2021).

\section{Considerações finais}

Perante o que foi encontrado na literatura durante a construção do trabalho, é possível afirmar que as técnicas de Biologia Molecular são consideradas padrão ouro ou referência para detecção de agentes infecciosos. Confirmando a importância da Biologia Molecular no diagnóstico do SARS-CoV-2, através da técnica de Real Time RT-PCR.

Portanto, é possível afirmar que a utilização desta técnica molecular tem sido, até o presente momento o principal e mais seguro método para o diagnóstico da doença causada pelo agente etiológico SARS-Cov-2, a COVID19.

\section{Referências}

HAAS, D. J; TORRES, A, C, D. Aplicações das técnicas de PCR no diagnóstico de doenças infecciosas dos animais. Revista Científica De Medicina Veterinária. n.26. Belo Horizonte, 2016. Disponível em:

http://faef.revista.inf.br/imagens_arquivos/arquivos_destaque/5D3Iu05EHeEnqP1_2017-1-128-29-47.pdf. Acesso em: 02 mar. 2021.

INTERNATIONAL ATOMIC ENERGY AGENCY. How is the COVID-19 virus detected using real time RT-PCR? Estados Unidos, 2020. Disponível em:

https://www.iaea.org/bulletin/infectious-diseases/how-is-the-covid-19-virus-detected-usingreal-time-rt-pcr. Acesso em: 03 mar. 2021.

MELLO, F. C; COSTA, J. F. The utility of molecular biology in the diagnosis of tuberculosis. Jornal Brasileiro de Pneumologia. v.31.n.03. Brasil, 2005. Disponível em:

http://www.jbp.org.br/details/1429/en-US/a-utilidade-da-biologia-molecular-no-diagnosticoda-tuberculose. Acesso em: 03 mar. 2021.

MINISTÉRIO DA SAÚDE. Protocolo de tratamento do Novo Coronavírus. Brasília 2020. Disponível em: https://portaldeboaspraticas.iff.fiocruz.br/wpcontent/uploads/2020/03/Protocolo-de-manejo-clinico-para-o-novo-coronavirus-2019ncov.pdf. Acesso em: 02 mar. 2021.

MINISTÉRIO DA SAÚDE. Sobre a doença- Coronavírus. Brasil, 2021. Disponível em: https://coronavirus.saude.gov.br/sobre-a-doenca. Acesso em: 02 mar. 2021. 


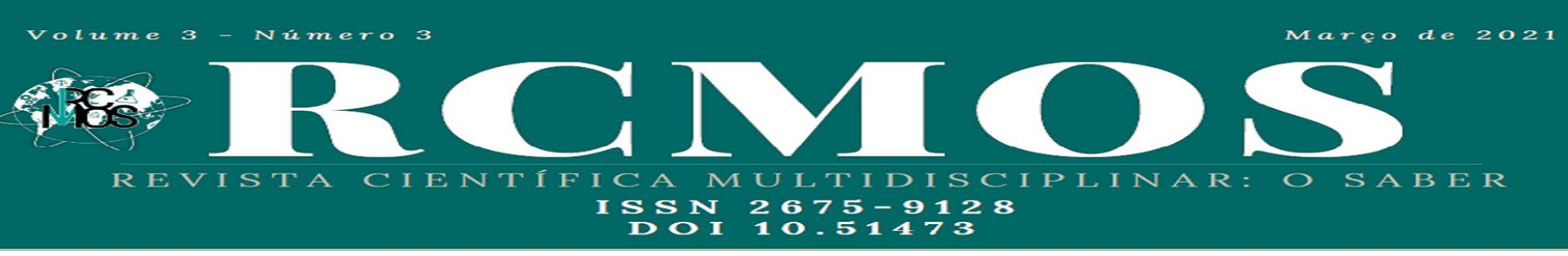

ORGANIZAÇÃO PAN-AMERICANA DA SAÚDE (OPAS). Folha informativa COVID-19. Escritório das OPAS e da OMS no Brasil. Brasil, 2021. Disponível em:

https://www.paho.org/pt/covid19. Acesso em: 02 mar. 2021

PORTAL DA USP. Covid-19: o que se sabe sobre a origem da doença. Ribeirão Preto, 2020. Disponível em: https://jornal.usp.br/artigos/covid2-o-que-se-sabe-sobre-a-origem-da-doenca/. Acesso em: 02 mar. 2021.

SANTOS, C, F. et. al. Reverse transcription and polymerase chain reaction: principles and applications in dentistry. Journal of Applied Oral Science. v.12. n.1. Bauru, 2004. Disponível em: https://www.scielo.br/scielo.php?script=sci_arttext\&pid=S167877572004000100002. Acesso em: 03 mar. 2021.

SECRETARIA DE ESTADO DE SAÚDE DE MINAS GERAIS (SES). Quando deve ser feito o pcr-rt para coronavírus? Minas Gerias, 2021. Disponível em:

https://coronavirus.saude.mg.gov.br/blog/70-pcr-rt-para-coronavirus. Acesso em: 03 mar. 2021.

UZUNIAN, A. Coronavírus SARS-CoV-2 e Covid-19. Jornal Brasileiro de Patologia e Medicina Laboratorial. v.56. Rio de Janeiro, 2020. Disponível em: https://www.scielo.br/scielo.php?pid=S167624442020000100051\&script=sci_arttext\&tlng=pt. Acesso em: 02 mar. 2021. 


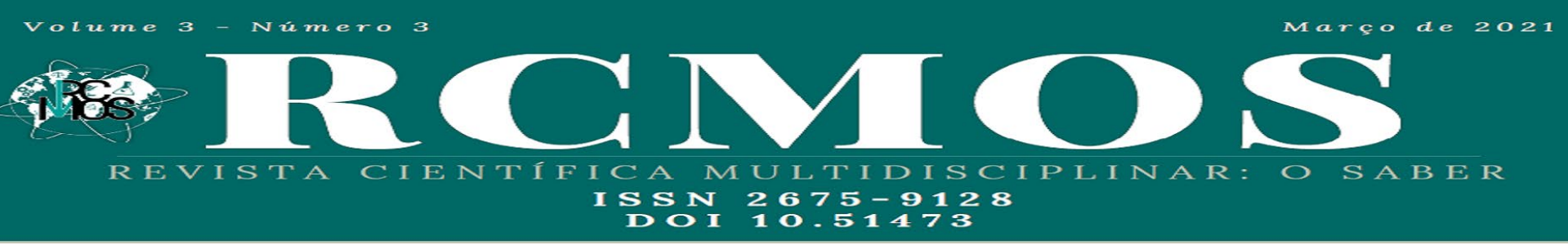

\title{
MULHERES DOCENTES NO ENSINO SUPERIOR: DESAFIOS E SUPERAÇÕES
}

\section{TEACHING WOMEN IN HIGHER EDUCATION: CHALLENGES AND OVERCOMING}

\author{
SOUZA, Solange de ${ }^{1}$ \\ HEIN, Adriana Kroenke ${ }^{2}$
}

\section{Resumo}

Ao longo da formação da sociedade brasileira, sabe-se que a mulher foi delegada a condições de subalternidade e servidão em relação aos homens, sendo sua atuação restrita às atividades domésticas e maternal. Mas, com a Revolução Industrial e, principalmente, a partir na década de 20, as mulheres, além de conquistar maiores direitos de estudos, passaram a ocupar funções na docência infantil. Esse quadro se alterou com o passar dos anos e o gênero feminino se fez presente também no ensino superior. Com esse pano de fundo, o objetivo geral do presente trabalho visa a compreensão da condição das docentes mulheres no ensino superior na tentativa de assimilar quais os principais pontos de desafios e superações a serem enfrentados. Para tal fim, fez-se uso de pesquisa exploratória e quantitativa, através do estudo de referencial teórico e da aplicação de questionários online, os quais possibilitaram o melhor entendimento acerca dos pontos relativos à atuação feminina na docência universitária brasileira.

Palavras-chave: Mulheres docentes. Ensino superior. Educação e sociedade.

\begin{abstract}
Throughout the formation of Brazilian society, it is known that women were delegated to conditions of subordination and servitude in relation to men, and their performance was restricted to domestic and maternal activities. But with the Industrial Revolution, and especially from the 1920s, women, in addition to gaining greater rights to study, began to occupy roles in child teaching. This picture changed over the years and the female gender was also present in higher education. With this background, the general objective of this paper aims to understand the condition of female teachers in higher education in an attempt to assimilate the main points of challenges and overcoming to be faced. To this end, exploratory and quantitative research was used, through the study of theoretical framework and the application of online questionnaires, which enabled a better understanding of the points related to female performance in Brazilian university teaching.
\end{abstract}

Keywords: Women teachers. Higher education. Education and society.

\footnotetext{
${ }^{1}$ Mestranda do curso de Pós-Graduação em Administração stricto senso. E-mail: solsouza@furb.br

${ }^{2}$ Pós-doutorado em modelos analíticos e de simulação pelo Instituto Nacional de Matemática Pura e Aplicada (Impa). Professor do Programa de Pós-Graduação em Ciências Contábeis da Universidade Regional de Blumenau (PPGCC/FURB). E-mail: akroenke@furb.br
} 


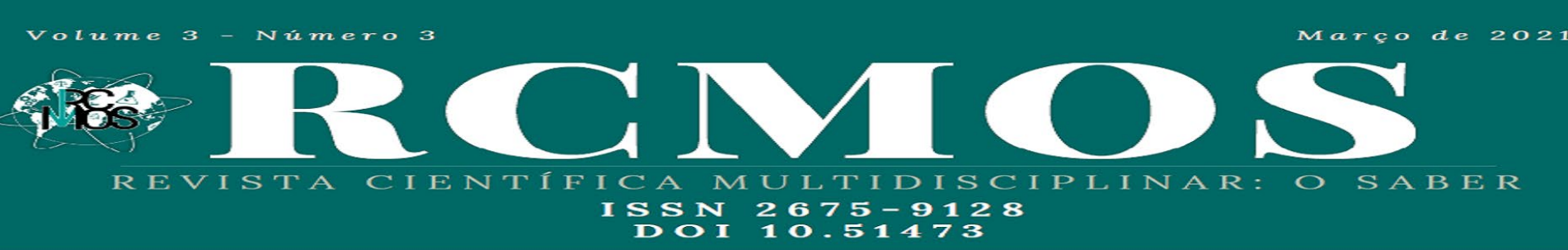

\section{Introdução}

Segundo Astelarra (1983), a condição feminina é algo bastante complexo na sociedade brasileira, o ser mulher nessa sociedade se mescla com nossas raízes, e relações sociais marcadas pelo patriarcalismo, autoritarismo e violência. Ao longo de toda a história do Brasil a mulher foi delegada a condições de subalternidade e servidão em relação aos homens. Podese dizer que essa situação é, em grande medida, marcada pelas origens colonizadoras e pela religiosidade cristã, claramente predominante no país.

Soares (1994) complementa que a vida das mulheres na sociedade brasileira é inapelavelmente atrelada a lutas, resistências, avanços e retrocessos na ânsia de respeito, posições sociais e direitos. Sendo essencial que as mulheres compreendam que toda e qualquer conquista é resultante de toda uma historicidade das mulheres que nos precedem.

Assim, o presente trabalho, com a temática da atuação das mulheres docentes no ensino superior, se apresenta como relevante, haja vista a historicidade que circunda o feminino no Brasil, já que esse grupo social é colocado em condição luta permanente. Diante das desigualdades presentes no Brasil entre os gêneros é demasiadamente urgente e necessário pensar e repensar o papel e a condição da mulher no país, a fim de propiciar o desvelar dessas contradições e possibilitar o avanço e conquistas deste gênero enquanto caminho para a libertação da humanidade das amarras do preconceito (PINTO, 2003).

Temos como objetivo geral do presente trabalho compreender a condição das docentes mulheres no ensino superior na tentativa de assimilar quais os principais pontos de desafios e de superações a serem enfrentados.

\section{Fundamentação teórica}

A fundamentação teórica contemplará a evolução, o panorama atual e a remuneração da participação feminina na atividade docente.

\subsection{Evolução da participação feminina na atividade docente}

Até a década de 1980, estudos referentes à educação no Brasil foi bastante limitado ao que tange as relações entre gênero e docência. Nos dias atuais, ainda se apresentam escassas as reflexões acerca da relação entre o feminino e a prática acadêmica (CASTRO; LAVINAS, 2002). Apesar da escassez de estudos, já foram consolidadas diversas associações entre 


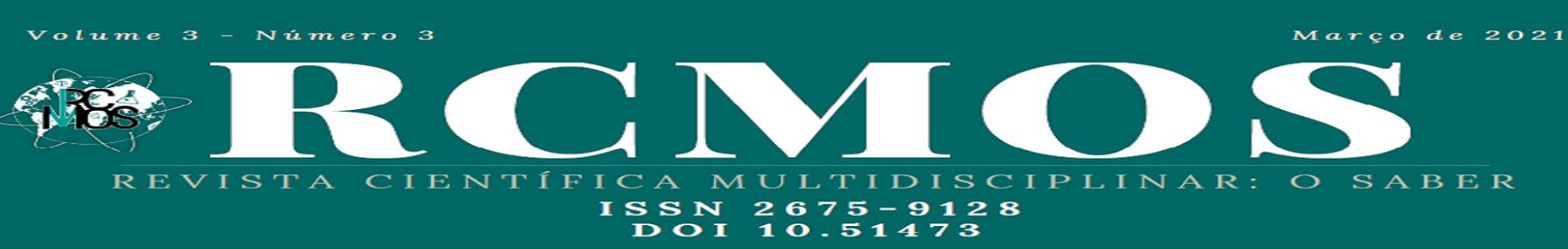

transitar de um lugar invisível e voltado às relações individuais para a visibilidade e coletivismo.

\subsection{Panorama atual da participação feminina na atividade docente}

Segundo estudo realizado pelo Instituto Nacional de Estudos e Pesquisas Educacionais Anísio Teixeira (INEP) em 2007, nota-se que o perfil predominantemente feminino dos docentes se modifica da educação infantil para o ensino médio e para a educação profissional (Gráfico 1). Pode-se notar que o predomínio feminino no universo docente se delimita, principalmente, às etapas iniciais de ensino, sendo que, já a partir do ensino regular, amplia-se a participação dos homens. Aquela que apresenta situação distinta é o ensino profissionalizante que abarca desde os cursos técnicos, tecnólogos e universitários.

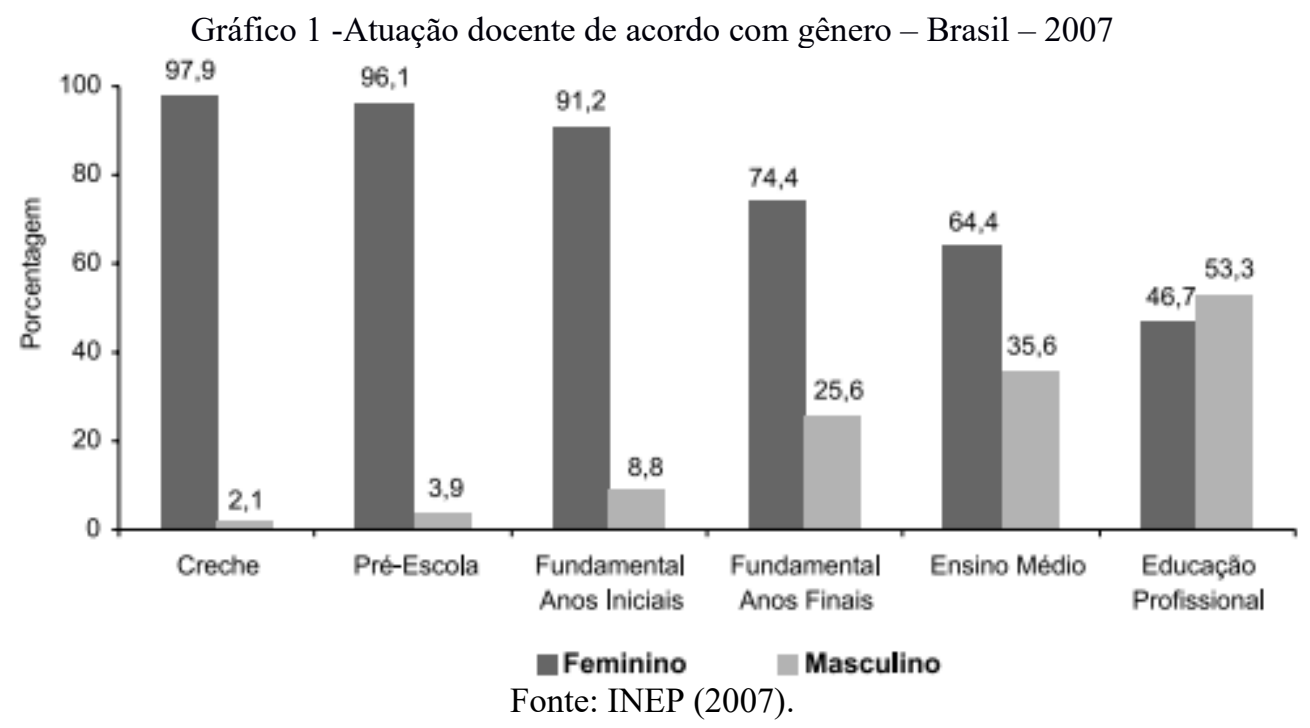

Pereira e Anjos (2014) retratam em seus estudos que, de acordo com o censo realizado em 2011 pelo INEP, existem 325.804 professores atuando no ensino superior no Brasil, sendo que desse grupo $60 \%$ se encontra em instituições privadas. Além disso, sabe-se que 16,5\% são doutores, $44,1 \%$ mestres e 39,4\% são especialistas, ratificando as afirmativas anteriores sobre a prevalência de docentes com maior nível de ensino dentro das universidades.

O censo de 2011 evidência, também, que o perfil do professor universitário, tanto em instituições privadas como públicas, é fortemente marcado pela presença dos homens. Nas instituições privadas são homens com idade média de 33 anos, mestres, horistas - aqueles que não atuam em período integral - e mestres. Já nas instituições públicas, esses possuem, em média, 47 anos, são doutores e atuam em período integral. 


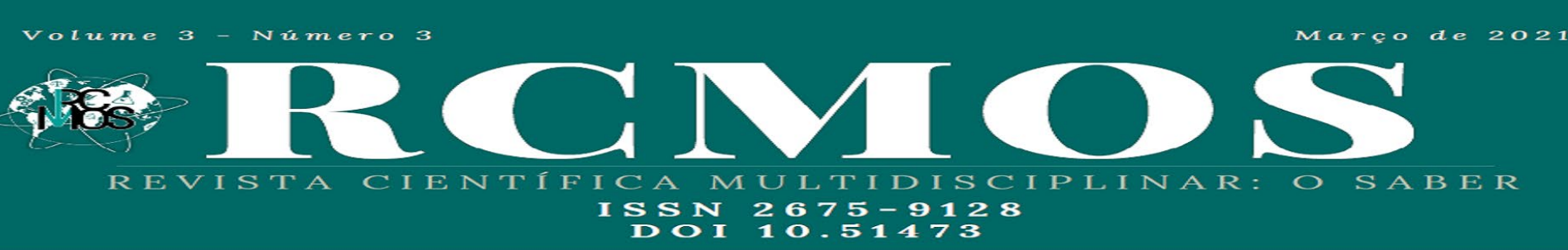

2.3 Remuneração da mulher na atividade docente

No desenvolvimento da pesquisa realizada por Araújo (2016), há a afirmativa de que a remuneração da atividade docente não apresentou distinção entre os gêneros, sendo estas decorrentes, com exclusividade, dos diferentes níveis de ensino. $\mathrm{Na}$ análise realizada, as mulheres com apenas o ensino primário (fundamental) ganhavam, substancialmente, menores salários do que aquelas com ensino secundário (médio). Como o ensino médio era composto, majoritariamente, por homens, estes possuíam as melhores remunerações.

Nesse sentido, pode-se afirmar que a diferenciação de salário vem, também, em decorrência da desigualdade de oportunidades, sendo que há maior acesso do gênero masculino à educação do que do feminino, principalmente nas classes baixas. Nota-se que o prestígio e salários do profissional docente aumentam conforme o nível de ensino alcançado e, como as mulheres ocupam, principalmente, o nível maternal, infantil e de ensino fundamental, essas recebem menores salários (ARAÚJO, 2016).

Rosemberg (2001) deixa evidente que as disparidades entre remunerações nos diferentes níveis de ensino estão reduzindo em função da "decorrência da composição sexual por nível e ensino, da melhoria média da formação inicial e da política salarial no sistema público" (ROSEMBERG, 2001, p. 525). Acrescenta-se, também, que apesar da preponderância masculina na análise dos salários, a força laboral na área docente é composta por $80 \%$ das mulheres, onde estas ocupam cargos que envolvem desde a lecionação, propriamente dita, como atividades administrativas.

De acordo com Mariussi et al. (2016), atualmente, pode-se perceber que há maior presença das mulheres nas universidades, sendo que esta foi alavancada também por conta das alterações realizadas na Lei de Diretrizes e Bases da Educação Nacional, em 2006, as quais propiciaram a proliferação de instituições universitárias privadas. A partir dessa prerrogativa, infere-se que o incremento da participação feminina atividades docentes de maior nível de ensino foi propiciada por sua maior inserção nas universidades.

\section{Metodologia}

A presente pesquisa utilizou como procedimento metodológico para análise de dados: o método exploratório-qualitativo. Nesta seção, em um primeiro momento, empreende-se em justificar a abordagem da pesquisa; em seguida, elucidam-se os processos e os critérios de escolha bibliográficas e da coleta de dados; por fim, discutem-se os aspectos da análise das 


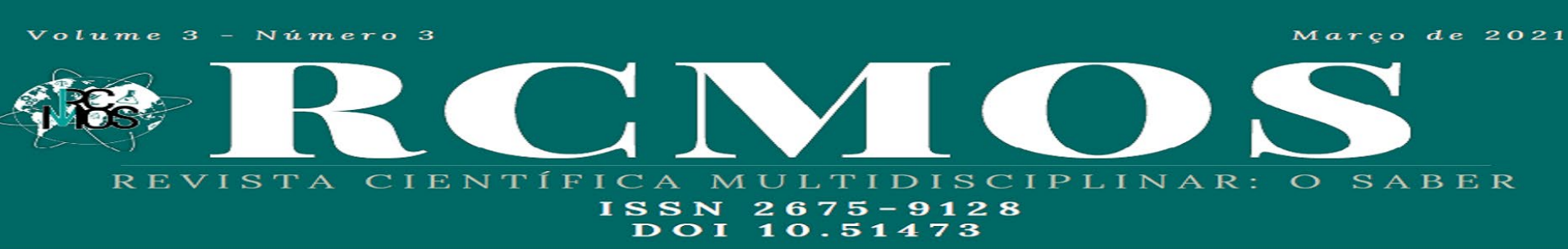

informações colhidas para a ratificação ou retificação das hipóteses desenvolvidas no decorrer da análise. Em meio ao processo, destacam-se características e possíveis interferências do ambiente para situar o contexto de pesquisa. Sobre os dados oriundos dos sujeitos, consideramse essas características e interferências no âmbito objetivo, já que se baseia nas respostas a questionários online.

\subsection{Posição exploratória da pesquisa}

A pesquisa exploratória traz a possibilidade de fornecer a hipótese da pesquisa a posteriori. Dessa forma, ela não segue a ordem de primeiro levantar uma hipótese e buscar dados empíricos, documentais ou formular uma racionalização para corroborá-la, mas empreender o esforço de compreender uma realidade e levantar as questões emergentes. Gil (2008) afirma que essas investigações possuem como finalidade principal o aperfeiçoamento de ideias ou a exploração de intuições.

\subsection{Posição qualitativa da pesquisa.}

A pesquisa quantitativa baseia-se na concepção científica moderna, que pode ser cristalizada na figura do positivismo. Nesse contexto, é forte a crença de que a ciência é imparcial, uma vez que se defende que os dados puros não têm lado, ou seja, são imparciais. No entanto, essa concepção restrita de ciência sofreu críticas contundentes que mostraram que os dados, em algum momento, possuem a intervenção do investigador. Essa visão de ciência "pura” é denominada por Chalmers e Fiker (1993) de ingênua.

$\mathrm{Na}$ educação, uma pesquisa estritamente quantitativa não parece ser adequada quando o objeto de investigação são orientações de práticas e de descoberta de concepções. Na pesquisa quantitativa, dá-se muito mais valor aos dados puros e como sua configuração pode dizer algo sobre uma hipótese do que a interpretação destes.

Um olhar qualitativo parece ser mais próximo dos fenômenos, característica esta que pode impedir a observância de um número grande de dados, o contrário de uma análise quantitativa, que abre mão de uma análise profunda dos dados para conseguir trabalhar com um número maior de informações, lançando mão de análises estatísticas e probabilísticas (BOGDAN; BILKEN, 1994).

Para Bogdan e Bilken (1994), a pesquisa qualitativa possuí cinco traços particulares. O primeiro é que esse tipo de investigação liga o investigador ao ambiente, pois, para analisar 


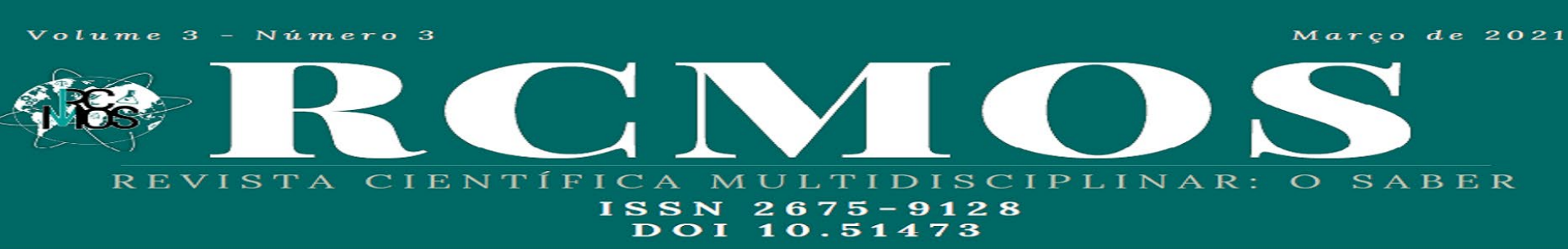

qualitativamente, é preciso apreender as situações cotidianas que modulam os significados daquele ambiente. Assim “[...] entendem que as ações podem ser melhores compreendidas quando são observadas no seu ambiente habitual de ocorrência." (BOGDAN; BIKLEN, 1994, p. 48).

O segundo traço corrobora exatamente o exposto há pouco: a investigação qualitativa gera dados descritivos. Em seguida, Bogdan e Bilken (1994) indicam como terceiro traço a importância do processo na investigação qualitativa. Este é considerado mais importante do que o produto da pesquisa por si só. Isso porque é o processo que vai gerar mais resultados para o investigador em um primeiro momento do que o próprio produto final. Nessa perspectiva, o processo de investigação é um transformador de significados, é ele que vai lançar as bases para um produto ou resultado final do qual o investigador sai profundamente transformado.

O quarto traço levantado por Bogdan e Bilken (1994) denota que a pesquisa qualitativa é essencialmente feita por meio de inferências dedutivas. No processo da pesquisa, ocorrem inúmeros raciocínios indutivos, não no sentido de levantar uma lei ou regra geral a partir de um processo indutivo ingênuo, mas a partir de uma cadeia indutiva feita, paulatina e continuamente, no processo de pesquisa.

O quinto traço da pesquisa qualitativa designa que a construção do significado é de vital importância para o processo. É por isso que o pesquisador faz levantamento do local, de suas respectivas características, da vida particular do sujeito da pesquisa e das suas impressões sobre determinado tema de maneira direta ou indireta por intermédio de entrevistas, observações, anotações, que dão origem às descrições do pesquisador qualitativo, com a finalidade de compreender mais nitidamente a perspectiva do sujeito da pesquisa.

Dessa forma, a presente pesquisa, ao explorar e analisar qualitativamente a prática da atuação da mulher na docência, levantou um entendimento sobre os problemas e desafios enfrentados por elas, frente à evolução histórica da sociedade patriarcal. Essa compreensão vem através de uma perspectiva construída por meio de um percurso sobre a bibliografia acerca da participação da mulher na atividade docente.

\subsection{Coleta de dados}

Para propiciar a coleta de dados referente à atuação da mulher na atividade docente e os desafios enfrentados, a pesquisa faz uso da aplicação de questionário online aplicado para 


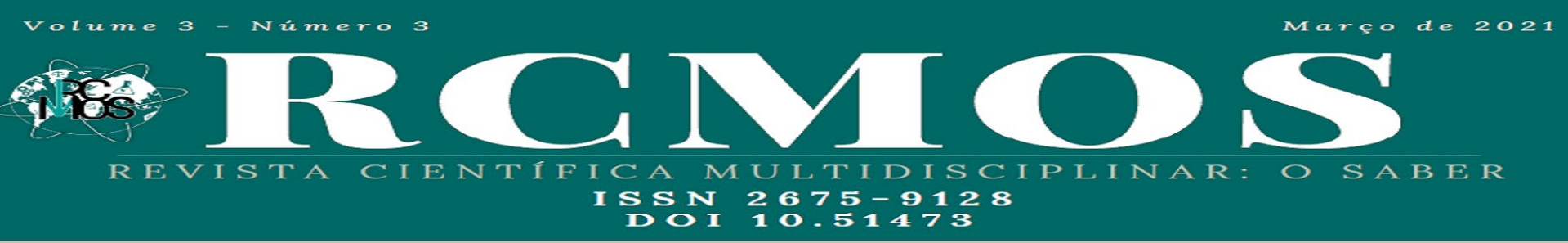

público selecionado e residente em Santa Catarina que terá acesso ao conteúdo através do link: https://www.onlinepesquisa.com/s/7bfdabd.

Nesse levantamento, o docente irá responder os seguintes dados: sexo; faixa etária; formação; rendimento mensal; tipo de Instituição de Ensino Superior (IES) em que atua; cidade que atua; tempo de atuação; modalidade de ensino. Assim, a respondente será questionada sobre os possíveis desafios existentes na docência no ensino superior abarcando questões relativas desde a carga excessiva de trabalho até a discriminação entre gêneros e oportunizando de descrever as possíveis formas de superar os desafios encontrados.

\section{Apresentação e análise dos resultados}

A princípio, é crucial relembrar que os resultados obtidos são oriundos de questionário online respondido apenas por docentes do sexo feminino residentes no estado de Santa Catarina, sendo esses fatores, fundamentais para que seja realizada a análise adequada dos dados.

Gráfico 1 - Distribuição dos respondentes segunda a faixa etária.

50

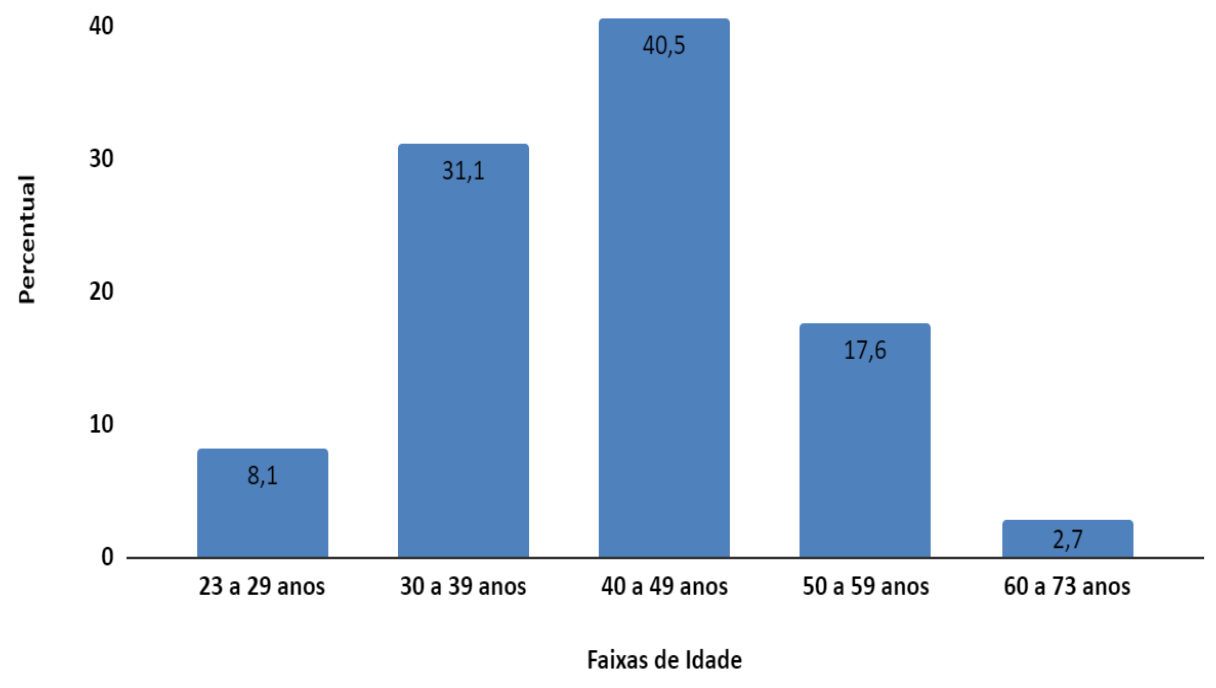

Fonte: elaborado pela autora

Ao analisar a distribuição da faixa etária dentre as mulheres que compõem o quadro docente de respondentes (Gráfico 1), pode-se notar a prevalência da faixa etária das 40 aos 49 anos, evidenciando a presença de mulher com maior nível de experiência e, supostamente, com maior formação. Esta última afirmativa pode ser confirmada através do Gráfico 2, onde 
constatou que $61,4 \%$ das respondentes possuem pós-graduação Stricto Sensu, com destaque ao Mestrado.

Gráfico 2 - Distribuição dos respondentes segunda a formação.

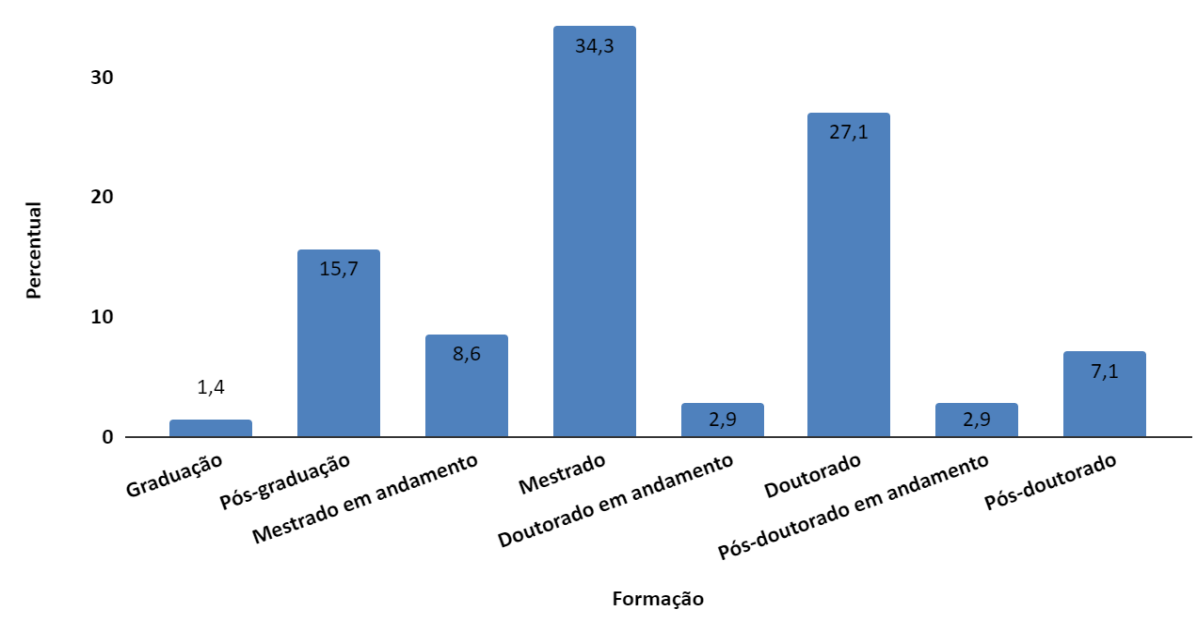

Fonte: elaborado pela autora

Já, o Gráfico 3 salienta a distribuição equiparada na atuação em IES do tipo pública e particular, sendo que a primeira se destaca com presença de $11,5 \%$ a mais das docentes na rede pública. Nesse sentido, pode-se levantar uma hipótese, cuja confirmação demanda mais uma série de pesquisas quantitativas e qualitativas. Como o ingresso em universidades públicas se faz através de concurso público, esse processo seletivo permite o acesso a emprego ou cargo público, de modo amplo e democrático, pode-se deduzir que há um maior acesso à docência universitária por parte das mulheres quando a seleção se faz de forma imparcial e isonômica.

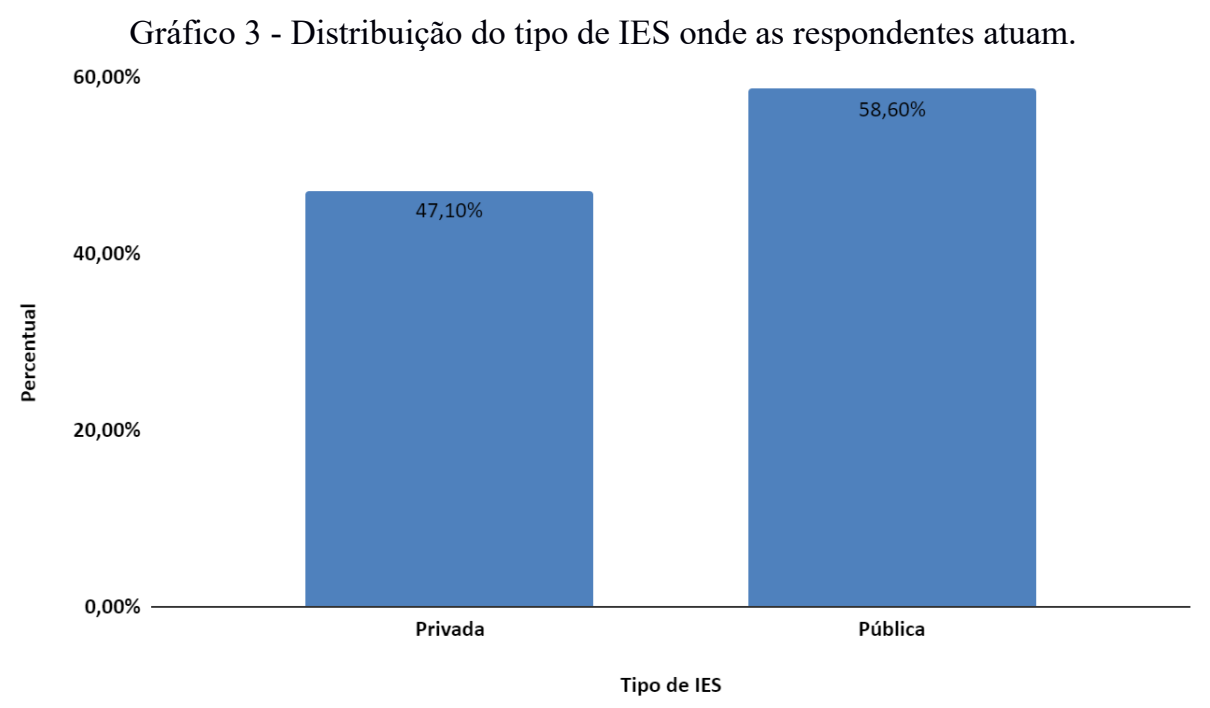

Fonte: elaborado pela autora 


\section{Votume 3 - Número 3

O Gráfico 4 ressalta os desafios a serem superados pelas docentes no ensino superior, sendo que os principais estão atrelados à progressão na carreira e remuneração. Pode-se notar, também, que logo em seguida, aparecem questões relativas ao excesso de serviço e de burocracia, já que grande parte das universidades não incluem na remuneração dos professores o tempo que estes despendem com questões administrativas e atividades extraclasses. Como consequência desse fator, lista-se como quarto desafio a ser superado: a carga excessiva de trabalho. Nesse sentido, coube estipular a relação entre a atuação das docentes em mais de uma universidade e os principais problemas relativos à docência (Tabela 1) e assim notou-se que, apesar da similaridade de identificação com os problemas, aqueles que atuam em mais de uma instituição - 26,7\% das respondentes, apresentaram mais informações com a alta demanda e a falta de tempo livre para família e lazer.

Gráfico 4 - Grau de concordância das respondentes frente aos maiores desafios enfrentados como docentes no ensino superior

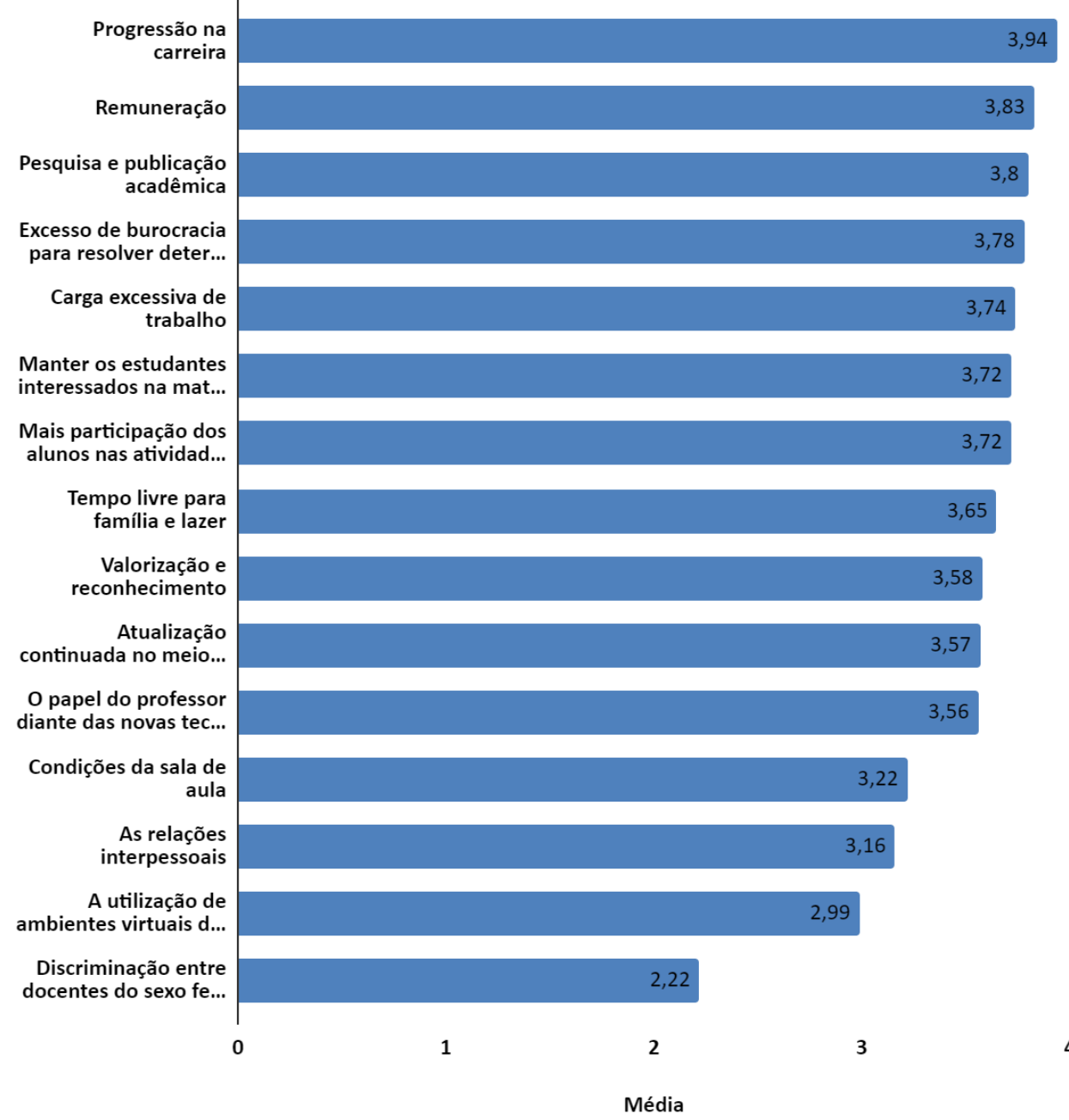

Fonte: elaborado pela autora 


\section{Volume 3 - Número 3

Tabela 1 - Cruzamento entre os principais desafios a serem superados pelas docentes universitárias e a atuação em mais de uma instituição de ensino.

\begin{tabular}{|c|c|c|c|c|}
\hline & \multicolumn{4}{|c|}{$\begin{array}{l}\text { Trabalha em mais de uma instituição } \\
\text { no momento? }\end{array}$} \\
\hline & \multicolumn{2}{|c|}{ Sim } & \multicolumn{2}{|c|}{ Não } \\
\hline & Média & $\begin{array}{l}\text { Desvio- } \\
\text { Padrão }\end{array}$ & Média & $\begin{array}{l}\text { Desvio- } \\
\text { Padrão }\end{array}$ \\
\hline carga excessiva de trabalho & 4,00 & 0,973 & 3,66 & 1,277 \\
\hline tempo livre para família e lazer & 3,90 & 1,071 & 3,57 & 1,087 \\
\hline a utilização de ambientes virtuais de ensino & 2,80 & 0,951 & 3,05 & 1,189 \\
\hline mais participação dos alunos nas atividades propostas & 3,65 & 1,089 & 3,74 & 1,153 \\
\hline discriminação entre docentes do sexo feminino e masculino & 1,70 & 0,923 & 2,39 & 1,295 \\
\hline remuneração & 3,70 & 1,129 & 3,87 & 1,056 \\
\hline condições da sala de aula & 3,25 & 1,070 & 3,21 & 1,142 \\
\hline valorização e reconhecimento & 3,40 & 0,995 & 3,64 & 1,017 \\
\hline as relações interpessoais & 3,30 & 0,979 & 3,11 & 1,199 \\
\hline pesquisa e publicação acadêmica & 3,70 & 0,979 & 3,84 & 0,986 \\
\hline manter os estudantes interessados na matéria & 3,75 & 0,786 & 3,70 & 1,131 \\
\hline o papel do professor diante das novas tecnologias & 3,75 & 0,910 & 3,49 & 1,149 \\
\hline progressão na carreira & 4,00 & 1,124 & 3,92 & 1,005 \\
\hline atualização continuada no meio acadêmico & 3,80 & 0,834 & 3,49 & 1,206 \\
\hline excesso de burocracia para resolver determinados assuntos & 3,60 & 0,883 & 3,84 & 1,200 \\
\hline
\end{tabular}

Fonte: SPSS 21.

Outro desafio relativo à discriminação entre as docentes do sexo feminino apresentar o menor percentual de relevância dentre os outros levantados. Apesar do relato dessa questão entre as respondentes, os problemas que, atualmente, se colocam como inerentes à atuação docente, independente do gênero, obtiveram mais preponderância. Esse ponto pode ser reforçado no relato descritivo das docentes dentro do questionário, cuja principal impugnação está atrelada à baixa valorização dos professores, tanto por parte da instituição, quanto pela sociedade como um todo.

\section{Considerações finais}

Através do referencial teórico, pode-se compreender a trajetória da atuação feminina na atividade docente, principalmente, a partir da década de 1980, período em que os estudos referentes à educação passaram a abordar também a relação entre gênero e docência. Assim, observou-se que, até o século XIX, a sociedade era marcada pela supressão do gênero feminino, cuja atuação se limitava às práticas domésticas e maternais. Mas, com a Revolução Industrial desencadeou-se uma série de mudanças no perfil do mercado de trabalho, as quais trazem consequências até os dias atuais. Assim, a inserção das mulheres no campo educacional se fez 


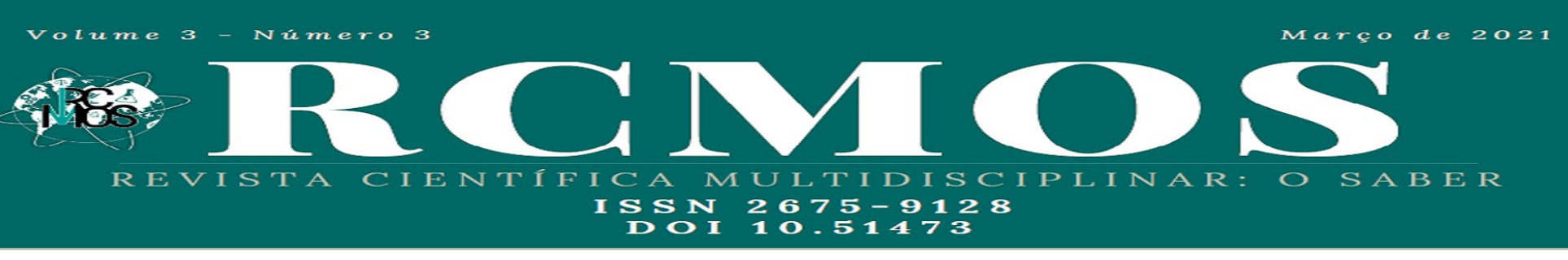

GIL, A. C. Métodos e técnicas de pesquisa social. 6. ed. São Paulo: Atlas, 2008.

LIMA, M. M. L. Magistério e condição feminina. In: COSTA, A. A.; ALVES, I. (Org.)

Ritos, mitos e fatos: mulher e gênero na Bahia. Salvador: NEIM/UFBA, 1997. p. 121-134.

LOURO, G. L. Gênero, sexualidade e educação: uma perspectiva pós estruturalista. 10. ed. Petrópolis, RJ: Vozes, 2008.

MARIUSSI, M. I.; GISI, M. L.; EYNG, A. M. A Escola como Espaço para Efetivação dos Direitos Humanos. Revista Brasileira Educação Especial [online], v. 22, n. 3, p. 443-454, 2016. Disponível em: http://dx.doi.org/10.1590/S1413-65382216000300010. Acesso em: 05 out. 2019.

PEREIRA, L.; ANJOS, D. O professor do ensino superior: perfil, desafios e trajetórias de formação. Seminário Internacional de Educação Superior: Formação e Conhecimento, [s. 1.], ano 2014, v. 1, n. 22, p. 18-29, 2014. Disponível em: https://www.ea2.unicamp.br/mdocsposts/o-professor-do-ensino-superior-perfil-desafios-e-trajetorias-de-formacao/. Acesso em: 9 out. 2019.

ROSEMBERG, F. Educação formal, mulher e gênero no Brasil contemporâneo. Revista Estudos Femininos, v. 9, n. 2, p. 515-540, 2001. Disponível em:

http://dx.doi.o/10.1590/S0104-026X2001000200011. Acesso em: 05 out. 2019.

PINTO, C. R. J. Uma história do feminismo no Brasil. São Paulo: Fundação Perseu Abramo, Coleção História do Povo Brasileiro. 2003.

SOARES, V. Movimento de mulheres e feminismo: evolução e novas tendências. In: Revista Estudos feministas. Rio de Janeiro, 1994. 